NATIONAL FORESTS AND PUBLIC LANDS OF NEVADA ENHANCEMENT ACT OF 1987 AND THE NEVADA-FLORIDA LAND EXCHANGE AUTHORIZATION ACT OF 1987

\title{
HEARING
}

NOV +2 isG

BEFORE THE

SUBCOMMITTEE ON PUBLIC LANDS, NATIONAL PARKS AND FORESTS

OF THE

COMMITTEE ON

ENERGY AND NATURAL RESOURCES

UNITED STATES SENATE

ONE HUNDREDTH CONGRESS

FIRST SESSION

ON

S. 59

A BILL ENTITLED THE "NATIONAL FORESTS AND PUBLIC LANDS OF NEVADA ENHANCEMENT ACT OF 1987"

\section{S. 854}

ENTITLED THE “NEVADA-FLORIDA LAND EXCHANGE AUTHORIZATION ACT OF 1987"

JUNE 30, 1987

-MILY GEPUSTTORY.

Gers SHIPPING LIST\# $87.642 . P$

Printed for the use of the

Committee on Energy and Natural Resources 


\section{Bostom Antion L L}

Boston, ww Uel16 

CHANGE AUTHORIZATION ACT OF 1987

\section{HEARING}

BEFORE THE

SUBCOMMITTEE ON PUBLIC LANDS, NATIONAL PARKS AND FORESTS

OF THE

\section{COMMITTEE ON}

\section{ENERGY AND NATURAL RESOURCES \\ UNITED STATES SENATE}

ONE HUNDREDTH CONGRESS

FIRST SESSION

$\mathrm{ON}$

S. 59

A BILL ENTITLED THE "NATIONAL FORESTS AND PUBLIC LANDS OF NEVADA ENHANCEMENT ACT OF 1987"

\section{S. 854}

ENTITLED THE “NEVADA-FLORIDA LAND EXCHANGE AUTHORIZATION ACT OF 1987"

JUNE 30,1987

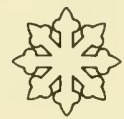

Printed for the use of the

Committee on Energy and Natural Resources

U.S. GOVERNMENT PRINTING OFFICE 


\section{COMMITTEE ON ENERGY AND NATURAL RESOURCES}

\section{J. BENNETT JOHNSTON, Louisiana, Chairman}

DALE BUMPERS, Arkansas WENDELL H. FORD, Kentucky HOWARD M. METZENBAUM, Ohio JOHN MELCHER, Montana BILL BRADLEY, New Jersey JEFF BINGAMAN, New Mexico TIMOTHY E. WIRTH, Colorado WYCHE FOWLER, JR., Georgia KENT CONRAD, North Dakota
JAMES A. MCCLURE, Idaho MARK O. HATFIELD, Oregon LOWELL P. WEICKER, JR., Connecticut PETE V. DOMENICI, New Mexico MALCOLM WALLOP, Wyoming FRANK H. MURKOWSKI, Alaska DON NICKLES, Oklahoma CHIC HECHT, Nevada DANIEL J. EVANS, Washington

DARYl H. OWEN, Staff Director

D. Michael Harvey, Chief Counsel

Frank M. Cushing, Staff Director for the Minority Gary G. Elusworth, Chief Counsel for the Minority

\section{Subcommittee on Public Lands, National Parks and Forests}

DALE BUMPERS, Arkansas, Chairman JEFF BINGAMAN, New Mexico, Vice Chairman

JOHN MELCHER, Montana

BILL BRADLEY, New Jersey

TIMOTHY E. WIRTH, Colorado

WYCHE FOWLER, JR., Georgia

KENT CONRAD, North Dakota
MALCOLM WALLOP, Wyoming LOWELL P. WEICKER, JR., Connecticut MARK O. HATFIELD, Oregon PETE V. DOMENICI, New Mexico FRANK H. MURKOWSKI, Alaska CHIC HECHT, Nevada

J. Bennett Johnston and James A. McClure are Ex Officio Members of the Subcommittee

Thomas B. Williams, Senior Professional Staff Member Beth Norcross, Professional Staff Member 


\section{CONTENTS}

S. 59

S. 854

\section{STATEMENTS}

Bechtel, Dennis A., coordinator, Clark County Department of Comprehensive Planning, Clark County, NV....

Bilbray, Hon. James H., a U.S. Representative from the State of Nevada....... 40, 203

Bok, Erik, Federal legislative representative, Los Angeles Department of Water and Power, Los Angeles, CA.

Bryan, Hon. Richard H., Governor, State of Nevada

Bumpers, Hon. Dale, a U.S. Senator from the State of Arkansas.

Burford, Robert F., Director, Bureau of Land Management, Department of the Interior.

Burge, Betty, Desert Tortoise Council, Las Vegas, NV.

Callison, Charles H., public lands consultant, Natural Resources Defense Council

Cavanaugh, Wallace J., Crown Development \& Mining Co., Wellington, NV ....

Clark, Ralph E., executive vice president and general manager, Aerojet Nevada, North Las Vegas, NV

Fascell, Hon. Dante B., a U.S. Representative from the State of Florida...............

Harris, Gail, Ad Hoc Committee on Aerojet, Las Vegas, NV

Hecht, Hon. Chic, a U.S. Senator from the State of Nevada.

Horn, William P., Assistant Secretary for Fish and Wildlife and Parks, Department of the Interior .

Hornbeck, David A., Toiyabe Chapter of the Sierra Club, Reno, NV

Laxalt, Hon. Paul, a former U.S. Senator from the State of Nevada.

Leonard, George M., Associate Chief, Forest Service, Department of Agriculture

Perry-Jones, Jean, Evergreen Alliance, Mount Charleston, NV

Reid, Hon. Harry, a U.S. Senator from the State of Nevada

Smith, Lenard, commissioner, Lincoln County, Pioche, NV

Vucanovich, Hon. Barbara F., a U.S. Representative from the State of Nevada

Wadsworth, Shelley, executive secretary, Economic Development Task Force, Lincoln County, NV

Wagner, Sue, Nevada State senator.

Watson, Charles S., Jr., director, Nevada Outdoor Recreation Association, Inc., Carson City, NV

Wilson, Thomas R.C., cochairman, National Forest Task Force of Nevada.........

Wright, Fred, legislative and issues representative, Nevada Wildlife Federation, Inc., Reno, NV. 



\title{
NATIONAL FORESTS AND PUBLIC LANDS OF NEVADA ENHANCEMENT ACT OF 1987 AND THE NEVADA-FLORIDA LAND EXCHANGE AUTHOR- IZATION ACT OF 1987
}

TUESDAY, JUNE 30, 1987

\author{
U.S. Senate, \\ Subcommittee on Public Lands, \\ National Parks and Forests, \\ Committee on ENERgy and Natural Resources, \\ Washington, $D C$.
}

The subcommittee met, pursuant to notice, at 2:05 p.m., in room SD-366, Dirksen Senate Office Building, Hon. Chic Hecht, presiding.

Senator Неснт. Senator Bumpers had hoped to be here. $\mathrm{He}$ might be here a little bit later. I know a lot of people have come a long way. So, in the interest of time, we are going to start right away, and if Senator Bumpers comes in, he will take over the Chair.

[The prepared statement of Senator Bumpers and the texts of S. 59 and S. 854 follow:] 
STATEMENT BY THE HONORABLE DALE BUMPERS

The purpose of the hearing this afternoon is to receive testimony on two measures currently pending before the Subcomittee. The measures are:

S. 59 - the "National Forest and Public Lands of Nevada Act of $1987^{\prime \prime}$; and

S. 854 - the "Nevada - Florida Land Exchange Authorization Act of 1987".

Each of these measures is cosponsored by the two Nevada Senators, Senators Hecht and Reid, and there are companion measures pending in the House of Representatives. At this point I will place copies of these bills in the Hearing Record.

A version of S. 59 - the so-called Nevada Interchange bill passed the House last year. Primarily because of a dispute over language regarding federal reserved water rights, that mesure did not pass the senate. That issue is still with us in this bill and it will have to be resolved before this measure can be enacted. In addition, I am particularly interested in how this measure will effect the management of roadless areas administered by the BLY and the Forest Service. 
The Aerojet land exchange embodied in S. 854 has proven to be fairly controversial. While the exchange is supported by the entire Nevada congressional delegation as well as the Governor, a number of conservation groups will present testimony today in opposition to this proposed exchange. While I generally favor land exchanges, I want to be sure that the United States receives a fair deal and that the public interest is protected. I plan to examine this particular proposal closely to insure that these elements are present. 
100TH CONGRESS

1ST SESSION

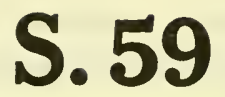

A bill entitled the "National Forests and Public Lands of Nevada Enhancement Act of 1987".

\section{IN THE SENATE OF THE UNITED STATES}

JANUARY 6, 1987

Mr. Hecht (for himself and Mr. Reid) introduced the following bill; which was read twice and referred to the Committee on Energy and Natural Resources

\section{A BILL}

A bill entitled the "National Forests and Public Lands of Nevada Enhancement Act of 1987".

Be it enacted by the Senate and House of Representa-

2 tives of the United States of America in Congress assembled,

3 SECTION 1. SHORT TITLE.

4 This Act may be cited as the "National Forests and

5 Public Lands of Nevada Enhancement Act of 1987."

6 SEC. 2. FINDINGS AND PURPOSES.

(a) Findings. - The Congress finds that-

(1) the public lands transferred by this Act contain

9 valuable natural resources (such as watershed, range,

10 outdoor recreation and wildlife habitat) which will be 
1 enhanced by the professional, multiple-use management 2 of the Forest Service; and that certain national forest 3 lands would be enhanced by the professional multiple4 use management of the Bureau of Land Management;

(2) the public which uses these natural resources will be benefited by such adjustments in management;

(3) the public lands transferred by this Act to the 8 Forest Service are adjacent to existing national forests 9 and, in many cases, are part of the same watersheds 10 and mountain ranges, and placing the management of 11 these lands under the administration of one agency, the 12 Forest Service, will improve efficiency and be cost ef13 fective; that similar efficiency and effectiveness will 14 result from transfer of certain national forest lands to 15 the Bureau of Land Management and;

16 (4) there is a consensus in Nevada that these 17 lands should be added to the national forests and that 18 some national forest lands should be transferred to the 19 Bureau of Land Management for management.

20 (b) Purposes. - The purposes of this Act are-

21 (1) to transfer to the Forest Service, United 22 States Department of Agriculture, certain public lands 23 in Nevada currently administered by the Bureau of 24 Land Management, United States Department of the 25 Interior. These public lands are contiguous to the 
1 Toiyabe and Inyo National Forests and will become

2 National Forest System lands; and

(2) to transfer to the Bureau of Land Management, United States Department of the Interior, certain lands in Nevada currently administered by the

6 Forest Service, United States Department of Agriculture. These lands are contiguous to other public lands and will be managed as such.

9 SEC. 3. DEFINITIONS.

10 As used in this Act-

11 (a) the term "public lands" means the lands ad-

12 ministered by the Bureau of Land Management, United

13 States Department of the Interior, as defined in section

14 103(3) of the Federal Land Policy and Management

15 Act of 1976 (43 U.S.C. 1701(e)); and

16 (b) the term "National Forest lands" or "National 17 Forest System lands" means the lands administered by 18 the Forest Service, United States Department of Agri19 culture, as defined in section 11 of the Forest and

20 Rangeland Renewable Resources Planning Act of 1974 21 (16 U.S.C. 1609(a)).

22 SEC. 4. TRANSFER OF LANDS.

(a) Transfer of Public Lands to the Forest

24 Service.-Effective one hundred and eighty days after the

25 enactment of this Act, the approximately five hundred eleven 
1 thousand acres of public lands designated for inclusion in the

2 National Forest System on two maps entitled "Nevada Inter-

3 change-A" and "Nevada Interchange-B" and dated Janu-

4 ary 1987, are hereby transferred to the Secretary of Agricul-

5 ture and shall become part of the Toiyabe National Forest or

6 the Inyo National Forest.

(b) Boundaries of Toiyabe and Inyo NaTiONAL Forests.-

(1) The boundaries of the Toiyabe National Forest

10 and the Inyo National Forest are hereby modified to

11 reflect the transfer of lands under subsection (a).

(2) For the purpose of section 7 of the Land and

13 Water Conservation Fund Act of 1965 (16 U.S.C. 14 4601-9), the boundaries of the Toiyabe National

15 Forest and the Inyo National Forest, as modified by 16 this subsection, shall be treated as if they were the 17 boundaries of those National Forests as of January 1, 181965.

(c) Transfer of Forest Service Lands to the

20 Bureau of Land Management.-Effective one hundred

21 and eighty days after the enactment of this Act, the approxi-

22 mately twenty three thousand acres of national forest lands

23 identified for management by the Bureau of Land Manage-

24 ment on a map entitled "Nevada Interchange-A" and dated 
1 January 1987, are hereby transferred to the Secretary of the 2 Interior.

3 (d) MAPS.-The maps referred to in subsection (a) and 4 subsection (c) shall be on file and available for public inspec-

5 tion, in the offices of the Chief, Forest Service, Department 6 of Agriculture, and the Director, Bureau of Land Manage-

7 ment, Department of the Interior. The Secretaries of Agri-

8 culture and the Interior may make changes to the maps to

9 correct technical errors.

10 (e) Effective one hundred and eighty days after enact-

11 ment of this Act, lands transferred by subsection (a) of this

12 section to the jurisdiction of the Secretary of Agriculture

13 shall be subject to the planning requirements of section 6 of

14 the Forest and Rangeland Renewable Resources Planning

15 Act of 1974, and lands transferred by subsection (c) of this

16 section to the jurisdiction of the Secretary of the Interior

17 shall be subject to the planning requirements of the Federal

18 Land Policy and Management Act of 1976. All transferred

19 lands shall continue to be managed in accordance with plans

20 in effect on the date of enactment of this Act until considered

21 in plans developed under applicable provisions of law. If no

22 plans are in effect on the date of enactment of this Act, the

23 respective transferred lands shall be managed in a manner

24 consistent with other national forest or public lands, as the

25 case may be, in the vicinity until a plan is developed under 
1 applicable provisions of law. Nothing in this Act shall of itself

2 require the amendment or revision of the existing plans gov-

3 erning public lands or national forest affected by the addition

4 of or deletion of lands transferred by this Act.

5 SEC. 5. WILDERNESS SUITABILITY.

6 (a) Bureau of Land Management Study 7 Areas.-Any area or portion thereof designated as a

8 Bureau of Land Management Wilderness Study Area (Mount

9 Stirling, NV-050-401; LaMadre Mountains, NV-050-412)

10 on the maps referred to in section 3(a) which is made a part

11 of the National Forest System by this Act shall be managed

12 by the Secretary of Agriculture in accordance with the provi-

13 sions of section 603(c) of the Federal Land Policy and Man-

14 agement Act of 1976 (43 U.S.C. 1782) until Congress desig-

15 nates that area as wilderness or releases it from further wil-

16 derness consideration.

(b) Roadless areas not Recommended as Wil-

18 DERNESS.-Any roadless area or portion thereof which is

19 made a part of the National Forest System by this Act and

20 which has been considered but not recommended for designa-

21 tion as wilderness pursuant to section 202 of the Federal

22 Land Policy and Management Act of 1976 (43 U.S.C. 1712)

23 shall be deemed to have been adequately considered for wil-

24 derness for the purposes of the initial land management plans

25 hereafter required for such lands by section 6 of the Forest 
1 and Rangeland Renewable Resources Planning Act of 1974

2 (16 U.S.C. 1604). The Secretary of Agriculture shall not be

3 required to manage such area to preserve wilderness values

4 or to review the wilderness option before the revision of such

5 plans, but the Secretary shall review the wilderness option

6 for such area when such plans are revised.

7 (c) Any roadless area, or portion thereof on national

8 forest lands recommended by the Secretary of Agriculture for

9 wilderness which will be transferred to the jurisdiction of the

10 Secretary of the Interior pursuant to section 3(c) of this Act,

11 shall be managed by the Secretary of the Interior in accord-

12 ance with the provisions of section 603(c) of the Federal

13 Land Policy Management Act, or other specific statutory di-

14 rection.

15 (d) No Addition to the National Wilderness

16 Preservation System.-Nothing in the Act shall be con-

17 strued to add lands to the National Wilderness Preservation

18 System.

19 SEC. 6. MANAGEMENT OF MINERAL RESOURCES.

20 Nothing in this Act shall be construed to change the

21 laws governing the management of mineral resources.

22 SEC. 7. ADMINISTRATION OF RECEIPTS.

23 The acreage added to the Toiyabe and Inyo National

24 Forests in the State of Nevada by this Act shall not be count-

25 ed in determining the distribution of the Twenty-Five Per- 
1 cent Fund between the States of California and Nevada

2 under the Act of May 23, 1908, as amended: Provided, how-

3 ever, That the acreage added to these forests shall be counted

4 in the distribution of the Twenty-Five Percent Fund among

5 the affected counties in Nevada.

6 SEC. 8. WATER RIGHTS.

7 (a) Prior Existing Water Rights.-Nothing in this

8 Act shall be construed to expand or diminish any water right

9 of the United States under State or Federal law which the

10 United States had, or may be determined to have had by

11 purchase, reservation, or otherwise, before the date of enact-

12 ment of this Act.

13 (b) No Federal Reserved Water Rights by

14 Reason of Transfer.-The designation and withdrawal

15 of newly established national forest lands by this Act shall

16 not create any reserved water rights in the United States by

17 reason of this Act with respect to those lands.

18 (c) Right to Acquire and Dispose of Water

19 Rights. - Nothing in this Act shall affect the right of the

20 United States or of any person to acquire or dispose of water

21 or water rights under applicable law.

22 SEC. 9. VALID EXISTING RIGHTS.

23 (a) Nothing in this Act shall affect valid existing rights 24 of any person under any : authority of law as of the date of 25 enactment of this Act. 
1 (b) Authorizations to use lands transferred by this Act

2 which were issued prior to the date of transfer shall remain

3 subject to the laws and regulations under which they were

4 issued: Provided, That such laws and regulations will be ex-

5 ercised by the Secretary to whom jurisdiction over affected

6 lands has been transferred by this Act. However, renewals

7 and extensions shall be subject to the laws and regulations

8 pertaining to the agency which has jurisdiction over the land

9 at the time of renewal or extension. The change of adminis-

10 trative jurisdiction resulting from the enactment of this Act

11 shall not in itself constitute a basis for denying or approving

12 the renewal or reissuance of any such authorization.

13 SEC. 10. ADMINISTRATIVE APPEALS.

14 With respect to the lands transferred by section 3 , any

15 formal administrative appeal, adjudication, or review pending

16 on the date of transfer of jurisdiction under this Act shall be

17 completed by the Secretary of the Department in which it

18 was initiated except that the Secretary of the Department

19 having jurisdiction over the land pursuant to this Act may

20 exercise final administrative review.

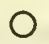


Entitled the "Nevada-Florida Land Exchange Authorization Act of 1987".

\section{IN THE SENATE OF THE UNITED STATES}

MarCh 26 (legislative day, Мarch 24), 1987

Mr. Heснт (for himself and Mr. ReID) introduced the following bill; which was read twice and referred to the Committee on Energy and Natural Resources

\section{A BILL}

Entitled the "Nevada-Florida Land Exchange Authorization Act of 1987'.

1 Be it enacted by the Senate and House of Representa-

2 tives of the United States of America in Congress assembled,

3 SECTION 1. SHORT TITLE.

4 This Act may be cited as the "Nevada-Florida Land

5 Exchange Authorization Act of 1987".

6 SEC. 2. BASIS OF EXCHANGE.

(a) Authorization of Exchange.-Notwithstand-

8 ing any other provision of law, and subject to valid existing

9 rights, the Secretary of the Interior (hereinafter referred to as

10 the Secretary) is authorized and directed to exchange ap-

11 proximately fifty-one thousand seven hundred and ten acres 
1 of public lands and interests in lands and reserved mineral

2 estate in the State of Nevada, as generally depicted upon

3 maps entitled "Public Domain Lands to be Exchanged to

4 Aerojet-General Corporation, Clark and Lincoln Counties,

5 Nevada" and "Public Domain Lands to be Exchanged to

6 Aerojet-General Corporation, Mineral County, Nevada" both

7 dated February 1987, and available for public inspection in

8 the Office of the Secretary and the Nevada State Office of

9 the Bureau of Land Management, for approximately four

10 thousand six hundred and sixty acres of private lands in Dade

11 County, Florida, as generally depicted upon a map entitled

12 "Aerojet-General Corporation Lands to be Exchanged to

13 United States Fish and Wildlife Service, Dade County, Flori-

14 da," dated February 1987, and available for inspection in the

15 Office of the Secretary.

16 (b)(1) Legal Description.-Within six months after

17 the enactment of this Act, the Secretary shall file legal de-

18 scriptions of the lands indicated on the maps referenced in

19 subsection (a) with the Committee on Interior and Insular

20 Affairs of the United States House of Representatives, and

21 with the Committee on Energy and Natural Resources of the

22 United States Senate. Such legal descriptions shall have the

23 same force and effect as if included in this Act, except that

24 the Secretary may correct clerical and typographical errors

25 in such legal descriptions and in the maps referred to in sub-.. 
1 section (a). The legal descriptions shall be on file and avail-

2 able for public inspection in the offices of the Bureau of Land

3 Management, Department of the Interior.

4

(2) Interim Conveyance of Unsurveyed Lands.-

5 Lands to be conveyed pursuant to this Act, as indicated on

6 the maps referenced in subsection (a), which have not been

7 surveyed, or for which any boundary needs to be surveyed,

8 shall be conveyed by an "interim conveyance" to the party

9 entitled to the lands. The force and effect of such an interim

10 conveyance shall be to convey to and vest in the recipient

11 exactly the same right, title and interest in and to the lands

12 as the recipient would have received had he been issued a

13 patent by the United States. Upon survey of lands covered by

14 an interim conveyance a patent thereto shall be issued to the

15 recipient. The boundaries of the lands as defined and con-

16 veyed by the interim conveyance, in accord with the maps

17 referenced in subsection (a), shall not be altered, but may be

18 redescribed in the patent, where necessary, in reference to

19 the plat of survey.

20 (c) Exchange Requirements.-Notwithstanding any

21 other provision of law, the exchange authorized and directed

22 herein shall be performed in accordance with the terms of

23 this Act and the draft exchange agreement entitled Land Ex-

24 change Agreement between Aerojet-General Corporation

25 and the United States of America dated The 
4

1 Secretary shall execute such agreement and implement this

2 exchange within ninety days of enactment of this Act.

3 SEC. 3. TRANSFER OF FLORIDA LANDS TO WATER MANAGEMENT DISTRICT.

(a) Sale to South Florida Water Management

6 District.-Notwithstanding any other provision of law, the

7 Secretary of the Interior is authorized and directed to sell by

8 issuance of a quitclaim deed the lands acquired in accordance

9 with the provisions of section 2(a) to the South Florida Water

10 Management District at such price as may be mutually

11 agreed upon by the Secretary and the District: Provided,

12 That such price shall not be less than fair market value.

13 (b) Management of Property.-Pending the com-

14 pletion of the sale authorized in subsection (a), the Secretary

15 is authorized to enter into a Memorandum of Agreement with

16 the South Florida Water Management District providing for

17 management of the property by the District in accordance

18 with the rules and regulations applicable to the lands owned

19 by the District.

20 SEC. 4. USE OF FUNDS RECEIVED.

21 (a) Use of Funds Received by United States.-

22 Notwithstanding any other provision of law, any funds re-

23 ceived by the United States from the sale of lands authorized

24 by section 3(a) shall be deposited in the "Contributed Fund

25 Account" of the United States Fish and Wildlife Service, and 
5

1 shall be utilized for the purchase of additional non-publicly

2 owned lands at existing elements of the National Wildlife

3 Refuge System in the State of Florida. Such funds shall be

4 available for obligation without appropriation.

5 (b) Notice to Congress.-The Secretary shall notify 6 the Committee on Appropriations of the Senate, and the

7 Committee on Appropriations of the House of Representa8 tives, of any proposal to obligate funds received in accord-

9 ance with the provisions of subsection (a) at least sixty days

10 prior to the actual obligation of such funds. 


\section{OPENING STATEMENT OF HON. CHIC HECHT, A U.S. SENATOR FROM THE STATE OF NEVADA}

Senator Hecht. My statement was for Senator Bumpers, and I want to read it. But I want you to know that I am not talking to myself. I am talking to Senator Bumpers.

Mr. Chairman, I commend you for holding these hearings today on two pieces of legislation that will greatly benefit the citizens of Nevada. S. 59 and S. 854 both have the strong support of the entire Nevada delegation.

S. 59 transfers approximately 511,000 acres of Nevada's BLM land to the Forest Service, and approximately 23,000 acres of land from the Forest Service to the BLM.

S. 59 is very similar to last year's Nevada Interchange Bill, S. 2698 .

The advantage of S. 59 is that it will streamline and improve public land management in Nevada, and also ultimately make management less expensive for the taxpayers. The Interchange Bill will smooth out some irregular boundaries between the Forest Service and the BLM, but no sudden changes are anticipated in the daily, on-the-ground management of any of these lands after they are transferred.

S. 854 will accomplish a land exchange between the U.S. Fish and Wildlife Service and Aerojet General Corporation. The Federal Government will get several thousand acres of Aerojet-owned lands in Florida, which will then be sold to the State of Florida.

The proceeds will be used to buy additional land for the National Wildlife Refuge System in Florida. In turn, Aerojet will receive a large tract of BLM land in southern Nevada.

S. 854 allows everyone to win. The Federal Government wins, the State of Florida wins, the State of Nevada wins, and Aerojet General wins. Perhaps most importantly of all, our Nation's ever-shrinking and irreplaceable wetland resources and the wildlife they support come out a definite winner.

Mr. Chairman, many Nevadans have been working hard for more than two years on these bills. I am hopeful that this Committee will act quickly and report out both bills.

Mr. Chairman, I have statements on S. 59 that I would like inserted into the record. They are from Governor Bryan of Nevada and two co-chairmen of the National Forest Task Force of Nevada, Spike Wilson and Sue Wagner.

Regarding S. 854, I would like to insert into the record a letter from Governor Bryan and a resolution from the Nevada legislature, both in strong support of this bill. I would also submit the Governor's written testimony on S. 854 into the record. Statements received by the subcommittee from Congressman Bilbray, Congressman Fascell, and former U.S. Senator Paul Laxalt will also be placed in the record at this point.

[The material referred to follows:] 


\section{STATEMENT OF}

THE HONORABLE RICHARD H. BRYAN

GOVERNOR OF NEVADA

submitted to the

SUBCOMITTEE ON PUBLIC LANDS, NATIONAL PARKS AND FORESTS

COMMITTEE ON ENERGY AND NATURAL RESOURCES

UNITED STATES SENATE

on

S. 59 - NATIONAL FORESTS AND PUBLIC LANDS OF NEVADA ENHANCEMENT ACT

June 30,1987 


\section{TBSTIMONY BEFORB THE SBNATE COMMTTTEB ON \\ BNEROY AND NATORAL REOURCES \\ SUBCOMMTTTBB ON PUBLIC LANDB, FATIONAL PARKS AND FORBSTS JUNB 30, 1887}

8. 39, National Forests and Publlo Lands of Nevada Enhancement Act of 1987

Mr. Chalrman, members of the committee, Neveda epprecistes the opportunity to enter testlmony today on 8.58 , the National Porests and Publle Lands of Nevada Enhancement Aet of 1987 .

Wo all recall that more then two years ago the Reagan adminlstration unvelled - masalve land interchange propossh Involving more than 35 mallion acres of land natlonwlde. Publle response was swlft and olear. This was too massive shange and was proposed with too little attention to the Impacts on locel communities and private cltizens.

In Nevede, the original land swap proposal would have virtually wiped out our national forats. Navadan rae with one volce in defonse of the national forestsof the state. Ranchers, miners, conservationluts and wildife advocates were united in oppodtion to the transile of more than $80 \%$ of the land managed by the Porent Service to the Bureau of Land Menagement. The rallying cry was to keep the green on the mep of Nevade

In my teotimony on that origtral proposal, given at a public hearing almost exactly two year agr today, I itressed that "the complex neod of the public lands that comprise one third of our natlons's lande cannot be adequately adtressed with a single broad-brush plan dotated from the nattonal leval It was a mistake to start at the top with one national concept map that mandated wholesale transfer of entire reglons, without consideration of special rewource conditons and the impacts on local and regtonal coonomice." However, 1 pledged our cooperation with mare sensible efforts to almplify agoncy boundarte on a state-by-state bests. 
Page 2

The blll before you today ropresents such an elfort. Within a year after tho original federal land swap proposal, Nevedam had reached agreement on a package of sarsible agency boundary adjustments that would enhence public land management while increasing agency efflelency. Introduced last seaston as the National Porest of Nevada Enhencement Act of 1288, It allad for the transfer of some 331,000 aeres of land from the Bureau of Land Menegement to the Forest Service, and epproximately 23,000 acres from the Porest Service to the Burealh It would aimplify boundary lines and consolldate agency holoings. One of its major strengths is the consolidation in Forest Service management of heavlly used recreation lands noar the metropolitan areas of Las Vegas and Reno. As you recall, this bill pased in the House of Representatues, but ald not come to a vote In the senate befare the end of the 99th Congress.

The State of Nevada still strongly supports thit proposal. It achleves the goals the Reagan administration set for Its arifinal lend swup propoads (1) It would Improve service to the publle. (2) It would improve adminintrative eflelency. (3) It would reduce the colt of doing bualnes. This blll ha two Importent additionel bensfltet (1) It was developed by ard has the support of Nevadars (2) It would enhance the management of our land and resources, including sansltive watershed areas, wllalfo habitat, grazing resources, mineral resourees, and Increadngly valuable recreationd opportunities. 
Page 3

You may note that the bul befare you today differs from the 1986 Enhancement Act in one important way. The earlle bull Included the trander to Porest Service furludietion of come lends near the city of Reno on the slopes of Peavine Mountain, and these land hev been deleted from the present bllb Peavine b e derert pak that looms over the dty of Reno and is havily used by olty reatdante sealdne opan Iend far secreatlon. It alo provide veimble watershed foe the dty and it northern

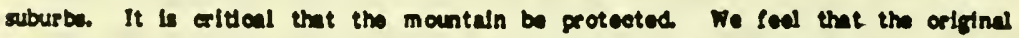
Bnheneement Aot introduced lest yer we cerreot in It eveiuation of these lends, and will continue to suport thair trenser to Pareat serviee menegement.

In summery, end with the amendment dted above, the state of Nevade supports

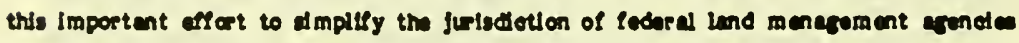

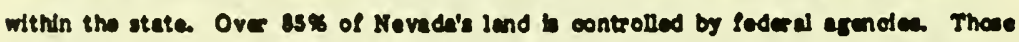
of w wh mut liw and wark with the ledarel peocese reeommend these changw benefleld to both state and naton, and ek sour support 


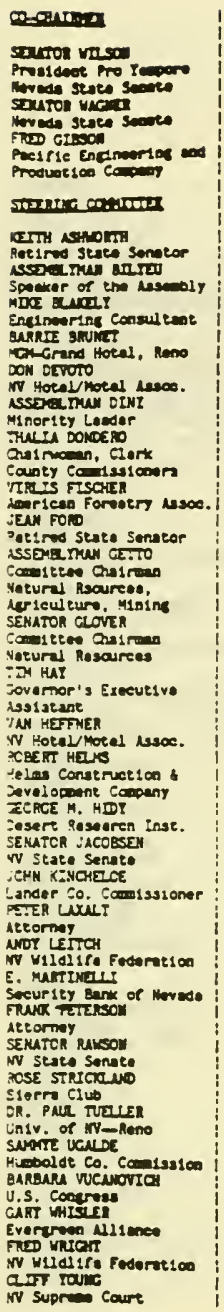

THE NATIONAL FOREST TASK FORCE OF NEVADA

241 Ridge Street

P.O. Box 2670

Reno, Nevada 89505-2670

(702) 322-0635

June 24,1987

\section{Chairman}

Subcommittee on Public Lands

Committee on Energy and Natural Resources clo Senator Chic Hecht

U.S. Senate

Washington, D.C. 20510

Dear Mr. Chairman:

I want to express my thanks for giving Nevadans a change to be heard today on $S$ 59. Because of other commitments and the relatively short notice of this hearing, I cannot be here personally today. But many from Nevada are here in spirit with me and want to express their strong support of $s 59$.

This Bill has the support of thousands throughout Nevada who opposed the declassification and transfer to the BLM of Nevada's national forests as a part of the National Interchange legislation of the 99th Congress. Nevadans instead felt that their national forests should be increased. For that reason, our Congressional Delegation introduced S 2698 and HR 5277 of the 99 th Congress, and have introduced S 59 and HR 267 of this Congress.

S 59 would add to the Humboldt and Toiyabe National Forests somewhat over 500,000 acres of adjacent and abutting land which are national forest in character and would enjoy cost effective management as a part of adjacent national forest holdings.

The appropriateness of this proposed transfer to the national forests was the subject of comprehensive discussion and agreement on January 22, 1986 here in Washington, D.C. by our three Co-Chairmen Fred Gibson, Sue Wagner and myself, James Parker, Assistant Director of the BLM, Max Peterson, Chief of the U.S. Forest Service, and our Congressional Delegation, then Senators Paul Laxalt and Chic Hecht, and Congressman Barbara Vucanovich and Harry Reid. 


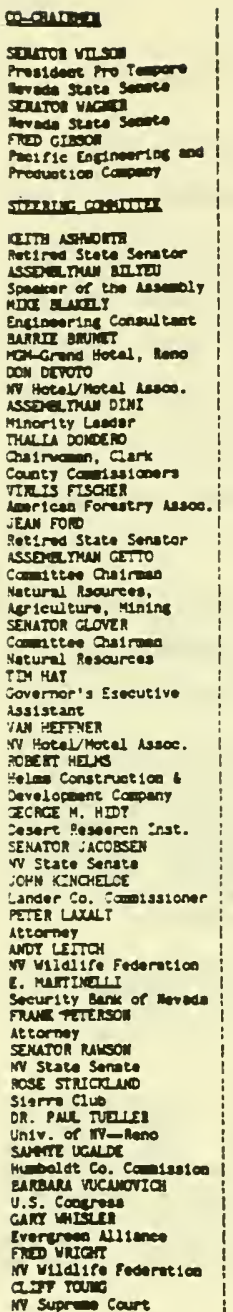

Chairman

Subcomittee on Public Lands

June 24,1987

Page 2

That agreement was represented by $\mathrm{S} 2698$ and $\mathrm{Hr} 5277$ which were introduced by our Delegation in the 99 th Congress. It is today represented by $S 59$ and HR 267, introduced by our Delegation in this 100 th Congress.

I have attached a copy of my testimony given before this subcommittee a year ago on september 19, 1986, which I will not read. Its point is the same, the bill then was substantially the same, and the reasons are the same. The merits of 559 and its reasons are also the same.

Thank you for hearing us today.

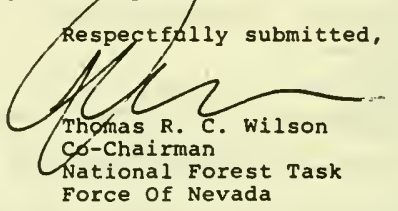

TRCW : gmm

CC: U.S. Senator Harry Reid

U.S. Congresswoman Barbara Vucanovich

U.S. Congressman James Bilbray

Nevada State Senator Sue Wagner

NFTF/13 
THE NATTONAL FOREST TASK FORCE OF NEVADA

241 Ridge Street

P.O. Box 2670

Reno, Nevada 89505-2670

(702) 322-0635

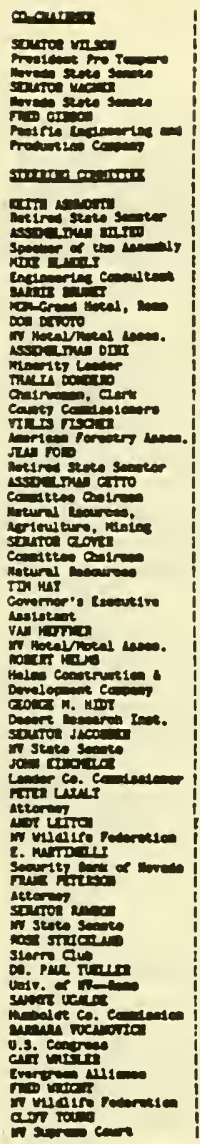

September 19,1986

The Honorable Malcolm Wallop, Chairman

Subcomittee on Public Lands

Committee on Energv and Natural Resources

U.S. Senate

Washington, D.C. 20510

\section{Dear Senator Wallop:}

I would like to submit this letter as the official testimonv of the National Forest Task Force of Nevada at the September 19 Public Hearing on The National Forests of Nevada Enhancement Act (S2698). The Task Force is a bipartisan organization of Nevada leaders from all parts of the state and all walks of life. We formed almost two years ago to save Nevada's national forests, the Toivabe and Humbodt, from elimination bv the BLM/Forest Service land exchange (Interchange). The bill before vour subcommittee, which would add over a half million acres of BLM's public lands to the Toiyabe and Humboldt National Forests, is a positive outarowth of that effort. The Task Force wholeheartedly endorses the National Forests of Nevada Enhancement Act and Lrges its speedy passage.

THE LANDS ADDED WOULD BE CONTIGUOUS

TO THE PRESENT TOIYABE AND NATIONAL FOREST HOLDINGS AND OF THE SAMF, CHARACTER

The proposed lands to be added are approximatelv:

$$
\begin{aligned}
& \text { 15,000 acres along the East slope of } \\
& \text { the Rubv Mountains } \\
& 17,000 \text { acres at Mt. Moriah } \\
& 287,000 \text { acres along the East slope } \\
& \text { of the Sierra Nevadas }
\end{aligned}
$$

192,000 acres in the Sprina Mountain Ranqe, enlarged up to 254,000 if Lovell

Canvon and Mt. Potosi are includer. 
Senator Wallop

September 19,1986

Page 2

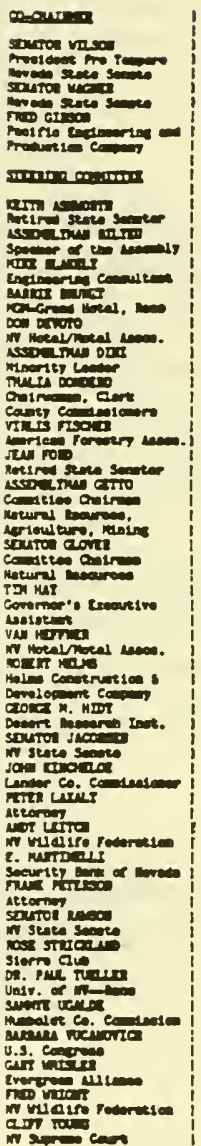

The attached map should be made a part of this record and included in my testimonv.

Each of the parcels abuts either the Toivabe or the Humboldt National Forests and is of the same character and qualit:". Thev should be added to enhance the national forests and for ease of economy and management.

\section{WIDESPREAD POPUIAAR SUPPORT}

The importance of adding these lands to Nevada's national forests first surfaced at the three land exchance public hearings held in Nevada in June, 1985. Almost all testified that they were opposed to anv national forest lands being transferred to the BLM, and many supported contiquous BLM public lands being transferred to the U.S. Forest Service. In Las Vegas for example, petitions with manv siqnatures were submitted asking that all of the PLM holdings in the spring Mountains be classified as national forest.

Thus, the concept behind the Enhancement Act was developed not by government officials but by citizens at the grassroots level. Furthermore, in a bipartisan show of unity, this bill was introduced and is co-sponsored by all four members of Nevada's Congressional Delegation. The four largest newspapers in Nevada, the Las Vegas ReviewJournal, the Las Veaas Sun, the Reno Gazette-Journal and the Nevada Appeal, have endorsed the Fnhancement Act editorially. It is clear that the vast majorit: nf Nevadans would like to see their national forests arow.

\section{INCREASED GOVERNMENT EFFICIENCY}

The acreage to be transferred is comparatively sma? ?. The BLM administers 48.8 million acres in Norara comprising 698 of the state. The Forest Service, witt 5.3 million acres, administers only 88 . Transferring a if million acres of BLM lands to the II.S. Forest Servirs is not a significant change in the administration of $\quad \ldots+\cdots+1$ lands in Nevada. The four areas in the Act which wr." he added to the national forests all abutt existing natir.." 
Senator Wallop

September 19,1986

Page 3

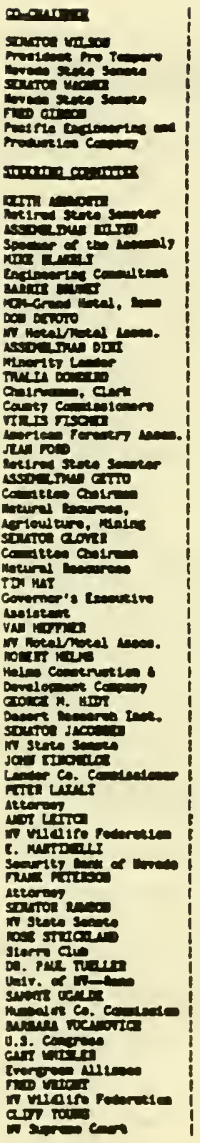

forest lands and are national forest in character. For this reason, qiving them to the U.S. Forest service to administer is more efficient and, in the long run, will save the taxpayer monev. It makes economic sense for these areas to be managed by one agency instead of two.

\section{BENEFITS TO NEVADA}

The National Forests of Nevada Enhancement Act will provide our state with tangible economic and environmental benefits:

1. The natural resources on the transferred lands will benefit from the Forest Service's better funding and professional expertise. Quality resource management is in evervone's best interest.

2. Nevada's largest industry, tourism, qains from having more qreen on the map of Nevada. National Forests attract visitors and enhance a state's imare.

3. The Forest Service has a greater number of revenue sharing programs with state and countv agencies than the BLM. Local onvernments in Nevada will benefit financiallv with additional national forest acreage.

\section{THE IMPORTANCE OF THE SPRING MOUNTAIN ADDITIONS}

The maiority of Nevadans live in the Las Vegas area, which is one of the fastest growing metropolitan areas in the nation. Located in underground aquifers, twentv-five percent of the citv's water originates in the soring Mountains. At present, only the Mt. Charleston portion of the ranqe is national forest. It is important that the entire watershed be manaqed by one agency and that agencv be the U.S. Forest Service with its long historv of oualitv watershed management. 
Senator Wallop

September 19,1986

Page 4

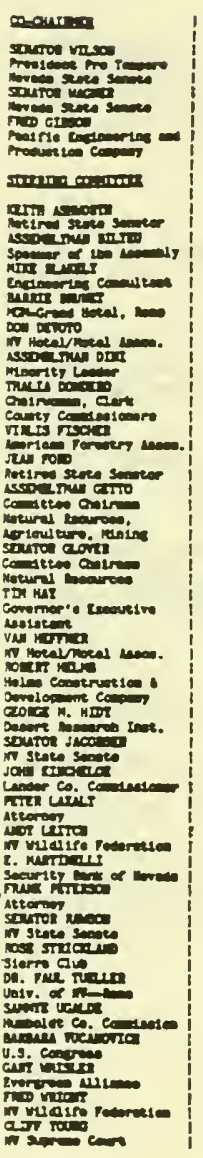

The Spring Mountains are valuable as an outdoor recreation area. It is the onlv area within a reasonable distance of Las Vegas which provides forests, streams, snow, skiing and an escape from summer heat. The U.S. Forest Service is the nation's leading outdoor recreation agency, providing more campgrounds, trails and public areas than anv other government entity in the county. The Forest Service is the logical agencv to develop the sprina Mountains into their full recreational potential.

Recentlv, manv citizens in Las Veqas have said that all of the Spring Mountains, not just the northern portion, should be added to the national forest. The Task Force supports their proposal that Lovell Canvon and Mt. Potosi in the southern spring Mountains be added as well. It is not efficient and goes against the objectives of this bill to continue to have two aqencies managing the same mountain range. We have enclosed a map that shows our recommended boundary for the Sprina Mountains.

\section{AGENCY AGREEMENT}

On January 22, 1986, the three chairmen of nur National Forests Task Force, Sue wagner, Fred Gibsor, and myself, met with all of the Nevada Congressional Deleqation and with the Chief of the Forest Service, together with staff, and the Assistant Director of the BLM, together with staff, as well as a representative of Nevada's aovernor and others. The purpose of the meeting was to reach consensus on that part of the general interchange bill as it would affect Nevada.

That group reached consensus, without obiection, on the present content of S2698, qualified onl" b\% the observation that the Spring Mountains acreage was ront identified to include the Lovell Canvon and the Mt. Prtosi areas at that time.

As it became increasingly apparent that the connal interchange bill had little support and would ... be approved by the Congress during this Session, we 1n $\because . . .3$. and our Conqressional Delegation aqreed that the ccr..... of the general interchange bill, as it would apply to $\because . . . .$, , 
Senator Wallop

September 19,1986

Page 5

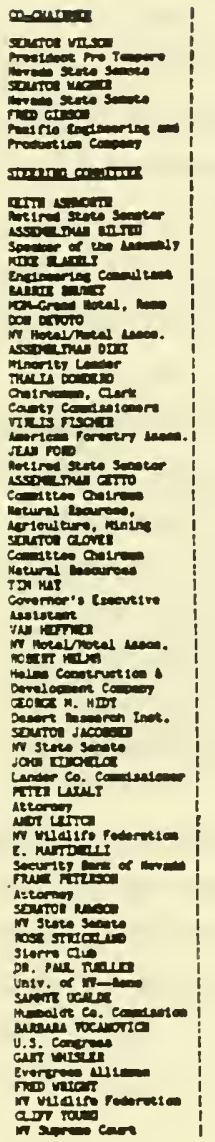
should be introduced separatelv and processed by the Laxalt and Senator Hecht in the United States Senate.

Because of this background and the foregoing reasons, I have come from Nevada to present this testimonv to you today. Thank vou for hearing me.

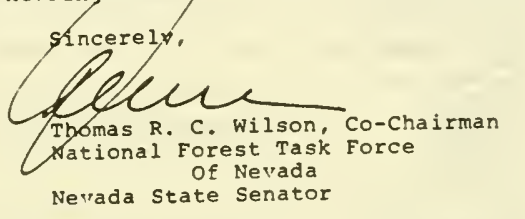


THE MATIONAL FOREST TASK FORCE OF NEVADA
P.O. BOX 2670

Reno, NV 89505

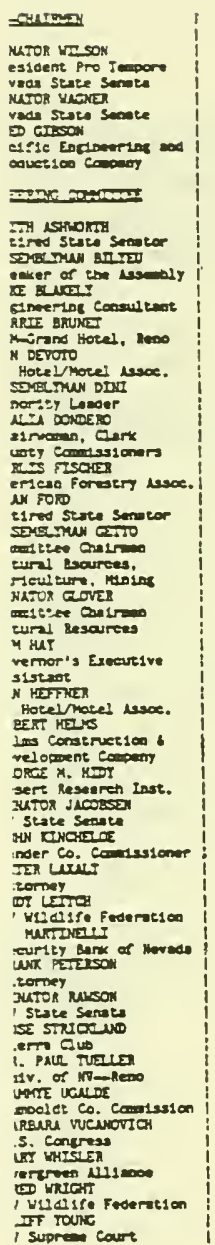

\section{TESTI:ONY OS}

SÜE WAGINE?

NEVADA SFATE SENATOR

at

Fearings of Senate Subcomittee on Public Iands and Eorests

in the COIFIITEE ON ENERGY AND NATURAL RESOURCES

on

S. $5 £$

THE NATEONAL FORESTS AND PUSLIC LANDS ENHANCEMINI ACT OF 1987 June 30,1987

I an Sue : acner, Nevaca State Senator anc a co-chairman cf the Nationa: Zorests Fas:: Force of Nevaca. I an sorry that I cannot appear before "ou personally to celiver tris testimony. However, I wish to assure you that $\mathrm{m} \cdot \mathrm{l}$ enthusiasm for seeing this legislation convertec into law has not lessenec; as I remain convinced that this proposal would not ouly implement the original objectives of the Interchange s.ct for the state of Nevacia, but woulc great?y eniance public lands ranagement and public opportunities for all Nevadans.

Aporoximately two and one-half years ago, it was ciscoverec that the current Acrinistration was implementing a propcsa? to eliminate most of the National Forest system land in the state of Nevada, along with several other National Forests in other 
THE NATIONAL FOREST TASK FORCE OF NEVADA

TESTIMONY OF

SUE WAGNER

NEVADA STATE SENATOR

Page 2

states. In response, concerned citizens organized the National Forests Task Force of Nevada. Chaired by then State Senator Thomas "Spike" wilson, Fred Gibson and myself, a coalition was created to fight the transfer. After the Administration's plans were fully disclosed, hearings were held across the state of Nevada at which over a thousand Nevadans testified that they opposed the wholesale land transfer and declassification of National Forests in their state.

The combined voices of the Task Force and testimony of Nevadans from across the state not only was successful in opposing the flawed declassification proposal, but resulted in a complete turn-around whereby existing Public Domain land with National Forest character would be added to the National Forest System. In response to this overwhelming support, the Task Force co-chairmen arranged a meeting in Washington with the Nevada Congressional Delegation, the Chief of the Forest Service Max Peterson, and representatives of Nevada's Governor Richard Bryan and the Director of the BLM. This group agreed that Interchange objectives could be accomplished by adding Public Domain land to the existing National Forest system. Later, when it became evident that the National Interchange Act was not going to proceed, H.R. 5277 (the National Forests of Nevada Enhancement Act of 1986) was introduced to transfer over 
THE NATIONAL FOREST TASK FORCE OF NEVADA

TESTIMONY OF

SUE WAGNER

NEVADA STATE SENATOR

Page 3

500,000 acres of land administered by the BLM to the U. S.

Forest Service. This act enjoyed the strong support and

endorsement of the National Forest Task Force of Nevada and its citizens. H.R. 5277 passed the House, but failed to come to a vote in the senate when the controversy over water rights arose at the last moment. The 99 th session of Congress adjourned, killing the bill.

I support the National Forests and Public Lands of Nevada Enhancement Act of 1987. Passage of this act will benefit the state of Nevada and the United States for the following reasons:

1. Increasing the acreage of National Forest system land in Nevada will show that Congress and this Administration truly care for the state of Nevada and do not consider it simply a desert wasteland. This will certainly enhance Nevada's image.

2. Because the Forest Service's funding to local agencies is more generous than that of the BLM, revenue to state and county governments will increase.

3. The Eorest Service's larger budgets and professional, non-partisan multiple-use management will improve the condition of the natural resources on these lands.

4. Because these lands are adjacent to existing National Forests and are part of the same watersheds and mountain ranges, putting them under the management of one agency will be more 
THE NATIONAL FOREST TASK FORCE OF NEVADA

TESTIMONY OF

SUE WAGNER

NEVADA STATE SENATOR

Page 4

efficient and cost-effective. Both Nevadans and tourists will experience less confusion and more convenience.

In 1906 , Nevadans partitioned Congress to establish

National Forests to bring regulation and management to the range resource. Congress responded by creating the Toiyabe National Forest in 1907 and the Humboldt National Forest in 1908. Again, Nevadans are coming to Congress asking its members to increase National Forest System acreage.

At the end of your session last year. I was disturbed when I found out the Enhancement Act did not pass because of controversy over water rights.

First of all, the land which we are proposing to add to the National Forest system should not be any different or come under any other rules and regulations than the land already existing in the system. Water is a precious natural resource in Nevada, as it is in other western states. National Forests' use of water is basically non-consumptive and is essential for management of the wildlands. Most of the water on lands involved in this bill in the sierras is federally adjudicated, and there is very little water involved on the lands under consideration in the spring Mountains near Las Vegas. It seems terribly inappropriate to try to resolve a national issue involving water rights with a bill whose primary constituency 
THE NATIONAL FOREST TASK FORCE OF NEVADA

TESTIMONY OF

SUE WAGNER

NEVADA STATE SENATOR

Page 5

is the citizens in the state of Nevada.

Another area of contention is the boundary of those lands in western Nevada. At our January 22, 1986, meeting with the Delegation, Max Peterson and representatives of Governor Bryan and the BLM, we agreed the boundary should be U.S. Highway 395 . There have been adjustments made in that boundary in this bill to accommodate special interests. This issue should be resolved in a way that best meets the needs of the public and the management of the natural resources.

I will close by pointing out that rarely has interest in a bill been so high and endorsed by so many in the state of Nevada as this bill. Nevadans were instrumental in seeing the National Forests created in their state, now Nevadans would like to see additional lands added to the National Forests within their state. A prompt passage of this bill will show that you care for Nevada and those lands and natural resources within its boundary.

Please make this testimony part of the public record of these hearings. Thank you. 
RICHARD H. BKIAN

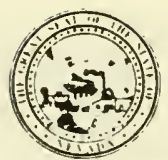

THE STATE OF NEVADA

EXECUTIVE CHAMBER

Carson Cily. Nevada 89710

TLIPHONI

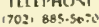

June 3,1987

The Honorable J. Bennett Johnston

Chairman

Committee on Energy and Natural Resources

United States Senate

Washington, D.C. 20510

Dear Chairman Johnston:

I am writing to you to voice my strong support for S.854, the proposed Nevada-Florida land exchange between Aerojet General Corporation and the Department of the Interior which is currently pending in your committee.

I know that the press of Congressional business is intense and that there are many worthy pieces of legislation which you and your cormittee must review this year. However, the Aerojet legislation is terribly important to me and to the entire state of Nevada as its passage will provide our state with hundreds of new jobs and the potential for greater economic diversification. Therefore, I respectfully urge you to process this legislation as quickly as possible.

Aerojet has gone to great lengths to satisfy the legitimate environmental concerns which have been expressed over this exchange. Hearings will not only allow these facts to come to light but will give the opponents as well as the the proponents of the legislation a chance to air their views.

Thank you for your consideration of this request and I will look forward to hearing from yop.

RHB/SC
CC: Nevada Congressional Delegation

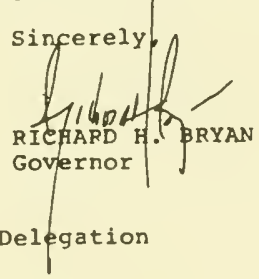


Assembly Jount Resolution No, 21--Assemblymen Schofield, Dini, Jeffrey. Price, Spriggs and Callister FILE NUMBER. 98

ASSEMBI.Y JOINT RESOI.UTION.-Urzing the President to supmen and Congress to convumialc the crechange of certuin public land in Nevade for privalc land owned by Aerojet-General Corporatum

WHEREAS. The State of Nevada has worked very hard to strengthen and diversify its economy; and

WHEREAS, The Federal Government currently controls 87 percent of the land in Nevada: and

WHEREAS. Aerojet-General Corporation has proposed to exchange certain land owned by it in Florida for federally administered land in southern and western Nevada for industrial development and testing: and

WHEREAS. The Florida land will be used to achieve the protection of valuable natural vegetation in the Everglades; and

WHEREAS. Industrial development is needed in strengthen and diversify Nevada's economy and the proposed development by Aerojet will help provide Lincoln County with a more stable economic base which is vitally needed: and

WHEREAS. Aerojet has caused environmental evaluations of its proposed sites in southern and western Nevada and agrees to use the sites in a manner which will minimize any adverse effects on the environment and agrees 10 mitigate those adverse effects; now, therefore, be it

RESOLVED BY THE ASSEMBLY AND SENATE OF THE STATE OF NEVADA. JOINTLY. That the Nevada Legislature urges the President to support and Congress to enact legislation consummating the exchange of certain private land owned by Aerojet-General Corporation in Florida for certain public land located in southern and western Nevada if a right-of-way corridor not more than 1-mile wide is reserved therefrom to the United States for the construction, operation and maintenance of electric Iransmission lines; and be it further

RESOLVED. That copies of this resolution be prepared and transmitted forthwith by the Chief Clerk of the Assembly to the President of the United States, the Vice President of the United States as presiding officer of the Senate, the Speaker of the House of Representatives and to each member of the Nevada Congressional Delegation; and be it further

RESOLVED. That this resolution becomes effective upon passage and approval. 
STATEMENT OF

THE HONORABLE RICHARD H. BRYAN

GOVERNOR OF NEVADA

submitted to the

SUBCOMMITTEE ON PUBLIC LANDS, NATIONAL PARKS AND FORESTS

COMMITTEE ON ENERGY AND NATURAL RESOURCES

UNITED STATES SENATE

on

S. 854 - NEVADA - FLORIDA LAND EXCHANGE AUTHORIZATION ACT

June 30,1987 


\section{TESTIMONY BBPORB THE SBNATB COMMTTTEE OA BNERGY AND NATURAL RESOURCES \\ 8UBCOMMTTRE ON PUBLC LANDS, NATTONAL PARKS AND FORBSTS June 30, 1987}

8,854: Nevada-Florida Land Exchange Authorization Act of 1987

Mr. Chairman members of the committee, the state of Neveda appreciates the opportunity to enter testimony on S. 854, the Nevada-Plorlda Land Exchange Authorization Act of 1987.

Aerojet-General Corporation has augzested the acquisition of land needed for a new Industrial facllity in Nevada through the exchange of Aerojot lands In Florida for the desired site in Nevada. The Nevade al to contalns approximately 43,000 acres of public land and is located in Coyote Spring Valley. The land is presently managed by the Bureau of Land Management.

Aerojet also wishes to enlarge It existing testing site in the Garfield Flat area of Mineral County through the acquidtion of approxdmately 8,800 acres in that area

As you are no coubt aware, Keveda's mural areas heve sparse populations and IIttle private lands. Many rural commundtes are struggling economically. Posdbinities for economlo development are oharply reduced due to the lack of private land. Por example, moat of the Coyote sping site lies in Lincoln County. Lincoln County has an exea of 8.8 million ecres, but leas than two percent of this land is in private ownership. Uncoln County's populetion b about 4,000, for a populetton density of less than one-half a person par square mlle. Mineral County has total area of 2.5 million acres, of whlch only two and a half pereent is in private ownershtp, and a population of about 6,000 , for a population density of about one and a half peraon per square mile. 
Page 2

In many of our rural areas, populations are acturlly declining as young people leave, unable to find opportunities for economic advancement.

Faced with these reallties, my administration has devalopad a strong program of economle development and diveraifleation. We are particularly committed to attracting new firms and developments to our rural arees.

For more then a year, state agendes have been evaluating this proposal by A rejot-General. It would bring jobs to Neveda, and would put additional lands on our tax rolls. These benefl ts could involve some costs. Aerolet has been cooperating with state agencles in estimating these costs and devaloping appropriate mitigations. The State Department of WIdlfe has analyzed the Impacts on wildlife populations and requested a varlaty of $\mathrm{mlt}$ gatory measures, Including the setting aside of a conservation reserve and the provision of new wildlie watering lacilities. The Department of Conservation and Natural Resources will require permlts lor weter use and for disposal of waste materials, and any permits laued will be subject to stringent monitoring and enforcament reguirements. State standard are hgh, and the state wlll not permit damage to state resouroes.

As these lands move into peivate ownership and Acrojot proceeds with Its plans, the state will continue to work closely with the company to ensure maximum banefits to the state and its poople. 
TESTIMONY OF THE HONORABLE JAMES H. BILBRAY,

REPRESENTATIVE OP THE STATE OF NEVADA IN CONIRESS,

BEFORE THE SENATE COMHITTEE ON ENERGY AND NATURAL RESOURCES

SUBCONMITTEE ON PUBLIC LANDS, NATIONAL PARKS AND FORESTS

CONCERNING S. 854: THE NEVADA-FLORIDA LAND EXCHANGE AUTHORIZATION ACT OF 1987

June 30,1987

Mr. Chairman and members of the committee, thank you for the opportunity to enter testimony on S. 854, the Nevada-Florida Land Exchange Authorization Act of 1987.

This legislation would permit Aerojet General Corporation to acquire 54,000 acres of Bureau of Land Management land in Clark, Lincoln and Mineral Counties in Nevada by transferring to the Department of Interior approximately 4,800 acres of Aerojet-owned Iand contiguous to the Everglades. The Department of the Interior would in turn sell the Florida land to the State of Florida and purchase environmentally-sensitive lands in Florida with the funds. 
Aerojet General has indicated the land located in Coyote springs valiey is needed for the construction of a new industrial faclitity which would fabricate and test solid rocket wotors. Approximately 43,000 acres are needed at the Coyote springs Valley site.

As you know Mr. Chalrman, rural Nevada is sparsely populated with few lands held in private ownership. Many of these rural communities are facing difficult economic times, and because such a large percentage of the land in the county is not privately owned, development opportunities are $11 \mathrm{mited}$.

Nevada, recognizing the dire consequences of this pattern should economic hard times continue, has vigorously pursued a program of economic development and diversification. This program can only succeed if development of private lands is possibie. I support programs which have the effect of returning as many federally-owned lands to private Nevadans as possible.

Certalnly, environmental concerns must be addressed. The presence of the proposed Coyote springs Valley facility ralses questions regarding the company's impact on water, nat 1 ve plants and animals, and environmentally-sensltive 
species such as the desert tortoise. In addition, questions have also been aimed concerning a proposed power utility corridor through the property for future power projects.

Agencies of the State of Nevada have joined with Aerojet and federal agencies to develop appropriate mitigations which are attached to the legislation. The Nevada Department of Wildilfe and I have insisted upon various mitigation measures which include the setting aside of an 18,000 acre nature conservatory. In addition, provisions have been included for the installation of widlife watering devices.

The State Department of Conservation and Natural Resources as well as the State Water Engineer will require permits for any water use. In addition, these agencies will closely monitor Aerojet's activities and have indicated to me that any permit for water use or waste disposal will be conditional upon the company's compliance to the state's strict requirements. From my tenure in the Nevada senate Comittee on Natural Resources, I can attest first-hand that Nevada's standards in these areas are among the most stringent in the nation. I wight add that over one-fifth of the property has been dedicated to providing a power corridor for future power needs. 
Mr. Chalrman, the proposed legislation if enceted would not only bring jobs to Nevada but would expand her property tax rolls. I joln the Governor of Nevada, the other members of the congressional delegation, the Nevada Association of Counties, the Board of County Commissioners of Clark and Lincoln Counties, the City of North Las Vegas, the Ploche Town Board, the Alamo Town Board, the Panaca Town Board, and the Caliente City Council in support of this measure. This bil1 represents a sound balance between economic diversification and environmental sensitivity.

Mr. Chalrman, I urge favorable consideration of this measure and further urge markup by the full commlttee.

Thank you again for this opportunity. 
STATEMENT OF CONGRESSMAN DANTE B. FASCELL BEFORE THE SUBCOMMITTEE ON PUBLIC LANDS, SATIONAL PARKS AND FORESTS OF THE SENATE COMMITTEE ON ENERGY AND IATLRAL RESOLKCES IN SUPPORT OF S. 854 , THE NEVADA-FLORIDA LAND EXCHANGE ALTHORIZATION ACT June 30,1987

Yr. Chairuan and members of the subcomittee, I appreciate very wuch your providing this opportunity for those of us who are interested in this legislation to be heard. The proposal to exchange certain lands owned by the terojet Corpuration in South Florida for federally-owned lands in Sevada has been on the table for over a year now. This hearing will enable al those concerned with its inpact to express their support or concern, along with their expertise and will enable you to have the benefit of all points of view in order to help you nake a determination as you act on the legislation.

obviously, 1 an most familiar with the florida aspects of the bill and will leave to our distinguished colleagues from Nevada the task of discussing their portion oi it.

Siaply put, trom the Florida point of view, this legislation ts good for florida and is good for the national interest as well. The terojec-owned lands in Florida would be given to the federal government in exchange for land of approximate equal value in Nevada. These values, as I understand it, have been determined by two separate, indepeodeot appraisals. In turn, the South Florida Water Management District would purchase the Florida lands trom the federal government and the proceeds from the purchase 


\section{2}

would be used by the U.S. Fish and Wildlife Service to acquire lands within National Wildife Refuges in Florida, thereby further protecting Endangered Species with no outlay of appropriated funds by the federal government.

The lands in question are immediately east of Everglades National Park and wil be managed by the Water Management District in a manner to benefit the Park through its control of water deliveries. The management of these Iands has long been a controversial issue in south Florida and its addition to the public domain will help ensure that it will be protected and used in an environmentally-sound manner.

In addition to these evironmental benefits, Aerojet, a mafor contractor for projects in both the national defense and space efforts, would acquice land it badiy needs to expand its facilities and Nevada would gain the jobs and other economic benefits that would result therefrom.

Mr. Chairman, there is another issue Involving Aerojet-owned lands just north of those included in this proposal which, though related to this is not and should not be considered as part of this legislation. I refer to an area known as the Frog Pond which is presently being leased on a year-to-year basis by tomato farmers who formerly were able to farm land in the Hole-in-the-Doughnut area of the Everglades National Park unil the federal government terminated that useage. The Aerojet landa now belng farmed are the only suitable remaining land available for farming in south Dade County. They provide forty per cent of the nation'a winter tomato supply. There has been wuch concern expressed about the impact of agricultural activities on the ecology of the park as a result of the water delivery schedules in this area. While the Park Service has repeatedly 


\section{3}

Indicated to me that it does not want to eliminate farming in the frog pond, It does want to be able to control the water schedules in a maner which could result in flooding for part of the growing season, thus wiplng out a portion of the season's crop.

I do not want to leave any lmpresilon that my aponsorship of this legislation and wy strong support for it 18 in any way intended to affect the farming activities in the Frog Pond. It is my understanding that discussions are under way between Aerojet, the farmers, Park officials and the Water Magagement Diatrict to work out an agreement which would enable the Park to have the water schedule it needs without depriving the farmers of the extra crop they need to remain economically viable. This agreement will require some compromise on the parts of all concerned but, 1 achieved, could put to rest once and for a 11 a controversy that has raged for more than a decade. It is my ancere hope that all the parties will go the extra wile necessary in order to make this work.

Nevertheless, this issue should not impact on or affect in any way the legislation under discussion today. The transfer of the Aerojet lands in this b111 and their subsequent sale to the South Florida Water Management District are environmentally sound and will not cost the federal government anything. As a bonus, the proceeds from the sale will provide further environmental protection in the form of land purchases within the National Wildife Refuge system in Florida, Including the Key Deer National Wildife Refuge on Big Pine Key.

Thus, I belleve this is a good deal all around and should be approved. 
$\underline{4}$

I would like to add that Aerojet has already donated thousands of acres of environmentally sensttive land to the state of Florida in this same general vicinity. These lands are now being managed by the south Florida Water Management District much as those included in this legislation would be.

Again, I thank you for taking the time to hold this hearing and for giving me and those from Florida who will testify later an opportunity to present the Florida point of view on this exchange. 
TESTIMONY OF FORMER U.S. SENATOR PAUL LAXALT

AT HEARING OF SUBCOMMITTEE ON PUBLIC LANDS AND FORESTS

IN SENATE COMMITTEE ON ENERGY AND NATURAL RESOURCES

ON S. 59 (THE NATIONAL FORESTS AND PUBLIC LANDS OF NEVADA

ENHANCEMENT ACT OF 1987)

WASHINGTON, D.C.

JUNE 30,1987

I am Paul Laxalt, attorney-at-law, and former United States Senator from Nevada. While I am not able to attend the Subcommittee hearing in washington, D.C., I would ask that my testimony be made part of the public record of said hearing.

I support the National Forest and Public Lands of Nevada Enhancement Act of 1987.

The Forest Service has a proud tradition in Nevada. At the turn of the century, most of Nevada's rangelands were damaged severely. Two million sheep and cattle grazed the public domain without controls. Deterioration became so serious that in 1906, Nevada's ranchers petitioned Congress to establish national forests to bring regulation and management to the range. Congress responded by creating the Toiyabe National Forest in 1907 and the Humboldt National Forest in 1908 .

This point bears closer scrutiny. Nevadans wanted the National Forests to be created in Nevada. Congress was responsive in establishing our two national forests. In 1985 , there was an effort by some to decrease the national forest 
lands in Nevada by trading them away to the Bureau of Land Management (BLM) through an Interchange proposal. Once again Nevadans voiced their support of the U.S. Forest Service. At hearings held in Reno, Las Vegas, and Elko, a great number of Nevadans testified of their dismay at the prospect of losing the national forests in Nevada.

At that time, the co-chairmen of the National Forest Task Force of Nevada, the entire Nevada Congressional delegation, including myself, the Chief of the U.S. Forest Service, and representatives of the Governor of Nevada and the Director of the Bureau of Land Management met in Washington, D.C. We all agreed that several of the goals of Interchange, including ease of administration and administrative efficiency, could best be accomplished by transferring some lands administered by the BLM to the jurisdiction of the Forest service.

From this agreement, legislation was introduced and passed the House during the $99 t h$ Session of Congress, but failed to come to a vote in the Senate before the session adjourned. Dedicated to following the wishes of their constituents in Nevada, Congresswoman Barbara Vucanovich and Senators Chic Hecht and Harry Reid, re-introduced comparable legislation in the forms of H.R., 267 and S. 59 during the opening days of the current session of Congress.

However, with due respect for its sponsors, I am of the opinion that the legislation will have greatly improved chances of passage if it is amended in two respects. 
IESTIMONY OF SENATOR PAUL LAXALT, JUNE 30, 1987

First, to refresh the recollection of all concerned, the delegation achieved agreement during the last session, along with all those involved, as to boundaries. I think it is important that the boundaries in the current bills be restored as nearly as possible to those established in the 1986 bills.

The Peavine Mountain area is characteristic of national forest lands and should be included in the enhancement area. Peavine is important to the citizens of Washoe County for the recreation it offers, as a scenic backdrop to the cities of Reno and sparks, as watershed for the City of Reno, and as critical wildlife habitat. It is my understanding that washoe County has adopted a resolution for Peavine inclusion and that the Cities of Reno and Sparks will do the same.

Such inclusion will also ease administrative burdens in the area. As now proposed, s. 59 does little to improve the administrative capabilities of either agency in the Peavine area. In fact, should the bill pass with the current boundaries, only one half of one section near Peavine Peak will transfer from the BLM to the Forest Service. We must remember that one of the goals of both the Interchange legislation and subsequent Enhancement Act bills was to help alleviate administrative inefficiencies.

Secondly, the water rights language currently contained in the bill is unsatisfactory, in my opinion. Subsection (b), Section 8 , of S. 59 as written is identical to subsection (b) 
of Section 5 of both S. 2698 and H.R. 5277 of the 2 nd Session of the 99 th Congress. It was disapproved by the House and eliminated from H.R. 5277. With that experience in mind, its inclusion in the same form in S. 59 and H.R. 267 could prevent passage of the Act by Congress.

This bill, which deals only with Nevada, need not and should not be the forum for solving controversial and complex national issues as to water rights, especially when there is little water on the lands affected by this bill over which to argue. All the water on the lands in western Nevada is now federally adjudicated. There is very little surface water in the Spring Mountain Range addition. It would be a shame if this bill, which has received widespread public support, were to fail again over an issue which is largely inapplicable to the pending legislation.

To enhance the opportunity for passage of the legislation, I would recommend that it contain the attached language, which adequately protects all interests and has been approved by the Nevada State Engineer, the State Director of the Department of Commerce and the National Forest Task Force of Nevada, and would, I believe, be acceptable to the Forest Service. Moreover, it respects the concerns, primarily of western Senators and Representatives, in the premises.

The lands subject to transfer to the jurisdiction of the Forest Service deserve the improved management the Forest Service can offer. As a contrast, the Forest Service spends $\$ 2.00$ per acre, the BLM spends $\$ .43$. 
TESTIMONY OF SENATOR PAUL LAXALT, JUnE 30,1987

The coffers of Washoe, Douglas, Carson City, and Clark counties will also benefit by additional Forest Service lands. The size of each county's share of receipts or revenues generated on forest lands is determined by the county's acreage of natioanl forest. The law requires that the county spend these dollars on roads and schools. Especially in washoe and Clark counties which are growing by leaps and bounds, every additional source of income will be a welcomed benefit.

While the Forest Service allocates a flat 25 percent of its revenue generated from these lands to the counties, the BLM uses different percentages for different types of $l$ and and products. For instance, the revenue from grazing fees on 93 percent of the BLM's land in Nevada is returned to the counties at the rate of only 12.5 percent.

Nevadans were instrumental in seeing the national forests created in Nevada. Now, Nevadans would like to see lands added to the national forest system in our state. By passing S. 59, the Senate will prove that it is receptive to the desires of Nevadans.

Thank you for your consideration.

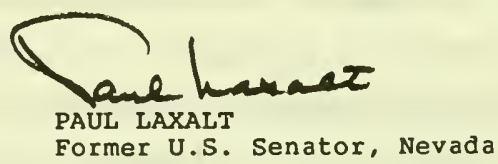




\section{SUGGESTED CHANGES TO: \\ "Bational Forests and Public Lands of Vevada Enbancement Act of 1987"}

SEC. 8. WATER RIGHTS.

(a) PRIOR EXISTING WATER RIGHTS.--Nothing in this Act shall be construed to expand or diminish ang water right of the United States under State or Federal law which the United States bad. or may be determined to have had by purchase, reservation, or otherwise, before the date of enactment of this Act.

[(b) NO FEDERAL RESERVED MATER RIGBTS Bi REASON OF TRANSFER.-The desigation and withdrawal of newly established national porest lands by this Act shall not create any reserved water. rights in the United States by reason of this Act with respect to those lands.]

(b) Nothing in this dit shall be construed to establish a new express or implied reservation to the linited States of any water or water right with respect to the land described in the fct: Provided, that the lnited States shall be entitled to only that express or implied reserved water right necessary and limited to primary purposes of the land transferred to Forest Service jurisdiction and further limited to those minimum quantivies of water required to carry out the primary purpose of the reservation. Any such right carries a date of priority of the date of enactaent of this legislation. Further provided that this transfer shall not result in any adverse affect or impact on existing water rights.

(c) RIGHT TO ACQUIRE AND DISPOSE OF HATER RIGHTS.-- Nothinz In this Act shall affect the right of the lnited states or of any person to acquire or dispose of water or water rights under applicable law. 
Senator Hecht. Now we have our witness list, and we will start with my colleague, the Honorable Harry Reid.

\section{STATEMENT OF HON. HARRY REID, A U.S. SENATOR FROM THE STATE OF NEVADA}

Senator REID. Thank you very much, Senator Hecht.

Through you, I certainly would like you to express to Senator Bumpers my appreciation for holding this hearing, which has been wanted by many people for a long time.

I appreciate personally the opportunity to testify about S. 854, the Nevada-Florida Land Exchange Authorization Act, and S. 59, the National Forests and Public Lands of Nevada Enhancement Act of 1987.

I have joined with you in the introduction of both these bills.

The Nevada-Florida Land Exchange Authorization Act will allow Aerojet General to acquire 51,710 acres of Bureau of Land Management land in Nevada in exchange for approximately 4,660 acres of Aerojet-owned land in Dade County, Florida, near the Everglades.

The Interior Department would then sell the Florida land to the South Florida Management District to raise funds for acquiring additional wildlife refuge lands in the State of Florida.

In Nevada, the legislation includes approximately 8,900 acres of land in Mineral County, 25 miles southeast of Hawthorne, adjacent to the Garfield Flat test site, already owned by Aerojet. The larger 42,800 acre portion is located in Clark and Lincoln Counties, in the Coyote Springs Valley, 45 miles northeast of Las Vegas and about 100 miles southwest of Caliente.

Aerojet wants to acquire the Nevada BLM land to construct a rocket manufacturing, assembly and test facility.

Since 1955, Aerojet has operated a 13,500 acre manufacturing facility for solid rocket motors 20 miles east of Sacramento, which employs 4,200 people. The Nevada land will supplement the company's rocket testing operations. It is anticipated that the facility will initially employ 200 people with the potential of providing jobs for many more people in the future.

Mr. Chairman, you being from Nevada are aware that the land exchange proposal enjoys widespread and strong support, including the endorsement of the governor, the assembly, the residents of Lincoln County, as well as the Southern Nevada Development Authority.

However, there have been some concerns raised about the impact of the company's presence on water, existing minerals, and native plants and animals, as well as the appraised value of the Nevada land.

These hearings and the ones which I will conduct in Nevada on August 13, will help Congress evaluate the concerns that have been raised by these various groups and people.

During the past few years, I have worked with Aerojet in the company's efforts to facilitate the exchange. In my mind, Aerojet has worked to resolve many of the concerns that have been raised. For example, Aerojet is setting aside about 18,000 acres of the Coyote Springs Valley land for a period of 20 years as a conservation area. 
Various conservation groups have expressed reservations about the proposed conversation area, and, again, the hearings will allow us to fully consider these views.

Let me now turn to S. 59, the National F'orests and Public Lands of Nevada Enhancement Act of 1987.

This legislation will transfer more than 500,000 acres of Federal lands in Nevada, currently administered by the Bureau of Land Management, to the United States Forest Service.

A brief outline of the development of this proposal is warranted.

In June of 1985 , the U.S. Forest Service and the BLM announced a proposal to Interchange management of about 30 million to 35 million acres of land and underlying minerals. The purpose of the proposed Interchange was to improve the management of public lands and national forests, enhance public service, and reduce agency costs.

The proposed "land swap" caused an uproar in Nevada.

Under the original plan, Forest Service lands in Nevada would shrink to less than 1 million acres, while the BLM would manage 4.5 million acres. The Departments of Interior and Agriculture also held public hearings in Nevada to gauge the public sentiments about the land swap. The public hearings brought out near unanimous opposition to reducing Forest Service lands in the State.

Too many serious questions remained, ranging from concerns about agency funding, quality of management, the status of revenues to State and county governments, and possible environmental degradation.

Following public input and further deliberation, the U.S. Forest Service and BLM developed a new Interchange proposal, affecting 12 western States and two eastern cities, allowing Nevada to retain all of its existing national forests and converting BLM lands to the Forest Service.

The administration sent another omnibus Interchange proposal to Capitol Hill this Congress. But there is no serious movement on the legislation and support is negligible.

At the urging of the National Forest Task Force of Nevada, the Nevada delegation has introduced this legislation to enlarge and enhance our valuable Forest Service lands. The Enhancement Act has broad support throughout the State including Governor Bryan, the Board of Commissioners of Clark County in the southern end of the State, and the Washoe County Commissioners in the northern end of the State.

I would like to mention at this point, however, two reservations I have about the bill that have also been expressed to me by constituents.

One is the inclusion of 17,000 acres around Peavine Mountain. This area is an especially important scenic peak that can be seen from Reno. It is a valuable watershed that includes White Fir, Jeffrey Pine and Ponderosa Pine. It is also the winter range for 2,000 deer.

This area was included in the Enhancement Act introduced last Congress, and I understand was excluded this year because of complaints by a mining interest in the area.

I do not agree with the exclusion of the area, and the fact that it is an issue. The support this legislation already enjoys from the 
State and local governments would be significant enhanced if the Peavine addition is made.

Second, I believe the current water language is unnecessary and restrictive. I would, however, be glad to discuss compromise language on this issue.

Except for these two points, I fully support the Enhancement Act and urge quick and favorable action.

Thank you for allowing me this time to testify before the Committee on these two bills that are important to the State of Nevada.

Senator Hecht. Thank you very much.

When is your hearing in Nevada?

Senator REID. August 13.

Senator Hecht. Then we will hold up any movement of this legislation until such time as you have had a hearing on it.

Senator REID. I appreciate that. We will be happy, for any witnesses that weren't able to come here, if you would inform me or have someone do so, we will work those in. We would be happy to work with you any way we can on that.

Senator Hecht. Okay.

Thank you very much. I know you have a busy schedule.

Now we have our senior Congressman from Nevada, who is, besides my wife, my favorite person, Barbara Vucanovich.

\section{STATEMENT OF HON. BARBARA F. VUCANOVICH, A U.S. REPRESENTATIVE FROM THE STATE OF NEVADA}

Mrs. Vucanovich. Thank you, Mr. Chairman.

I appreciate Senator Bumpers holding this hearing, and I certainly am glad that you are here today to take his place temporarily. And I would like to thank you for the opportunity to testify before you today on these two bills that are so important to our State.

I think we also would like to welcome the many Nevadans who have travelled to Washington to testify at this hearing.

Both these issues are very important to people in Nevada.

Mr. Chairman, I'd like to begin with S. 59.

As you know, and as has been stated, this bill will exchange lands between the National Forest Service and the Bureau of Land Management in Nevada. It was introduced in the 99th Congress as a result of the BLM's 1985 Omnibus Interchange Proposal, that would virtually have eliminated the national forests in Nevada.

The citizens of Nevada felt an urgent need to protect and preserve their national forests and created a bipartisan task force, of which I am a member, to develop an alternative to the proposal.

Legislation was introduced by the entire delegation in the 99th Congress that would add to, rather than eliminate, forest lands in the State.

This legislation passed the House, but failed to come to a vote in the Senate before the session adjourned.

The major stumbling block during the last Congress dealt with water language. The House version was passed without reference to water; but, unfortunately, that was not acceptable to the Senate. 
During this Congress, however, we have time on our side, and I believe we can work together to develop water language that adequately protects all interests.

Mr. Chairman, this is a good bill for Nevada. It is a demonstration of the power of the people and has the full support of the Nevada delegation as well as that of the governor.

I hope this Committee will act favorably on this measure.

I would now like to take just a minute and express my support for S. 854, the Nevada-Florida Land Exchange Act. This bill will authorize private wetlands in Florida, owned by Aerojet General Corporation, to be exchanged for public lands of equal value in Nevada, which are managed by the Bureau of Land Management. The companion legislation in the House is co-sponsored by Congressman Bilbray of Nevada, as well as Congressman Fascell of Florida, whose district is impacted by this exchange.

This legislation is beneficial to both Nevada and florida. It will allow Aerojet to acquire about 42,800 acres of land in Lincoln and Clark Counties to construct a new facility to test rocket motors, which will generate hundreds of jobs in an economically-depressed area. There will be some people from Nevada who will be testifying about the economic situation in Lincoln County, as well as some of the other counties.

It also provides for Aerojet to acquire approximately 8,900 acres in Mineral County to expand current operations.

This exchange will return public rangeland to the tax rolls of the State and give a much needed economic boost to Nevada.

This bill gives the South Florida Water Management District the opportunity to acquire approximately 4,650 acres of wetlands which it has been hoping for for some time, which are similar and contiguous to the Everglades National Park, and will be managed for conservation purposes.

The delegation has worked closely with Aerojet to insure that adequate controls are implemented to protect the environment and the desert habitat in the area.

An example of this is the approximately 17,000 acres that Aerojet has set aside as a deed restriction and dedicated as a tortoise preserve for the protection of the desert tortoise. Negotiations have also taken place with the State Department of Conservation and Natural Resources for any water permits and waste disposal permits that might be issued.

The State standards are high, and damage to State resources will not be permitted.

This is also a good bill for Nevada and has the support of the entire delegation, as well as the governor. The bottom line is jobs and economic diversification, two things that are extremely important to our State.

I support this bill and urge its rapid passage.

I thank you again for allowing me to testify, and I would be happy to answer any questions that you might have.

Senator HECHT. Thank you very much. I appreciate your testimony and I appreciate your interest.

I am happy our delegation is all together.

Mrs. Vucanovich. We are.

Senator Hecht. Thank you again. 
Mrs. Vucanovich. Thank you, Senator Hecht.

Senator Hechт. I see Robert Burford out here, the Director of the Bureau of Land Management. I think he has "squatter's rights" on this bill. I was here this morning for a hearing, and he was here then. He has not gone yet.

In the essence of time, I am going to ask Mr. Horn, Mr. Burford, Mr. Leonard and Mr. Bok to all four come up. Using the prerogative of the Chairman, we have a lot of people from Nevada who have flown out at considerable expense to themselves, with time and effort away from their jobs, their businesses and their homes, so I am going to ask all of you to limit your testimony so that they can have a few extra minutes. Is that fair enough?

If you want anything put into the record, please do so. But, please, summarize your testimony.

Bob, you may want to go on first, since you have been here all morning. You may then want to leave. That would be fine with me. You can only stay in this room about 12 hours a day, and then we kick you out when we clean up. [General laughter.]

\section{STATEMENT OF ROBERT F. BURFORD, DIRECTOR, BUREAU OF LAND MANAGEMENT, DEPARTMENT OF THE INTERIOR}

Mr. Burford. My 12 hours are already up.

Senator Hecht. Well, then, talk fast. [General laughter.]

Mr. BurFord. I am not noted for that.

Senator Неснт. Well, then, you will be shut off, and I am noted for that. [General laughter.]

Mr. BURFORD. In reference to S. 59, I would like to enter my testimony into the record and will very briefly summarize the Department of the Interior's position.

We could support enactment of S. 59 if it were amended to include more States. We think that because it takes in only the State of Nevada, there are not enough savings in dollars or in personnel to go ahead with this.

We would like to see the Committee work with some of the surrounding States to get at least one group of States together, which would allow a part of the Interchange to go ahead.

What we see and what the Forest Service may state on their own is that this change in one State only may leave one part of the forest operating under different rules than other parts of the forest.

We are also concerned that some of the areas of BLM land that are being transferred to the forest have some applications on them for Recreation and Public Purposes Act (R\&PP) sites for camps, schools, et cetera. The Forest Service does not have the R\&PP authority and this bill does not give it to them. So if you do go ahead with the bill, I would suggest you give the Forest Service R\&PP, that you add R\&PP legislation to it, because some of your communities out there do need some of that land and need to be able to acquire some of it.

As far as S. 854, the other bill that is up for consideration, we are in favor of that bill. I think that Mr. Horn is going to present the Administration position's on it. But, speaking for the Bureau of 
Land Management, we think that it is a good exchange and that it should go ahead.

I am the one who is putting up the collateral for the Aerojet exchange. But not being too turf conscious, I think it is an opportunity both for Nevada and for Florida and for the Fish and Wildlife Service.

Thank you, Mr. Chairman.

[The prepared statement of Mr. Burford follows:] 
STATEMENT OF ROBERT F. BURFORD, DIRECTOR, BUREAU OF LAND MANAGEMENT, DEPARTMENT OF THE INTERIOR, BEFORE THE SUBCOMMITTEE ON PUBLIC LANDS, NATIONAL PARKS AND FORESTS, COMMITTEE ON ENERGY AND NATURAL RESOURCES, UNITED STATES SENATE, ON S. 59, ENTITLED THE "NATIONAL FORESTS AND PUBLIC LANDS OF NEVADA ENHANCEMENT ACT OF $1987^{\circ}$.

I sppreciate the opportunity to appear before the Subcommittee today to discuss the Department of the Interior's position on S. 59.

We could support enactment of S. 59 if it were amended to laclude more States. We have substantial concerns with S. 59 as currently drafted. We strongly suggest that the bill include a larger geographic region so that the purposes of the bill - economical and efficlent management snd improved service to the public -- are accomplished. We also suggest that the bill Include certain provisions thst are Identifled in the Administration's Nationwide Interchange B11l for the proper transition and administration of specific lands designations. We belleve the best opportunity to achleve the goals of the 1nterchange program for overall dollar savings and administrative efficlency is through enactment of a nationwide proposal. Individual State legislation would fall far short of the savings and efficlencles generated by a single nationwide bill.

The largest single factor in calculating the savings was the reduction of overhead and administrative personnel that would be made possible by consolidating the Buresu of Land Management and Forest Service offices and reducing the total number of offices. Our research Indicates that no significsnt savings would be realized with enactment of $S$. 59 in the short or long terms. In fact, the costs of distributing records, case files, establishing the new boundaries, and the confusion inherent in these actions, would likely result in aignificant added costs, with little or no savings or improvement in public service. 
S. 59 would be cited as the "Natlonal Forests and Public Lands of Nevada Enhancement Act of 1987."

Section 2 of S. 59 contains congressional findings and purposes of the bill. The purposes would be to transfer to the Forest Service certain public lands in Nevada currently administered by the Bureau of Land Management and to transfer to the Bureau of Land Management certain national forest lands in Nevada currently administered by the Forest Service. The lands identifled for transfer are contiguous to other lands administered by the proposed agency.

Section 3 would define the terms "public lands" and "National Forest 1ands" or "National Forest System lands".

Section 4 of would provide for the transfer of about 511,000 acres of public lands Identified on a map to the Tolyabe and Inyo National Forests. Section .4 would also provide for the transfer of approximately 23,000 acres of national forest land identifled on a map to the Secretary of the Interior.

Section $4(e)$ would provide that lands transferred to the Secretary of Agriculture would be subject to the planning requirements of section 6 of the Forest and Rangeland Renewable Resources Planning Act of 1974 and that lands transferred to the Secretary of the Interior would be subject to the planning requirements of the Federal Land Policy and Management Act of 1976. Amendment or revision of existing plans would not be required as a result of this bill.

Section 5 of S. 59 would provide for management by the Secretary of Agriculture, in accordance with section $603(\mathrm{c})$ of the Federal Land Pollcy snd 
Mansgement Act, of the BLM Mount Stirling and LaMadre Mountains Wilderness Study Areas that would be made part of the Natlonal Forest System by the bill unt1l Congress designates the areas as wilderness or releases them from further wilderness consideration.

Section 5(c) would provide that any roadless area, or portion thereof on nstional forest lands recommended by the Secretary of Agriculture for wilderness which would be transferred to the jurisdiction of the Secretary of the Interior as a result of this bill, would be managed by the Secretary of the Interior in sccordance with the provisions of $603(\mathrm{c})$ of the Federal Land Policy and Management Act.

Section 6 would provide that nothing in the bill should be construed to change the laws governing the management of mineral resources.

Section 7 omits the acreage added by S. 59 to the Tolyabe and Inyo National Forests from determinations of the share of recelpts from the Twenty-five Percent Fund that exists between Californla and Nevada under the Act of May 23, 1908, provided, however, that the acreage added to these forests shall be counted in the distribution of the Twenty-five Percent Fund among affected counties in Nevads.

Section 8 would provide that nothing in the bill shall be construed to expand or diminish any water right of the United States under State or Federal law which the United States had, or may be determined to have had by purchase, reservation or otherwlse, prior to enactment of S. 59. Moreover, nothing in the bill would affect the right of the United States or of any person to acquire or dispose of water or water rights under applicable law. 
4

Section 9 of S. 59 would protect valid existing rights.

Section 10 would provide that administrative appeals, adjudications or reviews that are pending on the date of enactment would be completed by the Secretary of the Department in which they were initiated, except that the Secretary of the Department having jurisdiction over the land pursuant to this bill could exercise final administrative review. As a point of clarification, the reference to section 3 should be changed to section 4 .

S. 59 deals exclusively with lands in the State of Nevada transferring certain public lands presently administered by the Bureau of Land Management to the Forest Service and certain national forest lands to the Bureau of Land Management. The Administration has proposed a nationwide 1nterchange of lands between the Bureau of Land Management and the Forest Service. This proposal was submitted to the Congress on April 23, 1987. While S. 59 proposes to transfer the same lands within Nevada that are included within the Administration's broader proposal, it does not generate the savings and efficlencies that would result from the single natlonwide bill. Therefore, we recommend that the Subcommittee consider the nationwide proposal in lieu of S. 59 .

The Administration's proposal was developed after many months of careful and thorough consideration. To gain public input to the Interchange proposal, the Forest Service and BLM, on a multi-statè basis, conducted 85 public meetings in 1985; recorded over 600 consultations with Congress, interest groups, individuals, and government entities; and held a formal public comment period, including 30 public hearings. In addition, we conducted numerous meetings and 
discussions with congressional members snd staff to resolve 1ssues and concerns 1dentified since 1985. As a result of this process, the bill developed by the Administration would meet the purpose of this effort - to Increase efficlency of natursl resource management by merging orgsnizational units within the same geographic area, reducing personnel needs and duplication of offices, overhead, travel and adminlstrative functions. All of this would result in a reduction of costs to the government, representing a savings of 14 to 15 million dollars annually, and an 1mprovement of service to the public.

The goals stated in the S. 59 are similsr to those in the Administration's Nst1onwlde Interchange proposal. Unfortunately, ss 1t 1s written, S. 59 does not meet the goals or result in the benefits that a Nationwide Interchange bill would generate.

S. 59 does not provide for clear, orderly separation of administrative responsibilitles under the land laws. Questions remaln over several common land msnagement situations. One significant area that is not covered by S. 59 is the authorization and administration of lsnds under leases and patents issued pursuant to the Recreation and Public Purpose Act and existing applications for such lesses. Leases or pstents under the Recrestion and Public Purpose Act provide a msjor public benefit and are a maln source of lands to expsnding communities for important public services.

There are several Recreation and Public Purposes Act lesses, patents or applicstions for leases on the lands to be transferred to Forest Service administration under this b1ll. These lesses and patents provide such services as a county sponsored summer camp for troubled youth, church sites, 
6

school sites, several community parks and rural landfill sites. Under existing applications for a Recreation and Public Purposes Act lease are such proposals as a private youth camp, a state highway maintenance station, a county sewage treatment facllity, a jall, fire station and several school sites. Currently the Forest Service has no authority to administer this program to provide these services. S. 59 does not provide such authority. The Administration's nationwide proposal does provide authority for these activities.

Also S. 59 makes no provision for continuity of the land sale procedures, or for the treatment of pending applications for sales to local governments and private cltizens. There are existing proposals for sales which would exceed the present ability of the Forest Service to process and administer under the only authority to sell that they have -- the Act of January 22, 1983, that is popularly known as the Small Tracts Act. The Nationwide Interchange proposal provides for continulty in sales actions. It also provides for continuity of uses and authority for and protection of existing permits. If S. 59 is enacted, we suggest that provisions similar to these be included.

S. 59 is unclear on a variety of other matters, such as provisions for adopting the other agency's regulations, issulng joint regulations on similar programs administered by both Forest Service and BLM, title record responsibilities or severability of any provision within the Act. These activities are addressed in the nationwide proposal.

The adverse impact of S. 59 on consistent and comprehensive management within the State of Nevada and among other states needs to be emphasized because $1 t$ could be considerable. If the authorities to administer lands under which the 
7

Bureau of Land Mansgement operates are granted to the Forest Service for the two national forests covered by S. 59, those forests would be administered

differently than all other national forests. This situation would 1ikely lead to Inconsistencies in management within Nevada and elsewhere. For instance, the authority to handle Recreation and Public Purposes Act leases would not apply to other national forest lands. It would therefore be necessary for the Forest Service to develop regulations specific to just two of the 154 proclaimed national forests within the national forest system. The Administration's Interchange bill would clarify land entry, sales and withdrawal provisions on a nationwide basis, while also ensuring continuity in public service between national forests and public lands throughout and among states.

S. 59 would likely open the door to other state-by-state proposals for land exchange which might only lead to further inconsistencies in management procedures among states, if the individual interchange laws were not identical.

In summary, we support the concept of land adjustments between the Bureau of Land Management and the Forest Service. However, the findings in subsections 1 through 3 of section 1 of S. 59 and the objectives of the bill would be only minimally achieved. They could be achleved more effectively and efficiently on a multi-state basis. Transfers of land on an individual state basis as proposed by S. 59 do not provide a coherent approach to adjusting boundaries. Such adjustments should be on a broad-scale basis rather than on a state-by-state basis because of the probability that issues would be treated differently among states. Administrative juridiction and land holdings of the two agencles of ten cross State boundaries. Thus the most practicsl approach to sdjusting land ownership patterns is on a nstionwide basis which would allow fnterstate holdings to be adjusted. We still belleve that the 
8

Adminlstration's approach is approprlate and should be followed.

S. 59, as drsfted, may achieve limited benefits. However, the addition of other gtates with lands 1dentified for transfer between the Forest Service and the Bureau of Land Management would Improve public land management patterns and provide an opportunity for achleving some of the efficlencies, cost savings and public service Improvements identifled.

Under the Nationwide Interchange proposal, minerals authority would be transferred to the Forest Service. S. 59 does not have that provialon, nor do we belleve that it can be done on a state by state basis. Some of the savings Identified in the legislative analysis of the Natlonwide Interchange proposal were calculated on the basis of eliminating the need for both the Forest Service snd the Bureau of Land Management to visit the same aress when processing a varlety of applications.

S. 59 would result in no significant savings of personnel or administrative costs, and, as I sald, only minimal improvements in public service, since no offices would be affected. Some perwittees and other userg of the lands would simply deal with a different office and agency thsn they have in the past.

As I sald earlier, we recommend that Congress enact the natlonwide bill - the Admin1stration's Interchsnge proposal, Instead, as it would lead to more efficlent land management, Improved aervice to the public, and economic benefits in the administration of Federal landa. These goals can be attained and these are the reasons we continue to support the Interchange concept.

This concludes my statement. I will be pleased to respond to any questions. 
Senator Hecht. Thank you for summarizing.

As I said, if you want to leave, you are quite welcome to do so. If you want to wait until the panel is over with, that is fine, too.

Mr. BURFord. I will wait for the panel to finish.

Senator Hecht. Okay.

Mr. HorN.

\section{STATEMENT OF WILLIAM P. HORN, ASSISTANT SECRETARY FOR FISH AND WILDLIFE AND PARKS, DEPARTMENT OF THE INTE- RIOR}

Mr. HorN. Thank you, Mr. Chairman. I would just ask that the entire statement be inserted into the record, and I will present a summary of it.

Senator Hechт. Without objection.

Mr. HonN. Thank you.

I am pleased to present our views on S. 854 and state that we support its enactment. Let me add personally that I hope expeditious action can occur because the exchange would enable the U.S. Fish and Wildlife Service to acquire key in-holdings within two critical units of the National Wildlife Refuge System, the Lower Suwannee Refuge and the Key Deer Refuge, both in Florida.

As stated, the bill would authorize and direct the Department to exchange land in Nevada presently under BLM jurisdiction for wetlands in Dade County, Florida, owned by Aerojet.

Based on approved, professionally executed appraisals, the Federal Government is receiving more value than it gives up under this transaction. The bill would then subsequently authorize the Department to sell the Florida wetlands to the South Florida Water Management District. The funds received from this sale would be utilized for acquisition of in-holdings within the two previously mentioned wildlife refuge units.

We have been assisting Congress in preparing this legislation and the exchange contract that goes with it. In that process, we undertook environmental evaluations to ensure that our drafting efforts would not result in conflict with our responsibilities under the Endangered Species Act and other environmental laws.

Fortunately, there is a wealth of environmental data available on both parcels, particularly on the Coyote Springs Valley tract in Nevada, arising from the extensive studies done of the area in conjunction with its possible use as an MX missile site under the Racetrack Proposal of the prior Administration.

In addition, subsequent environmental analyses have also been prepared in this area.

We, on our own initiative prepared a Resource Ascertainment Report, which is similar to an environmental assessment to guide our activities. Lastly, we engaged in a formal, internal consultation under Section 7 of the Endangered Species Act, which resulted in the issuance of a "no jeopardy" opinion by the Fish and Wildlife Service.

All of this work provides a body of evidence that clearly indicates that the Aerojet activities in Nevada are expected to have no adverse effects on endangered, threatened, or other species of concern. 
The endangered species that are the focus of some concern are four species of fish that inhabit two sets of springs over 45 miles and 12 miles away from the water source at the lands Aerojet would obtain.

There are some concerns that groundwater extraction by Aerojet, in accordance with State law, I might add, may affect these springs. We are persuaded that such a possibility is remote, but have incorporated protective provisions in the contract to ensure that this remote and distant endangered species habitat will not be adversely affected by any activities Aerojet will engage in.

These are among many provisions built into the agreement to ensure avoidance of environmental damage and provide for mitigation of any damage which may occur.

The previous witnesses have mentioned, for example, the setaside of up to 18,000 acres of land for primarily a desert tortoise preserve to deal with that species, which is a species of some concern.

To provide an additional measure of protection, all of these environmental measures in the agreement will be incorporated into the land patent to ensure that these conservation measures will be binding on any future owners of the property should Aerojet ever sell the land.

The lands that the Department would acquire in Florida, as noted, are in Dade County and presently not of interest to either the Fish and Wildlife Service or the National Park Service.

However, the South Florida Water Management District, the State agency responsible for water conservation and management in southern Florida, is extremely interested in acquiring the property. They have provided us with a written offer to purchase should the property become available by passage of this legislation.

The sale of these lands to the water district would provide us with more than $\$ 2.4$ million of acquisition funds for use in the wildlife refuge units in Florida. I think it is safe to say that both the Lower Suwannee Unit and the Key Deer Unit are very important in terms of endangered species, such as the Manatee and the Key Deer, one of our most endangered mammals.

We would plan to use $\$ 1.65$ million of the proceeds created by this bill to acquire approximately 2,700 acres of in-holdings in the Lower Suwannee Unit, and the remaining approximately $\$ 700,000$ would be used to purchase tracts facing the imminent threat of development on Big Pine Key, an important habitat for the endangered Key Deer.

We are of the opinion that this legislation represents a very positive net benefit for all the parties. Nevada would receive environmentally sound development; Florida would receive an addition to its important water conservation system, and both Florida, the Nation, and the Fish and Wildlife Service would benefit from these important additions to the National Wildlife Refuge System.

Thank you.

[The prepared statement of Mr. Horn follows:] 
TESTIMONY OF WILLIAM P. HORN, ASSISTANT SECRETARY FOR FISH AND WILDLIFE AND PARKS, DEPARTMENT OF THE INTERIOR, BEFORE THE SUBCOMMITTEE ON PUBLIC LANDS, NATIONAL PARKS AND FORESTS, SENATE COMMITTEE ON ENERGY AND NATURAL RESOURCES, REGARDING S. 854 , AUTHORIZING AND DIRECTING THE SECRETARY OF THE INTERIOR TO EXCHANGE CERTAIN LANDS WITH THE AEROJET-GENERAL CORPORATION

June 30,1987

Mr. Chairman, I am William P. Horn, Assistant Secretary for Fish and Wildlife and Parks of the Department of the Interior. I am pleased to present our views on S. 854 , authorizing and directing the Secretary of the Interior to exchange certain lands in the States of Nevada and Florida with the Aerojet-General Corporation. We support the legislation.

At the request of Members of the Florida and Nevada Congressional delegations, we provided drafting services to them for preparation of the legislation, and for the draft implementing contract which we understand the Aerojet-General Corporation (Aerojet) has presented to the Committee.

S. 854 would authorize and direct the Secretary of the Interior to exchange approximately 51,710 acres of land in Nevada, presently under the jurisdiction of the Bureau of Land Management, plus mineral rights under 1,130 acres where Aerojet already owns the surface estate, for approximately 4,650 acres of wetlands in Florida owned by Aerojet. Based on approved appraisals, the Federal government is receiving slightly more value than it gives up. The Department is subsequently authorized to sell the Aerojet lands it would acquire in Florida to the South Florida Water Management 
District, and to enter into an interim agreement with the District for management of these lands prior to the finalization of the sale. Finally, S. 854 directs that the funds received from this"sale be utilized, without appropriation, for acquisition of additional lands at existing units of the National wildlife Refuge system within the State of Florida (i.e. Lower Suwannee and Key Deer).

Last year I testified before this subcommittee in support of the exchange proposal in principle, subject to extensive changes in the previous legislation (S. 2758, 99 th Congress). All of our concerns have been resolved in the legislation now before the subcommittee, although we do have two technical suggestions on matters which have just came to our attention.

As I am sure succeeding witnesses will explain in detail, Aerojet plans to utilize the lands it would acquire in Nevada for rocket testing and assembly work. This should contribute significantly to the Nevada economy. At the same time, we believe it would not have adverse environmental impacts.

We assisted in the preparation of the legislation and the implementing contract as a drafting service -- hence this is not a Departmental proposal. At the same time, we undertook environmental evaluations to ensure that our drafting the proposal would not result in conflicts with our responsibilities under the Endangered Species Act and other environmental laws. There is a wealth of environmental data available, particularly on the Coyote Spring Valley tract, arising from the extensive studies done of the area in 
conjunction with its possible use as an MX missile site under the "racetrack" proposal of the last Administration and from environmental analyses prepared by a contractor for Aerojet.

We prepared a Resource Ascertainment Report, similar to an envirommental assessment, utilizing this data, to guide us in our activities. In addition, we engaged in a formal internal consultation under Section 7 of the Endangered Species Act, which resulted in the issuance of a "no jeopardy" opinion by the Fish and Wildife service.

The evidence clearly indicates that the Aerojet activities in Nevada are expected to have no effect on endangered, threatened or other species of concern. The endangered species that are the focus of concern are four species of fish (the Pahranagat roundtail chub, White River springfish, Hiko White River springfish, and the Moapa dace) that inhabit two sets of springs over 45 and 12 miles, respectively, from the water source at the future Aerojet land at Coyote spring Canyon. There are some concerns that ground water extraction by Aerojet (in accordance with state law) might affect these springs. We are pursuaded that such a possibility is remote, but have incorporated provisions in the contract to ensure that this distant endangered species habitat will not be adversely affected.

There are extensive other provisions in the exchange agreement for avoidance of environmental damage and mitigation of any which may occur. For example, Aerojet at its expense will undertake to remove 
desert tortoises (a candidate species for listing under the Endangered Species Act) from contruction areas, and fence these areas, along with roads through high-density tortoise habitat, to minimize harm to tortoises from its activities. Moreover, nearly 18,000 acres of the exchange lands at coyote spring will be set aside as a wildlife preserve, primarily for the benefit of the tortoise. Aerojet will permit the Nevada Department of Fish and Game to maintain wildlife "guzzlers" (watering devices) on the land, and will pay for the installation of 10 additional ones by the state agency. Aerojet has committed to establish an Environmental Advisory Committee, of Federal, State, local and private experts, to advise them on all aspects of their operations on the exchange lands. Finally, these and other wildife protection measures will be incorporated into the patent we provide to Aerojet upon transfer of the land, thus ensuring that these conservation measures will be binding upon any future owners of the property should Aerojet at some point sell the land.

The lands the Department would acquire in Florida are immediately east of Everglades National Park, and were formerly the site of a rocket assembly plant. Because of their semi-developed nature, the National park Service has advised that these lands are not suitable for inclusion in the National Park System. However, the South Florida Water Management District (SFWMD), a state agency responsible for water conservation and management in southeastern Florida, is extremely interested in acquiring the property for water conservation purposes. They have provided us with a written offer to purchase, should the property become available by passage of this 
legislation.

In addition, Aerojet proposes to negotiate an agreement with the Water District giving it an option to purchase an additional 1600 acres of land at the exchange location if Aerojet determines it does not need the property for business purposes within the next few years. Facilitating SFWMD's water programs is of vital importance to the National Park Service since these programs are the centerpiece of efforts to restore natural sheet flows to the Everglades.

As previously noted, the lands have been appraised, and are of approximately equal value. The Nevada lands and mineral rights are valued at approximately $\$ 2,429,000$, and the Florida lands at approximately $\$ 2,441,000$. The United States will benefit by the approximately $\$ 12,000$ difference. Not all of the Nevada lands have been surveyed, and the legislation therefore provides for an interim conveyance of unsurveyed lands pending completion of a survey, to be conducted at Aerojet's expense.

In this connection, we suggest that the last sentence of section 2 (b)(2) of S. 845 be amended to provide that the lands shall, after the filing of an officially approved survey, be described in the patent by reference to the plat of survey. The use of an official survey will not only satisfy the statutory requirements for a "survey before patent", but will make it easier to protect any third-party rights that may have accrued on the lands involved in the exchange. 
The sale of the Florida lands to the Water District would provide us with more than $\$ 2.4$ million for acquisition of inholdings within existing National wildife Refuges in Florida. In this particular case we will not object to the provisions of Section 4 on the use of funds received. As a general rule, however, we have serious reservations with the automatic earmarking of receipts from the sale of Federal assets outside the budget and appropriation process. The Administration is now reviewing this matter to determine what conditions, if any, might warrant Administration support of any similar future proposals. Moreover, we suggest that te receipts be deposited in the Land and water Conservation Fund. The contributed funds account is used for donations from non-Federal sources and is not a proper account for receiving Federal receipts.

We have surveyed the needs in Florida, and find pressing use for this money at the Lower Suwannee National wildlife Refuge, on the Central Gulf Coast, and at the Key Deer National wildlife Refuge in the Florida Keys. The Lower Suwannee NWR ranks sixth nationally on the Fish and Wildife Service's Land and Water Conservation Fund priority list. It is one of the most diverse and productive wildlife areas in Florida. Six endangered and threatened species occupy the area. It provides essential nursery and feeding habitat for the Crystal River population of the manatee. The conversion of sizable areas within the timbered swamp and upland forest habitat protected by this Refuge is an imminent threat, with conversion to pine monoculture already underway nearby. 
If the legislation were passed with this provision intact we would utilize $\$ 1.65$ million to acquire 2,640 acres of wetlands there. This would be in addition to the $\$ 1.5 \mathrm{mill}$ ion appropriated last year for the lower Suwannee.

In addition, there are several smaller tracts within the authorized boundaries of the Key Deer Refuge facing the imminent threat of development. This Refuge is designed to protect the habitat of the endangered Key deer, although other endangered, threatened and "special emphasis" species, incluaing the manatee, the brown pelican, the white-crowned pigeon, the osprey and the mangrove cuckoo also utilize these areas. Habitat conversion for residential development is the primary threat here, and escalating development is blamed for a recent substantial drop in the deer population.

Although $\$ 2$ million was appropriated for acquisition at Key Deer NWR last year, some smaller tracts still need to be acquired and we would propose to utilize the remaining $\$ 700,000$ for this purpose.

We are pursuaded that this legislation would represent a net benefit for all parties. Nevada would receive much-needed environmentally sound development, which will provide jobs and an expanded tax base; Florida would receive an addition to its important water conservation system; and both Florida and the nation would benefit from the additions to the National wildlife Refuge system. We therefore support enactment of S. 854 . 


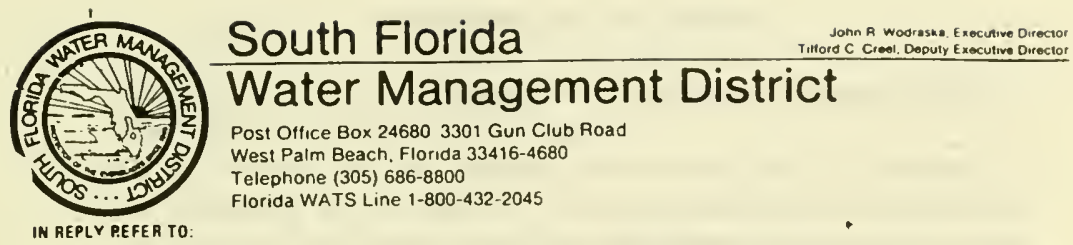

LM-SOR

C-111

Aerojet II

June 5,1987

Mr. William Swanson

U.S. Fish \& Wildlife Service

18 th and $C$ Streets

Washington, D.C. 20240

Dear Mr. Swanson: Bill

The enclosed agreement reflects the change from warranty deed to quitclaim deed, per our discussion with Oave Fisher of the solicitor's office. I believe you indicated that the remaining portion of the agreement was satisfactory.

Per our discussion, I understand that the subsurface abstracts wil be brought to date and sent to my office as early as possible for review. We believe that Aerojet owns all rights, except possibly for some rights held by the Trustees of the Internal Improvement Trust Fund.

Please contact me should any questions arise.

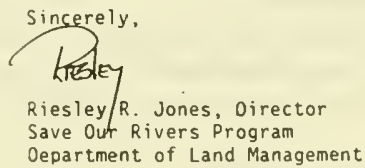

$R R J / I b$

Enclosure

CC: Alan Bonsack 
This Agreement made and entered into this day of

A. D., 1987, by and between the UNITED STATES OF AMERICA by and through the Secretary of the Interior or his authorized representative (hereinafter referred to as "Seller"), and SOUTH FLORIDA WATER MANAGEMENT DISTRICT, a public corporation of the State of Florida (hereinafter referred to as "Buyer").

For and in consideration of Ten $(\$ 10.00)$ Dollars aid cilict suus alid valuable consideration, the sufficiency and receipt of which is hereby acknowledged, and in further consideration of the terms and conditions hereinafter set forth, the parties hereto, intending to be legally bound, agree as follows:

\section{(1) AGREEMENT TO SELL AND BUY}

The Seller hereby agrees to sell to the Buyer and the Buyer hereby agrees to buy from the Seller, subject to the terms and conditions hereinafter set forth, that certain real property located in Dade County, Florida, described on the attached Schedule $A$. The final legal description may be changed by agreement between the Buyer and the Seller three months prior to closing of the agreement.

\section{(2) PURCHASE PRICE}

The purchase price is $\$ 525.00$ per acre for all of the lands and other interests, payable at time of closing, subject only to the prorations and adjustments as otherwise provided in this Agreement.

\section{(3) TIME FOR ACCEPTANCE}

If this Agreement is not executed by the Seller and the Buyer on or before September 30, 1987, the aforesaid deposit, if any, shall be, at the option of the Buyer, returned to him and this Agreement shall be null and void. The date of Agreement, for purposes of performance, shall be the date when the last one of the Seller and the Buyer have signed this Agreement. 


\section{(4) CLOSING DATE}

This Agreement shall be closed and the deed and possession shall be delivered on or before December 31, 1987; unless extended by other provisions of this Agreement.

\section{(5) PRORATIONS}

Taxes, and other expenses and revenue of said property shall be prorated as of the date of closing.

\section{(6) EVIDENCE OF TITLE}

Within thirty (30) days from the date of this Agreement, the Seller shall at its expense deliver to the Buyer or his attorney a title guarantee commitment issued by a qualified title insurer agreeing to issue to the Buyer upon the recording of the deed hereafter mentioned, as owner guarantee in the amount of the purchase price insuring the title of the Buyer to that real property, subject only to liens, encumbrances, exceptions or qualifications set forth in this contract and those which shall be discharged by the seller at or before closing. Buyer shall have fifteen (15) days from the date of receiving the evidence of title to examine same. If title is found to be defective, the Buyer shall, within said period notify the Seller in writing specifying the defects. If the said defects render the title unmarketable, the Seller shall have ninety (90) days from the receipt of such notice to cure the defects, and if after said period the Seller shall not have cured the defects, buyer shall have the option: (1) of accepting title as it then is or (2) declining to accept title and thereupon this Agreement shall be cancelled and the Buyer and the Seller shall have no claim against each other.

\section{(7) CONVEYANCE}

Seller shall convey title to the aforesaid property to the Buyer by quitclaim deed subject to matters contained in this Agreement and taxes for the year of closing. 


\section{(8) RESTRICTIONS AND EASEMENTS}

The Buyer shall take title subject to: (a) Zoning and/or restrictions and prohibitions imposed by governmental authority, (b) Restrictions and matters appearing on the plat and/or common to the subdivision, (c) Public utility easements of record, provided said easements are located on the side or rear lines of the property and are not more than six feet in width.

\section{(9) LEASES}

The Seller shall furnish copies of all written leases conveying the subject property to the Buyer 30 days prior to closing and if there are any persons in possession without written leases, estoppel letters from such persons specifying the nature and duration of the occupancy shall be furnished to the Buyer by the Seller prior to the closing date.

\section{(10) MECHANICS LIENS}

The Seller shall furnish to the Buyer an affidavit that there have been no improvements to the subject property for 90 days immediately preceding the date of closing. If the subject property has been improved within 90 days immediately preceding the closing date, the Seller shall deliver releases or waiver of all mechanics liens executed by general contractors, subcontractors, suppliers or material men and the Seller's mechanics lien affidavit.

\section{(11) PRORATION OF TAXES (REAL AND PERSONAL)}

Taxes shall be prorated based upon the current year's tax without regard to discount. If the closing takes place and the current year's taxes are not fixed, and the current year's assessment is available, taxes will be prorated based upon such assessment and the prior year's millage. If the current year's assessment is not available, then taxes will be prorated on the prior year's tax, provided, however, if there is completed improvement of the subject premises by January 1 of the year of closing, then the taxes shall be prorated to the date of closing 
based upon the prior year's millage and an equitable assessment to be agreed upon between the parties, taking into consideration Homestead Exemption, if any.

\section{(12) SPECIAL ASSESSMENT LIENS}

Pending, certified, confirmed or ratified special assessment liens as of the date of closing are to be paid by the Seller.

\section{(13) MAINTENANCE}

Eetresc: the ditc of the i., c.ent $a$. $c$ the date of clcsilig, the property, shall be maintained by the Seller in the condition as it existed as of the date of the Agreement, ordinary wear and tear excepted.

\section{(14) HANDWRITTEN PROVISIONS}

Handwritten provisions mutually agreed to by both Buyer and Seller and inserted in this Agreement shall control all printed provisions in conflict therewith.

\section{(15) OTHER AGREEMENTS}

No agreements or representations, unless incorporated in this Agreement shall be binding upon any of the parties.

\section{(16) SPECIAL CLAUSES}

a) This contract is subject to an appraisal which shall be updated, prior to closing which shall justify purchase price for the Buyer.

b) Buyer agrees and acknowledges that the property is to be used accordingly with those uses set forth in the Florida Resource Rivers Act Section 373.59 Florida Statutes.

c) Buyer has evaluated the resource value of this property and has determined that acquisition will enhance the water management objectives of the Buyer. 


\section{(17) DOCUMENTS FOR CLOSING}

The Buyer's attorney shall prepare the deed, the Seller's affidavit, and the closing statement and submit copies of the same to the seller's attorney, at least seven (7) days prior to scheduled closing date.

\section{(18) EXPENSES}

State and County surtax and documentary stamps which are required to be affixed to the instrument of conveyance and intangible personal property taxes shall be paid by the Seller.

\section{(19) DEFAULT BY BUYER}

If the Buyer fails to perform any of the covenants of this Agreement, all money paid pursuant to this Agreement by the Buyer as aforesaid shall be retained by or for the account of the Seller as consideration for the execution of this Agreement and as agreed liquidated damages and in full settlement of any claims for damages.

\section{(20) DEFAULT BY THE SELLER}

If the Seller fails to perform any of the covenants of this Agreement. the aforesaid money paid by the Buyer at the option of the Buyer, shall be returned to the Buyer on demand: or the Buyer shall have the right of specific performance.

\section{(21) PLACE OF CLOSING}

Closing shall be held at the office of the Buyer's attorney or as otherwise agreed upon.

\section{(22) TIME IS OF THE ESSENCE}

Time is of the essence of the Agreement for Sale and Purchase.

\section{(23) RISK OF LOSS}

The seller further agrees not to do, or suffer others to do, any act by which the value or title to said lands may be diminished or encumbered. It is further agreed that any loss or damage occurring prior to the vesting of satisfactory title in the Buyer by reason of the unauthorized 
cutting or removal of products therefrom, or because of fire, shall be borne by the Seller; and that, in the event any such loss or damage occurs, the Buyer may refuse, without liability, to accept conveyance of said lands, or the Buyer may elect to accept conveyance, upon an equitable adjustment of the purchase price.

\section{(24) RIGHT OF ENTRY}

The seller further agrees that during the period covered by this instrument officers and accredited agents of the Buyer shall have at all proper times the unrestricted right and privilege to enter upon said lands for all proper and lawful purposes, including examination of said lands and resources upon them.

\section{(25) NOTICE}

It is mutually understood and agreed that notice of acceptance of this agreement shall be given to the Seller by certified mail addressed to the Secretary of the Interior, or his authorized representative, United States Department of the Interior, Fish and Wildife Service, washington, D.C., 20240, and shall be effective upon date of mailing and shall be binding upon the Seller.

\section{(26) ADOITIONAL OPTION}

It is mutually agreed that this Agreement for the Purchase of lands shall be subject to Aerojet General Corporation granting an option to purchase to the South Florida Water Management District to approximately 1,560 acres of the remaining lands. This separate option will have the following terms:
a) Price: \$525/acre for fee simple title.
b) Date of operability: Seven (7) years from date of closing of the subject transaction with the vendor unless the tract is being used for national security purposes.
c) Aerojet General Corporation may reserve severable use rights, if any.
d) Type of deed: General Warranty Deed. 
The Secretary of the Interior, acting by and through his authorized representative, as the Seller, has executed this agreement on behalf of the United States of America on this the day of 1987.

THE UNITED STATES OF AMERICA

ATTEST:

By:

(Title)

The Chairman of the South Florida Water Management District has executed this agreement on behalf of the Buyer on this the day of , 1987.

SOUTH FLORIDA WATER MANAGEMENT

OISTRICT, BY ITS GOVERNING BOARO

ATTEST :

By: 
AEROJET-GENERAL CORPORATION LANDS TO BE EXCHANGED TO UNITED STATES FISH AND WILDLIFE SERVICE DADE COUNTY, FLORIDA

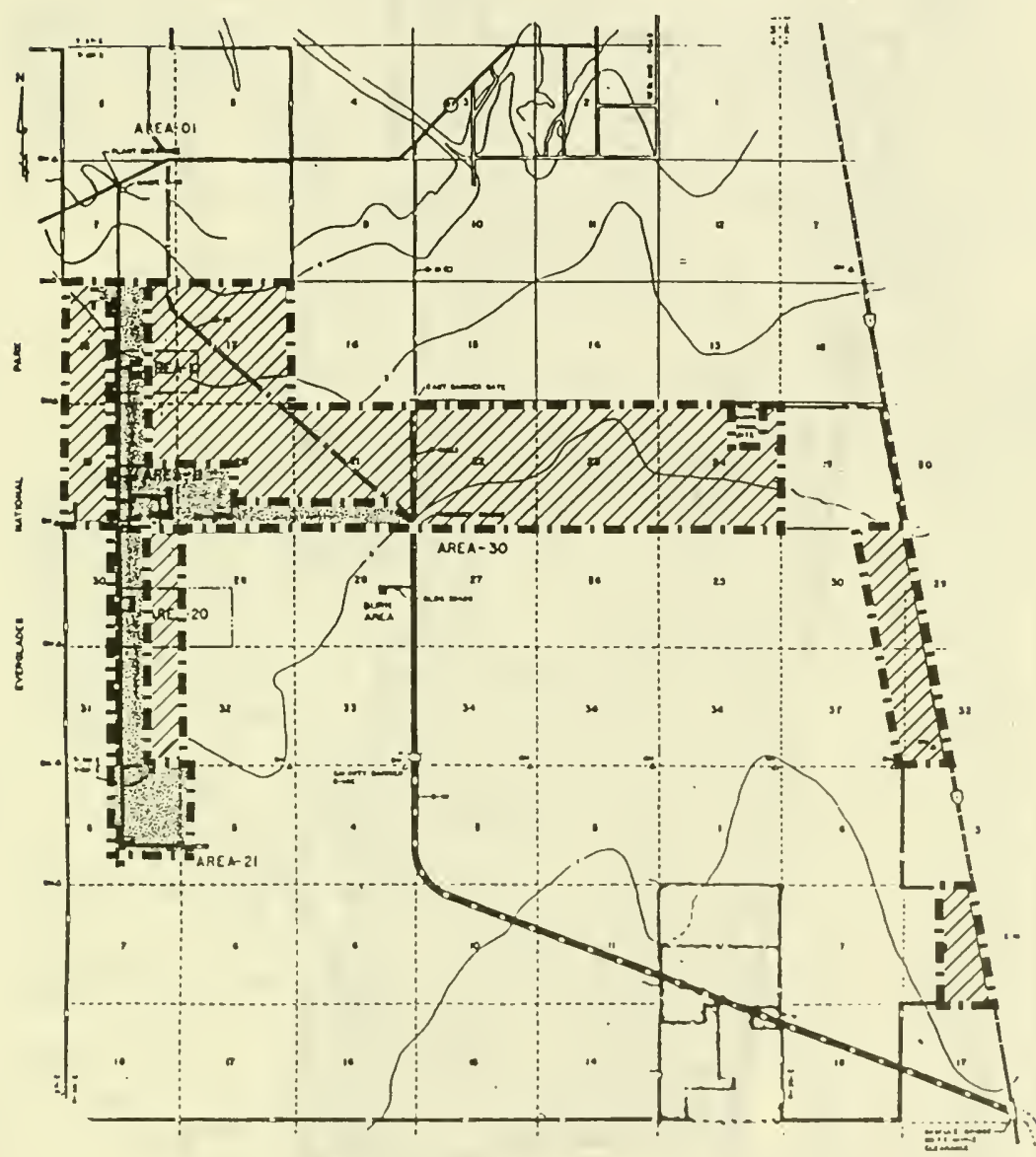

" $/ / /$, lands to be exchanged LANDS TO BE RETAINED

FEBRUARY 1987 
PUBLIC DOMAIN LANDS TO BE EXCHANGED TO AEROJET-GENERAL CORPORATION CLARK AND LINCOLN COUNTIES, NEVADA

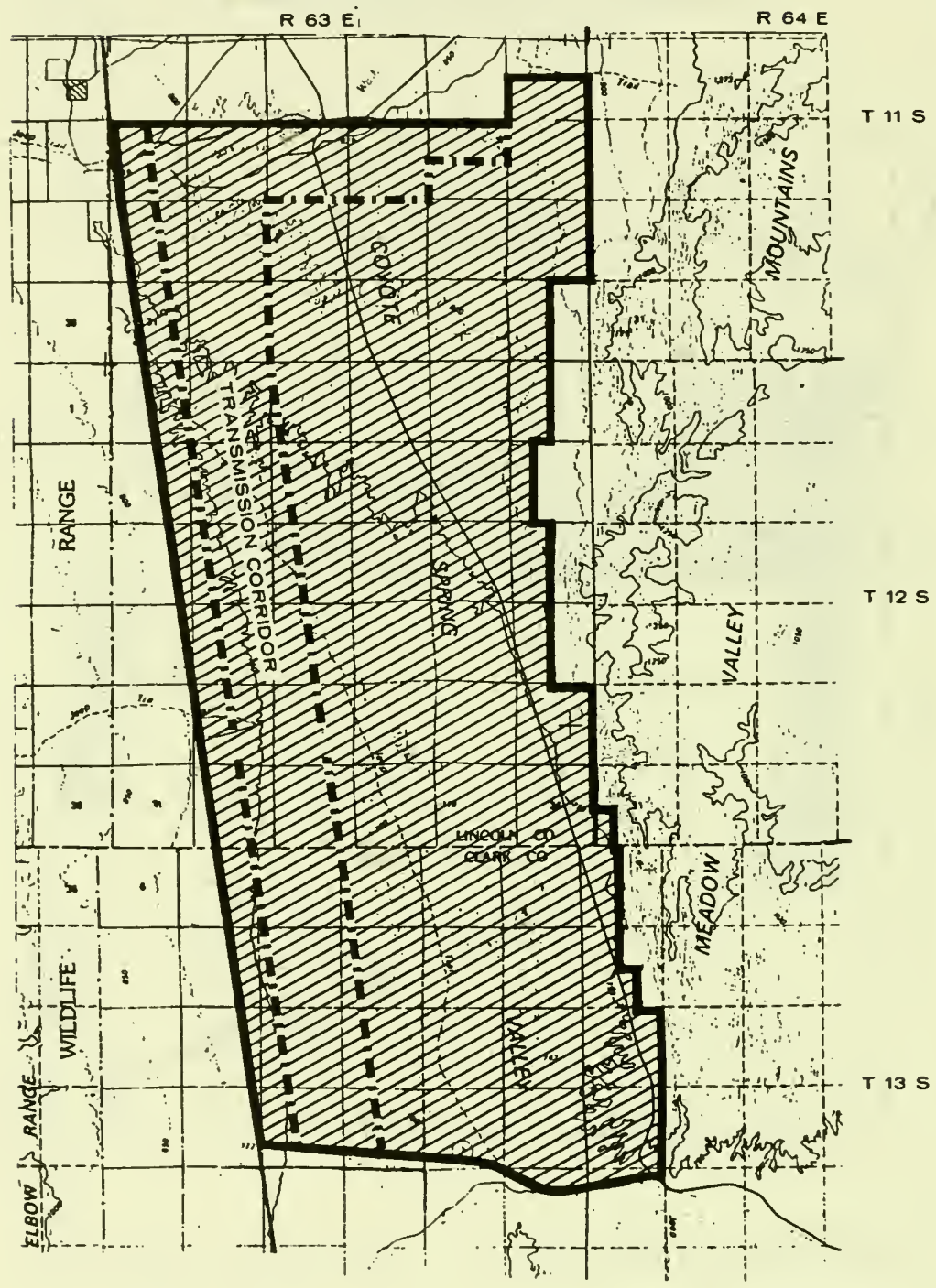

FEBRUARY 1987 
PUBLIC DOMAIN LANDS TO BE EXCHANGED TO AEROJET-gENERAL CORPORATION MINERAL COUNTY, NEVADA

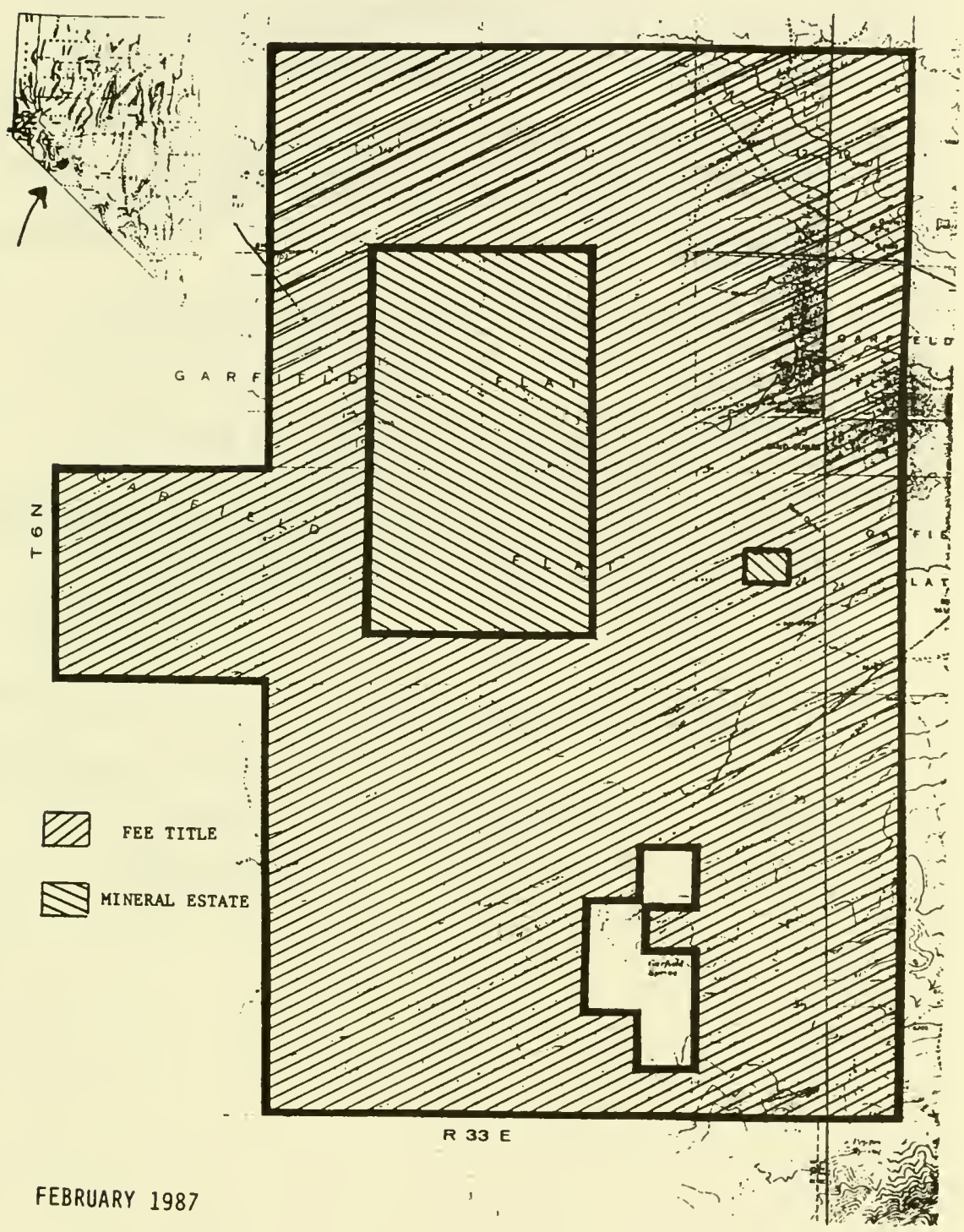


The Lower Suwannee National Wildlife Refuge was established on April 10, 1979, to preserve 57,000 acres of unique and significant fish and wildlife habitat within the lower Suwannee River floodplain. The major habitat types within the proposed area include tidal salt marsh, timbered swamp, hardwood hammock, oine flatwoods, fresh marsh, wet prairie, and open water.

The significant habitat within the proposed area is utilized by a wide variety of fish and wildlife species. Nongame marsh and water birds, along with resident and wintering waterfowl including black ducks, redhead ducks, mallards, and wood ducks are present on the area seasonally or year-round. Six endangered and threatened species are known to exist on the area including the West Indian manatee, the bald eagle, the green sea turtle, the American alligator, and the Eastern indigo snake.

Notably, the refuge provides essential nursery and feeding habitat for the Crystal River population of the West Indian manatee. This unique aquatic mammal is reported to inhabit some of the springs of the Suwannee River during the winter months.

The conversion of sizable areas of the timbered swamp and upland forest for residential, commercial, and recreational developments is an imminent threat to the Gulf Coast north of Cedar Key. Conversion to agriculture and, more importantly, pine monoculture has already begun and can be expected to increase. The coastline developments and the increased public use of the marshes, salt water areas, and the Suwannee River itself would cause a substantial reduction in available wildlife habitat and an increase in disturbance and harassment of wildife using the refuge area. 
LWCF FY 1988

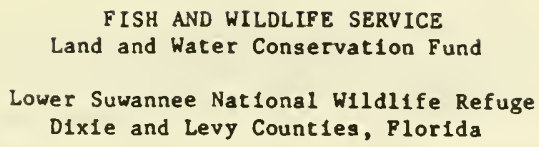

ACQUISITION AUTHORITY

LOCATION

APPROPRIATIONS
: Fish and Wildlife Actr of 1956, as amended

: On the Gulf of Mexico approximately 50 miles southwest of Gainesville, Florida

$\begin{array}{lr}\text { FY } 1979 & \$ 1,250,000 \\ \text { FY } 1980 & 850,000 \\ \text { FY } 1981 \text { resc1ssion } & -287,000 \\ \text { FY } 1983 & 1,500,000 \\ \text { FY } 1984 & 2,000,000 \\ \text { FY } 1985 & 3,381,000 \\ \text { FY } 1986 & 2,378,000 \\ \text { FY } 1987 & 1,500,000^{\star} \\ \text { Total Appropr1sted } & \$ 12,572,000 \\ & \\ & \end{array}$

ACQUISITION STATUS

Acquired thru FY 1986

Planned FY 1987

Remalning

Total

PURPOSE OF ACQUISITION

CONGRESSIONAL DELEGATION

\begin{tabular}{|c|c|c|c|}
\hline Ownersh1p & Acres & Cost ${ }^{\star}$ & $\begin{array}{l}\text { Per } \\
\text { Acre }\end{array}$ \\
\hline 9 & 35,620 & $\$ 8,872,000$ & $\$ 249$ \\
\hline $\begin{array}{r}5 \\
10 \\
\end{array}$ & $\begin{array}{r}12,360 \\
8,798 \\
\end{array}$ & $\begin{array}{r}3,700,000 \\
3,145,000 \\
\end{array}$ & $\begin{array}{r}299 \\
350 \\
\end{array}$ \\
\hline 24 & $\overline{56,778}$ & $\overline{\$ 15,717,000}$ & $\overline{\$ 277}$ \\
\hline
\end{tabular}

Represent at Ives

Detret

B111 Grant, (R)

Lawt on Chiles, (D)

Bob Graham, (D) 
The National Key Deer Refuge was established August 22, 1957, by Public Law 85-164,-for the purpose of protecting and maintaining habitat extensively used by the endangered key deer. Acquisition of the refuge has been a fragmented, on-going operation since the refuge was established.

Preservation of the major habitats for the endangered key deer via acquisition contributes to the overall faunal diversity of Florida and the Nation. No Name Key and Big Pine Key are the two most extensively used Keys in the range of the key deer. Several other $r$ are, endangered, and "special emphasis" species are also found here including the white-crowned pigeon, the mangrove cuckoo, the osprey, the brown pelican, the West Indian manatee, and the American alligator.

The greatest threat to key deer habitat in this area is habitat modification, with its resulting canals, land clearing, and subsequent increases in road and dog kills. Developments will continue to escalate when utility lines are constructed. Non-residents, as well as residents, are also a threat to habitat degradation or destruction due to activities such as trash dumping, trail-biking, plant collecting, and wood cutting. This habitat alteration is the apparent reason behind the deer population . decline from 350 in 1982 to 250 in 1983. Habitat must be protected to preserve the integrity of the subspecies within its range.

Acquisition of No Name Key is identified and recommended in the Fish and Wildlife Service concept plan entitled Significant Wildife Resource Areas of Florida. Preservation of the No Name Key area will contribute to the long-term stability of the unique key deer population and other important wildlife species as well. 


\section{FISH AND WILDLIFE SERVICE \\ Land and Water Conservation Fund \\ Key Deer \\ National Key Deer Refuge \\ Monroe County, Florida}

ACQUISITION AUTHORITY

LOCATION

APPROPRIATIONS
: Endangered Species Act

: Florlda Keys

: FY 1968

FY 1973

FY 1981

FY 1981 resc1ssion

FY 1984

FY 1985 reprogramming

FY 1985

FY 1986

FY 1987

Total Appropriated

$\$ 1,797,637$

178,000

$2,000,000$

$-73,000$

$2,000,000$

100,000

$2,450,000$

$1,903,000$

$2,000,000^{*}$

\$12,355,637

* 788,000 Proposed for rec1ssion

\section{ACQUISITION STATUS}

Acquired thru FY 1986

Planned FY 1987

Rema1ning

Total

PURPOSE OF ACQUISITION

CONGRESSIONAL DELEGATION

\section{Representatives}

Danie B. Fascell, (D)

\section{District}

19

Lawt on Chiles, (D)

Bob Grahan, (D) 
Senator Hecht. Thank you very much.

Mr. Leonard.

STATEMENT OF GEORGE M. LEONARD, ASSOCIATE CHIEF, FOREST SERVICE, DEPARTMENT OF AGRICULTURE

Mr. LeONARD. Mr. Chairman, thank you very much. We are happy to be here to give you the views of the Department of Agriculture on S. 59 .

S. 59, as discussed by Director Burford, provides for substantially the same transfer of lands within the State of Nevada as would be done in the National Interchange Proposal that the Forest Service and BLM have submitted; and, as such, we think that those transfers within the State of Nevada are desirable.

However, we would much prefer that those transfers take place within the context of a national, or at least a regional Interchange bill, because of the very substantial public benefits that would accrue thereto.

That, I think, completes my statement.

[The prepared statement of Mr. Leonard follows:] 
STATEMENT OF

GEORGE M. LEONARD, ASSOCIATE CHIEF

FOREST SERVICE

UNITED STATES DEPARTMENT OF AGRICULTURE

before the

Subcommittee on Public Lands, National Parks and Forests

Committee on Energy and Natural Resources

United States Senate

Concerning S. 59 and S. 854

June 30, 1987

MR. CHAIRMAN AND MEMBERS OF THE SUBCOMMITTEE:

Thank you for the opportunity to present our views on both S. 59 and S. 854 . Both of these bills involve lands within the State of Nevada. S. 854 does not involve any land managed by the Forest Service. Therefore, the Department of Agriculture defers to the Department of the Interior on S. 854.

S. 59, the "National Forests and Public Lands of Nevada Enhancement Act of 1987." would interchange land management functions between the Bureau of Land Management and the Forest Service within the State of Nevada. The Department of Agriculture strongly recommends enactment of the Administration's proposal for a nationwide interchange between these two agenciea in preference to S. 59.

S. 59 would transfer approximately 511,000 acres of public lands administered by the Bureau of Land Management in Nevada to the Forest Service. Most of the lands that would become National Forest System lands are located in the Spring Mountains, which are adjacent to the Las Vegas Ranger District of the Toiyabe National Forest. Other lands to be transferred to Forest Service management are in the eastern Sierras. They involve the Tolyabe and Inyo National 
Forests. S. 59 would also transfer 23,000 acres of National Forest System lands administered by the Forest Service to the Bureau of Land Management. These lands are in the eastern Sierras within the Toiyabe and Inyo National Forests. (Refer to Map Display.)

S. 59 would require that the transferred land be managed under the current plans in effect at the time of transfer. This situation would continue until the plans are revised under the planning authorities of the agency managing the land at that time. The bill further provides that existing valid water rights and other outstanding rights would not be expanded upon or diminished by the land transfer and affirms that new, reserved water rights would not be created by its enactment.

With respect to the transfer of land, S. 59 is the same as the Nevada portion of the Bureau of Land Management/Forest Service (BLM/FS) interchange proposal. However, S. 59 lacks the nationwide initiatives; it would not result in the same savings and efficiencies as would the national proposal, for example, the transfer of mineral management functions to the Forest Service. We strongly recommend enactment of the overall BLM/FS interchange as explained in the Record of Decision for the Legislative Environmental Impact Statement transmitted to the Congress in Febmary of 1986 and again earlier this year. We support the specific actions proposed by S. 59 if done within the framework of a National proposal rather than through the concept of individual State interchanges.

This concludes my prepared testimony. I would be pleased to answer questions that the members of the Subcommittee may have. 
Senator Hеснт. Well, I have never had such a fine day with government witnesses in my life. I have been here for five years. It is amazing what that box does [indicating].

[General laughter.]

Senator Hecht. Thank you. Your full statement will be in the record.

Mr. LeONARD. Thank you.

Senator HeCHT. Mr. Bok.

STATEMENT OF ERIK BOK, FEDERAL LEGISLATIVE REPRESENTATIVE, LOS ANGELES DEPARTMENT OF WATER AND POWER, LOS ANGELES, CA

Mr. BoK. Thank you, Senator Hecht.

Senator Hechт. Let me first say to those who might not know you that these gentlemen are well known. You are the Federal Legislative Representative, Los Angeles Department of Water and Power, Los Angeles, California.

Mr. BoK. Yes.

L.A. Water and Power is the project manager for the Intermountain Power Project in Utah and the White Pine Power Project, which is proposed to be built in White Pine County, Nevada.

I would like to thank the Subcommittee for allowing me to speak on S. 854.

IPP and the White Pine Power Project are two separate 1,500 megawatt coal-fired power plant projects. IPP is a $\$ 5.5$ billion generating station located in Millard County, Utah. The IPP generating station became fully operational in May of 1987.

The White Pine Power Project is a proposed generating station and, as I mentioned, would be located in White Pine County, Nevada.

As introduced, S. 854 does not explicitly preserve the existing IPP and White Pine Power Project rights of way interest in the Coyote Springs area of the Nevada portion of the proposed land exchange.

In order to protect those interests, there is a need to set aside a transmission line corridor in the land slated for acquisition by Aerojet General Corporation.

The IPP and White Pine Power Projects would be seriously damaged should a transmission line corridor not be expressly reserved in the legislation.

Both these projects have gone through an extensive EIS process and in 1980, the Intermountain Power Project transmission line was granted a right of way, and the White Pine Power Project in 1985 was granted a record of decision in support of transmission corridors in the same area.

The Coyote Springs area is a critical link for energy transmission between southern and northeastern Nevada. Due to the topographical features of the terrain and environmental constraints-there are several wilderness study areas around the property-and legislative mandates for uses of the area for military uses, no feasible alternative routes exist for this area.

Our involvement with BLM on establishing a transmission line corridor throughout the Coyote Springs area dates back to the late 
1970 s, and since that time, we have spent considerable time and money to route or actually to site the feasibility of a transmission corridor to the land.

Fortunately, Aerojet has worked with us in the last couple of months to address this issue, and recently we have reached an agreement along with the Department of the Interior and Nevada electric utilities to preserve via a proposed amendment a corridor in these lands. The amendment will assure, one, that Aerojet's land use objectives are going to be met; two, that the critical NorthSouth energy transmission link will be available; and, three, that the interests of the Intermountain Power Project and the White Pine Power Project have for themselves will be preserved. We believe that all interests will be accommodated if the Subcommittee amends the bill to preserve the electric transmission corridor in the Coyote Springs area, using our jointly drafted, amended language.

It is essential that a one-mile wide transmission corridor throughout the Coyote Springs area be reserved in the legislation for the proposed land exchange.

Both the Intermountain Power Project and the White Pine Power Project were evaluated for feasibility based on the use of this transmission line corridor. The rights of way have already been agreed to by BLM, and we feel that losing it will create a major hardship for the project participants who expended the time and energy to comply with the extensive need for the requirements.

That ends my statement.

We have submitted a written statement to the Committee and would like for that to be entered into the record.

Senator Hecht. Without objection.

Mr. BoK. The witness statement contains the amendment.

[The statement follows:] 


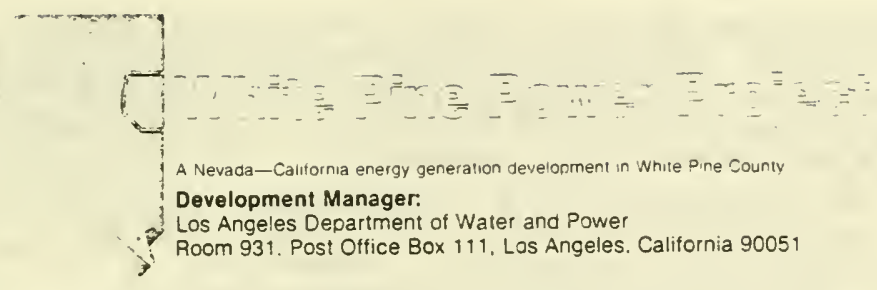

Testimony on S. 854 on Behalf

of the Los Angeles Department of Water and Power Before the Senare Public Lands, National Parks and Forests Subcomittee of the Energy and Natural Resources Committee

\author{
by \\ Eldon A. Cotton \\ Assistant Chief Engineer - Power
}

June 24,1987

Mr. Chainman, the Los Angeles Department of Water and Power (LADWP) appreciates the opportunity to submit for the record testimony regarding the proposed 51,710 -acre exchange of public land in Clark County and Lincoln County, Nevada, for 4,660 acres of land in Florida. The LADWP's concerns relate specifically and only to electric transmission corridors within the Nevada land to be exchanged. This potential exchange would seriously impact the two proposed white Pine Power Project (WPPP) transmission lines, the Intermountain Power Project (IPP) Line 2, and the Western Area Power Administration Inland Intertie Project, as well as result in closure of the major north-south utllity transmission corridor in eastern Nevada.

One of the projects that would be adversely affected by the proposed land exchange is the WPPP. The WPPP is a proposed 1500 megawatt coal-fueled generating facility and associated transmission lines to be located in eastern Nevada to help meet the future electrical needs of Nevada and California residents.

The White Pine County community is a strong proponent for the WPPP. Community participation throughout the WPPP development phase has been instrumental in creating a project that will have a positive social and economic impact on white Pine County. The construction and operation of this $\$ 2.5$ billion project would result in significant economic benefits to white Pine Councy and the State of Nevada. LADWP, as Development Manager for the WPPP, has been working with the Bureau of Land Management (BLM), as Lead Agency, since 1980 on the routing and environmental assessment of corridors from the proposed $1 P P P$ site in White Pine County, Nevada, to southern Nevada. The WPPP participants have expended approximately $\$ 23.5$ million to date on the Project development 
As required by Section 102 of the National Environmental Policy Act (NEPA) for major Federal actions significantly affecting the quality of the human enviroment, the BLM and LACWP consulted with aumerous federal and state regulatory agencies and interested parties in preparation of the WPPP Environmental Impact Statement (EIS), a detailed statement which assessed:

(i) the environmental impact of the proposed action;

(ii) any adverse environmental effects which cannot be avoided should the proposal be implemented;

(iii) alternatives to the proposed action;

(iv) the relationship between local short-term uses of man's environment and the maintenance and enhancement of long-term productivity; and

(v) any irreversible and irretrievable commitments of resources which would be involved in the proposed action should it be implemented.

Public hearings to assure full public participation in the NEPA environmental assessment process for the WPPP were held throughout the State of Nevada, with public comments being received and considered before the EIS was inalized.

The WRPP preferred electric transmissicn corridor (Attachment 1), which is described in the WPPP Final EIS, is located directly north of and through the area proposed for withdrawal, and is the critical utility corridor linking northeastern Nevada with southern Nevada. The WPPP preferred electric transmission corridor, although tightly constrained by the Delamar Mountains Wilderness Study Area (WSA) to the west and by the Meadow Valley Mountains WSA to the east (Attachment 2), is sufficient to route all of the electric transmission lines currently being considered.

The alternative to the preferred segment is located near the Pahranagat Wildiffe Refuge and is also severely constrained by WSA boundaries under federally mandated WSA restrictions. The alternative electric transmission corridor segment, previously evaluated by the BLM for the second Intermountain Power Project electric transmission line, has insufficient capacity to accommodate more than one of the several electric transmission lines proposed for routing through this area.

The proposed land exchange that would result from the passage of S. 854 would preclude the use of the WPPP preferrea and alternative electric transmission line corridors and would eliminate the path for transmission of electricity irom WPPP or the other known electric eransmission line projects proposed for routing through this area.

The above concerns were conveyed to the U.S. Fish and Wildilie Service (USFWS) by letter dated August 18, 1986 (Attachment 3). To date, USFWS has not provided any provisions for allowance for issuance of rights-of-way for WPPP corridors within the land to be exchanged. In adaltion, S. 854 does not contain any provisions 
for previously evaluated corridors. The LADWP has offered to the U.S. Department of the Interior, by letter dated November 5, 1985 (Attachment 4), to exchange the LADWP-owned Corral Canyon property located in the Santa Monica Mountains Recreational Area for BLMmanaged property, including land in this area, needed for the WPPP. In response to the introduction of $\mathrm{S} .854$, a letter was sent to the Secretary of the Interior dated September 18, 1986 (Attachment 5) by the WPPP stating its concerns about the impacts on the electric transmission corridor relative to the proposed land exchange.

We have been working diligently with Aerojet, the Department of Interior and other interested Nevada electric utilities to resolve this issue since september of 1986. After extensive negotlations Aerojet, Nevada electric utilities, and IADWP have drafted an amendment to S. 854 (Attachment 6) which wlll assure (1) Aerojet's land use objectives will be met, (2) that critical north-south energy transmission link will be available for future growth, and (3) the IPP and WPPP electric transmission rights will be reserved.

We believe that all interests will be accomodated if the subcommittee amends the bill to preserve the electric transmission corridor in the coyote springs area using our jointly drafted amendment language. It is essentlal that a one-mile-wide transmission line corridor through the coyote springs area be reserved in the legislation for the proposed land exchange. Both the IPP and WPPP were evaluated for feasibility based upon use of this transmission line corridor. The rights-of-way have already been agreed to by BLM and we feel that losing it will create a major hardship on the project participants who have expended millions of dollars complying with the National Environmental Policy Act (NEPA) environmental process.

Attachments 
Attacnmenc $\mathbf{1}$

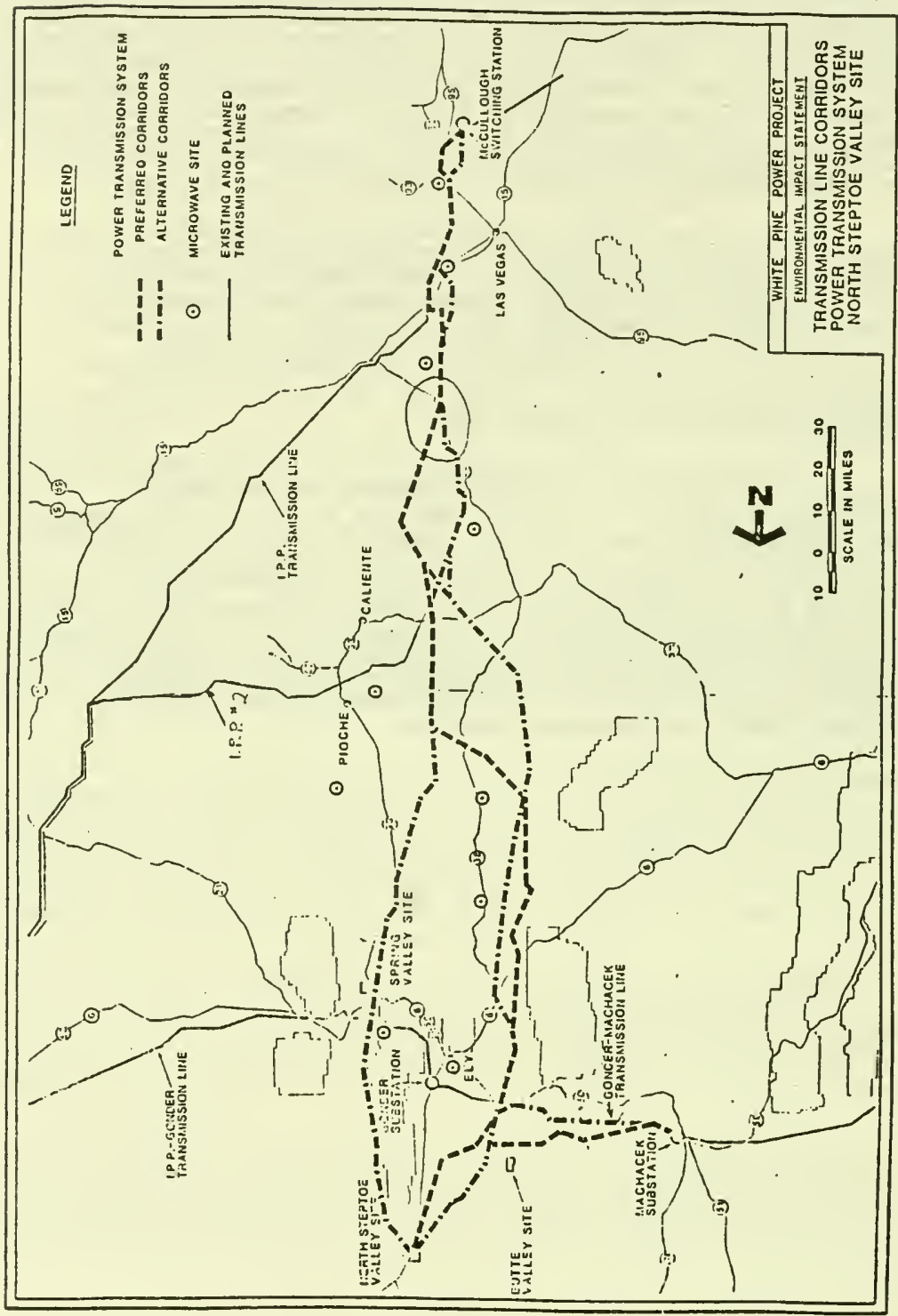




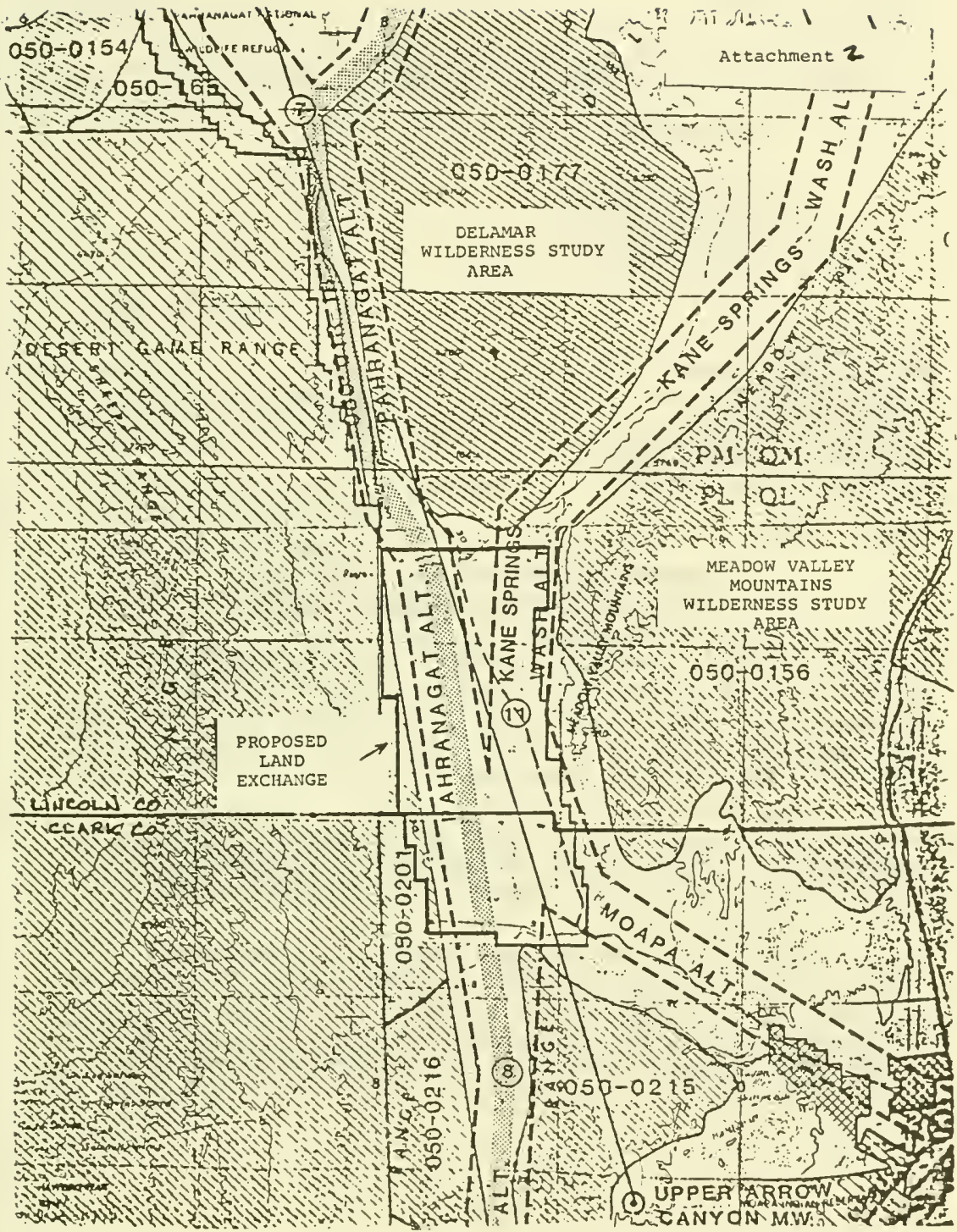


Mr. William P. Horn

United States Fish and Wildlife Service Department of the Interior 18 th and C streets, N.W. washington, D.C. 20240

Dear Mr. Horn:

\section{Proposed Withdrawal of Public Lands Clark and Lincoln Counties, Nevada}

This is to state the concerns of the Los Angeles Department of Water and Power (LADWP), acting on behalf of the White Pine Power Project (WPPP) and the Intermountain Power project (IPP), regarding the proposed 45,298-acre withdrawal and reservation of public lands in Clark and Lincoln Counties, Nevada. These concerns relate to electric transmission corridors through these lands proposed for withdrawal.

The WPPP and the IPP have completed the federal environmental licensing phase with IPP having just completed construction of one of two of the project's transmission lines. Both projects have approved transmission corridors through the proposed withdrawal area.

The area of the proposed withdrawal is extremely critical from a utility planning viewpoint in that it represents a transmission corridor window created by military reservations, the Desert Wildlife Refuge, and several wilderness study areas. We respectfully request consideration of these two projects' transmission facilities and would like to meet with you to discuss our concerns prior to introduction of legislation authorizing the exchange. 
If additional information is needed, or to schedule a meeting, please contact Mr. Edvard Karapetian at (213) 481-3250. sincerely.

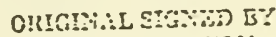
ELLUN A. Ci):?0:iksm ELDON A. COTTON Assistant Chief Engineer - Power

cc: Aerojet General Corporation

Corporate Headquarters

10300 North Torrey Pines Road

La Jolla, California 92037

Mr. Edward F. Spang, Director

Bureau of Land Management

P.O. Box 12000

Reno, Nevada 89520

Mr. Edward Karapetian 
Attachment 4

November 5, 1985

Mr. Robert N. Broadbent

Assistant Secretary for Water and Science

U.S. Department of the Interior

Interior Building

Washington, D. C. 20240

Dear Mr. Broadbent:

\section{Corral Canyon Land Exchange}

Several months ago we discussed the possibility of a 1 and exchange between the Federal Government and this Department. Recently, Mr. Eldon Cotton agreed to furnish you with additional information regarding property which might be involved in the exchange.

The property owned by this Department, which may be available for exchange with the Federal Government, is located within the Santa Monica Mountains National Recreational Area. The property consists of approximately 98 acres, and we estimate its fair market value in the neighborhood of $\$ 2$ to $\$ 3 \mathrm{mill}$ ion. We would be interested in discussing the exchange of this property for land of equal value suitable for the location of power generation and transmission facilities. Enclosed are Figures 2-7, 2-17, and 2-19 that identify properties needed by the White Pine Power Project that we would be interested in exchanging for the Corral Canyon site. These properties include $325 \mathrm{miles}$ of transmission corridor in a 330-foot $r$ ight-of-way (Figure 2-7), Federal lands within the $86-\mathrm{mile}$-long preferred railroad corridor (Figure 2-17), and the 2,250-acre North Steptoe Valley Site (Figure 2-19). Other properties associated with the White Pine Power Project could include well fields and microwave sites. I have also enclosed for your use a map of the Santa Monica Mountains National Recreational Area, with the Corral Canyon site identified in red. I an sure support would be expressed by the California Congressional Representatives for adding the Corral Canyon property to the National Recreational Area, and 1 am sure supporters of the White Pine Power Project would favor our acquisition of the land needed for that Project. 
I would be glad to meet with you and other Interior representatives to discuss this matter further. If you require additional information or would like to schedule a meeting. please contact me at (213) 481-5651 or Mr. Cotton at (213) 481-3203.

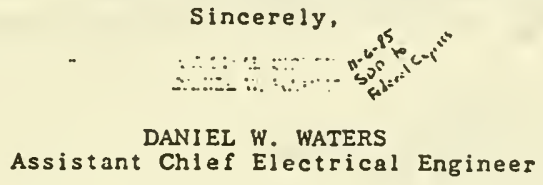

Enclosures (4)

cc: Mr. Eldon A. Cotton w/encls. 
A Nevada-Calitornia energy generation development in White Pine Counry Development Manager.

Los Angeles Department of Water and Power

September 18, 1986

Room 931, Post Olfice Box 111, Los Angeles. Calitornı 90051

Mr. Donald P. Hodel

Secretary of the Interior

U.S. Department of the Interior

18 th and C Streets, N.W.

Washington, D.C. 20240

Dear Mr. Hodel:

Proposed Withdrawal of Public Lands

clark County and Lincoln County. Nevada

This letter is to state the concerns of the Los Angeles Department of Water and Power (LADWP). Development Manager for the White Pine Power Project (WPPP), regarding the proposed 45,298 acre withdrawal of public land in Clark County and Lincoln county, Nevada and the ultimate intent to exchange this land for land in Florida. The LADWP concerns relate to electric transmission corridors within the land to be exchanged. This exchange could seriously impact the proposed WPPP transmission lines, as well as result in closure of the major north-south utility transmission corridor in eastern Nevada.

The WPPP is a proposed 1500 megawatt, coal-fueled generating to be located in eastern Nevada. The construction and operation of this $\$ 2.5$ billion facility would result in significant economic benefits to the state of Nevada. The LADWP has been working with the Bureau of Land Management (BLM) since 1980 on the routing and envirommental assessment of corridors from the proposed WPPP site in white Pine County. Nevada to southern Nevada. The preferred and alternative two-mile-wide corridors are included in the WPPP Final Environmental Impact Report (EIS) which was released on August 20, 1984. The Record of Decision, which culminated six years of intensive coordinated work with federal agencies, was signed by the BLM Nevada State Director on March 26, 1985.

A critical segment of the preferred transmission corridor. as described in the WPPP Final EIS, is located east of the Delamar Mountains. The alternative to this segment, located near the Pahranagat Wildlife Refuge, is currently constrained by wilderness study Area (WSA) boundaries. Should the WSA boundaries be modified, as requested in several letters to the BLM, the new preferred corridor would be to the west of the Delamar Mountains and parallel to existing and planned transmission lines, including a second 


\section{7}

Mr. Donald P. Hodel

$-2-$

September 18,1986

Intermountain Power Project transmission line which has been previously evaluated by the BLM. The proposed land exchange, however, would preclude the use of either WPPP corridor and would result in no path for transmission of electricity from WPPP.

The above concerns have been conveyed to the U.S. Fish and wildlife service (USFWS) by enclosed letter dated August 18. 1986. To date, USFWS has not provided any provisions for allowance tor issuance of rights-of-way for WPPP corridors within the land (HR5435 and 52758) In addition, the current proposed legislation evaluated corridors. It should an any provisions for previously suggested certain land exchanges also be noted that LADWP has also discussed in the enclosed letes, including land in this area, as department.

It is requested that public land use for projects such as WPPP with significant economic benefits (and for projects such environmental assessments, consistent with federa law, have been made) be considered with federal environmental made. In addition, any considered before any Iand exchange is include provisions to public interest.

Your attention in this matter is appreciated. If additional information is needed, please contact me

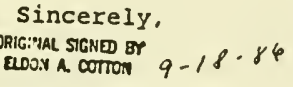

ELDON A. COTTON

Project Manager

\section{Enclosures}

\section{cc: w/Enclosures}

Mr. Robert F. Burford, BLM

Mr. William P. Horn, USFWS

Mr. Edward $F$. Spang, Director, Nevada BLM

Mr. John Lampros, Chairman, White Pine County Commission

\section{bc: w/Enclosures}

WPPP Management Committee

D. W. Waters

A. R. Cordova

E. A. Cotton

Vernon L. Pruett

E. Karapetian

E. P. Bock

Norman E. Nichols
J. P. Mieding

M.' Yamada

T. R. Irwin
R. P. Merio

Files 
Addition to March 26, 1987 veralon ol 5. 854, "Nevada-Florlda Land Exchange Authorization Act of $1987^{\prime \prime}$

Rldar 1 [insert as new subsectlons 2 (d) and 2 (e)] TRANSMISSION CORRIDOR.--The transfer of the Clark County and Lincoln County, Nevada land raferenced in subsection (a) shall be subject to the reservation to the United States of the rightof-way corridor described in the draft exchange agreement referenced In subsection (c). Thls corridor hall be designated and administered by the secrotary, who may grant rights-of-way over, upon, under, and through the corridor for systems and facilities used or useful for the construction, operation and malntenance of electric transmission lines consistent with Title $\mathrm{v}$ of the Federal Land Policy and Management Act of 1976; provided, that although activitles to construct, operate and malntain alectric transmission lines within the corrldor shall be given priority over all conflicting activities, the SECRETARY shall also do evarything in his power to facllitate and protect the activities planned and proposed for the clark county and Incoln County, Nevada land referenced in subsection (a) by AerojetGeneral corporation relating to the development, manufacture and testing of rocket motors of other aerospace and defense products, including the granting of rights-of-way to Aerojet-General corporation for roads across the corrldor connecting the eastern and western portions of the Clark County and Incoln County, Nevada land 
referenced in cubsection (a). If, after five years from the date of thie Act, other public lands within the six mile wiath weat of the clark County and IIncoln County, revada land referenced in subsection (a) are returned to multiple use, and are sultable and made avallable for the conatruction, operation and malntenance of electric transmission 11nes, no turther rights-of-way or other rights or privileges to construct, operate and maintain electric transmission I1nes within the corridor reserved in this subsection shall be granted by the secretary unless: (1) buch rights-or-way or other rights or privileges are pursuant to or in furtherance or contination of the existing rights referred to in subsection (e): (11) at the time the land becomes so avallable there is pending an application for a rightof-way in the corridor reserved in this subsection and in the opinion of the Secretary such application is being diligently pursued; or (111) such rights-of-way or other rights or privileges are in cont1nuation of a right-of-way granted prlor to the land becoming so ava1dable.

(e) PRESERVATION OF EXISTIHG RIGHTS.--The existing rights referred to in subsection (a) Include the right-of-way (Number U-42519, granted Apri1 3, 1980) to construct, operate and maintain an - lectric transmission line from the Intermountain Power Project at Delta, Utah through the Clark county and Iincoln County, Nevada land referenced in subsection (a), and the interest of the whlte Pine Power Project in the in the southern Transmission system (described and analyzed in the Final Envirommental Impact statement as the selected alternative and displayed on the map attached to the Record of 
Decilen approved on March 26, 1985), within the clark County and Incoln County, Nevada land raferenced in subsection (a). Nothing in thia Act or in the exchange agrament referenced in subsection (c) chall negate or diminish such oxisting rights in any respect; oreviced that (unless otherwlse agreed to by the owner of the clark county and Incoln County, Nevada land referenced in aubsection (a)) on and after coneumation of the exchange of lants authorized by this Act and whout further act by the holders of such exleting rights, such exlsting rights shall be altered so that: (1) all tranamission I ines and related facilitles to be located on the clark County and Lincoln County, Nevada land referenced in subsection (a) pursuant to such existing rights may only be located withlin the corridor referenced In subsection (d); and (11) the rlght to locate such transmission Ifres and ralated facillties pursuant to such existing rights on the clark County and Iincoln County, Nevada land referenced in subsection (a) outside of sald corrlcor shall be extinquished and of no further force or effect. 


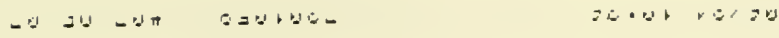

AEROJET hall have the right at 1 ta election to terminate this Agreerent in 1ts entirety without iault or liabil1ty 1:, within that time, it 1s unablo to effectuato surrander or relinquishment of such lease, license, peralt, contract or fight-of-way. 
Mod1flcation of Paragraph 15 of draft Land Exchange Agreement between Aerofet-General Corporation and the Unlted states of Amerlea dated March 1, 1987

15.

(a) The transfer of the coyote spring land under thle Agrement shall be subject to the reservation to the UNITED STATES of a right-ol-way corridor (the "Corridor") sltuated in the state of Nevada, counties of Incoln and clark, described as follows:

(1) All those portlons of sections 19, 30, 31, T.11 S., R.63 E., M.D.M.; Sections 5, 6, 8, 9, 16 , $17,20,21,28,29,32,33$, T.12 S., R.63 E., M.D.M. and sections 4, 9, 10, 15, 16, 21, 22, T.13 S., R.63 E., M.D.M., lying within that corrldor one mlle in width, the centerline of sald corrldor being one mile easterly of and parallel with the centerline of U.S. H1ghway 93. Also, all of sections $20,21,22,29,32$, and the $N 1 / 2$ of section 23, T.11 S., R.63 E., M.D.M.

(2) That portion of section 29, T.12 S., R.63 E., M.D.M., necessary for the purpose of 1ngress and egress to the corridor as required for the construction, operation, and maintenance of electric transmissicn I1nes. 
The Corrldor shall be admindstered by ths SECRETARY, who may grant rlghts-of-way over, upon, under, or through the corrldor for systems and lacilities used or useful for the construction, operation and malntenance of electrle transmission lines consistent with Tltle $V$ of FIPMA; DEoyided, that although actIvitios to construct, operate and malntain electric transmisalon ines within the corridor shall be given prlorfty over all conflicting activit1es, the SECRETARY shall also do everything in his power to lacilitate and protect the activities planned and proposed for the coyote spring Land by AEROJET relating to the development, manufacture and testing of rocket motors or other aerospace and defense products, including the granting of Ifghts-of-way to AEROJET for roads across the corridor connecting the eastern and western portions of the coyote spring Land.

(b) In consideration of the corridor reserved by the SECRETARY, and except with respect to the rights referred to in subsection 2 (e) of the Act which are altered by the Act, the SECRETARY agrees not to grant any rights-of-way over, upon, under, or through the corrldor to any party who currently holds, directly or indirectly any lease, l1cense, permit, contract or right-of-way for electric transmission line facilities and systems on the coyote spring land unless such party, as a condition to using the corridor, surrenders and relinquighes all of 1ta right, title and Interest in and to such lease, license, permit, contract or right-of-way. In add1tion, as a condition subsequent to execution hereof but before settlement, 
Senator Hecht. Thank you very much.

I am just going to ask Mr. Horn a couple of questions for the record. I am going to submit some other questions to all of you in writing.

A couple of concerns have been brought up.

Mr. Horn, it has been alleged that the appraisal of the public lands in Nevada identified for exchange is under the fair market value of these lands and therefore violates the requirement for an equal value exchange.

Please describe for the Committee the appraisal process that was used to determine the value of both the Florida and the Nevada properties.

Mr. Honn. I would just outline that I have the Chief of the Realty Section of the Fish and Wildlife Service present, and Mr. Spang, who is the BLM State Director could get into this in detail for you, if you wish.

But, suffice it to say, all the appraisals were conducted pursuant to established procedures by duly authorized and competent professionals. All the appraisals have been approved by, respectively, the Bureau of Land Management and the U.S. Fish and Wildlife Service.

So I think it is safe to say, as I indicated in my statement, that we are dealing here with approved, professionally executed appraisals. Either gentleman could give you some detail, either now or in writing, as to all of the procedures and steps employed. So I think it is safe to say that you can rely on these as accurate appraisals.

Senator Hechт. Since this is a concern, would you please have them submit those procedures and the appraisals to the Committee in writing?

Mr. Horn. Yes, sir.

[The information was received by the subcommittee and has been retained in the files.]

Senator Hecht. Another question has been brought up.

I assume the department and your attorneys have examined the questions of whether an Environmental Impact Statement must be prepared for Congressional authorized interstate land exchanges of the sort we are dealing with here.

Assuming that this question has been examined, what is the department's position on this?

Mr. HorN. Mr. Chairman, it is established law that Congress is exempt from the provisions of the National Environmental Policy Act. The requirements for EIS's apply only to administrative agencies undertaking executive action.

But we wanted to make sure that in providing our drafting assistance to Congress, that, basically, a thorough review of environmental issues had been done. So we prepared the Resource Ascertainment Report, which is the functional equivalent of an Environmental Assessment, which is one of the key steps in NEPA compliance. That, coupled with the extensive EIS work done by the Air Force under the MX proposal I think, provides the Congress with a very thorough record and factual bases for judging the merits of this proposal.

If you put it all together, you basically have all of the information that would be provided through an EIS. 
Senator Hecht. Thank you.

Is the Coyote Springs Valley in Nevada a designated "critical habitat" for the desert tortoise?

Mr. HoRn. No.

The desert tortoise is only one of 3,900 candidate species for prospective or potential listing under the Endangered Species Act. Because it is a candidate species, we have some level of concern about it. That is one of the reasons that we engaged in some of the endangered species review and the environmental analysis.

We are persuaded that the mitigation and conservation stipulations built into the draft exchange agreement with Aerojet, including the set-aside of an 18,000 acre desert tortoise preserve, more than adequately deal with protecting this species in this particular area.

Senator Hecht. Thank you.

Please describe for the Committee the stipulations which the department has entered into with Aerojet with respect to the protection of groundwater resources, and specifically for the protection of the endangered fish, which I understand are located outside the exchange area.

Mr. HorN. As I indicated, the four endangered species of fish inhabit springs that are 45 miles and 12 miles away from the Aerojet site.

All of the water extraction that might occur on this property is going to be pursuant to State law, and we-again, this is one I would just as soon provide for the record because it is quite complicated-have provided a system and a series of provisions to ensure that we are duly notified; that there will be extensive monitoring on the site; to ensure that any groundwater extraction, in accordance with State permits, does not adversely affect these two springs, which are habitat for these fish.

[Subsequent to the hearing the Interior Department submitted the following:]

PROVISIONS OF THE DRAFT AGREEMENT RELATING TO WATER EXTRACTION

Upon the issuance of a written opinion by FWS to Aerojet that the withdrawal of groundwater from beneath the Nevada Land (as defined in the body of the Agreement) has caused the depletion of water to any surface water habitat of a federallylisted endangered or threatened species and that such depletion is having an immediate adverse effect on such species, Aerojet and the FWS shall jointly seek a determination from the Nevada State Engineer or some other mutually agreeable independent third party (such as U.S. Geological Survey), as to the cause of the depletion. Should it be determined by the State Engineer, or other mutually agreed-upon third party, that the withdrawal of groundwater from beneath the Nevada Land, by Aerojet, is the sole cause of the depletion of water to a surface water habitat of any federally-listed endangered or threatened species, then Aerojet and FWS shall jointly petition the State Engineer to reduce the total water allocation in the affected area, in accordance with State law, until the adverse effect has been eliminated, at which level the water allocations shall remain until otherwise provided by the State Engineer.

Senator Неснт. Will the stipulations agreed to by Aerojet and the Department of the Interior continue in effect if at some later date Aerojet should attempt to dispose of Nevada property?

Mr. Horn. Yes. 
They will run with the land and be built into the conveyance document, so that if Aerojet ever sells to anybody else, the subsequent purchaser is bound by the same terms and conditions.

Senator Hecht. Does the Department of the Interior have a firm commitment from the State of Florida to purchase the Dade County property that will be acquired from Aerojet under this exchange?

Mr. Horn. Yes.

We have a formal written offer from the South Florida Water Management District that we have provided to the Committee, and it is part of the record.

Senator Hecht. As I remember, the bill required that the funds obtained from the State of Florida must be held to acquire environmentally significant lands of interest to the Department of the Interior.

Has the department identified the property that will be purchased to augment the National Wildlife Refuge System in Florida?

Mr. HorN. Yes.

As indicated, we would intend to use this money to buy in-holdings within the Lower Suwannee Wildlife Refuge, which is primarily focused on the Crystal River population of endangered manatee, and in-holdings within the Key Deer Wildlife Refuge, located twothirds of the way down the Florida Keys, which is a critical habitat for the endangered Key Deer.

Senator Hеснт. I have some questions which I am going to submit to you, and a few others, which I do not want to take time with now. But I would appreciate written statements on each of these because perhaps when Senator Reid has his hearings in southern Nevada, they would be quite useful. And they should be for the record more than just off-the-cuff answers.

But I appreciate your candor.

Mr. HoRn. Thank you.

Senator HECHT. I thank all of you very much.

Go back to work, Bob.

Mr. BurFord. Will do.

Senator Hecht. I see where David Hagan is a Counsel for the White Pine Power Project in Reno, Nevada, and Mike Yamada a Power Engineer.

Do they have anything they want to submit for the record or say anything while they are here?

Mr. HAGAN. Erik Bok has spoken for us. Thank you very much.

Senator HeCHT. Thank you very much.

Mr. Hagan. Sir, Mr. Bok has already submitted for us. We have submitted comments also for the record.

Senator HECHT. So, everything is taken care of, and you can only bill your clients for half a day, then. [General laughter.]

Okay, next is Panel Number One: Betty Burge, Dave Hornbeck, Jean Perry-Jones, Charles Watson, Charles Callison, and Gail Harris.

Here is how we are going to handle all of you. We are going to give you five minutes. But if you need it, you may have a little more time to summarize. When you see the red light, I am not going to cut you off. But please, then start to summarize.

Okay, first is Betty Burge. 

VEGAS, NV

Ms. Burge. The Desert Tortoise Council is a professional organization, composed mainly of wildlife biologists and some interested laymen.

In 1984, Council biologists prepared an 850 page report for the Fish and Wildlife Service on the status of the desert tortoise. We documented declining tortoise numbers and increasing cumulative impacts to tortoise habitat.

In 1985, the Fish and Wildlife Service determined that listing the tortoise was warranted. However, this has yet to be implemented.

On-going investigations show that declines continue. The tortoise is in trouble.

As a field biologist working with the tortoise for 14 years, I have helped with these investigations.

In Nevada, the tortoise is confined to the southern tip, near Las Vegas. Within this distribution, the Council delineated six areas that may continue to support viable populations in the future if the land is managed properly.

We call these areas "crucial desert tortoise habitats."

Coyote Springs Valley is located within one of the least impacted of the six habitats. As yet, no land has been set aside in Nevada where the tortoise would be protected into the future. Meanwhile, degradation and loss of habitat continue. This is particularly true at the rapidly expanding boundary of Las Vegas. As degradation and loss occur, the importance of Coyote Springs Valley increases.

Aerojet would fragment this crucial habitat by taking the core of it. This would result in immediate loss of some land and tortoises, adding to the cumulative impact to crucial habitat by a substantial increment, and hastening the need for listing. And there is no guarantee that after 20 years, the entire 50 square miles would not be sold and developed. The advisory board could concur.

Benefits of prior mitigation would be cancelled. The mitigation proposed by Aerojet is inadequate. Their proposed action regarding fencing roads and relocating tortoises are biologically unsound.

The environmental documents associated with S. 854 are flawed.

I refer you to the numerous examples described in our position statement.

We are led to believe that the project will benefit the tortoise. Actually, the net effects will be negative.

If Aerojet were to utilize tortoise habitat, specified mitigation and compensation measures proposed by tortoise experts should be incorporated into the agreement. As it is now and would be with an advisory board, proposals for sound tortoise management would be subject to arbitrary rejection by Aerojet.

Economic diversity and additional employment opportunities would be possible if Aerojet were to locate elsewhere in Nevada. Aerojet should explore alternative locations in Nevada, and the Department of Interior should evaluate all proposed sites, including Coyote Springs Valley, prepare formal Environmental Impact Statements, and include the public commenting process.

This project deserves more than the cursory evaluation that it has received so far from Federal and State agencies. 
That is all I have to say.

[The statement follows:] 


\title{
THE HTAM \\ DESERT TORTOISE COUNCIL
}

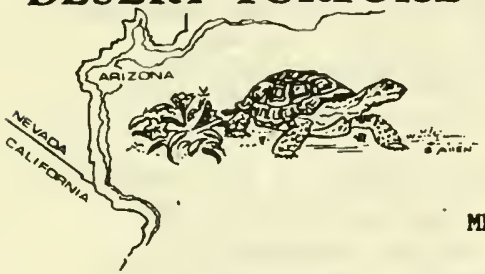

5319 Cerritos Avenue

Long Beach, California 90805

June 22, 1987

\section{MEMORANDUM}

TO: Senate Subcomittee on Public Lands

FROM: Glenn R. Stewart, Senior Co-Chairman

SUBJECT: S.854, "Nevada-Florida Land Exchange Authorization Act of 1987"

I have enclosed two documents and request that they be entered for the record as testimony presented before the Senate Subcomittee on Public Lands, June 30,1987 .

Document (1): Position Statement of the Desert Tortoise Counc1l S.854, "Nevada-Florida Land Exchange Authorization Act of 1987"

\author{
Document (2): Letter from the Desert Tortoise Council to Ralph E. \\ Clark, Executive Vice-President and General Manager, \\ Aerojet Nevada
}

The following summarizes some of the items in the position statement.

The Desert Tortolse Council is opposed to S.854. If S.854 is passed, 81 square miles of public land. that has not been identified for disposal. would be removed from public domain and offered to Aerojet Nevada in exchange for only 7 square miles of private land located in Florida and owned by Aerojet-General Corporation.

The construction and use of the facility proposed by Aerojet Nevada, in Coyote Spring Valley, would negatively impact 67 contiguous square miles of relatively undisturbed desert tortolse habitat. The proposed exchange area is located at the core of habitat identified as crucial to the long-term survival of the tortoise in Nevada.

The U.S.F1sh and Wildife Service determined In 1985 that 11 sting of the tortolse is warranted. No listing package has been prepared but this is because there are too many specles awaiting listing for the linited staff to do the work.

The Section 7 Consultation by the Flsh and Wildlife Service on the subject of the Nevada land exchange concluded that the effects upon 11 sted and candidate species would not be restricted to the direct and imnediate impacts of Aerojet. The eventual sale of the land would further degrade desert tortolse habitat and have a major negative impact upon one of only six known areas in Nevada where tortolse populations may be viable. The Section 7 Consultation has been downplayed by those who belleve that the land exchange would benefit the tortoise or that all impacts would be 
mitigable. If $S .854$ is passed the result would further feopardize a species that has already been found to need listing.

Environmental documents associated with S. 854 are flawed. The preparers 1) have falled to utilize the most recent data avallable, 2) have misinterpreted data, and 3 ) have disregarded information provided by nationally recognized tortolse experts. As a result, the evaluations presented in these environmental documents are misleading.

Mitigation measures proposed by Aerojet are not adequate; in fact, some of the projected impacts cannot be mitigated. Fac1lity construction would result in immediate, permanent $108 s$ of part of the habltat. Several hundred tortolses would be displaced, their survival questionable because relocation has not been proven effective. Predation, collecting, and the incidence of road $\mathrm{kills}$ would increase. There is no guarantee to protect the undeveloped habitat beyond 20 years, at which time all the land could be sold and developed. The long-term survival of the tortoise in the area would be placed at high risk.

Aerojet should seek alternative sites in Nevada or elsewhere on which to locate facilities. The evaluations of those sites should be presented in carefully prepared environmental documents and made avallable through a public commenting process.

encl : 2

cc: Nevada Department of Wildlife

Senator Chic Hecht

Senator Harry Re1d

Representative Barbara Vucanovich

Representative James Bilbray

Senator J. Bennett Johnston, Chr. Senate Comittee on Energy and Natural Resources

Representative Morris Udall,Chr. House Committee on Interior and Insular Affairs

Senator Dale Bumpers, Chr. Senate Subcommittee on Public Lands

U.S. Fish and Wildilfe Service

Nevada Legislature's Committee on Public Lands

Nevada W1ldilfe Federation

Defenders of Wildilfe

other Interested Parties 


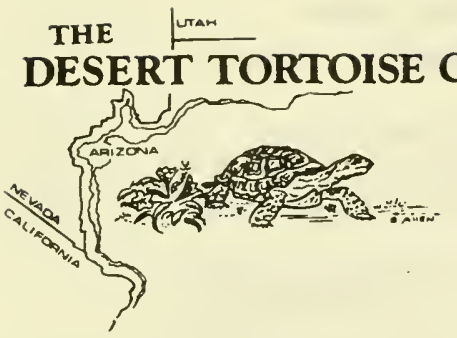

\author{
5319 Cerritos Avenue \\ Long Beach, California 90805
}

June 21,1987

Mr. Ralph E. Clark, Executive Vice-President and General Manager

AEROJET NEVADA

One Aerojet Way

North Las Vegas, Nevada 89030

Dear Mr. Clark:

During the last month, several Nevadans have contacted us with disturbing information. They have told us that certain individuals, apparently acting on behalf of AEROJET NEVADA, have mlsrepresented the Desert Tortoise Counc1l's position on Aerojet's proposed land exchange for Coyote Spring Valley. The Desert Tortolse Counc1l is opposed to the land exchange and to Aerolet's accuisition of land in Corote Spring Valley. Our position and rationale are enclosed.

We request that you and representatives of AEROJET NEVADA cease and desist in making any written or oral statements wh1ch $1 \mathrm{mply}$ that the Desert Tortolse Counc1l approves of the proposed land exchange. Furthermore, we request that you contact persons who have been given this erroneous information by your staff or representatives and inform them of the error.

We appreclate your early attention to this matter.

Sincerely yours,

Is/ Glenn R. Stwast

Glenn R. Stewart

Sentor Co-Cha1rman

cc: Willam Molin1, Director, Nevada Department of W1ldlife

Senator Chic Hecht

Senator Harry Reld

Representat1ve Barbara Vucanovich

Representative James Bllbray

Senator J. Bennett Johnston, Chr. Senate Committee on Energy and Natural Resources

Representative Morris Udal1, Chr. House Committee on Interlor and Insular Affairs

other Interested Part1es 
POSITION STATEMENT OF THE DESERT TORTOISE COUNCIL

S. 854, "Nevada-Florida Land Exchange Authorization Act of 1987"

prepared by the Desert Tortoise Council, June 7, 1987

I. S. 854 IS SPECIAL LEGISLATION THAT WILL BENEFIT AEROJET AND A VERY SMALL GROUP OF PEOPLE IN NEVADA

On March 26, Senator Chic Hecht stated that S. 854 allows everyone to win--the National Wildlife Refuge System, the State of Florida, and the State of Nevada (Congressional Record Vol. 133, No. 49). We do not believe this. Senator Hecht should have mentioned that Aerojet General and Aerojet Nevada will be the real winners if this legislation is passed. Taken in a much broader perspective, the people of the United States will lose a large block of public land and, in turn, will gain a very small piece of habitat for the National wildlife Refuge system in Florida. Another issue here is the appraised value of the Nevada public land. We believe that the value of public land has been grossly understated.

II. THE PROPONENTS OF THE BILL SHOULD FOLLOW PROCEDURES PREVIOUSLY ESTABLISHED BY THE FEDERAL LAND PLANNING AND MANAGEMENT ACT AND NATIONAL ENVIRONMENTAL POLICY ACT

Congress established a number of laws and acts for the protection and wise management of public lands. The Nevada lands proposed for exchange are public lands under the jurisdiction of the Department of Interior, Bureau of Land Management (BL.M), and should be subject to the protection of the existing federal land planning laws and policies. $S$. 854 bypasses these safeguards.

We believe that the BLM should complete its management framework or coordinated resource management plans for these areas prior to any discussions of land trades. If, during the planning process, the Bureau of Land Management identifies lands appropriate for disposal, then Aerojet could attempt to acquire these either at a fair market value or through a land exchange supported by congressional legislation. An Environmental Impact Statement should be prepared by experts.

If Congress passes S. 854, then the door is opened for similar legislation which would allow transfer of more public lands to special interest groups.

\section{AEROJET GENERAL DOES NOT HAVE A GOOD ENVIRONMENTAL TRACK RECORD}

In 1985, Aerojet General was cited by the Environmental Protection Agency for injecting hazardous wastes into a source of underground drinking water in the Sacramento area. The Environmental Protection Agency denied Aeroject permits for continued operation of injection wells. In 1986, Aerojet General Corporation actively opposed the California voters' initiative to control toxic wastes by contributing 
$\$ 10,000$ to "Californians Against the Toxics Initiative." The initiative to control toxic wastes was passed overwhelmingly by California voters in the November 1986 election, in spite of efforts by corporations such as Aerojet General.

We do not believe the subject of toxic waste management and disposal has been adequately covered in the legislative and environmental documents.

IV. FEDERAL AND STATE AGENCIES DID NOT USE THE ADVICE OF THEIR OWN BIOLOGISTS AND DESERT TORTOISE EXPERTS ON THE AEROJET PROPOSAL

The Fish and Wildlife Service made strong statements about the negative impacts of Aerojet's proposal on desert tortoises in a Formal Section 7 Consultation for Nevada Land Disposal (see Case Number 1-5-87-FW-9; Memorandum from the Regional Director of Region 1 to the Asst. Regional Director of Region 1, dated Dec. 11, 1986). The Regional Director states:

The effects of this proposal to listed and candidate species are not restricted to those anticipated by Aerojet and their activities. The eventual sale of this land opens the way for indirect effects that will further degrade lands, and hence, desert tortoise habitat... It is believed that these future impacts will be more detrimental to local listed and candidate species than the activities of Aerojet. This would result in approximately 17,000 acres of crucial, moderate-density desert tortoise habitat being adversely affected. This would represent a major negative impact to one of the only six known areas in Nevada where tortoise populations are believed sufficient to maintain viable populations. Past release of Federal lands in Nevada has caused problems that have resulted in the listing of 11 plants and animals as threatened or endangered... [pg. 13]

The Fish and Wildlife Service downplayed and understated these impacts to the desert tortoise in the Resource Ascertainment Report, Drafting Service for Members of the Nevada and Florida Congressional Delegations, Nevada-Florida Land Exchange. The above statements were not included in the Resource Ascertainment Report.

In addition, senior level management officials in appointed positions in the Nevada Department of Wildlife ignored materials presented by staff members on the degree and nature of impacts of the Aerojet project on the desert tortoise and other species.

V. THE DESERT TORTOISE WILL LOSE HABITAT ESSENTIAL TO ITS CONTINUED EXISTENCE IN NEVADA, IF S. 854 IS PASSED

The proposed legislation contains "stipulations" which are supposed to benefit the tortoise and its habitat (Exhibit F). We do not believe that these stipulations are adequate even to mitigate impacts, much less to result in net benefits to the tortoise. In fact, they are mere window dressing. We have outlined major problem areas below. 
(1) The proposal does not take into account the recent information on the genetics of desert tortoise populations in the United States and Mexico. The tortoise population in Coyote Spring Valley, Arrow Canyon, Las Vegas Valley, and Ivanpah Valley (extreme eastern California and west-central Nevada) is a genetic unit different from all other populations. No part of this population, which occurs primarily on public domain lands, is protected. Tortoise populations in this genetic unit are rapidly declining in northern Ivanpah and Las Vegas valleys and may soon reach the point where they are no longer viable.

(2) The Federal government loses access to important tortoise habitat in Coyote Spring Valley. Government officials would be allowed to enter no more than once per month and then only during regular business hours. The Federal government would lose the ability to monitor the status and condition of these important tortoise populations.

(3) The proposal to relocate tortoises (Exhibit F, pg. 2, item 5) is inadequate and inhumane. According to Ralph Clark, General Manager of Aerojet Nevada, Aerojet has no intention of doing anything other than collecting the tortoises and moving them outside of the areas to be developed for static testing of rockets, facilities, etc. (Remarks made at the 1987 Desert Tortoise Council Symposium, March 1987).

No studies will be conducted to determine if the relocated tortoises survive. (Mr. Clark said that he personally did not think such an effort was necessary). No constraints have been placed on Aerojet as to the time of year for construction, appropriate seasons and methods for relocation of tortoises, or the type of fence to be placed around the developed facilities.

Tortoises tend to return to their home sites and will injure themselves on the fence, if the fence is not properly designed. Furthermore, it is very likely that the release area is already at or near carrying capacity. The relocated tortoises will be competing with long-term residents for food and shelter. Numerous aggressive encounters are likely to occur and the survivorship is likely to be poor.

The results of tortoise relocation efforts were addressed at the 1987 Desert Tortoise Council Symposium, where national and international experts on relocation of turtles and tortoises gathered to discuss the pros and cons of relocation in a special session. The experts concluded that relocation efforts have not been particularly successful to date. Many problems have been documented. Tortoises have high fidelity to their homesites. They use the same areas year after year, and many do not thrive when moved. The experts concluded that relocation should be undertaken only as a last resort, 
only with intensive preparation, long-term monitoring with radio telemetry, and with expert advice and assistance.

(4) The proposal (Exhibit F, pg. 2, item 5) to fence portions of roads through high density tortoise habitat is inadequate and unacceptable. Preparers of the Aerojet Environmental Report and personnel at Aerojet do not have an adequate understanding of tortoise population management, movements, and behavior. The impacts of paved roads on tortoise populations are well documented. In 1977 and 1978, the Bureau of Land Management in California conducted research on effects of roads on tortoises. They reported that tortoise populations decline significantly to distances of 0.5 to 1 mile on either side of a well-used road. Since the old highway in Coyote Spring Valley has not been used for many years, tortoises have gradually reoccupied the area on and adjacent to the old road. Many tortoises would be at risk with reconstruction and use of the highway.

If only parts of the old highway and roads through tortoise crucial habitat are fenced, the tortoises from high density habitat will be forced to move along the fence to areas with no fencing in moderate to low density habitats. All tortoises crossing roads at the fencing gaps will be at risk.

All roads used by Aerojet in Desert Tortoise Crucial Habitat in Coyote Spring Valley and Arrow Canyon should be fenced with tortoise-proof fencing and standard tortoise underpasses should be constructed underneath the roads. The Desert Tortoise Crucial Habitat is shown in Plate 8-7 of the report, "The Status of the Desert Tortoise (Gopherus agassizii) in the United States," dated 1984 and edited by $K$. H. Berry (report from Desert Tortoise Council to U. S. Fish and Wildlife Service, Sacramento, California). The California Department of Transportation supported a pilot study on the subject and identified effective types of culverts and fencing. Their results should be used to design the fence and culverts.

(5) The proposal (Exhibit F, pg, 2, items 3 and 4) to place a reasonable number of signs (not to exceed 20) along the highway to warn motorists to drive carefully to protect tortoises is a totally inadequate and unwise mitigation. Motorists have difficultly seeing adult tortoises in time to avoid hitting them, and are even less likely to see the juveniles. The signs will call attention to the presence of tortoises in the area and will stimulate illegal collecting.

(6) The proposal (Exhibit F, pp. 3-4, item 9) to set aside a reserved area of 17,885 acres for 20 years to encourage study and observation of the tortoises does virtually nothing to ensure the long-term protection and conservation of the 
desert tortoise population in Coyote Spring Valley. Although superficially appealing, the proposal is worthless in a longterm sense. After 20 years, development could take place.

The proposed reserve does not meet essential specifications outlined by experts in reserves, parks, or refuges (see studies by J. Diamond, M. Soule, B. Wilcox, and others). The proposed reserve is fragmented and too small to meet the long-term biological needs of desert tortoises.

(7) The proposed buffer zone of 11,420 acres has no tortoise management plan. These lands can be sold after 20 years. If sale or development of these land occurs, tortoise habitat would be further fragmented and tortoise populations in the reserved area would be jeopardized.

(8) The proposal to have a seven-member Board (Exhibit F, pg. 4) oversee the "reserved acreage" is unacceptable to us. Most members of the board will be political appointees. None will have tortoise expertise. It is our collective experience--and many of us are government employees--that such Boards place far more weight on benefits of economic development than on the well-being of threatened and endangered species.

Aerojet has had the opportunity to use our collective expertise on many occasions in 1986 and 1987. As of June, 1987. Aerojet has shown no willingness to utilize our experience and information. Instead, Aerojet has chosen to seek advice of political appointees in senior management positions. Aerojet has misinterpreted data on distribution and density of the tortoise, apparently for self-serving purposes.

VI. ENVIRONMENTAL DOCUMENTS ASSOCIATED WITH S. 854 ARE SERIOUSLY FLAWED

Several documents associated with the S. 854 proposal are seriously flawed. They contain false statements, errors of fact, and misleading information. In general, they indicate that tortoise populations and habitat will not suffer unmitigable impacts or irreparable harm. These reports indicate, falsely, that passage of S. 854 will not jeopardize the continued existence of important tortoise habitats in Nevada.

Examples include:

Aerojet-General Corporation, Florida-Nevada Land Exchange. Environmental Report for Coyote Spring Valley. Prepared by Resource Concepts, Inc., Carson city, Nevada. February 1987.

(1) pg. vii, pp. 125 and 126. The preparers state that 81 acres would be permanently lost, 224 acres would be disturbed, and 2760 acres would be enclosed by fencing. In fact, 2760 acres would be lost. This is habitat for 160 to 325 
tortoises. The fencing also will partially fragment habitat of several hundred additional tortoises, who have parts of home ranges inside the fenced areas.

(2) pp. vii and viii, pg. 127. The preparers state that in addition to the reserve area, the powerline corridor of 10,555 acres would function as additional protection, with negative impacts limited to powerline construction and maintenance. However, the transmission line towers are used as perches by the raven, a highly effective predator on juvenile tortoises. In practice, with each new powerline, perch sites will increase and aditional tortoise habitat will be lost.

The proposed reserve, buffer zone, and corridor combined do not meet the minimum standards for preserves for species such as the desert tortoise. The minimum standards have been set by scientists working together nationally and internationally to protect rare, threatened, and endangered species.

(3) pp. vii and viii. The preparers fail to mention in this section that the Conservation Reserve is guaranteed for only 20 years! After that time, it could be developed.

(4) pp. 97, 98; Fig. 4.11. The preparers call densities of 0 to 45 tortoises per square mile low density. We disagree. We use the term low density to refer to densities of 0 to 10 or 0 to 20 tortoises per square mile. We use these designations in all four states where desert tortoises occur. The preparers have misinterpreted data and have redefined "low densities" for their own purposes.

(5) pp. 97, 98 and Figs. 4.10 and 4.11. These pages contain misleading information about tortoise distribution and abundance. We have repeatedly advised Mr. Clark, General Manager of Aerojet Nevada, of problems with these figures. We have provided him with a map of tortoise densities delineated by desert tortoise experts. See enclosed map, Plate 8-7.

The preparers address the negative impacts to areas with moderate and high tortoise densities only. This is a limited view of what is critical. Actually, any area large enough to sustain a viable subpopulation (such as the proposed Aerojet exchange) naturally includes small areas of low density $(0-20$ tortoises per square mile). It is essential to consider impacts to the total area.

The preparers state that the exchange boundary area would encompass only 14\% of the tortoise habitat in Arrow Canyon/ Coyote Springs valley. This is a misleading statement. The proposed Aerojet Land Exchange lies within the core of Arrow Canyon/Coyote spring Valley tortoise habitat. 
The preparers fail to take into account the fragmenting effects of the project. This must be addressed.

(6) pg. 124. The preparers make the statements that "[305] acres of tortoise habitat would be degraded or permanently removed. Tortoise movements would be restricted within 2,760 acres." This statement is incorrect. At least 2760 acres would be lost to tortoises. Tortoises would be removed from and fenced out of 2760 acres.

pg. 124. The preparers state: "The degradation, permanent loss, and fencing of tortoise habitat would be situated outside of areas where moderate to high density tortoises habitat have been indicated by previous population sampling efforts." This statement is patently false. Most areas contain moderate densities of 45 to 90 tortoises per square mile; some sites have high densities of up to 140 tortoises per square mile.

Resource Ascertainment Report, Drafting Service for Members of the Nevada and Florida Congressional Delegations, Nevada-Florida Land

Exchange. Undated. Although this report probably has been superseded by other, more recent documents, it still contains considerable misinformation.

pg. 13. The statement is made that "Most of the valley is poor wildlife habitat, except for desert-adapted species such as the desert tortoise." This statement gives an erroneous impression about deserts and desert-adapted species. In fact, the valley offers outstanding habitat for over 20 species of reptiles, 30 breeding birds, and about 30 species of manmals. The preparers appear to be comparing desert-adapted to non-desert adapted species. The preparers appear to be placing a value judgment on desert habitats and species that are adapted to desert habitats, calling them poor.

pp. 13, 14. The statement is made that the desert tortoise is a candidate species for federal listing. This is true in part. In fact, in December of 1985, U. S. Fish and Wildlife Service determined that desert tortoise populations were declining throughout the geographic range in the United States and that federal listing is warranted (Federal Register 50 [234]:4986849870 ). The listing package has not been prepared, because the (1) the Fish and Wildifife Service is inadequately staffed, and (2) there is a long list of species waiting to be listed.

In the Mojave Desert of California, Nevada, and Utah, recent data indicate that tortoise populations are suffering continued reductions, with some populations close to extinction.

pp. 14, 15. The statement is made that "The major threats to the tortoise are from human ...collecting and vehicular collisions... we disagree. The preparers should thoroughly review the 1984 
report on the status of the tortoise in Nevada before making such a statement. Habitat deterioration, loss, and fragmentation are major issues. Deterioration and losses come from many sources, including off-road vehicle use, energy development, grazing, and urban development. Populations are declining from the above uses. collecting, vandalism, and incidental vehicle kills are only a part of a much larger issue.

pp. 15, 16. The preparers of this report imply that considerable human use already occurs in Coyote Springs Valley. This is true in part. However, the level is considerably less than in most other important tortoise habitats in Nevada. This is reason to consider this land for future withdrawal as a federal Natural Area or Area of Critical Environmental Concern.

pp. 21. The preparers state: "However there should be no unmitigable adverse impacts on the environment." This statement is erroneous. In fact, Aerojet plans many actions that are not mitigable, including:

(1) the construction of facilities and new roads that will result in:

(a) loss of about five square miles of tortoise habitat,

(b) fragmented habitat,

(c) fences and facilities which will provide perches and which will enhance predation

(2) the relocation of 160 to 325 tortoises, many of which will not survive

(3) the reconstruction and use of approximately 15 miles of old highway, which will increase tortoise losses from collecting by construction workers and employees, families, and friends (collecting is almost impossible to stop)

(4) the incomplete fencing and traffic will result in deaths of tortoises on roads and will deplete tortoise populations to distances of 0.5 to 1 mile on either side of roads

(5) the incomplete fencing and traffic will result in roadkills of many species of animals, which will attract scavenging ravens

(6) ravens, attracted by roadkills and perches, will increase predation on live juvenile tortoises throughout the area

pg. 23. The preparers state: "Overall, the effect on the tortoise should be negligible or beneficial." We disagree, for the reasons 
stated above, as well as others described below. The net effects will be negative. The preparers should have used information provided by the Fish and Wildlife Service in the Formal Section 7 Consultation for Land Disposal (see III, above).

(1) Human use in the general region will increase with the employment of 600 people.

(2) Fragmentation of habitat will increase.

(3) If the area or parts of the area are developed after 20 years, any benefits from prior mitigations will be cancelled.

\section{RECOMMENDATIONS}

This project deserves more than the cursory evaluation it has received so far from state and federal agencies. We strongly oppose $\mathrm{S}$. 854 as it is written, and more specifically, we oppose the location and the incomplete and flawed environmental evaluation. We recommend:

(1) Aerojet should seek out and fully evaluate alternate sites for the proposed facilities.

(a) Vast tracks of land are under the domain of the military. Some parts of these lands receive little, if any use, and would be suitable for the Aerojet facility.

(b) Tikaboo Valley. Part of this valley is under the jurisdiction of the Air Force, and serves as a buffer zone for the east side of Nellis Air Force Base.

(c) Dry Lake Valley, southeast of Caliente.

Such sites could be fully evaluated in a formal Environmental Impact statement, which would include a public commenting process.

(2) The U. S. Fish and Wildlife Service and conservation groups should seek alternative sources of funds for acquisition of important lands in the National Wildlife Refuges in Florida, e.g., through the Land and Water Conservation Fund or The Nature Conservancy.

VIII. IF AEROJET IS TO UTILIZE THE COYOTE SPRING VALLEY, THE FOLLOWING ARE AMONG THE TORTOISE MITIGATIONS AND COMPENSATION MEASURES THAT SHOULD BECOME PART OF THE AGREEMENT

Stipulations, mitigations, and compensation measures must be specified in detail and in writing.

(1) The 17,885 reserved area should be protected by Congressional mandate into perpetuity, not just for 20 years. 
(2) The 11,420 acres in the buffer zone should also be held for the the protection and conservation of desert tortoises and their habitat, as well as other animals occurring naturally in this ecosystem.

(3) A management plan for the desert tortoise should be developed for the combined reserved area, buffer zone, and corridor.

(4) Aerojet General should provide compensation to a federal or state wildlife agency for the total area of habitat lost to desert tortoises. This compensation could be in the form of acquisition of important tortoise habitat occurring on private lands in Nevada or a similar measure.

(5) The 160 to 325 tortoises to be relocated from the proposed developed areas should be part of a formal relocation project, undertaken by qualified desert tortoise scientists. These tortoises must be treated humanely. A substantial number of the tortoises should be monitored on a long-term basis using radio telemeters.

(6) The tortoise population in the reserved area should be monitored at three- to four-year intervals using methods similar or identical to the 60-day census, a method used in Nevada and elsewhere in the geographic range.

(7) All roads used by Aerojet employees in the Arrow Canyon/Coyote Spring Valley desert tortoise crucial habitat should be fenced and culverts should be installed at appropriate intervals.

(8) Aerojet should not advertise the presence of tortoises to the general public with road signs. The tortoises will be less likely to be collected, if Aerojet does not draw attention to the population.

(9) Measures should be taken to prevent increases in raven populations and to minimize raven predation on juvenile desert tortoises.

(10) Aerojet should include a nationally recognized desert tortoise expert on the Board to oversee the reserved acreage, corridor, and buffer zone. 


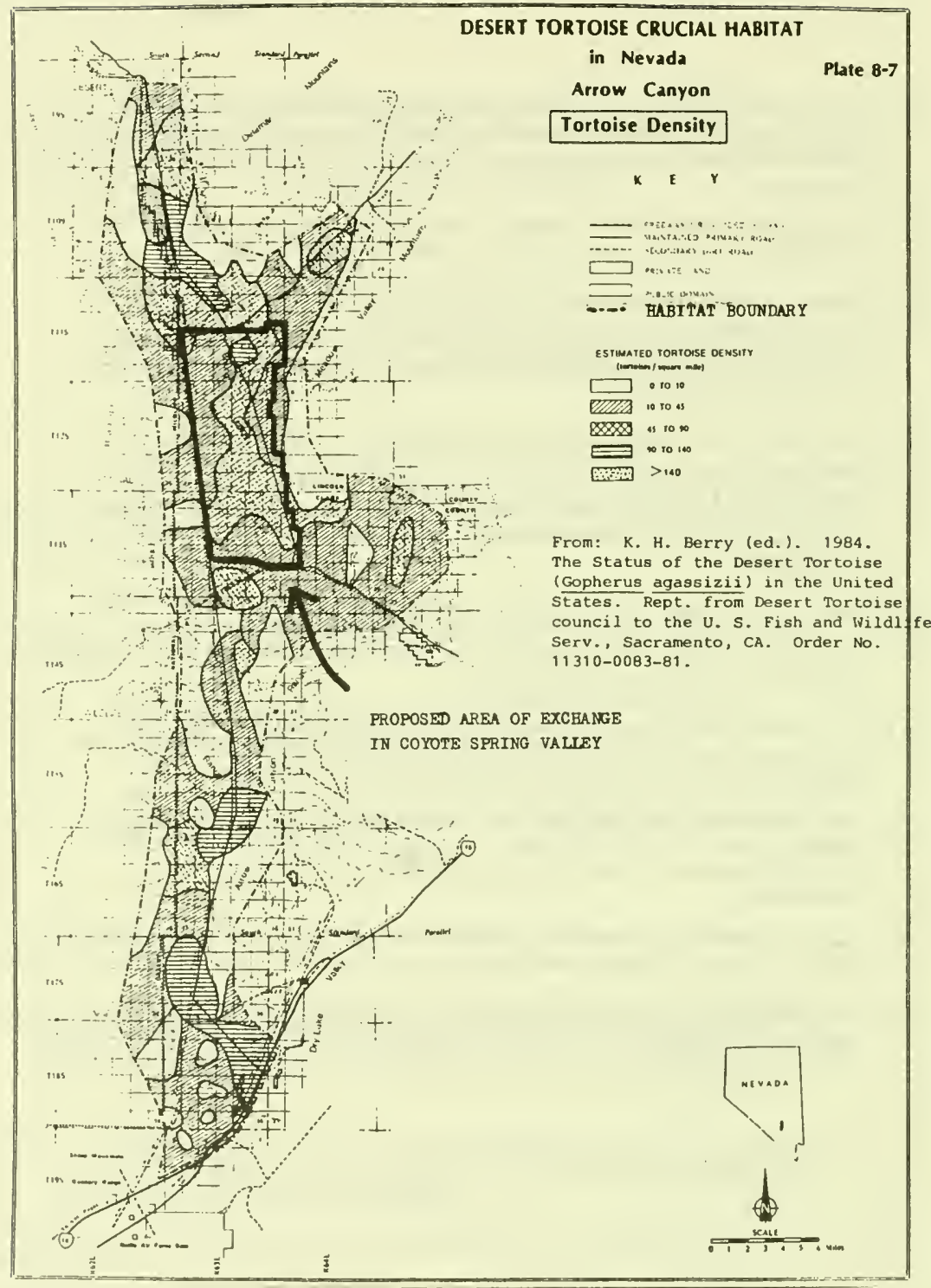


Senator Hecht. Thank you very much.

Dave Hornbeck, please.

\section{STATEMENT OF DAVID A. HORNBECK, TOIYABE CHAPTER OF THE SIERRA CLUB, RENO, NV}

Mr. HoRnBeck. Thank you, Mr. Chairman, Senator Hecht, and also any other Members of the Subcommittee.

I thank you for this opportunity to speak on behalf of the Sierra Club in expressing our views in regard to S. 854 .

My name is Dave Hornbeck. I am a native Nevadan and an attorney from Reno. However, I speak today as a member of the Sierra Club and also a member of the Executive Committee of the Toiyabe Chapter, which includes all of Nevada and some 2,200 members in Nevada and eastern California.

We have been following this issue for some time and are quite concerned about it.

Our initial concerns were three, and they still remain our significant concerns.

First are the environmental impacts that this would have, particularly on the critical desert tortoise habitat that has been more adequately explained just a moment ago.

Obviously the tortoise is in trouble, and the Coyote Springs Valley is an important area for the habitat of the tortoise, which would apparently and very likely be lost, despite the assurances of a preserve limited to 20 years, which, of course, is much shorter than the millions of years the tortoise has already been here.

The second point is that we question whether or not the public interest is actually served by the loss of this relatively large 80some square miles of Nevada in exchange for a very small area of a few square miles in Florida, an area involving some old tomato farms. Whether or not this in itself is valuable land is questionable. But we are particularly concerned about the exchange ratio being based on what we believe are inadequate appraisals, despite what the Secretary or the Assistant Secretary just said.

There is some property that sold just across the road from the area appraised at $\$ 45$ an acre, which sold for approximately $\$ 400$ an acre, within a few days of the announcement of this legislation.

That raises some questions as to whether or not it is worth really only $\$ 45$ an acre. Perhaps if it is only for grazing and not for development of industrial sites, that might be so.

Senator Hecht. I would ask you to give us any information that you have on that for the record. You will have two weeks to do so. The record will remain open.

Mr. HornBeCK. Certainly. We have copies of the deed and other papers.

Thirdly, our third major concern, and probably the most important, is the rather irregular process which has been used in the approach to this transaction by the advocates of it, particularly the apparent, deliberate attempt to circumvent the National Environmental Policy Act, or at least the principles behind it, by the approach used. That is, Aerojet decided on the land that they wanted, and then went after it, bypassing the Nevada BLM offices and going directly to Washington, as I understand it, and then sought 
legislation directly so as to avoid, as has been stated by the Assistant Secretary, to avoid the need for an Environmental Impact Statement.

I question whether or not Assistant Secretary Horn's statement that the, I think he called it the Environmental Acquisition Report, whether that is the functional equivalent of an Environmental Impact Statement. I submit that it is not, and the copy of it that we have seen is grossly inadequate as an Environmental Impact Statement. Besides that, it was not prepared by the Department of Interior, as he referred to it, as our report. It was prepared by Resource Concepts, in Carson City, for Aerojet and paid for, presumably, by them. At least that is what it says on its first page.

Now, we certainly share the Nevada delegation's interest in economic development and diversification in Nevada. However, I don't believe there is any objective analysis available to warrant or to show that the possible economic advantages may outweigh the real potential, environmental problems. There is really no reason for Congress to jump ahead in this manner without the environmental review that is needed.

There is another point here, too.

Aerojet is renowned for its dismal environmental record in California. It is charged with one of the Superfund toxic waste disasters in the Springfield Acid Pits and also in their rocket fuel plant in Rancho Cordova. So it is not surprising that they want to come to Nevada, where we don't have the kind of legislation that California has passed in their Proposition 65, and our laws are certainly less stringent than California.

Could I have a couple of more moments, Senator?

Senator Hecht. You got 'em.

Mr. HoRNBECK. Thank you.

The particular problems that we would point out with this specific legislation that we would suggest for correction are that the legislation should, as other legislation has, actually require an Environmental Impact Statement to be done by the Federal Government or another independent agency, rather than the proponent of this particular land exchange, namely Aerojet.

Secondly, that EIS should discuss alternative sites and also discuss the proposition or the alternative of no land exchange; that is, purchasing any necessary lands in Florida with the funds available through the Land and Water Conservation Fund and then arranging, if it is necessary, for Aerojet to locate in Nevada, leasing that land to them, leasing the Federal land to them, with the provision that, when they cease their operations at some future date, that land would remain as public lands and revert. That would have the advantages to us of having a way of in perpetuity preserving this area for the tortoises and also for hunting, fishing, and other public use, particularly minerals development, since, as proposed here, this would deed the mineral rights to Aerojet as well.

I see no reason why Aerojet needs mineral rights, other than their future plans to develop this land or sell it.

I understand, I have been told, that Aerojet would agree to a reversionary clause in the event that they did not use the land for this purpose. However, I think if there were such a reversionary clause, it should be an indefinite one, that at any time in the 
future they cease to use the land for rocket testing purposes, it should revert back to the United States, if you go with an actual deed of the land, rather than a lease, as we are proposing.

Finally, there are some specific problems with the land exchange agreement, which are addressed in greater detail in an appendix to my comments. So I won't go into those at this time.

In conclusion, though, I would like to say that we do not oppose land exchanges when they benefit the environment and benefit $\mathrm{Ne}$ vada's environment, in this case particularly. However, we believe that those land exchanges should include the benefits not just flowing to a private corporation, but also back to Nevada by the use of the moneys that this would generate for purchasing Nevada's environmentally sensitive private lands for inclusion in our public lands where it is appropriate, as is proposed to happen in Florida.

If we are to give up public lands in Nevada, then I suggest that we should receive some private lands back through purchase to add to those sensitive areas where they are needed.

Finally, I would point out that what is being asked here is for Congress to abandon the deliberate and sound policy of public involvement in this decision-making process that is embodied in the National Environmental Policy Act. You are being asked to by-pass the policy that Congress itself has established through that act. We urge you not to do that but, rather, to put this back into a situation where a full review, a full environmental analysis and assessment can be done with adequate opportunity for public involvement and alternative study, the study of alternatives.

Thank you very much for this opportunity to testify.

[The prepared statement of Mr. Hornbeck follows:] 


\section{SIERRA CLUB}

330 Pennsylvania Avenue, S.E., Washington, D.C. 20003 (202) 547-1141

TESTIMONY OF DAVID A. HORNBECK

ON BEHALF OF

THE TOIYABE CHAPTER OF THE SIERRA CLUB

CONCERNING $\mathbf{S} .854$

BEFORE THE

SENATE SUBCOMMITTEE ON PUBLIC LANDS, RESERVED WATER

AND RESOURCE CONSERVATION

COMMITTEE ON ENERGY AND NATURAL RESOURCES

June 30,1987

Mr. Chairman and members of the Subcommittee:

Thank you for the opportunity to express the views of the Sferra Club on S.854, a b111 which would authorize the exchange of private lands in Florida for public lands in Nevada.

I am David Hornbeck. I am a native Nevadan and an attorney from Reno, Nevada. Today I speak as a member of the Sierra Club and as a member of the Executive Committee of the Tolyabe Chapter of the Sierra Club. 
The Toiyabe Chapter has over 2,200 members in Nevada and Eastern California. We have been closely following this proposed land exchange since early in 1986. Then, we had three initial concerns which have not changed:

- First, the environmental impacts of a rocket-testing facility on critical desert tortoise habitat and on several species of endangered pupfish dependent on desert springs supplied by the aquifer under Coyote Springs Valley;

- Second, the question of whether the public interest is served in the loss from the public domain of a considerable area of public 1 ands in Nevada (including inltially parts of three Bureau of Land Management Wilderness Study Areas) for relatively unimportant private lands in Florida -- especially where the exchange ratio is based on an apparently inadequate appraisal;

- And third, the irregular process pursued by advocates of this exchange, including the deliberate circumvention of the National Environmental Policy Act (NEPA) and the lack of provision for early public involvement in the environmental studies.

While we share with our Nevada delegation support for economic diversification in the State of Nevada, there has been no commitment 


\section{8}

$-3-$

from Aerojet to actually proceed with this project, and there is no objective analysis that would Indicate that any possible economic advantages of the proposed development would outwelgh the very real potential environmental problems. We see no reason that quick Congressional action is necessary because Aerojet has not recelved firm contracts from the government that would require immediate development of the Nevada lands.

We would like to draw the Committee's attention to a news article appearing June 21, 1987 in the RENO GAZETTE-JOURNAL describing Nevada's first Superfund site in Wells, Nevada. We cite this situation as an example of hundreds of jobs being dangled in front of a small, economically depressed communtty to persuade its officials to issue permits, in this case for a waste disposal plant. Without much checking, officials approved the facility. Subsequently, EPA is spending $\$ 280,000$ to decontaminate a site polluted with 9,000 gallons of organic chemicals soaking into the ground, uphill from the municipal water supply. (Attachment $A$ ).

Nevadans do not want a repeat of this scenario with Aerojet. The unavoidable fact is that the Aerojet has a dismal environmental record. A major polluter in California involved in Superfund toxic waste disasters at the Stringfellow Acid Pits and its rocket fuel plant in Rancho Cordova, it is perhaps not surprising that the corporation wants 
$$
-4-
$$

to move to Nevada. Last October the Environmental Protection Agency denied the company permits to continue pumping hazardous wastes underground at Rancho Cordova. The passage of Callfornia's tough new hazardous waste Initiative, Proposition 65, makes Nevada's relatively weak pollution laws even more attractive to the company.
\end{abstract}

The Sierrs Club recommends a number of changes to $\mathrm{S} .854$ :

1. A full environmental impsct statement (EIS) must be prepared, by a federal agency or other independent source. The private environmental study purchased by Aerojet is critically flawed. The EIS should include an adequate range of alternatives including different sites for the Aerojet facility and alternative mitigation measures for unavoldable environmental and other impacts. Such mitigation measures should include the purchase of environmentally-sensitive land in Nevada as well as in Florida.

2. Such an EIS should consider the alternative of no land exchange at all (with acquisition of needed Florida lands using the Land \& Water Conservation Fund), and the lease and special use permit of Nevada public lands to Aerojet. The lease should be limited to only sufficient acreage for a rocket testing facility and buffer zone, and only for the term of use, if any. If the Coyote Springs site is determined to be the best site for such a facility, we would further ask Congress to add 
these lands to the Desert National Wildlife Refuge with full responsibility for desert tortolse, desert bighorn sheep, and other sensitive species being shifted to the US Fish and Wildiffe Service, rather than merely a 20-year stipulation in the Land Exchange Agreement. Wilderness study areas should be avolded. Hunting and other recreational uses should be permitted to continue unless public safety requires controls. Access for mining exploration should also be permitted, rather than deeding the mineral estate to Aerojet as presently proposed.

3. The "Land Exchange Agreement Between Aerojet-General Corporation and the United States of America" should be rewritten with public review and input to ensure the public interest is served. On page 3 of the current document, a statement that "AEROJET has determined that the exchange of 1 and set forth in this Agreement is in its best interest..." is not sufficient, in our view, to establish that the exchange is in the public interest. Specifically, greater environmental protections, especially of Nevada's deep carbonate aquifer, must be written into the agreement or a special use permit. An analysis of the currently proposed agreement is submitted with these comments detailing problems with its language. (Attachment B). 


\section{1}

$-6-$

In conclusion, the Sierra $\mathrm{Club}$ is not opposed to land exchanges which benefit Nevada's environment. Jeff Van Ee, an environmentalist and a Sierra Club member from southern Nevada, promoted and helped enact Into 1 aw the Burton-Santinf Act which provides for the sale of public 1 ands in Las Vegas to fund the purchase of environmentally sensitive private lands at Lake Tahoe. If Nevada public lands are to be sacrificed for the advantage of a private corporation, then the benefits of the exchange should also include the acquisition of environmentally sensitive lands, In Nevada.

We have opposed seizures of Nevada's public lands by the mflitary, such as occurred on the Groom Range, without due process and compliance with NEPA, including consideration of alternatives and mitigation measures suggested by the public. Likewise, we are opposed to this effective sefzure of environmentally sensitive public lands in Nevada by a private defense industry contractor in exchange for lands of little environmental or other value in Florida.

In this precedent-setting interstate land exchange, involving the lost of approximately 80 square miles of public lands in Nevada for a few square miles in Florida, Congress is being asked to abandon the deliberate and sound policy of public environmental review embodied in the National Environmental Policy Act. We urge this Subcommittee to 
decline that invitation, and to reject this legislation as presently written.

Thank you for giving me this opportunity to testify. 


\section{Toxic scam is first fed cleanup in Nevada}

I280,000 Supertund

\section{project at Wells site}

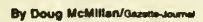

WELLS - The Superfund is coming to Neveda to clean up what environment euthoning scam."

Northern Nevada's first toxic-chem eal cleacup financed by the U.S. Environmental Protection Agency's at Wells. The EPA is spending 5230,000 to decontaminate o site poliuted two years ogo on une northern outskirts of the umall Elko County city by Poly-Carb
Industria Inc. of Medfort, Ore.
Michied Witwerding. himsell as Poly-Carb owner, promised Wells - - mumber equal to 16 entire would hetp tim open a waste recycling plant there.

What be left, wald state and federal environmental officials, whal $8,000 \mathrm{gal}$ the ground uphill irom the mung cop woter supply. Lou Dodgion, edministrator of the stato Eovironmental Protection A peacy, sald the ebemicals - creosol wells, if left to malrate undergre city Creosol, - retative of creasole, is used to the production of synthetuc resins for plastics. Phenol, a component of creo-

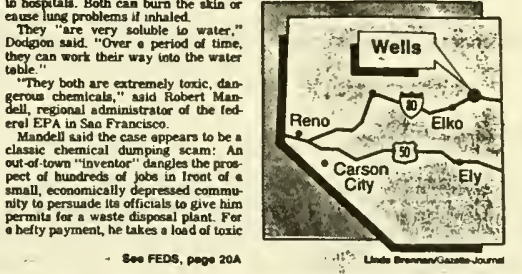

20A-Aeno Gazettevouma

Sunday, June 21, 1987

\section{Feds to begin cleaning up toxic-chemical site in Wells} From pere in 1 af the hands of a compeny
chemicas oft
trying Lo get rid of them illegally. Thes be brngs the stuft to his new "waste reprocessung plant" "where be leaves it eround.

Then be slopes lown.

Wilwerding has oot been seen of
heard from since Poty-Carb filed for bankruptey in Oregor. Mandell said. bave teeo trying to find him. "He's in huding," sand a Poly-Cart employee un Medlord. "Nobody knows where he's at. He cas't be found." The employee said he was unpaid and was stustaling dxe Poly-Cart office in trom the bankruptey.

Wijwerding appears to be the consummate con artist, in more ways than one. outhorties say.

to late 15sh, be mauled e la-foot scale - large still, to demonstrations lo Wellt and Reno. While be fed shredded film. nakes of rubber and pine chips ioto fiery red furnace at ope end, a small
valve at the other end filled coflee rame - with a tooey, blect liquid that wilweent Ing said contained chemicals that could be recycled by the petroleum industry. however, he never brought the much larger worting model be sadd was being

Whise be was coovincing Wells offi. cials to let him set up his operations were, he was seling stock allegedly itle Ban other stales.

Secunties officinls in Oregon ad Montana waot Whiwerding for allegedly relling unregistered shares of Poly-Car

The Cascade County District Attorfiled sis stock-fraud charges agaios Wilwerding, lnciuding two counts of omiserion, giving lalse nod misleading two counts of failing to register stock two counts of selling unregisterod

An eccomplice io the Montana sales.
Cilford Let Allen, was arrested and conveled lor simtlar charges Inst fast. Allen received a to-year atste prison wentence, but sune years of the term relmburse Mootang Investors the stoct. The two counts charging Wilwerding witb omission say he fouled to inform the bryers he was previously conveted for Aecording to Mono County, Calif., records, Wilwerding killed a Chico, Bridgeport in October 1960 after the man threatened to tura whwerding over on police for parole niolodons. Wiwerd beries in Oregon, Utah, Idaho and MinDesols.

nolive encestd say bow long Witwerding was in prison trying to retura hum there.

A Montana judge has issued a warra lor Wiwerding's arrest and a federa. werraot also has been issued, charging prosecution. Leon Beliville, a securities exsminer goo Department of Commerce, said WL2.

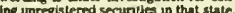
too.

When - coxic spill was discovered in Wells on Memorial Day weekend 19es, wiwerding claimed vendals broke into - metal soed be erected porth of the way 93 and opened the value on his. 9,000 -gallon Lank, draining the chemi. Wells Poltce Chief Chris Dirsmoore Wells Polte Chied Chris Dirsmoore could find oo physical evidence of so ba
loge, however. And that still teft unanswered the question of whit Wilwerding was doing
with loxic chemicals. His recyeling invention was supposed to process oniy non-toxuc wastes such as old movie fitm pinyop scraps. Environmental Proteclion Diviston had given hum an air emission permit, but he had $n$

Under eivil orders trom the division Wuwerding returned to town in Augus 1985 to bulldoze the contaminated ground into a plastic-lined trench on the cials could get him to haul it away

Thet left $8+$ year-old property owrer Judib Birdtell of Whasherton state

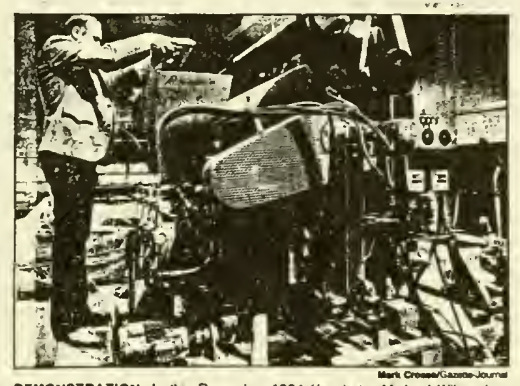

DEWONSTRATION: In this December 1984 hile photo, Michael Wilwerding leeds waste material into a recycling machine. He sad the dence would produce

Iederal low, the tormer Wells resident througb sctivated chercoal filters, could beve been held lisble for the which will be incinerated ot - haxaro-

wousd be no point in taking oction Origanal plans called for simply baul in dime" for the five months be used it, The state filed a civil action ogainst 10.000 . diay Dodgion sasd and be la could be subject to criminal penalles of up to 25,000 a day, plus cleanup coste, The EPA has filed a claim is the Oregon bankruptey proceeding tor the 2av, 000 clesmup costs, bur Mandell adruitted that the prospecta of recovering that kind of money lrom the bank-

whoever geve Wilwerding the waste also could be held liable for the cleanum costs, Mandell said, but the source of the chemicals would be very hard to the ground. expecilly since they leaked loto Environmental Service Inc. of Portland. Ore, the company doing moat Weat Casst Superfund clcanups, will it. ersuly wash the 400 culvic yards ct con's. This week, a crew will dig = bix lwle

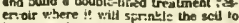
tach nut the creosot and phentol. Then inglil, Masdeth said, bur the EPA decided to be more innovalive "Otherwise, we'd whe from phaer to place. The job shat

Dodion selds ot wicials should conaider themselves goties the Superfund to corne to Wells. te commended lormer Mayor Mire Nennisi, Chy Cowncilwornan Unde ar warting hard to get the cleanum funds. e more careful in trying to check the ackeround of new business prospects. ut une experience has not cooled thet trying to altraet on The whole sity was antbuntautic ebos oly-Carb, nol just the City Counci, "I'm not so stwe that, If the same type of guy came along ... Je'c probubly pe octorve 10 it," he sald. "Rul we'd probanly uske cloner lonk at it. Est. "We were delunitar ised snd atureo. wein 
Subject: Aerojet Bill \& Land Exchange Agreement

From: Jeff van Ee

The Nevada delegation has cosponsored bills to provide Aerojet with over 50,000 acres of public land in Nevada at a value of between $\$ 45-55$ per acres for approximately 4,650 acres of Aerojet land in Florida at a value of approximately $\$ 525$ per acre. Nevada environmentalists have been concerned with the manner in which this land exchange is occurring. It may establish a precedent for future "land exchanges" in Nevada. Opportunities for meaningful public comment have been restricted, and an analysis of the environmental impacts has not been satisfactory with Aerojet contracting out the development of the "Environmental Report."

Your attention is directed to the enclosed "Land Exchange Agreement between Aerojet-General Corporation and the United States of America." I have highlighted sentences and paragraphs in the agreement which are commented in detail below:

Page 2: Aerojet gets the mineral estates in addition to the surface estates at the low cost of $\$ 45$ to $\$ 55$ per acre. Private land at the Butler ranch, across from the Coyote Springs site, sold for $\$ 401$ per acre within a week of the $B L M$ land appraisal of the Coyote Springs site. Private purchases of public lands within Lincoln County have been far more than $\$ 45$ per acre according to BLM records.

Page 3: One would expect language in an agreement involving the transfer of over 50,0000 acres of public lands in Nevada at between $\$ 45-55$ per acre to say that the exchange of land is in the best interests of the United States and the public. Instead, the language states that Aerojet has determined that the exchange of land... is in its best interest.

Page 6: The highlighted statement emphasizes the concern in Nevada that the type of operation Aerojet is proposing can create hazardous materials and possibly contaninate the land since the Secretary of the Interior will be inspecting the land in Florida formerly occupied by Aerojet.

Page 8: Item 9 (a) restricts the United States in entering the land to not more than once per month. This requirement seems to be unusually restrictive.

Item 9 (b) mandates that the United States make all past, present, and future data to Aerojet with the implication that the data is acquired and provided to Aerojet at no cost. One would expect that Aerojet could be required to pay for the cost of obtaining this data particularly if water availability, water quality, and endangered species of fish are issues in the acquisition of these public lands by Aerojet. 
Page 9: Detailed specifications of the construction of a monitor well seem to be given an unusual amount of weight in this agreement. An implication is that future attempts by the U.S. Government to assess the quantity and quality of water in the government would also be highly restricted. Aerojet should be compelled to do the monitoring at their expense to ensure that water quality and quantity is not affected and that no inajor impacts occur to nearby endangered species of fish.

Page 10: A major problem with the proposed "exchange" is that Aerojet may sell all, or a portion of, the land at a later date. The windfall profit would come at the expense of the public because of the artificially low value given to the land by the BLM. The highlighted item [with question mark] covers the situation where Aerojet may chose to sell the land. This possibility is not sufficiently restricted in the proposed land exchange to protect the threatened desert tortoise or nearby endangered species of $\mathrm{fish}$ from future large-scale developments in the area.

Page 11: Item 11 (c) as highlighted illustrates the "hammer" that Aerojet possesses in this Agreement to ensure that they will be permitted to utilize the land for the manufacturing and testing of rocket motors. If anything changes, or they decide to develop larger rocket engines than currently envisioned and someone protests, then they have the right in this agreement to "rescind this exchange." If Aerojet does not get the necessary permits or authorizations at some time in the future from some entity, then they retain in this Agreement the option to stop the exchange. There can be no guarantees with the development of land, particularly private land. There is a risk that future development of property may not comply with local zoning ordinances, or federal, state, and local regulations. Aerojet should be compelled to accept that risk at the time the exchange is executed and be in a position to accept the consequences if anything goes wrong with their developinent plans. If they do not choose to accept that risk, then they should consider another option to the proposed exchange such as a long-term lease of public lands at the Nevada Test site, or continued use of their property in California or Florida.

Page 12 \& 13: The highlighted language covering the "period of time Aerojet makes all or a portion of the Nevada Land subject to a pending sale or option to buy agreement" deserves further investigation and explanation.

Item 12 states that the Department of Interior shall not oppose any application to any federal, state or local government agency for permits . . necessary for Aerojet to conduct activities on the Nevada land that are consistent with the provisions of the Agreement. This provision prevents the Fish \& Wildlife Service from taking necessary actions to protect threatened and endangered species of wildlife that are in the area of the proposed rocket manufacturing and testing facility. Further, the impact of the development of the Coyote Springs land on adjacent BL,Y wilderness study areas cannot be challenged by the Department of Interior if the need arises. This provision in tise Agreement needs to be examined further to determine if $i i$ is legal and precedent setting.

As noted in the Fish \& Wildlife Service memo of December 11, 1986 (concerning the "Formal Section 7 Consultation for Nevada Land Disnnsal"):

The Secretary will withdraw the Services' July 23, 1983 proiest to the 
Nevada State Engineer rendered in response to the application for $55 \mathrm{cfs}$ of water to be taken from resources in Coyote Spring Valley by Nevada Power Company

The Secretary will not oppose the annual use of 4,200 acre-feet of ground water from Coyote Spring Valley by Aerojet

It is interesting to note that the Agreement does not address the fourth point in the December 11. 1986 memo:

The Secretary is granted a Right of First Refusal for 10 years from the effective date of the exchange to purchase the Nevada land, or any portion thereof, if Aerojet makes the land available for sale.

Page 14: Why should Aerajet be offered "a right of first refusal" for the land?

Page 17: It appears that Aerojet is still concerned with the powerline rights-of-way across Coyote Springs even though language addresses the issue in some detail in preceding statements. Aerojet could terminate the agreement. What this would do to the land exchange can be questioned? The presence of Aerojet at Coyote Springs could force a rerouting of proposed powerline corridors through more sensitive areas.

Page 19: It is interesting that Aerojet wants the Secretary of Interior to help lefend the company against native Indian claims for disputed lanis. Perhaps derojet sihould seek other lands that are not contested for their site.

Page 20: No mention is nade of public involvement in an amendment of the dzreement.

Exhibit D, Page 2 of 2: This page demonstrates the lack of water at shallow depths in the Coyote Springs area since every well drilled is dry.

Exhibit F, Page 1 of 5: The Environmental Advisory Conmittee is "window dressing" since its sole purpose is for Aerojet to inform the conmittee of its "construction plans and other on-site activities." Aerojet "shall invite representatives" from azencies and citizens' groups which derojet "may deem appropriate." Aerojet deciles when the connittee will meet. No statement is made about the powers of the connittee hecause the comnittee has no power. If past actions of Aerojet at their Sacramento facility and in Nevada are any indication, citizens can expect to have very little influence over the Corporation's conduct or plans.

Item 2 specifies that the Fish and Wildlife Service in conjunction with Aerojet "in any emergency response plan" give :"specific consideration to measures intended to minimize any harm to federally-listed endangered or threatened species." It is hart to $i$ magine an emergency plan addressing the impact of a rocket explosion or relesse of toxic chenicals on the threatened desert tortoise. Nill derojet send people out to pick up the tortoises or provide then with respirators? Clearly, rocket inanufacturing and testing are ani the peeservation of critical habital for the fesert tortoise pose some talor conficts and strain the effective auminiscration of the Endangered Species Art. 
Page 2 of 5: Item 3 is virtually worthless in protecting the migration habits and routes of the bighorn sheep and the desert tortoise. Aerojet might as well put up signs for the animals warning them of approaching vehicles.

Item 5 also offers linited protection for the "threatened" desert tortoise.

Page 3 of 5: Iten 6 states "Aerojet shall consider" the historical migration routes of big horn sheep. "Protect" or "preserve" would be hetter than "consider."

Iten 8 directs Aerojet to "cooperate" with the BI, in reducing grazing on the Coyote spring land. Since the BLI presently manages the land and adininisters grazing rijhts to the land, it is a curious choice of words on Aerojet's part. Perhaps they are saying that they will buy the grazing rights from the permit holder?

Ttem 9 addresses the establishnent of a "17,885 acre "reserve" for desert tortoises over a 20 year period. After 20 years, a seven member board may approve a change in the usage of the "reserve." Note, no member of the Jeneral public is included on the board, especially representatives of the Desert Tortoise Council. Further, no nrovisions are stated in how the "board will conluci their neetings and arrive at a decision. Looking at the makeup of the board it is conceivable that a najority could easily be assembled to allow the "reserve" to be inanaged quite differently than in the past. Roads, water wells, utilities, facility signs "or other wildlife protective neasures" are some of the peritited uses of the "reserve." When is a "road" a "wildife protective measure?"

Page 4 of 5: Item 10 is perhaps the most disturbing clause in the Agreement. It states that the Fish and Wildlife Service and Aerojet "shall jointly" seek a determination from the Nevada State Engineer as to the cause of a depletion in the water-table which might impact nearby endangered species of fish. Objection is taken to the usage of "jointly." The Fish and Wildlife Service should be allowed to act independently to protect the fish no matter whether derojet is the "sole cause of the depletion of water" or not.

The State Nater Rngineer has previously tesicilel hefore the Nevada Legislatura's Comittee on Public Lands that the capacity of the aquifer cannot be adequately determined because of insufficient dat. Further, he stitel derojet should be allowed to stress the aquifer because that would be a way to determine the capacity of the aquifer. Given the problens that would be created to the nearby endangered species of fish if Aerojet were allowed to develop the site and then find that insufficient water exists, it would seem that the Fish and Wildlife Service should he allowed to act independently to protect endangered species of fish.

Approxirately 460 acres of private land lies across the highway frou derojet. If this land were fevelinged to i great legroe anil the land derojet were tis acquire were al:3o teveloped to a large extint, then the inpict on water availability at Coyote Springs could be severe. What then? 
Senator Hecht. I want to thank you for flying that long distance to testify.

Next we will hear from Jean Perry-Jones.

\section{STATEMENT OF JEAN PERRY-JONES, EVERGREEN ALLIANCE, MOUNT CHARLESTON, NV}

Ms. Perry-Jones. Thank you.

Thank you.

I am from Mount Charleston, Nevada, and I am here today to testify in favor of the National Forest of Nevada Enhancement Act of 1987, S. 59 and H.R. 267. I have several letters that I brought with me to submit for the hearing record.

Senator Неснт. They will be placed in the record. Thank you very much.

Ms. Perry-Jones. Thank you very much.

I am here as a representative of hundreds of Nevadans who could not be here today, Nevadans who have signed petitions, written letters, testified at hearings held in Nevada and reached into their pockets to finance my trip here today to testify in their behalf.

The people in Nevada support the Enhancement Act.

I represent residents of Clark County, including those in Las Vegas and those living in the Spring Mountain range. People living in the Spring Mountain range, who are surrounded by BLM land, from Mount Potosi to the Cold Creek area, want Forest Service expertise and the accompanying Congressional protection for these lands. People in Clark County support the Enhancement Act.

I am also representing the Evergreen Alliance, a grassroots organization formed almost two and one-half years ago, when Nevada was faced with the proposed Interchange and the prospect of losing all of its U.S. Forest Service lands. We support the Enhancement Act.

I am also a member of the Mount Charleston Town Advisory Board, which passed resolutions supporting the Enhancement Act of 1986 and, again, of 1987. These resolutions and supporting resolutions passed by the Indian Springs Town Advisory Board, the Clark County Commissioners, and the Clark County Democratic Party Executive Committee, reflect the desire of southern Nevadans to increase our National Forest acreage.

The Federal Government owns 87 percent of Nevada. Of that, the Bureau of Land Management controls 68 percent and the Forest Service manages 8 percent. Nevadans would like to see the proposed 0.5 million acres of the 48.8 million acres currently managed by the BLM transferred to the U.S. Forest Service management.

The Enhancement Act will enlarge Nevada's existing forest acreage by adding east portions of the Sierra Mountains, Mt. Moriah, and the Spring Mountain Range.

Nevadans, and especially those of us in southern Nevada, feel strongly that the entire Spring Mountain Range should be included in this act, adding Red Rock Canyon and the dominant peak of Mount Potosi to the acreage that you are considering. We would urge you also to include all of the acreages shown on the original 
map of the 1987 Enhancement Act. Those areas should include all of Peavine Mountain by Reno, the Hot Creek Range in Central Nevada, Steamboat Springs by Carson City and Pine Grove.

I have submitted maps indicating the areas to be included.

Southern Nevada's Las Vegas metropolitan area is one of the fastest growing areas in the United States. Its warm desert climate is attractive to tourists and residents.

The Spring Mountain Range is less than an hour's drive from the city, and is the only place of its kind in southern Nevada where people may go to escape the heat, picnic and camp in pine forests, play in the snow, ski, hike by alpine creeks and waterfalls, and climb the rocky peaks.

The range is an important watershed for the Las Vegas valley, providing more than 25 percent of its water. We need the U.S. Forest Service's watershed management expertise to assure our precious water resource for future generations.

We need to save the American taxpayers money by having only one agency manage the Spring Mountain Range.

By increasing Forest Service lands and putting more green on the maps, Nevada can increase its tourism industry. Nevada's great need for economic diversification will be realized more fully as more dollars flow to Nevada from visitors who learn that Nevada is much more than a desert wasteland.

Mining rights will not be affected as BLM continues to manage all subsurface resources on Forest Service lands in the United States.

The only people who oppose this bill are a handful of independent miners. The large mining companies have not opposed the bill.

This bill, however, does not affect the mining claims on any of these lands.

It does not affect the livelihood of the miners, because their mining claims and operations will continue on the new National Forest lands as they did on BLM lands.

Why are these independent miners then opposed to this bill?

The law states that all lands that have been mined shall be reclaimed. This applies both to BLM and USFS lands. The BLM, however, does not enforce this reclamation in Nevada. The U.S. Forest Service, on the other hand, requires a reclamation bond, which is redeemable when the land is reclaimed, thus insuring the restoration of the land.

Reclaiming land is the law, and it is also in the best interest of Nevadans. Reclamation restores the land for grazing, keeps the water from becoming polluted, restores the wildlife habitat, and reestablishes outdoor recreation esthetics.

Since the Forest Service does a better job than BLM at reclaiming the mined land, this is yet another reason for passage of this bill.

Water rights, the stumbling block for the 1986 Enhancement Act, should be resolved now. I would suggest to you the language developed by the National Task Force of Nevada. Under Section 8 of the current bill, "Water Rights," deleting item (b) and replacing it with the new wording as I have submitted in my testimony. I won't take the time to read it now. 
Another alternative for water rights language would be that which was marked up last week from this Subcommittee on the El Malpite National Monument in New Mexico. Since the Nevada Enhancement Act, an El Malpite bill that had similar water rights issues, similar language solutions could be used. There is also the example of water rights language used in Nevada's National Parks bill.

Nevadans are not that concerned about exact water rights language, as long as a compromise is reached in a timely manner to facilitate the expedient passage of this bill.

Nevadans want more U.S. Forest Service land put aside as an investment for future generations. Whereas the BLM's district offices may dispose of public lands as they see fit, USFS-designated lands remain intact, unless altered by Congress.

We, in Nevada, trust you, as our Nation's leaders, as custodians of our national heritage, to bank savings of resources for generations of Americans yet to come. It is for these reasons that we Americans who live in Nevada also feel that all the forest lands in the United States should be preserved as U.S. Forest Service lands for all Americans to enjoy in generations to come.

The prime lands must stay in the public hands throughout the United States. We are assured that holding only under U.S. Forest Service management. Transferring any of those lands to BLM, including those acres of USFS lands to be transferred to BLM in the proposed Interchange, allows that agency to dispose of the lands at their district office's option.

Please keep USFS lands intact. I urge you to unanimously pass the Enlarged National Forest of Nevada Enhancement Act as expediently as possible and to encourage its timely passage through both legislative bodies.

Thousands of Nevadans are counting on you and millions of Americans are counting on you.

Thank you.

I have some testimony also for the Aerojet proposal.

Senator Hecht. Thank you. I know that, but I have let you go several minutes over your time. Rather than just read it, why not just take a couple of minutes to summarize it. Your statement will be a part of the record.

Ms. Perry-Jones. Okay.

Basically, I was testifying against the Nevada-Florida Land Exchange Authorization Act. Having been little publicized in Nevada, as I stated, the more Nevadans I spoke to, the more vocal their indignant replies had become. They didn't see it as a land exchange. They didn't see Nevada's land being worth 12 times less than an Everglades land. Although the Everglades is environmentally necessary land in the United States, so is Nevada land. Where they can go right in and use the arid Nevada land, they would have to do some change on the wetlands in order to even use them. So this also increases the value of Nevada's land.

Problems with pumping water, asking for water rights, on an issue where, in the West, it has triggered many battles before, where they are asking to pump up to 2 million gallons a day of pure, pleistocene aquifer water, and we have a real problem with that in the arid West. We feel that the growth of the Las Vegas 
Valley is going to be needing that water in future years. It is a resource that has not been shown that it is going to be replenished. It is also an aquifer that goes up under other States as well-Idaho, Utah, and Arizona.

We have made the mistake before of pumping water in Texas, and it has depleted Nebraska's water and lowered its water table. We don't need to make this mistake again.

Once again, environmental impact studies should be done, as well as hearings held in Nevada, to make the public aware of this bill and to see if the public really wants 200 more jobs created at the expense of several thousand Nevada acres.

Thank you.

[The prepared statements of Ms. Perry-Jones and letters for the record follow:] 
SUBCOMITTTEE ON EUBLIC IANIDS

TESTIMONY FOR THIE JUNE 30, 1987 HEARING RECORD

S 59 NATIONAL FOREST OF NEVADA ENHANCEMENTT ACI

Jean Perry-Jones, 30 Aspen, Mt. Charleston, Nevada

I am here today to testify in favor of the National Forest of Nevada Fnhancement Act of 1987, S59 and HR267.

I am here as a representative of hundreds of Nevadans who could not be here today: Nevadans who have signcd petitions, written letters, testified at hearings held in Nevada, and reached into their pockets to finance ny trip here torlay to testify in their behalf. People in INevada support the Fnhancerent Act.

I represent residents of Clark county, including those in Las Vegas and those living in the Spring Mountain Range. Pcople living in the Spring Mountain Range who are surrounded by BLM land, from Mt. Potosi to the Cold Creck area, want Forest Servicc expertise and the acoompanying Congressional protection for these lands. People in Clark County support the Enhancement Act.

I am also representing the Evergreen Alliance, a grassroots organization formed almost two and one-half years ago when Nevada was faced with the proposed interchangc and the prosipect of losing all of its us Forest Service lands. We support the Enhancement Act.

I am also a member of the Mount Charleston Town Advisory Board which passed resolutions supporting the Fnhancement Act of 1986 , and again of 1987. These resolutions, and supporting resolutions passed by the Indian Springs Iown Advisory Board, the Clark County Commissioncrs, and the Clark County Democratic Party Exccutive Comattee, reflect the desire of Southern Nevadans to increase our National Forest acreage.

The Federal Govemunt owns 87 percent of Nevada. Of that, the Bureau of Iand Munagement controls 68 percent, and the Forest Service manages eight percent. Nevadans would like to see the proposed .5 million acres of the 48.8 million acres currently managed by the BIM transferred to the U.S. Forest Service managenent. The Fnhancemont Act will enlarge Nevada's existing forest acreage by adding east portions of the Sierra and Ruby Mountains, Mt. Moriah, and the Spring Mountain Range. Nevadans, and especially thosc of us in Southern Nevada, feel strongly that the entire Spring Mountain Range should be included in this act, adding Red Rock Canyon and the dominant peak of Mount Polosi to the acreage you are considering. We hould urge you also to incluci all acreages shown on the original map of the 1987 Enhanncoment Act. These areas should include all of Peavine Mountain by Reno, the Hot Creck Range in Central Nevada, Steambat Springs by Carson City, and pine Grove. I have submitted maps indicating areas to be incluclect. 


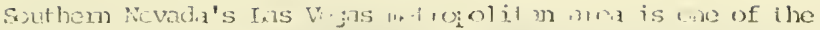

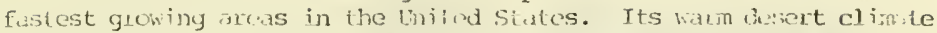

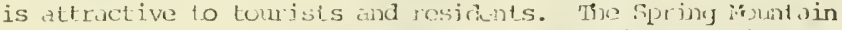

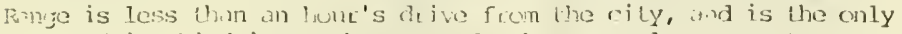

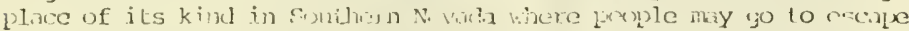
the heat, picnje and corpe in pine forists, pr.iy in the snuiv, ski, hike $b_{y}$ alpine crocks and raik[alls, and c] inb the roky peaks.

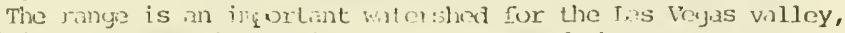
providing mie them 253 of jts witer. Wi nud the U.S. Forest

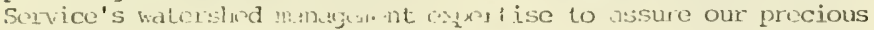
water resounce for fliture grinlations.

lie need to save the Mrrican taxpayes noncy by having only one agency manage the Spring bumtain Ranize.

By increasing Forest Survice lamis and putting nore green on the maps, Nevada can increase its Lourism industry. Nevada's great neod for ecomonic diversification will be realized nome fully as nore dollars flow to ivervala fiom visitors who lean that Nevada is much more than a clesert wastel.und.

Mining rights sill not be affected, as the BIM continues to manage all substrface resources on Forest Service lands in the United States.

Water rights, the stimbling block for the 1.986 Fnlancomont Act, should be resolved row. I would suggest to you the following languaye, as developed by The National Forest Task Force of Nevada. Under Section 8 of the current bill, water Rights, delete item (b) and replace it with this ncw item (b) wording:

(b) Nothing in this Act shall be construcd to establish a now express or inplied rescrvation to the United States of any water or water right with respect to the land described in the Act: Providod, that the United States shall be entitled to only that express or implied reserved water right necessary and limited to primary purposes of the land transferred to Forest Service jurisdiction and further limitod to those minimum quantities of water requirod to carry out the primary purpose of the reservation. Any such right carrics a date of priority of the date of enactment of this legislation. Further provided that this transfer shall not result in any adverse affect or impact on existing water rights.

Nevadans want more U.S. Forest Service lands put aside as an investnent for future generations. Whereas the BLM's district offices may dispose of public lands as they see fit, USFS-designated lands remain intact unless altered by Congress.

We in Nevada trust you, our nation's leaders, as custodians of our national heritage, to bank savings of resources for generations of Americans yet to come. It is for these reasons we Americans who live in Ncvada also feel that all the forest lands in the U.S. should be preserved as U.S. Forest Service lands for all Americans to enjoy for generations to come. 


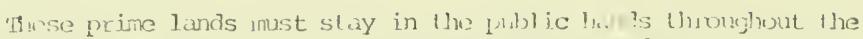

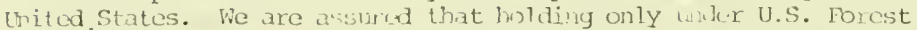

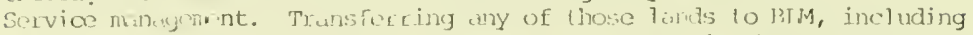

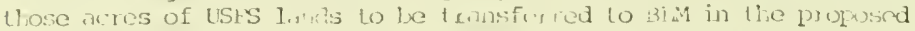

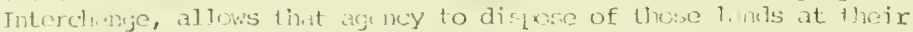
district office's option. Ple, ise kerp lists lands int ket.

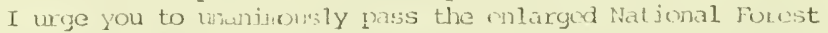

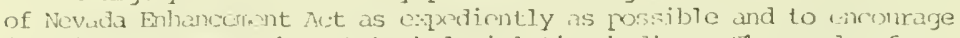

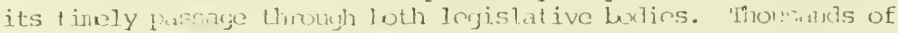
Nuvadans are count ing on you. Millions of wineticans are counting on you.

Tilank you. 


\section{5}

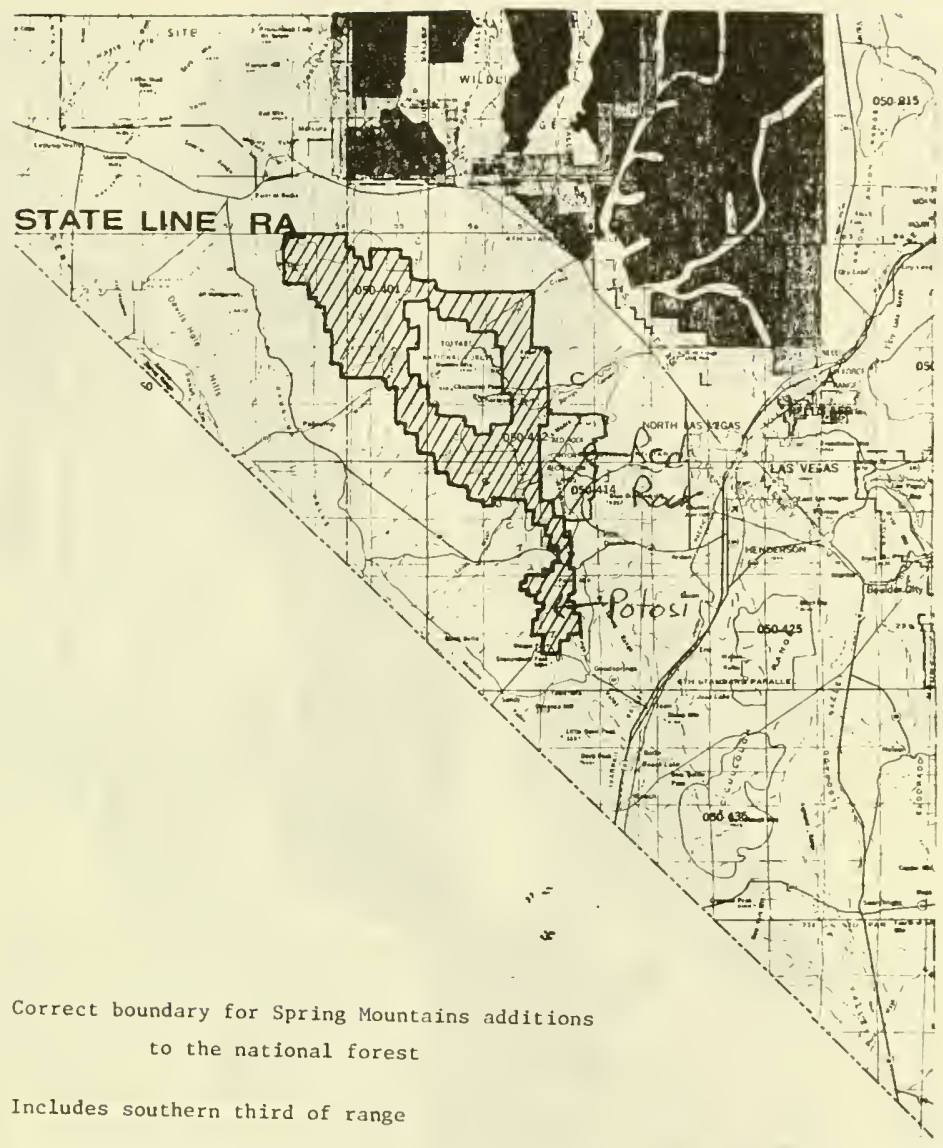

ExcIudes Red Rocks 


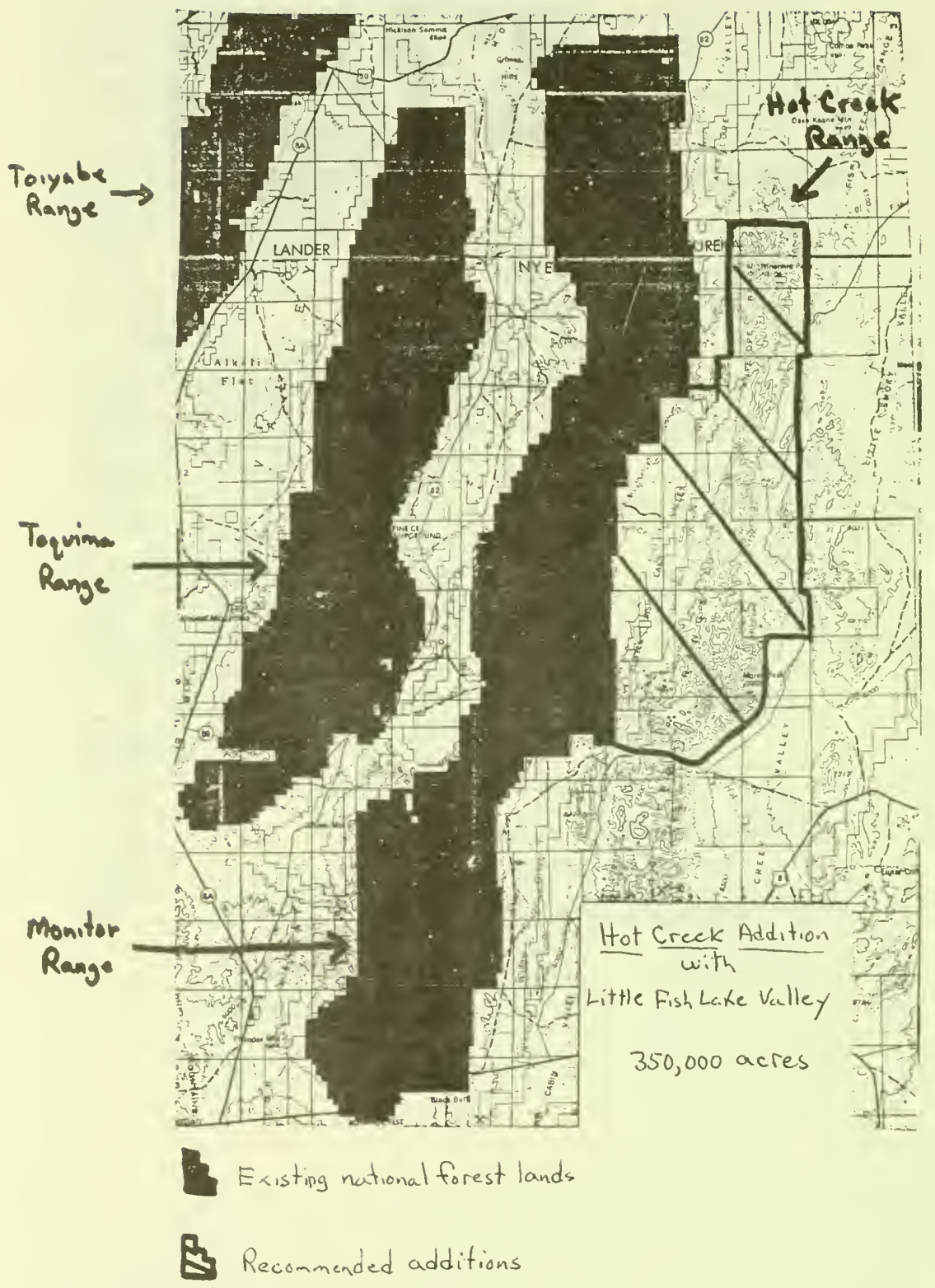




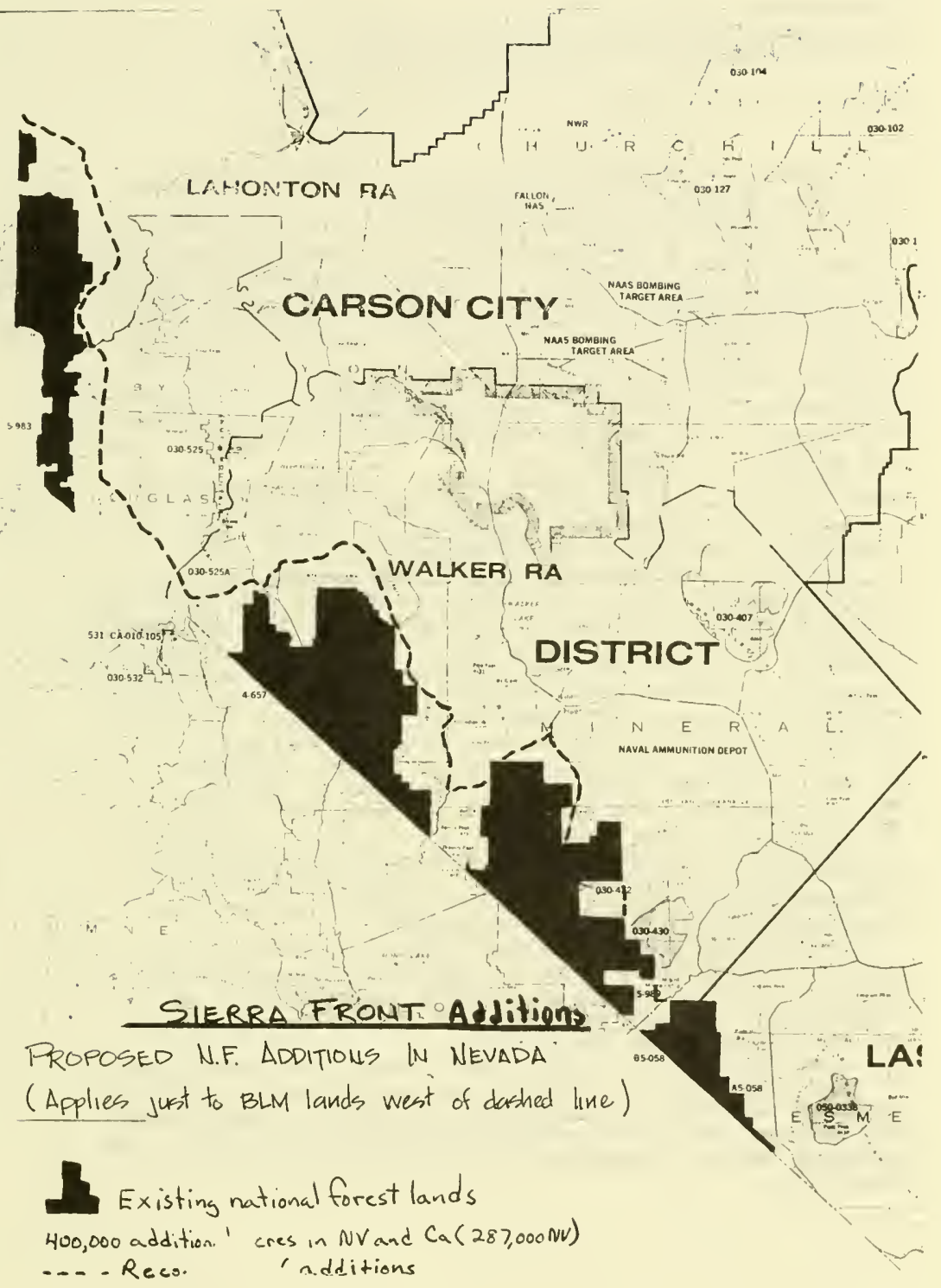


S UBCONMIITEE ON PUBLIC LINDS

THESITINONY FOR THE JUNE 30, 1987 IIEARING RFCORD

S 854 NEVADA-FLORTDA IAND EXCIANGE AUIJORTZATION ITCT OF 1987

Jean Perry-Jones, 30 Aspen, Mt. Charleston, Nevada

I an here to testify against the Nevala-Florida Iand Fuchanye Authorization Act of 1987, S854 and HR1845.

This seems to be a little-publicized act in Nevara, horever the more Nevadans I speak to, the more vocal their indignant replies beome. Nevadans are appallod at this unejualled "Land Exchange."

Nevada is not a vast desert wasteland, good only for gunbling and weapons testing. Nevada has its descrts, but the only wastelands are those that have been bombed and nuked beyond habitation by man. Nevada is a beautiful state, with mountains, forests, wildlife, and the spaciousness of a last frontier. It is a state for dreamers, explorers, and settlers. Nevada attracts thousands of Americans as new residents each year, and its metropolitan areas are growing at an astounding rate.

Florida, too, is a beautiful state. Its wetlands certainly need to be preserved for their wildiffe and ecological importance. However, Florida swamps are not worth twelve tines the value of Nevada's land, and that is the "exchange" equivalency.

Aerojet is also asking for water rights, an issue that has triggered many a battle in the arid west. The water they want rights to is a deep carbonate Pleistocene aquifer, which runs through the states of Idaho, Utah, Nevada, and Arizona. Recent hydrological studies of the aquifer have been unable to discern when and if the aquifer is replenished. It has not yet been tapped as a single water resource in any significant amount. Yet, Aerojet is currently planning on pumping 2 million gallons per day of this pure water source in a desert envirorment to use for industrial purposes.

We have seen the devastation of lowered water tables in Nebraska from water taken from aquifers in Texas. We should be able to learn from past mistakes.

Furthermore, immediate results from using 2 million gallons per day would be the likely stagnation and destruction of the Pahranagat Wildlife Refuge and the elimination of one of the few desert wetland habitats and breeding grounds.

The Ias Vegas water supply would also be threatened by the tapping of the aquifer. As the Las Veyas area continues its rapid growth, it will need to have all of its resources available as the waters flow to the Vegas valley, and not have the flow shut off by such extravagent demands for its water.

Nevadans also fear Aerojet's track record of land mismanagement, as was evidenced in the Sacramento area. Rather than correct their problem of polluting the Sacramento water supply in a timely manner, they increased the problem by expensive and long court battles. The lawmakers' hands were hopelessly tied while Aerojet played out the legal system. 
Should the BL:1 wish to exchange ils land holdings for the national grood, it should le for lhe goul of all states involvad in the trensfer. nerojet can do inre on dicy Nevar?a land than it can in Florida Siving lasd. Novala land slould we iual in value, if not nore valuable, to Acrojet. An acre-for ecre cxchajge is more equitable. And der.rt avellers an't give up the is siter rights.

Fuvironental Theact Si wies :hould certainly be done, and relcosed to the public for luview. In actition, tiris bill should be given public hearings in soveral locations in :icvara, around the sights plolised.

Many Nevadens fecl that there is enough military and weal ons testing and arsenals in Nevada. One more major installation, although private in nature, is just one iure land grab from the people of the state, a state in wich 87 reent of the land is fererally controlled. Nevada's land is morth rore than $\$ 45.00$ an acre, and Nevada's

land is worth more than to be used as a boubing and testing range. Pleuse allow this Lund Exchange to die. Thank you. 
160

June ne, 1987

De as Sub-Commitice Chairman:

$2^{\circ}$ strongly support SR .59 a dO HR 267, national Forest of Nevada Enhancement act, including the areas of Red Rock Canyon and int. Potaxi, Nevadans continually get shout-changed by big-govesnment ans big business - trying to pass resolutions to further take array our lane and tin aus state into a military testers, ground and a nuclear wasteland. We need to take charge of ow s own state, and preserve the natural enviconinent of os in fragile decent.

Corrie languor $5680 \mathrm{~N}$. Jo nos Laslegas, NV 89130 
161

-)ence $26,198 \%$

Hear Such- Commethe Channan:

- warld like te lend my

oupport to SR59 and HR267 -

Thational Jorest of Mevada Enhancement

lect, + also yolease include

Ped Rock Canyon * Mt Patari.

Thank you,

Margaret Hargou 187 Sumnit Ureir Circle $M+$ Charleston, Mevada 
162

Dear Senate Subcommittee;

I live in Mi Charleston Nevada ant love the treesund wildlife here. I want you to know, I fully support the "Notional Forest of 'Nevad al Enhancement Act '(559+HR.267) Our forests in Nevada are beautiful? lets keep them way, for your family

$$
\begin{gathered}
\text { Mr }+ \text { Mrs M Tobola } \\
\text { Star Rt } 38 \text { Box } 284 \\
\text { Mt Charleston, New ala } \\
89124 \\
1-702-8.2-5243
\end{gathered}
$$


163

Suncty s.

An Pra Chairman:

c1 Peare submit this lette fow Dubli recorf:

1 supper Nó Drationgl Touxt of zonale Exhanement act. Thw is a pationel entrensermet, siting aside 7fencada fored bor all of Amerer to espoy. comsich atron on this bill

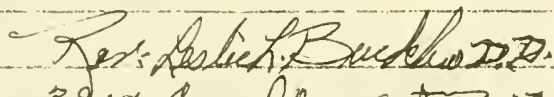
3917 Comalls at at B:17 efing Valley Cab 9201" 
164

Jane 26, 1987

Dear sub-Committee Chirmon: I would like to lend my suzper t
to SRSG and HR 267- Mtionel foreat of Nevada Enharcement act, at aloo Plase include Red Roch Conjor of mt Palosi

Shartyou Jeh UThoma ANO DR. LAS VUCAS, NU 89131 
165

dune.23, 1987

Dear Sulcommittee Chaiman:

coupport of 59, The Mational Torest of Meevada Eunancoment Act. difecl alt Americans would benetit by incicasing aw Mationd trests' acreage. (Peciada has thousands of acces of beautglul forest lands which should be presewed for future gequations:

Glease include all of Mtt

Potose, Red Reek Panyor, and

Heavine in \& $5 \%$

Thankyow ofor your action.

Aincenely yeuca Cyntace Hal 5017 Carmen Blud, Las Vegas Nerada 89108 
166

Dear Senate Subcommittee

Re: Ylational forests of nevada Erhancerient $a_{c t}$ (HR. $267-5.59$ )

I un in support of the national Forests of nevada Act and would like to see the
me. Potasi area included.

We must act now to preserve our Forests and Wildlife with the large population increases facing our state in the rear future.

Thank yon

Sub anne Kaime Leo 101 Daises Drive int. Charleston Munda. 89124

702.872 .5757

Secretary: Mt charleston Tour Advisory Band. 
167

June 23, 1987 The National Forests of Nevada Enhancement Act

Dear Senate Subcommittee:

$D$ am witenig this letter to lack for your support of the National Forest of I nevada Act including the Int. Potosi

D have lived in Mt. Charleston for ten years and racing three children. D fuel it is very vital. for the future of my family, and the preservation of wildlife.

Thank you, Ami jo villains Box 358, HCR 38 Mt. Charleston, thu. 89124 $702-872-5482$ 
168

lune 24, 1987

Dear Subcommittee Chairman:

I support \& 59, The National Forest of Pervade Enhancement Act. I feel all Americans would benefit by increasing our Nations Forests acreage. Nevada has Thousands of acres of beautiful forest lands which should be preserved for future generations. Please include all of Patosi, Red Rock Canyon, and Peavine in $\$ 59$.

Thank e for your support. D am a young man who really cares about conservation and $d$ would like to be able to someday being my child un to these spacious and beautiful areas. Thank you again for your time.

Sincedy,

Charles 2 Palmer

Sops newbedford Dr

Las Vegas, NV. 89121 
169

Guer 22+1987.

Dear Mr. Chassman,

A suppert 5.59-National tount of Wevada Enhanament tet please also inchel hed Rxk Canyon and Nt: Potosi

Than you for you actin

Sandra Li Bunder 204 Rraldly.

Las Veges Nu 89110 
170

quine 24, 1987

Lean Subcommider Chairman:

6 support 559, The 11 atonal Foxes of Prada Entancenunt act. O fuel all Americans will benefit from this. Prada hoo thousands of acreage which should be taken care of for future generations.

Please include all of Mt. Parsi; Led hoot Canyon, and Ravine in 559.

Thant you for your support.

Sincerely,

Teri pittas 2917 Colansthe Las Llegas, yow. 89102 
Senator Hecht. Thank you very much.

Charles Watson.

\section{STATEMENT OF CHARLES S. WATSON, JR., DIRECTOR, NEVADA OUTDOOR RECREATION ASSOCIATION, INC., CARSON CITY, NV}

Mr. Watson. Mr. Chairman, my name is Charles Watson. I am Director of the Nevada Outdoor Recreation Association in Carson City, Nevada. We wish to address both Senate Bill 59 and Senate Bill 854 in these proceedings.

I have previously submitted the statement which you have up there, and I will try to be brief and summarize those comments. I won't read them iri detail.

Senator Hecht. Thank you.

We strongly oppose Senate Bill 854 because it undermines the Federal Lands Policy and Management Act reforms of the past malpractices, such as the Curtis-Wright Land Exchange of 1961 and the Point Reyes fiasco of 1969 in interstate land exchanges.

Aerojet presently has no Pentagon contract that we know of that justifies this land exchange. Yet, they seek a creation of a land base from our public lands in order to have a leg-up on the competition.

In this case, high Interior officials and Aerojet have conspired to suppress key environmental laws, and we can document this in many instances-for instance, by attempting to promulgate withdrawals without required Section 7 Endangered Species Act study. This was attempted in 1985.

When they realized they had to do the Section 7 study, then they proscribed the Fish and Wildlife Service in Reno from releasing a true jeopardy opinion, citing a clear danger to the 14 Category One and Category Two species in the Coyote Springs Valley area of Nevada.

Aerojet has altered the Florida offered land scenario four times, with no NEPA analysis whatsoever done on that process. The Florida lands are not critical habitat, whereas 42,800 acres in Nevada definitely is.

Aerojet has involved itself in two serious Superfund scenarios and now has refused to cooperate with the EPA in the clean-up at Rancho Cordova, California. The taxpayers will all have to clean that up. They are also involved in Stringfellow, California.

Aerojet is intransigent on the whole idea of alternatives in this regard. We have suggested five alternative sites in Nevada that might be studied under a full EIS scenario. The BLM has illegally been barred from scoping, from holding hearings, from involving the public in decision-making. The bill is tied to a memorandum or understanding that targets known critical habitats, fossil water, with no recharge, in five unique wilderness study areas that surround this valley, four of which have been recommended by the agency.

The National Environmental Policy Act would be shattered by a Congressional failure to assess the impacts and alternatives required by a comprehensive Environmental Impact Statement.

The BLM's appraisals are flawed. We can document the fact that $\$ 45$ an acre is offset by comparable sales in the area, ranging from 
$\$ 401$ an acre to $\$ 6,000$ an acre for comparable land, of undeveloped rangeland of that kind.

In regard to Senate Bill 59, we have some very short comments as well.

The Nevada Outdoor Recreation Association, at the request of Scot Cameron, of your office, Senator Hecht, produced a comprehensive report of our views and recommendations concerning Senate Bill 59. I request that the report be made a part of our testimony by reference, and I have a copy of that right here, Mr. Chairman.

Senator Неснт. Without objection.

Mr. WATSON. Regretfully, NORA must go on record as opposing Senate Bill 59 as it now stands. However, we feel that there are conditions under which we could support it.

In order to have that support, significant changes must be made regarding permanent protection for wilderness and areas of critical environmental concern that have so far been identified and recommended by the BLM and proposed by conservationists.

Specifically, three BLM wilderness study areas, as recommended by the BLM as suitable in Clark County, should have permanent wilderness protection as a part of this legislation. They should become part of the National Wilderness Preservation System.

Further, four areas with a measure of BLM protected designations in the Spring Mountains at the present time, and four additional areas not now enjoying enhanced BLM protection must receive permanent area of critical environmental concern, or what is known as ACEC, protection inside the legislation, or mandated by Congress as part of the legislation. Otherwise, we cannot support it. It is simply BLM-bashing.

As you know, our prime purpose-and we have been in business for 29 years, we fathered the BLM Organic Act, we are concerned about the implementation of that legislation-we believe the BLM can be made a good manager of these lands. However, in some instances we think maybe an adjustment has to be made for Forest Service situations. I agree that it can be done. We can support this legislation, provided these changes are made.

Thank you, Mr. Chairman.

[The prepared statement of Mr. Watson follows:] 
June 30,1987

NEVADA OUTDOOR RECREATION ASSOCIATION, INC.

NATIONAL PUBLIC LANDS TASK FORCE P.O. BOX 1245

SOLTHWEST WILDLNOS EDUCATIONAL INSTHUTE INORA) Carson City, Nevada

founded 195s

Charles 5 Walien, Ir

ith in Skitan

Uurwin Lunitwer!

Lurav, bustint

Bill Vimest

Las tetass. Nevesed

lett ban E.

- lequas Neveda

thowars Bhwih

Las bromas verade

Albert "Sam" Angove

Hanilu a Manirus

Hugh C MeNillun

Gediurd. Aen turk

C. Chrtum lusung

Rethers I'vugh

verw lurt. Ven ivith

Manurie Sill

Reno versed

Mahwel Frume

Muscun ldah

Rutherd Ravmunas

Mento Purk Colltom

Russell Pengertly

Bums. Unegur

Jathes a Corbet

Kiondike, Artzon

Cletsum R Mermi

Denver, Culucado

Res and Mlurier Lum

Lawnvilue, Nevada

Dr Richard Bargen

Gabbar Nenaga

Wulluam Mriners

Buse. Istho

Thuron Lane

curraro. Anzom

Amis Miszes

Rorcos Poland

Sea Ranch. California

Runger Sitholl

Renu, Neves

Drummond Pike

San Francisacio. Calituma

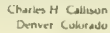

Charkes Hi Sincldard

Vimurize hisunsin

Paul Cliffore

Clencland Heighis, Otro

Harres Allen

Sen theso. Csithossis
HONORARY LIFE MEMBERS

Spokane. Washingto

\section{Senator Dale Bumpers(Arkansas)}

Chairman

Senate Energy \& Public Lands Subcmte. Dirksen Senate Office Building

Washington, D.C. 20510

Dear Senator Bumpers/Subcommittee members:

This organization is regarded as the nation's oldest U.S. Bureau of Land Management(BLM) Public Lands environmental advocacy.

Founded in 1958, "NORA" fostered key provisions of a "mandate" that eventually became the Federal Lands Policy \& Management Act (FLPMA). I co-authored the book "The Lands No one Knows", which played a role in enactment of the BLM Organic Act (FLPMA).

The Nevada-Florida Land Exchange Authorization Act(S. 854) is not so simple a Bill. We can tell you true horror stories about the Curtis-Wright case(1961) and the Point Reyes Exchange(1969). These are still notorious examples of what led Congress to forbid interstate land exchanges in FLPMA in 1976.

This Bill epitomizes the kind of "sweetheart" land deal that has the ultimate goal of "privatization" of our Federal lands. A great deal is more at stake than 42,800 acres of primeval Sonoran Desert wildlands in the Caliente BLM Resource Area of SE Nevada. Documents provided by Aerojet may actually belie the rocket testing aspect of this takeover. S. 854 is a "fast track" vehicle past our major environmental and protective land laws. Most grievous is the fact that this is a significant action affecting the environment.

Illegal tactics by high Interior Dept. officials--to smash environmental regulations--are involved here. We know, first hand, of telephone calls to U.S. Fish \& Wildlife Service field personnel saying: "you're out of control; we don't want to hear about rare species". We can document related incidents, including an atternt to withdraw BLM lands without the required Section 7 Endangered Species Act study. Later, FWS produced a "jeopardy opinion" that depicted a threat to 14 Category I and II species in the region. This was quashed. A Sacramento Bee FOIA inquiry proved this in 1986. Indeed, there was a FWS study showing that desert tortoises had undergone a 50\% die-off in the region in 1980-85. Instead of enacting S. 854, what is needed is a Congressional investigation of Assistant DOI Sec. Bill Horn and Federal FWS liaison Steve Robinson.

Over the past 2 years we've seen a shell game played with offered lands in Florida. It started with 12,000 acres of tomato farms that were supposed to benefit Everglades National Park. A couple shifts later, it became 4,600 acres of bone-dry brushlands. We have investigated the latter. It has no critical wildlife habitat. of the two environmental analyses done by Aerojet(alone), there is no volume on the Florida offered lands.

We have supported land exchanges. We helped realize enactment of the Burton-Santini Act--which is now helping save environmentally sensitive lands in the Nevada-Calif. Lake Tahoe Basin. (continued) - in memoriam :.

INORA Founders

\begin{tabular}{|c|c|c|c|}
\hline sumner L Evans & Lnotge Lund & Einest fohnown & fumes 6 Huls. St \\
\hline & Lnunuilk Verdes & Empure. Anuste & thunter. Teroda \\
\hline & Charies Ragu & Humastd Dethan & Ruthatd Holme \\
\hline
\end{tabular}

NTrTr tounden

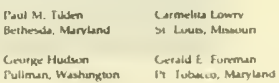


Vicvada/Elorida Land Exchange Authorization Act(S. 85/) page three

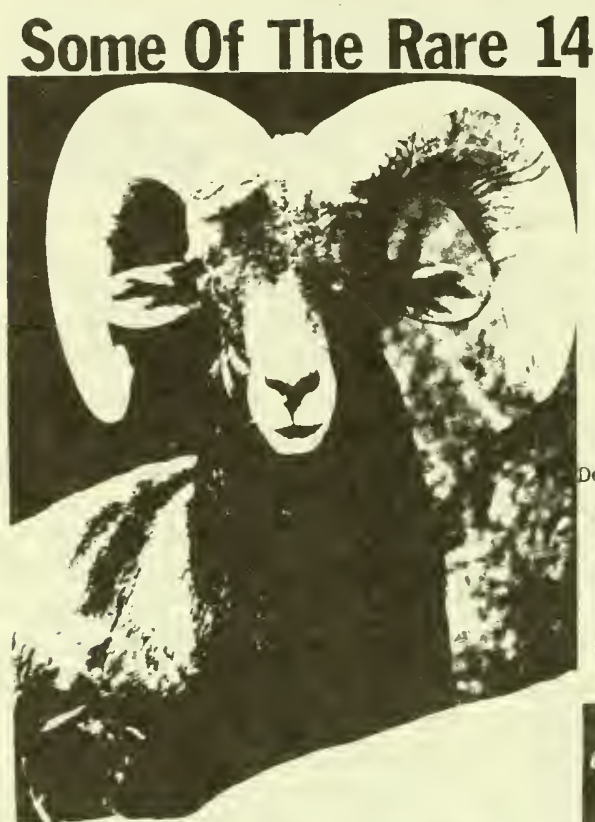

Species Impacted

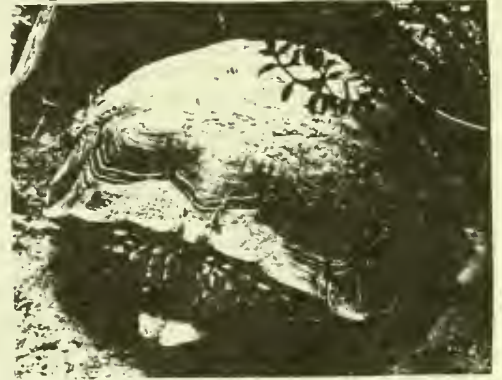

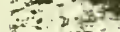

Desert tortoise--a NV protected species

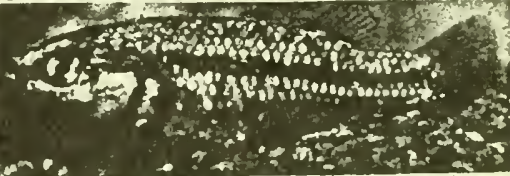

White River Spring, ish(Crenichthys

baileyi thermophilus)--endangered.

Nelson's desert bighorn sheep--Aerojet would cut off 2 migration routes.
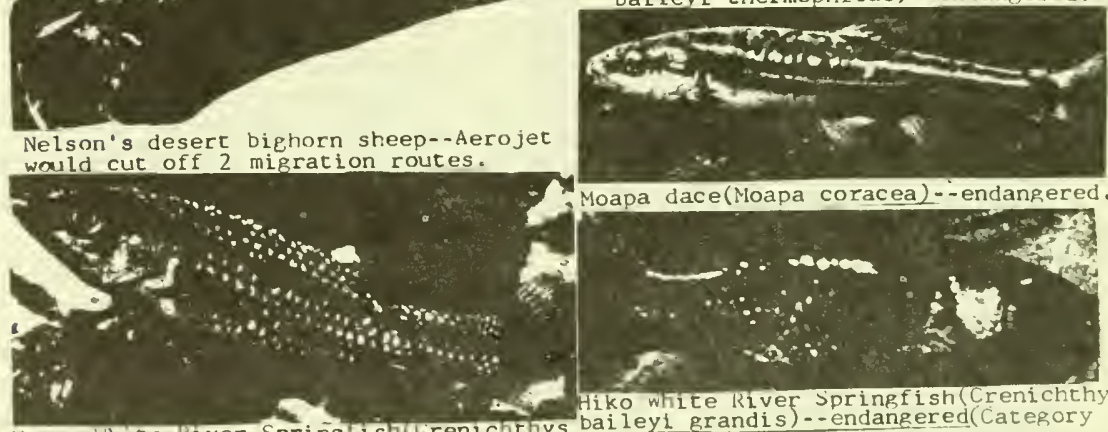

baileyi moapa) - -threatened (category II)

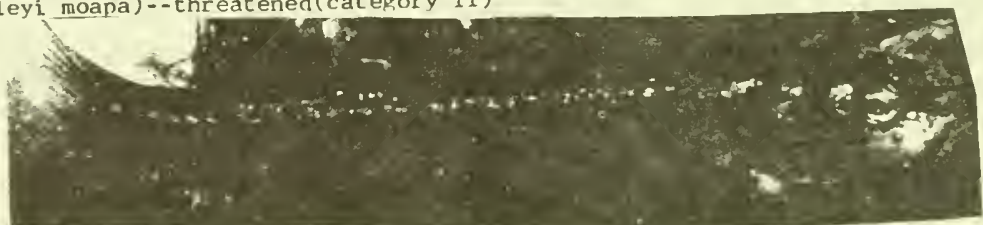

Specked dace(Rhinichthys osculus)--threatened(Category II) 


\section{June 30,1987}

PROPOSED AMENDMENTS AND ADDENDA

\section{NATIONAL FORESTS AND PUBLIC LANDS OF NEVADA} ENHANCEMENTS ACT OF 1987

$$
\text { S.59 }
$$

SUBMITTED PER REQUEST OF MR. SCOTT CAMERON BY NEVADA OUTDOOR RECREATION ASSOCIATION

Apri] 28, 1987

$$
\text { REPORT on } S-59
$$

for: Senator Dale Bumpers (Ark.)

Chairman

Senate Energy \& Natural Resoures

Subcominitter

Dirksen Senate Office B!dg

Washingtor, D.C. 20510 
Mr. Scott Cameron

Assistant to Senator Chic Hecht of Nevada 302 Hart Senate office Building washington, D.C. 20510

Dear Mr. Cameron,

Please find submitted herewith the proposed amendments and addenda prepared at your request by the Nevada Outdoor Recreation Association pertaining to Senate Bill 59, titled the "National Forests and Public Lands of Nevada Enhancement Act of 1987".

We submit our suggestions in this form not to presume upon the prerogatives of the senator, but rather in a spirit of cooperation. Should any of our suggestions be acceptable to the Senator, we hope that the submitted format may be of some use. We apologize in advance for the long dissertations on meets and bounds, but that is the only way to truly describe the areas under consideration. It also seems to us that good tight descriptions, like vermont stone fences, make for better neighbors, and better management.

Finally, you may note that the road numbers submitted in the proposal are those of BLM maps as follows: Wilderness status Map (June 1986), Public Lands Guide, Las Vegas District Nevada (undated but latest version available), and Surface Management Status Maps (scale 1:100,000)for the Smith Valley Quadrangle (1978) and Carson City Quadrangle (1975). You should be advised that the state of Nevada has changed a number of route numbers, and at least the following have been affected: \#3 has become \#208; \#31 has become \#359; \#16 has become \#160; the northern portion of \#39 in the Desert View Natural Area has become \#156; and the southern portion of \#39 in Kyle Canyon has become \#157.

We are grateful for the opportunity to be of assistance, and hope you find our suggestions acceptable. If we can add any clarification or be of any further assistance, please feel free to contact us.

Chace S btotsm, h

Charles S. Watson, Jr. Director

P.O. Box 1245

Carson City, Nevada 89702

(702) 883-1169
Sincerely,

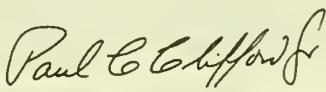

Paul C. Clifford, Jr. Special Consultant 2955 Berkshire Road Cleveland Heights, Ohio 44118

(216) 371-2749 
PROPOSED AMENDMENTS AND ADDENDA
NATIONAL FORESTS AND PUBLIC LANDS OF NEVADA ENHANCEMENT ACT OF 1987
5.59

SUBMITTED PER REQUEST OF MR. SCOTT CAMERON BY

NEVADA OUTDOOR RECREATION ASSOCIATION

April 28, 1987

Chacless Wbitson, h.

Charles S. Watson, Jr.

\section{Director}

P.O. Box 1245

Carson City, Nevada 89702

(702) 883-1169

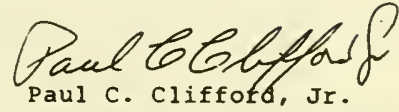

Special Consultant 2955 Berkshire Road Cleveland Heights, Ohio 44118

(216) $371-2749$ 


\section{INTRODUCTION}

The National Forests and Public Lands of Nevada Enhancement Act of 1987 deals with interchanges of responsibilities for administration of certain federally owned lands in Nevada between the Bureau of Land Management (BLM), a part of the Interior Department, and the United States Forest Service (USFS) a part of the Department of Agriculture. The Nevada Outdoor Recreation Association (NORA) believes that the transfers in question can best be thought of as three separate areas, each with different assets and management challenges. These three areas can briefly be described as:

\section{I - affected lands in the Spring Mountains in Clark and Nye Counties;}

I - affected lands east of US Highway 395 along the state line in Township $9 \& 10$ North, Range 23 East in Douglas County, and in Lyon, Mineral, and Esmeralda Counties;

III - affected lands west of US Highway 395, in Washoe county, Carson City, and all of Douglas County except applicable portions of Township $9 \& 10$ North, Range 23 East.

As we shall see throughout, this bill has the potential to assure that the scuthwest portion of Nevada, and the Las Vegas area in particular, become even better known as one of the most desirable recreation/vacation land destinations in the country for people who are not crazy about snow - even before one considers the traditional attractions of Las Vegas. Some of the time there is even snow in moderation for those who like it. The assets and resources are already there. This Bill does not - and need not - refer to a whole lot of Federal money being spent on somebodies boondoggle. All this Bill really has to do to be great is to protect and manage the assets and resources at hand. With improved and proper administration and sensible development we feel that these lands will repay the American people handsomely.

Our recommendations rely heavily on areas of critical environmental concern as a very flexible and delicate management tool to selectively protect, enhance, and ultimately develop specific identified resources for the benefit of the public. The concept of ACEC's has been endorsed by every Nevada county and so they may be expected to have strong public support.

The following suggestions for modification of Senate Bj11 59 are put forth with only the sincerest hope that the resulting Bill, as amended, can be enacted and lead directly and quickly to the best possible management of our federally owned lands in south-western Nevada. The guiding principle has been the essence of good stewardship - to preserve the resources we have, while responsibly developing the new resources we need. Some of the actions proposed may appear to break new ground, but Nevada has often been a leader in the past, and can certainly do so again. 
NORA Proposal - Senate Bill 59

SUMMARY OF CONCLUSIONS AND PROPOSED ACTIONS

AREA I

our support for the inclusion of AREA I in the Bill is predicated on the following:

1) that the Bill designate as suitable, and therefor include in the National Wilderness Preservation System, the following three BLM Wilderness Study Areas described as in the "Proposed Action Alternative" in the BLM document "Final Environmental Impact Statement Wilderness Recommendations for Clark County, Nevada, $1987 "$ :
Mount Sterling
LaMadre Mountains
Pine Creek

$$
\begin{aligned}
& (N V-050-401) \\
& (N V-050-412)
\end{aligned}
$$$$
\text { (NV-050-414); }
$$

2) that Congress defer judgement on the wilderness suitability of that portion of the BLM LaMadre WSA west of Lovell Canyon until it can be considered together with, and as a part of, the proposed wilderness area in the Mount Charleston NF Unit.

3) that Congress designate the following areas as Congressional ACEC's with boundaries as set forth in our proposed Amendments and Addenda to Map"B", and with management emphasis as follows:

Red Rock Canyon Recreation Area to be managed as a natural, scenic, and archeological area, and for public recreation;

Spring Mountains Coordinated Management Area to be managed as a natural and scenic area and for public recreation;

Wheeler Wash Joshua Tree Forest to be managed as a natural and scenic area and for public recreation with emphasis on the preservation and enhancement of the joshua tree forest;

Brownstone Canyon Archeological Area to be managed to preserve its archeological resources;

Desert View Natural Area to be managed as a natural and scenic area; 
AREA II

Our support for the inclusion of AREA II in the Bill is predicated on the following:

1) that the proposed boundary be changed to run from Nevada Highway $3 \mathrm{C}$ due east along the northern boundary of Township 8 North to the existing boundary of the Hawthorne Army Ammunition Depot, then south and east coincident with the Depot boundary, to the proposed boundary running southward from the Depot along Nevada Highway 31, thus increasing the acreage to be transferred to USFS by BLM by 82,240 acres;

2) that the proposed transfer of 14,080 acres of USFS land recommended as suitable for inclusion in the Wilderness system as part of USFS RARE II AREA $4-989$ be deleted from the Bill, and that the proposed boundary be redrawn so as to retain these areas in the National Forest System and in USFS RARE II AREA 4-989;

3) that the entire East Walker River drainage in Nevada and contained in the expanded USFS acreage as we have proposed it, be included in a Congressionally mandated ACEC to be managed principally as a natural area and for public recreation; to preserve riparian habitat, especially along the East Walker River; enhance wildlife habitat including fisheries; and preserve natural, scenic, cultural, and historic values.

A nonessential, but desirable boundary change would be to use the West walker River as the administrative boundary rather than Nevada Highway 3 west of Wellington, thus keeping BLM and USFS lands well blocked up and reducing the acreage to be transferred from BLM by 1,480 acres.

\section{AREA III}

While we strongly recommend that AREA III be deleted from the Bill, our support for. the inclusion of AREA III in the Bill would be predicated on the following:

1) expansion of the present 40 acre steamboat springs ACEC to 80 acres by adding the 40 acre BLM parcel immediately northwest of the present BLM ACEC, and creation of a Congressionally mandated ACEC for the 80 acre ACEC to be managed as a natural area and for public recreation with special emphasis on the preservation of the geysers and hot springs and continued survival of the threatened species of steamboat buckwheat, Eriogonum ovalifolium var. williamsiae;

2) creation of a Congressionally mandated ACEC for the 4040 acre Jack's Valley WMA with management emphasis on enhanced wildlife management including habitat improvement. 
SUPPORTING RATIONAL

Descriptions of the boundaries of the following areas can be found in our Proposed Amendments and Addenda to Maps "A" or "B ".

\section{AREA I: AFFECTED LANDS IN THE SPRING MOUNTAINS} (Clark and Nye Counties)

In AREA I your proposed boundary would transfer approximately 250,320 acres of BLM land to the USFS. No USFS land would be transferred to the BLM. The subject lands are well blocked up, with no administrative inholdings, and private inholdings the exception rather than the rule. Our proposal would transfer about 235,000 acres from the BLM to the USFS, and about 640 acres from the USFS to the BLM to improve management.

One of the key measures to be taken to rationalize and thereby improve management in the spring Mountains is to resolve quickly and expeditiously the issue of wilderness on lands currently administered by BLM. Potential wilderness areas exist on Forest Service administered land but are the subject of ongoing Federal legislation and need not be dealt with directly in this Bill.

There are three BLM Wilderness Study Areas in the Spring Mountains: Mount Sterling (NV-050-401), LaMadre Mountains (NV-050-412), and Pine Creek (NV-050-414). The proposed legislation would transfer all of Mount Sterling and a large portion of LaMadre Mountains WSA's from BLM to Forest Service administration and leave Pine Creek WSA which is adjacent to LaMadre with BLM administration. The northwest portion of LaMadre is also contiguous with a RARE-II proposed wilderness in the Forest Service Mount Charleston Unit. Most of the remainder of the LaMadre WSA and nearly all of the Pine Creek WSA are in the BLM designated Red Rock Canyon Recreation Area. If the WSA's are transferred to the Forest service before they are dealt with by Congress they become "orphaned" because they are administered under BLM laws executed by the Forest Service. The Forest Service RARE-II lands are already a matter of legislation in which these BLM transfers do not fit. As they will be administered by USFS, no one will want to deal with them in a BLM Bill either! The result could well be that they would exist forever in a state of 1 imbo.

This welter of contesting administrations can, however be rationally sorted out. The current BLM WSA's represent the only tracts in the area whose boundaries are defined by characteristics to be found on the ground. As such they should be the fundamental planning unit. Each of the three WSA's has a core area recommended by BLM as suitable for inclusion in the National Wilderness Preservation system. As a start to rationalization of administration, Congress should designate these recommended areas as wilderness, and thereby make them part of the formal wilderness system. Portions of the WSA's found non-suitable by 
BLM should be released from wilderness consideration, except that portion of the LaMadre WSA lying west of the recommended area, which should continue to be managed under section 603 FLPMA until Congress decides whether to include it and the contiguous National Forest RARE-II area of the Mount Charleston Unit to the north in the National Wilderness Preservation System.

The recommended portions of LaMadre and Pine Creek WSA's lie almost entirely within the very popular Red Rock Canyon Recreation Area. This recreation area is administered jointly by the State of Nevada and BLM. As a result it enjoys a somewhat higher but still meager budget than BLM acreage generally. The Red Rock Canyon Recreation Area should be enlarged slightly to the west and somewhat to the north so that it will include all of the recommended portions of the LaMadre and Pine Creek WSA's in the same administrative unit. Such expansion will also give the same administrative unit much better access to the perimeters of Red Rock and so permit much better control of public access to the recreation area. Congress should also formally recognize its unique natural, scenic, and archeological values by declaring that Red Rocks Canyon Recreation Area (including the aboriginal rock art at its southern most end) be an area of critical environmental concern.

The proposed Brownstone Canyon ACEC is of critical concern because of the unique and incredibly prolific archeological sites all along the southwest front of the LaMadre Mountains. The sites are said to be potentially some of the most important in the Southwest and should receive protection as a Congressionally mandated ACEC since the BLM has not seen fit to give them protective status in the decade of its legal requirement and mandate to do so since passage of FLPMA in 1976. Under the proposed legislation the proposed ACEC would remain entirely under the administration of the BLM.

The existing Desert View Natural Area would potentially lose the protection it currently has over those portions scheduled to be transferred from the BLM to the Forest Service. This area, while long and skinny, seeks to preserve the naturalness and scenic values of a truly unusual occurrence - a relatively short trip by automobile from the sonoran desert at the foot of Mt. Charleston to the shores of Hudson Bay at the top of the mountain, and which traverses all six life zones to be found in North America. Congressional designation of this area as an ACEC is required for two reasons. First, the BLM designation as a natural area does not necessarily make it an ACEC legally. Second, the BLM designation need not be honored by the USFS, which is free under the Bill to change land status and use to fit its planning criteria. The USFS does not have the legal prerogative to designate ACEC's nor give the some long term legal protection that they bestow. This area definitely deserves the protective status of a Congressional ACEC. 
The proposed Wheeler Wash Joshua Tree Forest Area of Critical Environmental Concern contains one of the finest stands of joshua trees remaining in federal ownership. Preservation of this large and beautiful forest while developing it for public enjoyment will require the unique set of tools supplied so well with ACEC status. Once again, the BLM has not yet acted to protect this rich resource as mandated by FLPMA. This area also richly deserves the protective status of a Congressional ACEC. This status is also particularly apt in this case because about half of the joshua tree forest is slated for transfer from the BLM to the Forest Service.

Congressional designation of the Desert View Natural Area and the Wheeler Wash Joshua Tree Forest as Congressional ACEC's could have an additional benefit, namely the development of truly coordinated management plans for the several different portions of each ACEC to be managed by either BLM or USFS. For the same reason, the Congress should create the Spring Mountains Coordinated Management Area with ACEC status to mandate the development of coordinated management plans for the entire spring Mountains area. It is only through the cooperation and especially coordination of effort by both BLM and USFS that the highest potential can be realized from these valuable public resources.

AREA II: AFFECTED LANDS ALONG THE STATE LINE EAST OF US-395 (Township $9 \& 10$ North, Range 23 East in Douglas County, and in Lyon, Mineral, and Esmeralda Counties)

In AREA II, your proposed legislation would transfer about 191,330 acres of BLM administered land to the Toiyabe National Forest and about 24,720 acres of BLM administered land to the Inyo National Forest. The BLM would receive about 14,720 acres currently administered by USFS from the Toiyabe National Forest. The subject lands are currently very well blocked up with no cross administrative inholdings, and private inholdings the distinct exception except along major roads and rivers.

Administrative encumbrances are few: 2880 acres of a Federal Agency Protective Withdrawal along the east side of Antelope valley in Douglas County, and a 450 acre Power withdrawal in Wilson Canyon on the West Fork of the Walker River.

A minor change in the proposed boundary near Wellington, in Lyon County, would aid administration. The natural boundary, which we propose be adopted as the administrative boundary, is the West Fork of the walker River rather than the road labeled as Nevada Route 3 on my map. This would continue to keep BLM and USFS acreage well blocked up and avoid an orphaned tract of USFS land on the north side of the river and separated from the remainder of USFS lands by a broad tract of private land in the valley. This would return approximately 1480 acres of the proposed transfer back tọ BLM management. 
A simple change with large acreage consequences should also be adopted. Your proposed boundary proceeds southward along Nevada Highway $3 \mathrm{C}$ until it crosses the East Fork of the Walker River. Our proposed boundary would depart from the road and proceed due east along the northern boundary of Township 8 North to the boundary of the Hawthorne Army Ammunition Depot, then south and east coincident with the Depot boundary, to your proposed boundary along Nevada Highway 31 proceeding southward from the Depot. This would greatly simplify the BLM/USFS administrative boundary and add approximately 82,240 acres to USFS holdings above that which you propose.

The Nevada portion of the East Walker River drainage south of the northern boundary of Township 8 North contains critical riparian habitat; critical summer, winter and yearlong mule deer habitat and migration routes; critical sage grouse strutting grounds and brood rearing areas; critical antelope habitat; the Aurora historic site; the historic stage route over Lucky Boy Flat, through Fletcher and on to either Aurora, or Bodie in California; and some of the most incredible natural scenery that the entire State of Nevada has to offer! We do not mean to overuse the term critical. This is the description supplied by BLM field personnel and written up in the Draft Walker Resource Management PIan and Environmental Impact Statement - Walker Resource Area (1984). The BLM itself proposed $13 \mathrm{miles}$ of the East Walker River as an ACEC. This proposed action was dropped in the Final Resource Management Plan without explanation. Senate Bill 59 has the unique opportunity to address this travesty and add reasonable protection for this critical area.

Support for the above addition, in fact for the entire AREA II portion of the proposed interchange, is predicated on recognition that it is essential that the entire East Walker River drainage contained in the expanded USFS acreage as we have proposed it, be included in a Congressionally mandated ACEC to be managed principally as a natural area and for public recreation; to preserve riparian habitat, especially along the East Walker River; enhance wildlife habitat including fisheries; and preserve natural, scenic, cultural, and historic values.

Acceptable management should NOT preclude mineral development, upgrading roads, utility corridors, regulation of water flow, hunting or fishing, or most other multiple use activities. It should preclude disposal of any further acreage in this drainage in the proposed ACEC, as it is essential to maintain public fishing access to East Walker River especially where there is reasonable current access along or from the road. Proposed significant land or visual resource disturbing activities should be scrutinized to determine necessity, and mitigating actions required where practical. Surface land use may also have to be monitored and modified if necessary to mitigate disturbance of wildife breeding, especially sage grouse. 
The proposed Bill would transfer approximately 14,720 acres currently administered by Toiyabe National Forest to the BLM. These changes seem to affect three parcels. The first is the extreme northwest corner of Township 6 North, Range 29 East where approximately 640 acres are involved. As this parcel is included in our proposed East Walker River ACEC, we do not concur that this area should return to BLM administration. If the boundary is drawn as we propose, then this adjustment becomes moot.

The second and third parcels involve USFS lands designated as suitable by USFS for inclusion in the National Wilderness Preservation System and which are part of USFS RARE II AREA 4-989 being considered in the Reid Bill deciding which areas, if any, of USFS Rare II recommended areas will in fact become part of the Wilderness System. One part, affecting about 6400 acres is in Township 5 North, Range 31 East. The other in Township 2 North, Range 32 East affects about 7680 acres. As these parcels are at this time the direct subject of another active Bill, we feel that it is inappropriate to transfer these lands at this time. Very minor changes in the proposed boundary to leave these parcels in USFS administration would remedy this problem.

Finally, there should be a Congressional mandate to the USFS that this entire AREA I I section of Toiyabe National Forest, both original and newly acquired areas, be managed with an emphasis on and sensitivity to natural areas, public recreation, and enhanced riparian and wildlife habitat.

AREA III: AFFECTED LANDS WEST OF US HIGHWAY 395

(Washoe County, Carson City, and all of Douglas County except applicable portions of Township 9 \& 10 North, Range 23 East)

In AREA III your proposed legislation would transfer administration of all existing BLM acreage to management by the USFS. No acreage would be transferred from USFS to the BLM. While the subject acreage appears to be quite large, most of the nominally affected acreage is, in fact, in private ownership. The land ownership pattern found in AREA III is almost completely opposite that found in AREA II. Approximately $2 / 3$ of the unencumbered acreage in this area (over 12,000 acres) is contained in "checkerboard" lands in Washoe County. The remaining unencumbered acreage in Carson City and Douglas County can generally be described as relatively small, isolated tracts surrounded by private land. This land ownership pattern leaves a remarkably small acreage to be transferred, as seen in Table I below. In all, the BLM only administers about 33,860 acres in Area III at the present time. Of these 33,860 acres, approximately 15,460 (about 45.78) have administrative encumbrances which could be severely adversely impacted by changes in administrative authority. 
TABLE I

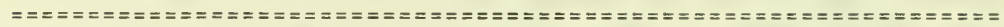

DISTRIBUT'ON OF AREA III LANDS, ADMINISTERED BY BLM BY LOCAL ADMINISTRATIVE UNIT

\begin{tabular}{|c|c|c|c|c|}
\hline Local Unit & $\begin{array}{l}\text { Total } \\
\text { Unit } \\
\text { Acres }\end{array}$ & $\begin{array}{l}\text { Unencumbered } \\
\text { Acres }\end{array}$ & \multicolumn{2}{|c|}{$\begin{array}{cl}\text { Encumbered } & \text { Type of } \\
\text { Acres } & \text { Encumbrance }\end{array}$} \\
\hline Washoe County & 12,240 & 12,200 & 40 & $\begin{array}{l}\text { Steamboat Springs } \\
\text { ACEC }\end{array}$ \\
\hline Carson City & 3,160 & 2,480 & 680 & $\begin{array}{l}\text { Federal Agency } \\
\text { Protective Withdrawal }\end{array}$ \\
\hline Douglas County & 18,460 & 3,720 & $\begin{array}{r}400 \\
3,700\end{array}$ & $\begin{array}{l}\text { Bureau of Reclamation } \\
\text { Jack's Valley Joint } \\
\text { Wildlife Management } \\
\text { Area (with Nevada } \\
\text { Dept. Of Wildlife) } \\
\text { Power Withdrawal } \\
\text { Federal Agency } \\
\text { Protective Withdrawal }\end{array}$ \\
\hline Totals & 33,860 & 18,400 & 15,460 & \\
\hline
\end{tabular}

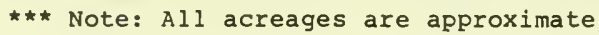

It should come as no surprise, however, that a high percentage of those lands remaining in public ownership in AREA III have unique qualities which make them highly sensitive to changes in administrative authority. The smallest encumbered unit is also perhaps the most visible to the public: 40 acre Steamboat Springs ACEC (Area of Critical Environmental Concern). This unit, while small, nevertheless has national significance since it contains the second largest collection of geysers and hot springs in Federal ownership. The only larger concentration is at Yellowstone National Park. Any scenario involving the transfer of the ACEC acreage from BLM management to control by the USFS must preserve at least the existing protective mandate for this public resource. Since the USFS has no binding authority to create or maintain ACEC's beyond local prerogative, a more permanent mechanism must be employed.

The present steamboat Springs BLM ACEC should be a Congressionally mandated $A C E C$, to be managed by the controlling agency as a natural area and for public recreation. Congress should reserve to itself the sole authority to rescind designation as an ACEC and not delegate this authority to anyone else. The proposed Congressional ACEC should also contain the 40 
acre BLM parcel immediately northwest of the present ACEC as well as the current acreage since the additional acreage also contains many of the unique features and endangered steamboat buckwheat (Eriogonum ovalifolium var. williamsiae). The area immediately east of the proposed 80 acre ACEC and extending to Us Highway 395 is also an extremely sensitive area, currently in private ownership, which should be acquired if possible. The concept of ACEC's as defined in The Federal Lands Management and Policy Act of 1976 (Public Law 94-579) has been endorsed by all Nevada counties. The proposed Steamboat springs Congressional ACEC is an impressive candidate for ACEC protection and would receive strong public support.

Additionally, private and local public interests could be impacted by the proposed interchange. Chevron, in concert with others, is developing a KGRA (Known Geothermal Resource Area) about a mile from the ACEC, part of which is on acreage proposed for transfer to the USFS. This can only add an additional layer of complexity for them in managing their development, since they will then have to deal with the USFS on all matters relating to the surface, but still deal with the BLM on all matters relating to the sub-surface. Furthermore, the BLM would still have jurisdiction over the development of the KGRA under The Geothermal Steam Act of 1970 (Public Law 91-681). Far from relieving the developers from governmental constraint, the transfer could create a nightmare for the developers in which the two federal agencies acting in their several capacities could, and very well may, demand contradictory and mutually exclusive actions of the developer, effectively precluding development.

The Nevada Department of Transportation (NDOT) has a long range program to improve US Highway 395 to freeway standards with control of access throughout its length in Nevada. A relocation of 395 between Winters Ranch and the connection to I-580 at South Virginia street in Reno has been proposed and tentatively scheduled for construction in the years 2001 to 2003. (This may seem a long way off but it is only 15 years away.) This realignment, referred to as the "S" alignment in the EIS (NDOT 1984), would follow the general alignment of the existing uS 395, between Mt. Rose Highway and Pleasant Valley along the eastern slope of steamboat Hills, approximately $3 / 4 \mathrm{mile}$ west of the existing alignment. This is in the immediate area of the steamboat Springs ACEC and the KGRA development. The proposed realignment along the entire length of US 395 would have two major effects. First, it would again introduce another federal agency into the planing process creating potential problems. second, the proposed general realignment along the entire length of US 395 would destroy the desired symmetry of having each agency control one side of the highway. Thus in a scant 15 years or less the supposed efficiencies, if they ever existed, would be lost. 


\section{8}

NORA Proposal - Senate Bill 59

Another major encumbered acreage west of US 395 is the Jack's Valley Wildlife Management Area (WMA). The WMA contains all the public land in sections 1, 2, 11, 12, 13, 14, 23, 24 in Township 14 North, Range 19 East, totalling about 4040 acres in Douglas county. The WMA is a joint management area between the BLM and the Nevada Department of Wildlife (NDOW). If this WMA is to be transferred it must again receive a level of protection which it currently enjoys and which the USFS is not in a legal position to give. Additionally, a transfer would necessitate bringing in new personnel from USFS and creating new relationships when the current relationships are quite satisfactory. A Congressionally mandated ACEC would be appropriate for this WMA so that its existence would not be subject to the whim of local administrators. The program is a valuable one and should continue.

The third large area of encumbered acreage is south of Dresslerville in southern Douglas County. Here the Bureau of Reclamation has withdrawn about 6880 acres. In the same area there is also a power withdrawal of about 400 acres. We have no idea how these withdrawals would be affected by transfer of management authority, but it should be considered.

Finally, there is also a federal agency protective withdrawal of about 3700 acres generally around Topaz Lake. This withdrawal should also remain in force if it is to be transferred to the USFS.

It would seem that inclusion of AREA III in the Interchange Bill would actually produce many more severe problems than the relatively inconsequential management problems it seeks to address. Is the on-going administrative hassle caused to the agencies themselves, the public, and local governments really justified, simply to "put more green on the map of Nevada"? Less than 35,000 or so acres, which will be excessively hard to manage effectively as National Forest Lands, is all there is to be added. We do not think it is worth the effort. It is much simpler, cost effective, and administratively sound to leave management in AREA III as it is. If AREA III is ultimately to be included in the Bill, our support would be predicated on at least Congressional ACEC protection for an expanded, 80 acre steamboat Springs ACEC and similar protection for the Jack's Valley WMA. 
PROPOSED AMENDMENTS AND ADDENDA TO THE TEXT OF SENATE BILL 59

SEC. 4. TRANSFER OF LANDS.

Sub-section (a): (page 3, line 25 and page 4, line 1)

On the assumption that our proposed boundary amendments are accepted, the acreage figures for lands to be transferred to the USFS should be revised to read: ....approximately five hundred thirty thousand acres..., and

$$
\text { (page 4, line 2) }
$$

should be revised to read: ...two maps entitled "Nevada Interchange - $A$ " and "Nevada Interchange - B" as amended and dated May 1987, ....

Sub-section (c) (page 4, Iine 22)

should be revised to read: ... approximately 640 acres.... , and

(page 4, Iine 24)

should be revised to read: ..... on a map entitled "Nevada Interchange - B".

SEC. 5. WILDERNESS SUITABILITY.

Sub-section (a) (page 6, line 6)

Should be revised to read: (a) BUREAU OF IAAND MANAGEMENT STUDY AREAS. - AnY area or portion of the Mount sterling (NV-050-401), LaMadre Mountains (NV-050-412), and Pine Creek (NV-050-414) Bureau of Land Management Wilderness Study Areas as shown on the maps referred to in section 3 (a) and designated as suitable under the "Proposed Action Alternative" of the BLM prepared document "Final Environmental Impact Statement - wilderness Recommendations for Clark County Nevada (1987)" are hereby designated as wilderness and added to the National Wilderness Preservation System pursuant to SEC. 603. of the Federal Land Policy and Management ACt of 1976 (43 U.S.C. 1712), to be managed in accordance therewith.

A new sub-section (b) should be inserted after sub-section (a):

(b) All areas or portions of the three wilderness study areas, referenced in section 5 (a) above, recommended as nonsuitable for inclusion in the National wilderness Preservation System in the environmental impact statement, referenced in section 5 (a) above, are hereby released from further wilderness consideration, except that portion of the LaMadre Wilderness Study Area (NV-050-412) situated west of the portion designated as wilderness in section 5 (a) above (and being largely west of Lovell Canyon as well) which shall be managed by the 
administering agency in accordance with the provisions of sectior 603 (c) of the Federal Land policy and Management Act of 1976

(43 U.S.C. 1782) until Congress designates that area as

wilderness or releases it from further wilderness consideration.

The current sub-sections following the inserted sub-section should have their designating letters incremented by one letter.

Sub-section (b) (page 6, line 18)

Should be revised to increase clarity to read: .... Any roadless area or portion thereof, which lies outside of a formal Bureau of Land Management Wilderness study Area, and which is made a part of the National Forest System ....

Sub-section (c) (page 7, line 14)

Should be revised to read: ....statutory direction, except that any lands to be transferred but found suitable and designated under section 5 (a) of this act shall become a part of the respective Wilderness Area and be managed in accordance with section 5 (a) of this Act.

Sub-section (d) (page 7, line 15)

Should be deleted as it is superceded by the new section 5 (a).

A new section should be inserted and titled:

SEC. 6. AREAS OF CRITICAL ENVIRONMENTAL CONCERN.

(a) The following Areas of Critical Environmental Concern as described on the maps referred to in section 3 (a) are hereby designated by Congress, which reserves solely to itself the ability to diminish or eliminate their areal extent or managerial mandate as set forth herein, and mandates the administrating agency of all or any part of an area to manage such area in accordance with SEC. 202. of the Federal Land Policy and Management ACt of 1976 (43 U.S.C. 1782) while emphasizing the resources set forth below:

Red Rock Canyon Recreation Area to be managed as a natural, scenic, and archeological area, and for public recreation;

Spring Mountains Coordinated Manegement Area to be managed as a natural and scenic area and for public recreation, with a coordinated, comprehensive management plan developed by the secretaries of Agriculture and Interior or their delegates.

Wheeler Wash Joshua Tree Forest to be managed as a natural and scenic area and for public recreation with emphasis on the preservation and enhancement of the joshua tree forest; 
Brownstone Canyon Archeological Area to be managed to preserve its archeological resources; Desert View Natural Area to be managed as a natural and scenic area;

East Walker River Natural and Scenic Area to be managed as a natural and scenic area and for public recreation; to preserve riparian habitat, especially along the East Walker River; enhance wildlife habitat including fisheries; and preserve natural, scenic, cultural, and historic values;

Steamboat Springs Geothermal Area to be managed as a natural area and for public recreation with special emphasis on the preservation of the geysers and hot springs and continued survival of the threatened species of Steamboat buckwheat, Eriogonum ovalifolium var. williamsiae;

Jack's Valley Wildlife Management Area with emphasis on enhanced wildlife management including habitat improvement.

(b) The administering agency may augment the size or purpose of an area, provided such augmentation is compatible with the original mandate for the area, through its normal planning process and such compatible additions of size or purpose shall become a part of the management mandate for the area as if they were set forth herein.

(c) Where current management plans specifically set forth certain withdrawals, exclusions, or other regulations to protect the recognized resources of a particular area designated in 6 (a) above, they shall be ratified and incorporated herein as part of the base management plan for that area.

(d) Within two (2) years from the date of approval of this Act the administering agency shall develop a management plan for each area described in section 6 (a) above in accordance with SEC. 202. of the Federal Land policy and Management Act of 1976 (43 U.S.C. 1782) which will assure the protection of the recognized resources of each area.

(e) Designation shall not of itself preclude mineral development, upgrading roads, utility corridors, regulation of water flow, hunting or fishing, or other multiple use activities but initial or developed management plans shall provide that activities detrimental to the recognized resources be scrutinized to determine valid existing rights, and mitigating actions required where indicated.

The current SEC. 6. and all subsequent sections should have their section numbers increased by 1 . 
PROPOSED AMENDMENTS AND ADDENDA TO MAP "A"

Make the following legal descriptions for language similar to them and having the same meaning) a formal part of "Map A", and amend "Map $A$ " to conform with them:

I - "The land to be transferred by BLM to the USFS shall include all BLM administered lands consisting of approximately 297,000 acres more or less and within the following meets and bounds: commencing at the intersection of the West Walker River and the Nevada/California state Line, and proceeding generally northeastward along the channel of the river to the bridge carrying Nevada Route 3 (near Wellington); then continuing generaliy northeastward along Route 3 to its intersection with Nevada Route $3 \mathrm{C}$; then generally southeastward along Route $3 \mathrm{C}$ to the northern boundary of Township 8 North (M.D.M.); then eastward along the northern boundary of Township 8 North to the existing boundary of the Hawthorne Army Ammunition Depot; then generally southward and eastward coincident with the Depot boundary to its intersection with Nevada Route 31; then generally southward along Route 31 to its intersection with the current Forest service boundary; then eastward and northward on this uSFs boundary to the eastern boundary of Range 31 East; then south along the eastern boundary of Range 31 East to the northern boundary of Township 2 North (a point coincident with the current USFS boundary); then eastward and southward coincident with the current Toiyabe FS boundary to its most eastern, yet southern point, (approximately the northern edge of Section $35 / 36$, Township 2 North, Range 32 East); then eastward on the section line to the eastern boundary of Range 33 ; then southward along the eastern boundary of Range 33, becoming coincident with and then following the existing Inyo NF boundary to the southern boundary of Township 1 South; then eastward along the southern boundary of Township 1 South to the eastern boundary of Range 34 East; then south along the eastern boundary of Range 34 East to the Nevada/California State Line; then in a northwesterly direction along the state line to the beginning point."

II - The East Walker River Area of Critical Environmental Concern shall consist of all the lands in Nevada south of the northern boundary of Township 8 North (M.D.M.) and drained by the East Walker River.

III - The Steamboat Springs Geothermal Area of Critical Environmental Concern shall consist of. $\mathrm{NE} 1 / 4, \mathrm{NW} 1 / 4, \mathrm{Sec} 33$, $\mathrm{T} 18 \mathrm{~N}, \mathrm{R} 20 \mathrm{E}$ (the current ACEC acreage) and the SW 1/4, SW 1/4, Sec $28, T 18, N, R 20$ E (M.D.M).

IV - The Jack's Valley Wildilfe Management Area of Critical Environmental Concern shall consist of all the contiguous federally owned lands in Sections 1, 2, 11, 12, 13, 14, 23, 24 , Township 14 North, Range 19 East (M.D.M.). 
Make the following legal descriptions (or language similar to them and having the same meaning) a formal part of "Map B", and amend "Map $B$ " to conform with them:

I - "The land to be transferred by BLM to the USFS shall include all BLM administered lands consisting of approximately 235,000 acres more or less and within the following meets and bounds: commencing at the northwest corner of T $17 \mathrm{~S}, \mathrm{R} 52 \mathrm{E}$ (M.D.M.) (northwest of Mt. Sterling) and continuing south along its western boundary to the northwest corner of its section 31; then about 2 miles east along the section lines to the northeast corner of section 32; then about $1 / 2$ mile south on the section line to the quarter section marker; then east about 2 miles on the half section line to the east quarter section marker of Section 34 ; then south about 1 mile on the section lines to the southwest corner of the NW 1/4, Sec 2, T 18 S, R 53 E; then east about 1 mile on the $1 / 2$ section line to the east quarter section marker of section 2; then south about $21 / 2$ miles along the section lines to the southwest corner of section 13; then east about 2 miles along the section lines to the northwest corner of Sec 19, T $18 \mathrm{~S}, \mathrm{R} 54 \mathrm{E}$; then south about $5 \mathrm{miles}$ along the section lines to the southwest corner of Sec $8, T$ T $19, R 54 E$; then east about 2 miles on the section lines to the southeast corner of Sec 9; then south about 2 miles along the section lines to the southwest corner of Sec 22; then east about 6 miles along the section lines to the southwest corner of Sec 22, T $19 \mathrm{~S}$, R $55 \mathrm{E}$; then south about 4 miles along the section lines to the southwest corner of $\operatorname{Sec} 10, T 20 \mathrm{~S}, \mathrm{R} 55 \mathrm{E}$; then about 1 mile east along the section line to the southeast corner of Sec 10 ; then about 5 miles south along the section lines to the southeast corner of Sec 2, T $21 \mathrm{~S}, \mathrm{R} 55 \mathrm{E}$; then east about 2 miles to the southeast corner of Sec 1; then south about 4 miles along the range line to the southwest corner of Sec $30, T 21 \mathrm{~S}, \mathrm{R} 56 \mathrm{E}$; then east about 1 mile along the section line to the southeast corner of Sec 30; then south about 1 mile along the section line to the southeast corner of Sec 31 ; then east about 8 miles along the township line to the southwest corner of Sec 33, T $21 \mathrm{~S}$, R $57 \mathrm{E}$; then north along the section lines about 8 miles to the northeast corner of $\operatorname{Sec} 28, T 20 \mathrm{~S}, \mathrm{R} 57 \mathrm{E}$; then west about 1 mile along the section line to the northwest corner of Sec 28 ; then north about 3 miles along the section lines to the northwest corner of Sec 9; then east about 5 miles along the section lines to the southeast corner of $\operatorname{Sec} 6, T 20 \mathrm{~S}, \mathrm{R} 58 \mathrm{E}$; then north about 7 miles along the section lines to the northeast corner of Sec $6, T 19 \mathrm{~S}, \mathrm{R} 58 \mathrm{E}$; then west about 2 miles along the township line to the southwest corner of Sec $36, \mathrm{~T} 18 \mathrm{~S}, \mathrm{R} 57 \mathrm{E}$; then north about 6 miles along the section lines to the northeast corner of Sec 2; then west about 10 miles along the township Iine to the southeast corner of $\operatorname{Sec} 36, \mathrm{~T} 17 \mathrm{~S}, \mathrm{R} 56 \mathrm{E}$; then north about 1 mile along the section line to the northeast corner of Sec 36 ; then west about 2 miles along the section lines to the 
southwest corner of Sec $25, \mathrm{~T} 17 \mathrm{~S}, \mathrm{R} 55 \mathrm{E}$; then north about 2 miles along the section lines to the northeast corner of Sec 23 ; then west about 3 miles along the section lines to the northeast corner of Sec 20; then south about 1 mile along the section line to the southeast corner of Sec 20 ; then west about 2 miles along the section lines to southwest corner of Sec 19; then north about 1 mile along the range line to the southeast corner of Sec 13 , T $17 \mathrm{~S}, \mathrm{R} 54 \mathrm{E}$; then west about 2 miles along the section lines to the southeast corner of Sec 15; then north about 1 mile along the section line to the northeast corner of Sec 15 ; then west about 1 mile along the section line to the northwest corner of Sec 15; then north about 3 miles along the section lines to the northeast corner of Sec 4 ; then west about 9 miles along the township line to the starting point.

II - The lands to be transferred from USFS to BLM administration shall consist of Section 9, Township 20 South, Range 57 East (M.D.M.) containing 640 acres more or less.

II - The Spring Mountains Cooperative Management Area of Critical Environmental Concern shall consist of all the lands, whether administered by USFS or BLM, within the following meets and bounds (exclusive of all privately owned lands, but including any currently privately owned land which may at a future time come into Federal ownership): commencing at the intersection of US Highway 95 and Nevada Highway 16 (T $16 \mathrm{~S}, \mathrm{R} 52 \mathrm{E}, \mathrm{M} . \mathrm{D} . \mathrm{M}$.$) in$ Nye County and proceeding generally southeastward along Nevada 16 to the current western boundary of Red Rock Canyon Recreation Area (BLM) in T $22 \mathrm{~S}, \mathrm{R} 58 \mathrm{E}$; then southward, eastward, and northward coincident with the Recreation Area boundary to Red Rock Front Scenic Drive (near Sec 18, T 21 S, R 59 E); then generally eastward along Red Rock Front Scenic Drive to the $59 / 60$ East Range Line; then north along the rangeline to US 95 ; then generally northwestward along us 95 to the beginning point.

IV - The Red Rock Canyon Recreation Area shall consist of all the lands currently in the parcel, plus certain additional lands, the aggregate of which shall consist of all the lands, public or private, within the following meets and bounds:

commencing on the current boundary at the southeast corner of T $22 \mathrm{~S}, \mathrm{R} 58 \mathrm{E}$ (M.D.M.) and proceeding north about $6 \mathrm{miles}$ along the range line to the northeast corner of $T 22 \mathrm{~S}, \mathrm{R} 58 \mathrm{E}$; then west about $1 \mathrm{mile}$ along the township line to the southwest corner Sec $36, T 21 \mathrm{~S}, \mathrm{R} 58 \mathrm{E}$; then north about $31 / 2 \mathrm{miles}$ on the section lines to the west quarter section marker of Sec 13 ; then east on the half-section lines about $11 / 2$ miles to the center of Sec 18, T $21 \mathrm{~S}, \mathrm{R} 58 \mathrm{E}$; then north about $1 / 2 \mathrm{mile}$ along the half-section line to the north quarter section marker of Sec 18 ; then west about $1 / 2$ mile along the half-section line to the northwest corner of Sec 18; then north about $41 / 2$ miles along the range lines to the west quarter section marker Sec 19 , T $20 \mathrm{~S}, \mathrm{R} 59 \mathrm{E}$; then east about $11 / 2 \mathrm{miles}$ (departing the current boundary at about 1 mile) along the half-section lines to the center of $\sec 20$; then north about $71 / 2 \mathrm{miles}$ along the 
half-section 1 ines to the north quarter section marker of Sec 17 , T $19 \mathrm{~S}, \mathrm{R} 59 \mathrm{E}$; then west about $61 / 2 \mathrm{miles}$ along the section lines to the northwest corner of Sec 17, T $19 \mathrm{~S}, \mathrm{R} 58 \mathrm{E}$, (a point on the proposed Forest Service boundary); then south, coincident with the proposed Forest Service boundary, about 5 miles along the section 1 ines to the southeast corner Sec 6, T 20 S, R 58 E; then west about 5 miles along the section lines to the northwest corner of Sec 9, T 20 S, R 57 E; then south about 3 miles along the section lines to the northwest corner of Sec 28 ; then east about 1 mile along the section line to the northeast corner of Sec 28; then south about 8 miles along the section lines to the southeast corner of Sec $33, \mathrm{~T} 21 \mathrm{~S}, \mathrm{R} 57 \mathrm{E}$; then departing the proposed Forest Service boundary, proceeding east about 1 mile along the section line to the southeast corner of Sec 34; then south about 3 miles along the section lines to the southwest corner of Sec 14; then east about 2 miles along the section lines to the southeast corner of Sec 13 ; then north about $1 / 2 \mathrm{mile}$ along the range line to the east quarter section marker of Sec 13, (thereby returning to the current boundary of Red Rock Canyon Recreation Area); then east about $11 / 2$ miles, coincident with the current boundary, to the center of Sec 17, T $22 \mathrm{~S}$, $R 58 \mathrm{E}$; then south about $1 / 2$ mile along the half-section line to the south quarter section marker of Sec 17; then east about $1 / 2$ mile along the section line to the southeast corner of Sec 17; then south about 3 miles along the section lines to the southwest corner of Sec 33; then east about $11 / 2$ miles along the township line to the north quarter section marker of Sec 3, T $23 \mathrm{~S}$,

$R 58 \mathrm{E}$; then south about $21 / 2$ miles along the half section 1 ines to the center of $\mathrm{Sec} 15$; then east about $1 / 2 \mathrm{mile}$ along the halfsection line to the east quarter section marker of Sec 15; then south about 1 mile along the section line to the west quarter section marker of Sec 23; then east about $1 / 2 \mathrm{mile}$ on the halfsection line to the center of Sec 23; then south about $11 / 2$ miles along the half-section lines to the south quarter section marker of Sec 26 ; then east about $11 / 2$ miles to the southeast corner of Sec 25; then north about $21 / 2 \mathrm{miles}$ along the range line to the east quarter section marker of Sec 13; then west about 1 mile along the half-section line to the west quarter section marker of $\operatorname{Sec} 13$; then north about $21 / 2 \mathrm{miles}$ along the section lines to the northwest corner of Sec 1; then east about 1 mile along the township line to the beginning point.

V - The Desert View Natural Area of Critical Environmental Concern shall consist of those lands described by the current and existing boundary as follows: commencing at the southeast corner of $T 17 \mathrm{~S}, \mathrm{R} 58 \mathrm{E}$ (M.D.M.) and proceeding north along the range line about 3 miles to the northeast corner of Sec 24 ; then west about $11 / 2 \mathrm{miles}$ along the section lines to the south quarter section marker of $\mathrm{Sec} 14$; then north about $1 / 2 \mathrm{mile}$ along the half-section line to the center of Sec 14; then west about $1 / 2$ mile along the half-section line to the west quarter section marker of Sec 14; then north about $1 / 2$ mile along the section line to the northwest corner of Sec 14; the west about 2 miles along the section lines to the northeast corner of Sec 17; then 
south about 1 mile along the section line to the southeast corner of Sec 17; then west about 1 mile to the southwest corner of Sec 17 ; then south about 1 mile to the northeast corner of Sec 30 ; then west about $1 / 2 \mathrm{mile}$ along the section line to the north quarter section marker of Sec 30 ; then south about $1 / 2 \mathrm{mile}$ along the half-section line to the center of Sec 30 ; then west about 1 mile along the half-section lines to the center of Sec 25, T $17 \mathrm{~S}, \mathrm{R} 57 \mathrm{E}$; then south about $1 / 2 \mathrm{mile}$ along the halfsection line to the south quarter section marker of Sec 25 ; then west about $1 / 2 \mathrm{mile}$ along the section line to the southwest corner of Sec 25; then south about $1 / 2 \mathrm{mile}$ along the section line to the east quarter section marker of sec 35 ; then west about $1 / 2 \mathrm{mile}$ along the half-section line to the center of Sec 35 ; then south about $1 / 2$ mile along the half-section line to the south quarter section marker of Sec 35; then west about $1 / 2$ mile along the township line to the southwest corner of Sec 35 ; then south about $1 / 2 \mathrm{mile}$ along the section line to the east quarter section marker of Sec 3, T $17 \mathrm{~S}, \mathrm{R} 57 \mathrm{E}$; then west about 1 mile along the half-section line to the west quarter section marker of Sec 3; then south about $1 / 2 \mathrm{mile}$ along the section line to the southwest corner of Sec 3; then west about $1 \mathrm{mile}$ along the section line to the northeast corner of Sec 8 ; then south about $1 / 2$ mile along the section line to the east quarter section marker of Sec 8 ; then west about 1 mile along the half-section line to the west quarter section marker of Sec 8 ; then south about 1 mile along the section lines to the east quarter section marker of Sec 18; then west about 1 mile along the half-section Iine to the west quarter section marker of Sec 18; then south about $1 / 2 \mathrm{mile}$ along the range line to the northeast corner of Sec 24, T $18 \mathrm{~S}, \mathrm{R} 56 \mathrm{E}$; then west about $1 / 2 \mathrm{mile}$ along the section line to the north quarter section marker of Sec 24 ; then south about $1 / 2 \mathrm{mile}$ along the half section line to the center of Sec 24 ; then west about $1 / 2$ mile along the half-section line to the west quarter section marker of Sec 24 ; then south about $1 / 2$ mile along the section line to the southwest corner of Sec 24; then east about 2 miles along the section lines to the southeast corner of Sec $20, T 18 \mathrm{~S}, \mathrm{R} 57 \mathrm{E}$; then north about $1 / 2 \mathrm{mile}$ along the section line to the west quarter section marker of Sec 20 ; then east about 1 mile along the half-section line to the east quarter section marker of Sec 20; then north about 1 mile along the section line to the west quarter section marker of Sec 16 ; then east about 1 mile along the half-section line to the east quarter section marker of Sec 16; then north about $1 / 2$ mile along the section line to the northeast corner of Sec 16; then east about 1 mile along the section line to the southeast corner of Sec 11; then north about $1 / 2$ mile along the section line to the west quarter section marker of Sec 11; then east about 2 miles along the half-section lines to the east quarter section marker of $\operatorname{Sec} 12$; then north about $11 / 2$ miles along the range line to the southwest corner of Sec 31, T $17 \mathrm{~S}, \mathrm{R} 58 \mathrm{E}$; then east about 1 mile along the township line to the southeast corner of Sec 31; then north about $1 / 2 \mathrm{mile}$ along the section line to the east quarter section marker of Sec 31 ; then east about $1 / 2$ mile along the half-section line to the center of Sec 32 ; then north about 
NORA Proposal - Senate Bill 59

1/2 mile along the half-section line to the north quarter section marker of Sec 32; then east about 1 mile along the section lines to the north quarter section marker of $\mathrm{Sec} 33$; then south about $1 / 2$ mile along the half-section line to the center of Sec 33 ; then east about $1 / 2 \mathrm{mile}$ along the half-section I ine to the east quarter section marker of $\mathrm{Sec} 33$; then south about $1 / 2 \mathrm{mile}$ along the section line to the southeast corner of $\mathrm{sec} 33$; then east about 3 miles along the township line to the beginning point.

VI - The Wheeler Wash Joshua Tree Forest Area of Critical Environmental Concern shall consist of all of $T 19 \mathrm{~S}, \mathrm{R} 54 \mathrm{E}$ (M.D.M.), the north half of $T 20 \mathrm{~S}, \mathrm{R} 54 \mathrm{E}$ and all the lands drained by Wheeler Wash and Wallace Canyon (a tributary of Wheeler Wash) upstream from the above tracts.

VII - The Brownstone Canyon Archeological Area of Critical Environmental Concern shall consist of that portion of the spring Mountain Cooperative Management Area south of the Kyle Canyon Road (Nevada Route 39), east of Red Rock Canyon Recreation Area, and north of Red Rock Front Scenic Drive. 
Senator Hecht. Thank you very much for coming.

Charles Callison, of Jefferson City, Missouri.

\section{STATEMENT OF CHARLES H. CALLISON, PUBLIC LANDS CONSULTANT AND NATURAL RESOURCES DEFENSE COUNCIL}

Mr. Callison. Yes. I came a distance, too, though hardly as far as our friends from Nevada.

Senator Hecht. I went to school in Columbia, Missouri.

Mr. Callison. You did? So did I, Senator.

Senator Hecht. But you've got grey hair. So I'm sure you were there many years before me.

Mr. Callison. Many years.

Senator Hecht. I was there in 1945.

Mr. Callison. I was graduated in the class of 1937.

Senator Hecht. I am from Cape Shroda, Missouri. I am well aware of Missouri.

Mr. Callison. Oh, you are. I know the Cape well.

Mr. Chairman, I have been authorized to speak for the Natural Resources Defense Council, as well as in my own behalf as an independent consultant on public land issues.

Until last November, I was Director of the Public Lands Institute, an operating division of NRDC.

Let me say in the beginning, in discussing the proposed Aerojet land exchange, that I have been on both sites, the one in Florida and the one in Nevada.

Under Section 206 of the Federal Land Policy and Management Act, the Bureau of Land Management can negotiate exchanges of public lands with other Federal agencies or with States or private owners if such trades serve the "public interest"-and this phrase is from the law.

The lands exchanged must be of equal value, as determined by appraisal, or if they are not equal, money can be exchanged to equalize the exchange, so long as the payment does not exceed 25 percent of the value of the Federal estate being divested, or traded away.

If a proposed exchange involves land in different States, then an Act of Congress is required. That is why we are here today, to consider an exchange initiated not by the Secretary of his Bureau of Land Management, but by a corporation that wants to unload 4,660 acres of land that it cannot use in Florida for 51,000 near-pristine acres in Nevada, that has a guaranteed water supply, a supply developed and proven by the U.S. Air Force with taxpayers' money when it was exploring a base site for a grandiose MX missile deployment scheme.

Congress must determine if the proposed exchange is in the public interest and not merely in the interest of the Aerojet General Corporation.

The appraisals purport to show that the 4,460 acres in Florida are worth $\$ 525$ per acre for a total of $\$ 2.4$ million, and that some of the Nevada land is worth $\$ 45$ per acre, some of it $\$ 55$ an acre, for a total of $\$ 2.3$ million. What a convenient balancing of values. Congress must decide if the appraisals are valid. I believe they are not. Frankly, I believe they were rigged. 
Aerojet's Florida land could be worth $\$ 525$ per acre only if available to the south Florida realty market for development, and, of course, it is not. Neither the State or Dade County could allow reality development there because it lies within a critical drainage basin that supplies essential fresh water for Everglades National Park. And, indeed, development is not in prospect.

Aerojet's wetlands, under the proposed deal, are destined to become the property of the South Florida Water Management District.

In Nevada, the appraiser attached no value to the availability of the proven source of water next door. This has been related, and evidence is going to be supplied by the Sierra Club spokesman, to show that last winter a nearby tract of private land, a ranch, 460 acres, land almost identical to the Coyote Springs Valley, sold for more than $\$ 500$ per acre.

Defenders of the Aerojet deal have tried to explain why a Las Vegas realtor was willing to pay ten times as much as the appraiser said BLM's land was worth. They say it was because the Butler Ranch had a water right.

Aerojet knows it can pump all the water it needs from a Nevada aquifer, utilizing the large wells already drilled by the government. It knows the allocation will be provided under the Nevada water law.

So, it is getting a steal $-51,000$ acres at $\$ 45$ or $\$ 50$ per acre-and when it stops using the area for its manufacturing purposes, or when it decides to sell off part of the tract to developers, it will net a rich windfall at taxpayers' expense.

Remember, Mr. Chairman, that public lands are property of the U.S. taxpayers, and Aerojet's very business is financed by the taxpayers through Defense Department contracts.

There are other aspects of the public interest involved in the deal. Several endangered species could be pushed over the brink by the development. Three adjacent wilderness study areas-potential additions to the National Wilderness Preservation System-also would be adversely impacts.

Details of this have been and will be provided by Mr. Watson and other witnesses.

If Aerojet would clean up its act at its plant at Rancho Cordova, it wouldn't have to move from California to Nevada, where the pollution laws are weaker and the aquifers are virgin.

The fact is Aerojet has polluted itself out of business in California, and that is why it is proposing to move to Nevada.

I have seen the draft land exchange agreement between Aerojet General and the Secretary of the Interior, through which all of the environmental problems are supposed to be mitigated or solved. It is clearly unenforceable.

It is filled with escape clauses and weasel words. Once Aerojet owns the land in fee, we shouid have no confidence that it will be carried out faithfully.

The exchange is not in the public interest. The Committee should reject it.

S. 854 deserves to be "Deep Sixed."

Mr. Chairman, let me say with respect to the other bill before us today, S. 59, that I should like to be associated with the comments 
of Mr. Watson in that respect. I think it only makes sense, since the Wilderness Study Areas and the land to be exchanged from BLM to the Forest Service have been studied intensively by the Bureau of Land Management and have been recommended, substantial parts of those areas recommended as suitable for wilderness, it only makes sense to put them in the wilderness system now.

Why have the Forest Service go through the process already performed by the Bureau of Land Management?

I hope you will consider that and will see that those provisions get into the legislation.

Senator Hechт. I would have considered it anyway. But since you are from my native Missouri, I will give it double consideration.

Mr. Callison. I thank you.

[The prepared statement of Mr. Callison follows:] 


\title{
CHARLES H. CALLISON
}

\section{Consultant}

\section{Public Lands - Environmental Issues - Organizational Structure and Procedures}

\author{
June 30 th, 1987
}

Statement of Charles H. Callison, Public Lands Consultant

To Senate Subcomittee on Public Lands, National Parks and Forests

I have been authorized to speak for the Natural Resources Defense Council, 1350 New York Avenue, N.W., Washington, D.C. 20005, as well as in my own behalf as an independent consultant on public land issues. Until last November I was director of the Public Lands Institute, an operating division of NRDC.

Under Section 206 of the Federal Land Policy and Management Act (FLPMA), the Bureau of Land Management can negotiate exchanges of public lands with other federal agencies or with states or private owners if such trades serve the "public interest." The lands exchanged must be of equal value, as determined by appraisal, or if not equal, "the values shall be equalized by the payment of money to the grantor or to the Secretary (of the Interior) $\ldots$ so long as the payment does not exceed 25 per centum of the total value of the lands or interest conveyed out of federal ownership."

If a proposed exchange involves land in different states, FLPMA goes on to say an act of Congress is required. That is why we are here today -- to consider an exchange initiated not by the Secretary or his Bureau of Land Management -- but by a corporation that wants to unload 4,660 acres of land that it can't use in Florida for 51,710 near-pristine acres in Nevada that has a guaranteed water supply -- a supply developed and proven by the U.S. Air Force with taxpayers' money when it was exploring a base site for a grandiose MX missile deployment system.

Congress must determine if the proposed exchange is in the public interest - and not merely in the interest of the Aerojet General Corporation.

The appraisals purport to show that the 4,460 acres in Florida are worth $\$ 525$ per acre, for a total of $\$ 2.4$ million, and that some of the Nevada land is worth $\$ 45$ per acre, some of it $\$ 55$ per acre, for a total of $\$ 2.3$ million. What a convenient balancing of values: Congress must decide if the appraisals are valid. I believe they are not.

Aerojet's Florida land could be worth $\$ 525$ per acre only if available to the south Florida realty market for development, and of course it is not. Neither the state or Dade County could allow realty development there because it lies within a drainage basin that supplies essential fresh water for Everglades National Park. And indeed development is not in prospect. Aerojet's wetlands, under the proposed deal, are destined to become the property of the south Florida Water Management District. 
In Nevada the appraiser attached no value to the availability of the proven source of water. Next door to the tract coveted by Aerojet, 460 acres of private land -- the same kind of desert grassland --sold last winter for more than $\$ 500$ per acre. Defenders of the Aerojet deal have tried to explain why a Las Vegas realtor was willing to pay ten times as much as the appraiser said BLM's land was worth. They say it is because the Butler Ranch had a water right.

Aerojet knows it can pump all the water it needs from a Nevada aquifer utilizing the large wells already drilled by the government. It knows the allocation will be provided under Nevada water law.

So it is getting a steal - 51 thousand acres at $\$ 45$ or $\$ 50$ per acre -- and when it stops using the area for its manufacturing purposes, or when it decides to sell off part of the tract to developers, it will net a rich windfall at taxpayers' expense.

Remember, the public lands are property of the U.S taxpayers. And Aerojet's very business is financed by the taxpayers through Defense Department contracts.

There are other aspects of the public interest involved in the deal. Several endangered species could be pushed over the brink by the Aerojet development. Three adjacent wilderness study areas -potential additions to the National Wilderness Preservation System -also would be adversely impacted.

If Aerojet would clean up its act at its plant at Rancho Cordova, it wouldn't have to move from California to Nevada where the pollution laws are weaker and the acquifers are virgin.

I have seen the draft land-exchange agreement between AerojetGeneral and the Secretary of the Interior, through which all of the environmental problems are supposed to be mitigated or solved. It is clearly unenforceable -- once Aerojet owns the land in fee.

This exchange is not in the public interest. The Committee should reject it. S. 854 deserves to be deep-sixed. 
Senator Hеснт. Congressman Bilbray, are you on a short timeframe? We have one more on this panel.

I can accommodate you now if you wish.

Mr. Bilbray. Let them go ahead if they want to. I have a short timeframe, like all of us. But let them conclude, and then I will just give my statement to you.

Senator HЕснт. Are you all right for five minutes?

Mr. Bilbray. Just fine.

Senator Hecht. Okay, then.

Well, no. Why don't you go on, Congressman. I know how it is when those bells go off. You have to go ahead and vote.

Mr. Bilbray. Well, I just voted.

Senator Hecht. Okay, then. You won't have to rush. Your prepared statement has been inserted in the record previously.

\section{STATEMENT OF HON. JAMES H. BILBRAY, A U.S. REPRESENTATIVE FROM THE STATE OF NEVADA}

Mr. Bilbray. Thank you, Mr. Chairman.

I appreciate this. I have statements to read in the record on both of the proposals, S. 59 and S. 854 .

The first testimony that I will give is on S. 854, the Nevada-Florida Land Exchange Authorization Act of 1987.

Mr. Chairman and Members of this Committee, thank you for the opportunity to enter testimony on S. 854, the Nevada-Florida Land Exchange Authorization Act of 1987.

This legislation would permit Aerojet General Corporation to acquire 54,000 acres of Bureau of Land Management Land in Clark, Lincoln, and Mineral Counties in Nevada by transferring to the Department of Interior approximately 4,800 acres of Aerojet-owned land contiguous to the Everglades.

The Department of the Interior would, in turn, sell the Florida land to the State of Florida and purchase environmentally-sensitive lands in Florida with the funds.

Aerojet General has indicated that the land located in Coyote Springs Valley is needed for the construction of a new industrial facility which would fabricate and test solid rocket motors. Approximately 43,000 acres are needed at the Coyote Springs Valley site.

As you know, Mr. Chairman, rural Nevada is sparsely populated with few lands held in private ownership. Many of these rural communities are facing difficult economic times, and because such a large percentage of the land in the county is not privately owned, development opportunities are limited.

Let me say outside of my recorded testimony is the fact that I chaired the Taxation Committee of the Nevada State Senate, and one of our major problems in our State is the fact that so little land is in private ownership, that we don't have a really stable tax base for our citizens. The more land we can get into private ownership, it is to the benefit of all of the people of the State of Nevada.

Nevada, recognizing the dire consequences of this pattern should economic hard times continue, has vigorously pursued a program of economic development and diversification. This program can only succeed if development of private lands is possible. 
I support programs which have the effect of returning as many Federally-owned lands to private Nevadans as possible.

Certainly, environmental concerns should be addressed. The presence of the proposed Coyote Springs Valley facility raises questions regarding the company's impact on water, native plants and animals, and environmentally sensitive species, such as the desert tortoise.

In addition, questions have also been aimed concerning a proposed power utility corridor through the property for future power projects.

Agencies of the State of Nevada have joined with Aerojet and Federal agencies to develop appropriate mitigations which are attached to this legislation. The Nevada Department of Wildlife and I have insisted upon various mitigation measures, which include the setting aside of 18,000 acres for a nature conservatory. In addition, provisions have been included for the installation of wildlife watering devices.

The State Department of Conservation and Natural Resources, as well as the State Water Engineer, will require permits for any water use. In addition, these agencies will closely monitor Aerojet's activities and have indicated to me that any permit for water use or waste disposal will be conditioned upon the company's compliance to the State's strict requirements.

From my tenure in the Nevada State Senate's Committee on Natural Resources, I can attest first-hand that Nevada's standards in these areas are among the most stringent in the Nation. I might add that over one-fifth of the property has been dedicated to providing a power corridor for future power needs.

$\mathrm{Mr}$. Chairman, the proposed legislation, if enacted, would not only bring jobs to Nevada, but would expand her property tax rolls.

I join the Governor of Nevada, the other Members of the Congressional delegation, the Nevada Association of Counties, the Board of County Commissioners of Clark and Lincoln Counties, the City of North Las Vegas, the Pioche Town Board, the Alamo Town Board, the Panaca Town Board, and the Caliente City Council in support of this measure.

This bill represents a sound balance between economic diversification and environmental sensitivity.

Mr. Chairman, I support environmental concerns. I think that any Member who comes here, anybody who testifies knows that I feel I am strong on environmental issues. I would be the first to condemn this project if I thought it would environmentally destroy that area of central Nevada.

I feel that we must build in the safeguards in this procedure with Aerojet. We have to work with Aerojet to make sure that some of the things, that some of these people who are testifying today are concerned about do not happen. If I thought it was going to ruin the southern part of Lincoln County and the northern part of Clark by doing some of the acts that I have been told could happen, I would be the first to stand here and oppose this bill.

I think we can (work out this problem. I think we need Aerojet to come into Southern Nevada. I think it is good for the State, it is good for the county, it is good for the people of the State, and I think we can work out our problems. 
I urge that this Committee look favorably upon this legislation.

Senator HECHT. Thank you

Mr. Bilbray. Mr. Chairman, if I may jump to the other bill, I hate to do that, but I understand you are taking testimony on S. 59 also today. Is that correct?

Senator Hecht. Yes.

Mr. Bilbray. Mr. Chairman, thank you for the opportunity to present testimony on S. 59, the National Forest and Public Lands of Nevada Enhancement Act of 1987.

I strongly support the legislation in question.

Several years ago, the Reagan Administration proposed a plan involving over 35 million acres of public lands. Under this proposal, large tracts of land under the control and management of the Forest Service would be transferred to the control and management of the Bureau of Land Management. The impact of this proposal upon Nevada would have resulted in the virtual elimination of National Forests within our area.

In response, Nevadans numbering in the thousands opposed the declassification. Joining in a concert of efforts, a broad-based coalition of conservationists, wilderness advocates, miners, ranchers, and others worked toward increasing the size of the National Forests in Nevada. In addition, each of the four largest Nevada newspapers has joined in endorsing enhanced National Forest Service Lands for Nevada.

As a result of careful negotiations between the National Forest Task Force of Nevada, the entire Nevada Congressional delegation, the Chief of the United States Forest Services, representatives of the Governor of Nevada and the Director of the Bureau of Land Management, legislation was introduced in the 99th Congress, which would have increased the size of the National Forests in Nevada.

As you may recall, Mr. Chairman, this legislation passed the House but failed to come to a vote in the Senate before adjournment.

The legislation introduced at that time would substantially ease the administrative burden of managing the lands, while simultaneously improving the administrative capacities of both the United States Forest Service and the Bureau of Land Management. In particular, the legislation would enhance the management of our land resources, including sensitive watershed areas, wildlife habitat, grazing resources, mineral resources, and increasingly valuable recreational opportunities.

The measure before this Subcommittee today is essentially the same as introduced during the last Congress. S. 59 provides over 500,000 acres of BLM land that would be added to the Toiyabe and Humboldt National Forests. These lands would be contiguous to the present Toiyabe and Humboldt National Forest holdings and are of the same character.

I serve as co-sponsor of the companion House measure, H.R. 267.

In this capacity, as co-sponsor of the companion House measure, I would like to focus attention to differences which occur between the measure as introduced in the 99th Congress and the measure before the Subcommittee today. 
The Peavine Mountain area, included in the measure of the 99th Congress, has been omitted in S. 59 and H.R. 267. I would like to take this opportunity to voice my support for restoring as nearly as possible the boundaries established in the 1986 bills.

The Peavine Mountain area is characteristic of National Forest lands and should be included in the enhancement area. Peavine Mountain intrudes into the valley and is highly visible by air and from the ground. Peavine offers important recreation for the citizens of Washoe County and represents a fragile ecosystem, balancing between the forested lands of the Sierra Nevada and the more arid desert lands found in the adjacent valley. Moreover, should Peavine not be included, only one-half of one section near the peak will be transferred from the BLM to the United States Forest Service, in contrast to our desire to alleviate administrative inefficiencies.

Secondly, water language which was struck from the 1986 Housepassed version is included in the current measures. I submit that language forwarded by the National Forest Task Force of Nevada represents a reasonable compromise. The 1987 measures should not be a forum for debating or solving complex national water rights issues, especially in light of the small amount of water on the lands affected by this legislation.

Indeed, the water involved on the lands in question is of such a small amount as to render the larger water rights moot. The citizens of Nevada should not have their lands held hostage to an issue which, by and large, is not applicable to the case at hand.

Mr. Chairman, thank you again for this opportunity and for your foresight on this issue vital to the public lands.

I would like to thank you again for taking me out of order. I was chairing a Committee on International Trafficking of Narcotics on the House side and could not get here in time. I would have liked to have heard everybody's testimony. Most of the groups have met with me. I have heard their testimony. I think we can work this thing out on both bills. I think they are both good bills and I hope that this Committee takes favorable action and quickly.

Thank you.

Senator Hecht. Thank you. We have a lot of statements, so we will give you the record when we are all finished, and you can summarize it.

Mr. Bilbray. I promise everybody that I will read them on the plane to Las Vegas. I will have plenty of time. [General laughter]

Senator Hecht. Thank you, Congressman.

Gail, I thank you for your consideration in yielding to the Congressman, but under the rules of the Senate, Congressmen and Senators have such busy schedules that we always try to accommodate them.

STATEMENT OF GAIL HARRIS, AD-HOC COMMITTEE ON AEROJET, LAS VEGAS, NV

Ms. Harris. I was pleased to defer to Representative Bilbray. He has been a friend in need in many instances on land issues in Nevada. 
I would like to speak to both bills. But first, let me introduce myself and thank you for letting me have an opportunity to be heard by this Committee.

I am a real estate broker in Las Vegas. I deal with lands and investment developments. My name is Gail Harris.

First, I would like to address the issue of the Forest Enhancement Bill, and particularly in Clark County, where, in the southern part of the State, you know the climate is hot.

We need forested lands. We need a chance to get away. Not all of us likes to go to the lakes.

The mountains in the Spring Mountain Range are one hour away, probably the best able for our citizens to accommodate their needs for mountain recreation. And the forest areas of the entire Spring Mountain Range have only a small portion of them-if I may refer to this map (indicating).

Senator Hecht. That cannot be a part of the record.

Ms. HARRIS. The Spring Mountain Range topographical map shows only a very small portion, around the Charleston Peak, in the Forest Service, whereas the entire range, from Spring Mountain to Potosi, is mountain peaks and forested areas.

The citizens of a small community of Mountain Springs were recently faced with a fire, a forest fire that burned 17,000 acres, a very fragile forest.

It was first sited in one acre of ground. The BLM decided it would be easier to just let it burn out. The wind came up, and it wasn't the easiest decision to make. But their budget is much less than that of the Forest Service.

They are only given 43 cents an acre to administer the lands, whereas the Forest Service has $\$ 2$ per acre.

The citizens of that community were very concerned. They nearly lost their homes. There was a youth camp for a church group, for the Boy Scouts, for the Girl Scouts, for the Campfire Girls. They was a Sky Mountain Ranch for recreational vehicles. All of these areas were in jeopardy.

I have here to be admitted into the record a petition from the members of the Mountain Springs Volunteer Fire Department.

Senator Hecht. It will be included in the record.

Ms. HARRIS. There are also two extra maps that I brought, which were very rapidly drawn, to include the Potosi Mountain, as well as Mt. Stirling, Mt. Charleston, and Mt. Potosi-all of this rangeinto the Spring Mountains, in the Enhancement Act.

The slow healing vegetative biome of this particular forest area is fragile, and needs the protection.

The Democratic Party of Clark County has a resolution. They wish to go on record as supporting the entire Spring Mountain Range.

[The information referred to follows:] 


\section{8}

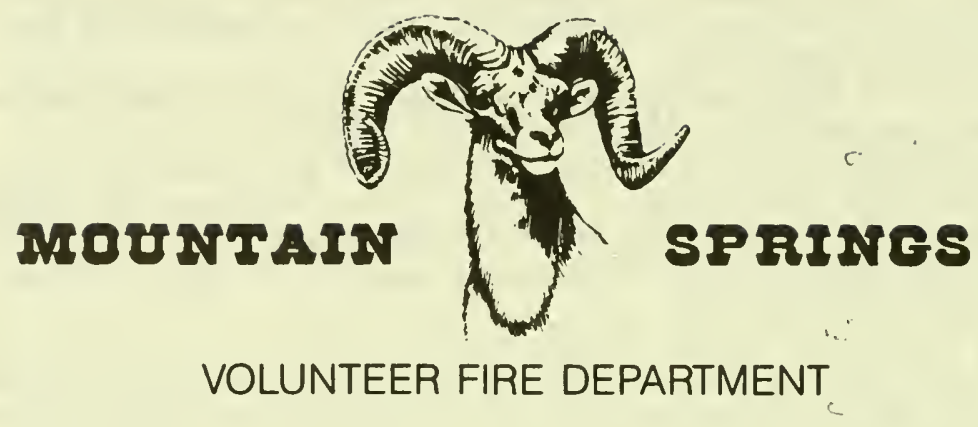

JUNE 25, 1987

TO WHOM IT MAY CONCERN:

AS CITIZENS AND RESIDENTS OF THE AREA SOUTHWEST OF LAS VEGAS, NEVADA, WHICH ENCONPASSES THE COMMUNITY OF MOUNTAIN SPRINGS, WE ARE IN FAVOR OF INCLUDING MOUNT POTOSI AS PART OF THE NATIONAL FOREST SERVICE.

WE ENCOURAGE THIS ACT IN HOPES THAT SUCH A DECISION WILL PRESERVE AND PROTECT THIS FRAGILE FOREST AREA.

\section{SINCERELY,}

THE RESIDENTS OF MOUNTAIN SPRINGS 


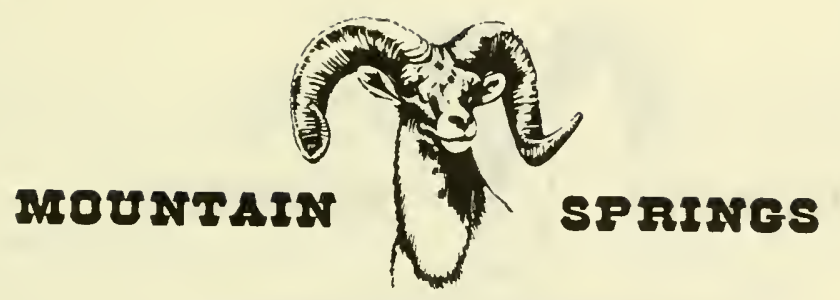

VOLUNTEER FIRE DEPARTMENT

JUNE 25, 1987

WE, THE UNDERSIGNED, ARE IN FAVOR OF INCLUDING MOUNT POTOSI IN THE NATIONAL FOREST SERVICE:

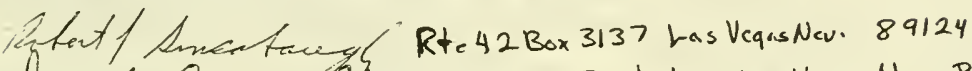
Narethy Rume Jister Box 3137 Ratc 42 Las Vras Nev. 8912 William G. Smilay Route 42 P.0. Box 3125 Las Veqas NU 8913

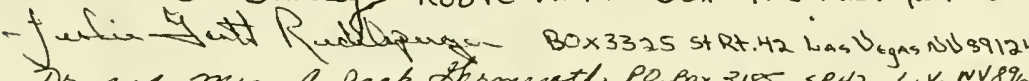

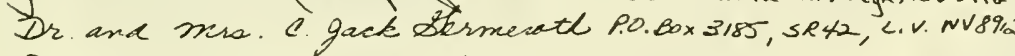

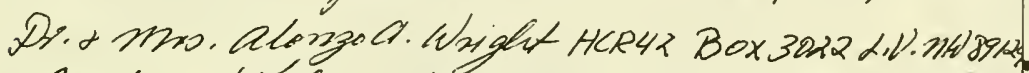

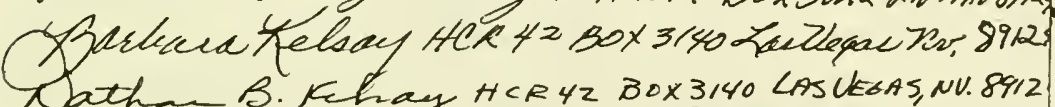
Cath B. Fefiay HCR 42 $30 \times 3140$ LAS Ck6A5, NV. 8912

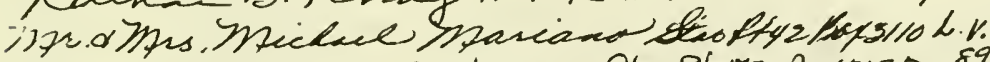

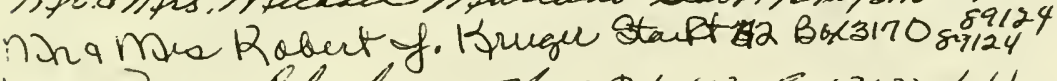

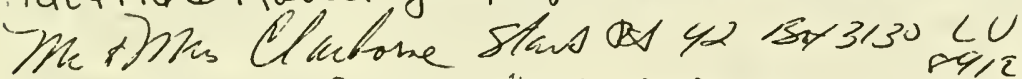

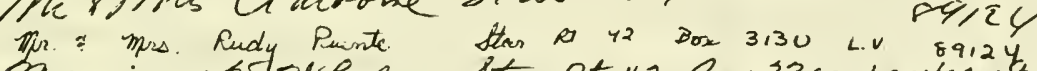

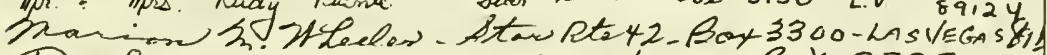

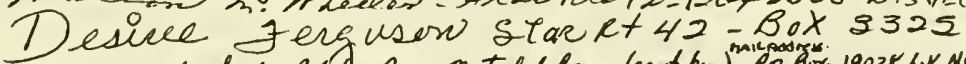

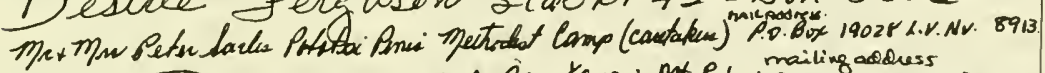

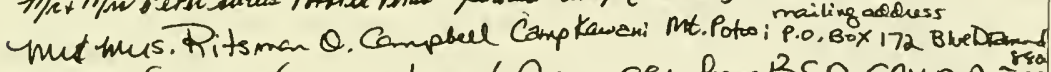
Omige Sage Comptom ( Ran get for BSA CAMP Poiros

Bus. Phone 875-4387 - Emergency / Fire 875-4189 - Star Route 42 - Box 33305 . Mpuntain Springs, NV 89124 


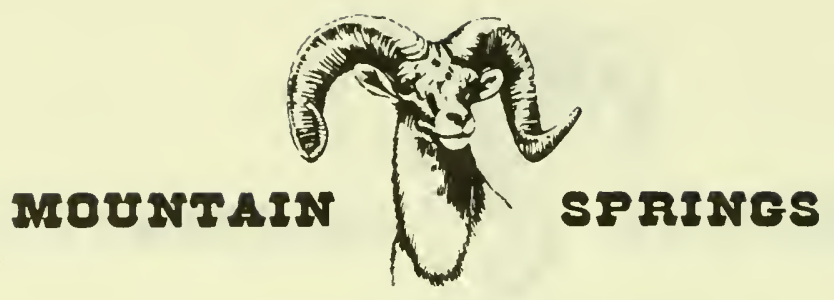

VOLUNTEER FIRE DEPARTMENT JUNE 25, 1087

WE, THE UNDERSIGNED, ARE IN FAVOR OF INCLUDIN MOUNT

POTOSI IN THE NATIONAL FOREST:

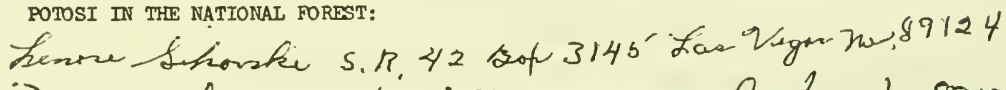

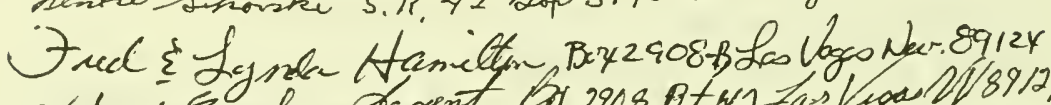

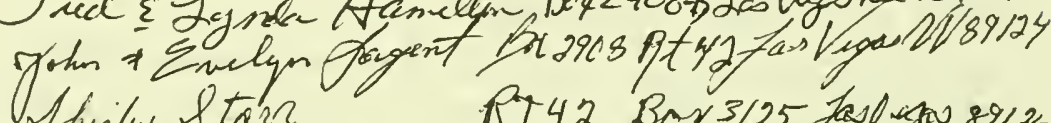
Ahinky \&tarn RT42 Bex 3125 Jas diga 89123. Pete 9 Eileer Eitckurk OT 42 or $3315 \mathrm{JV} \mathrm{V}$ Ther $7 m$. Annagly B.y 3020 ftu be 42 89724

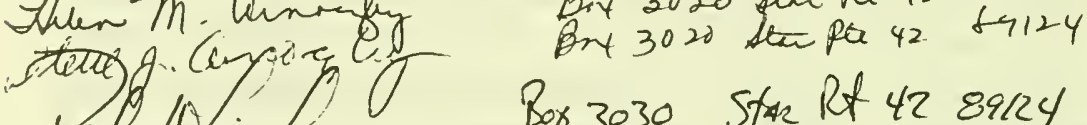

1ul Box 3030 Star Rt 4289124

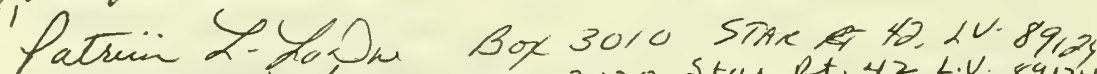

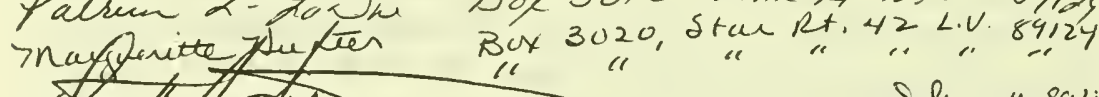

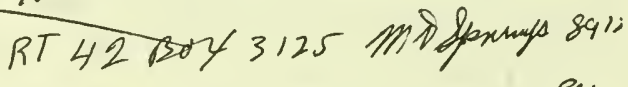
RT. $42 \operatorname{sex} 3180$ MINT. Spriallas, nel 8912 ,

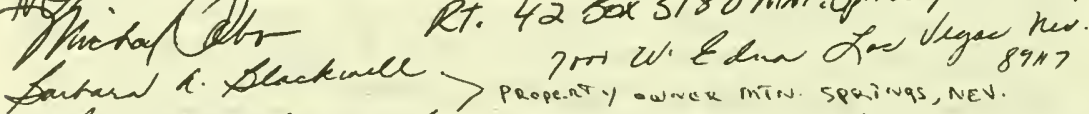

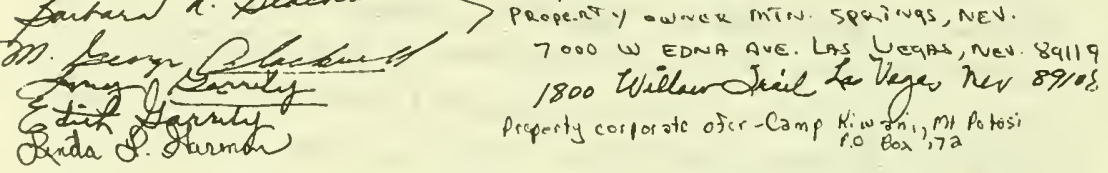

Bus. Phone 875-4387 - Emergency / Fire 875-4189 - Star Route 42 • Box 3305 - Mountain Springs, NV 89124 


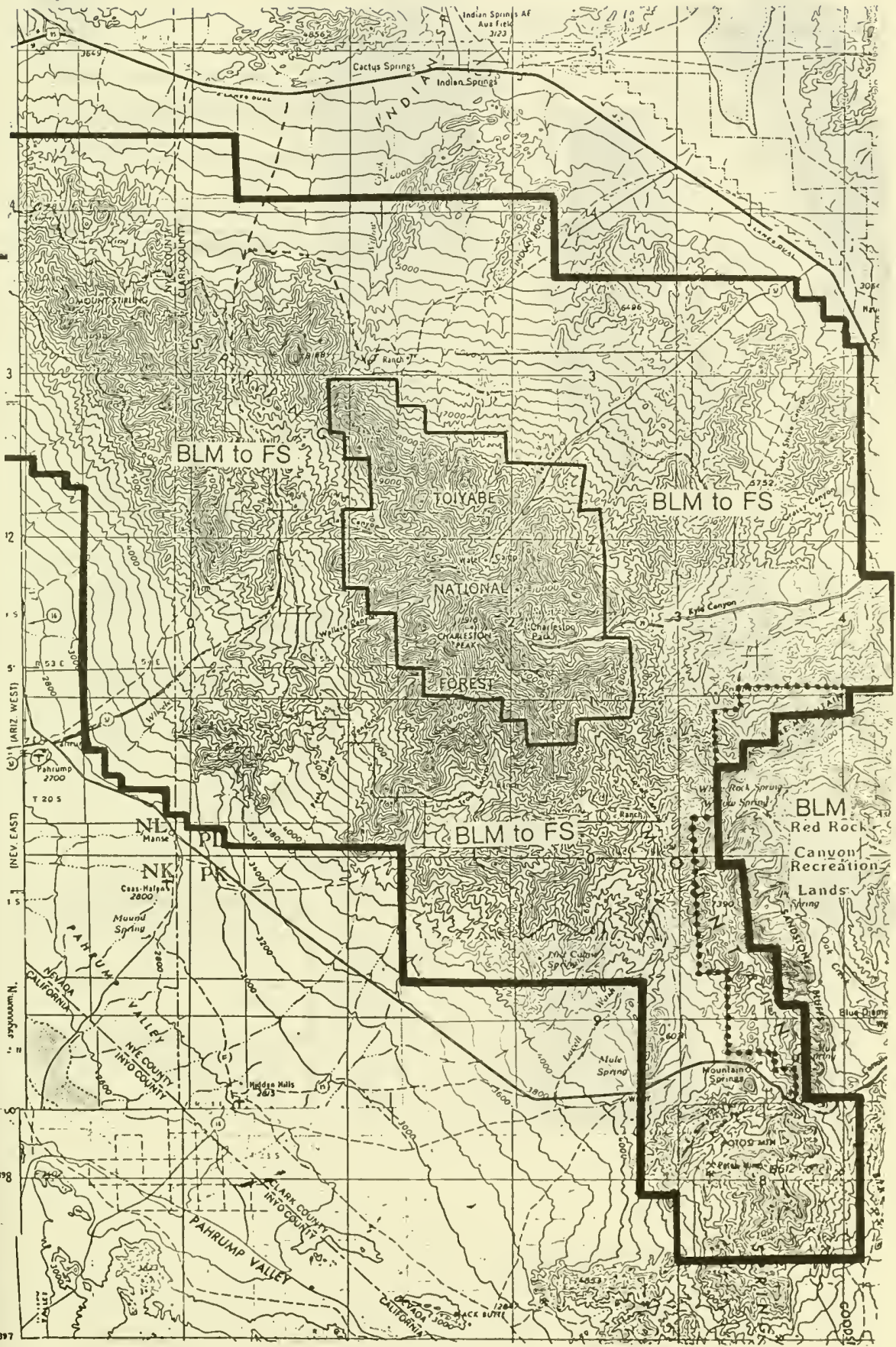




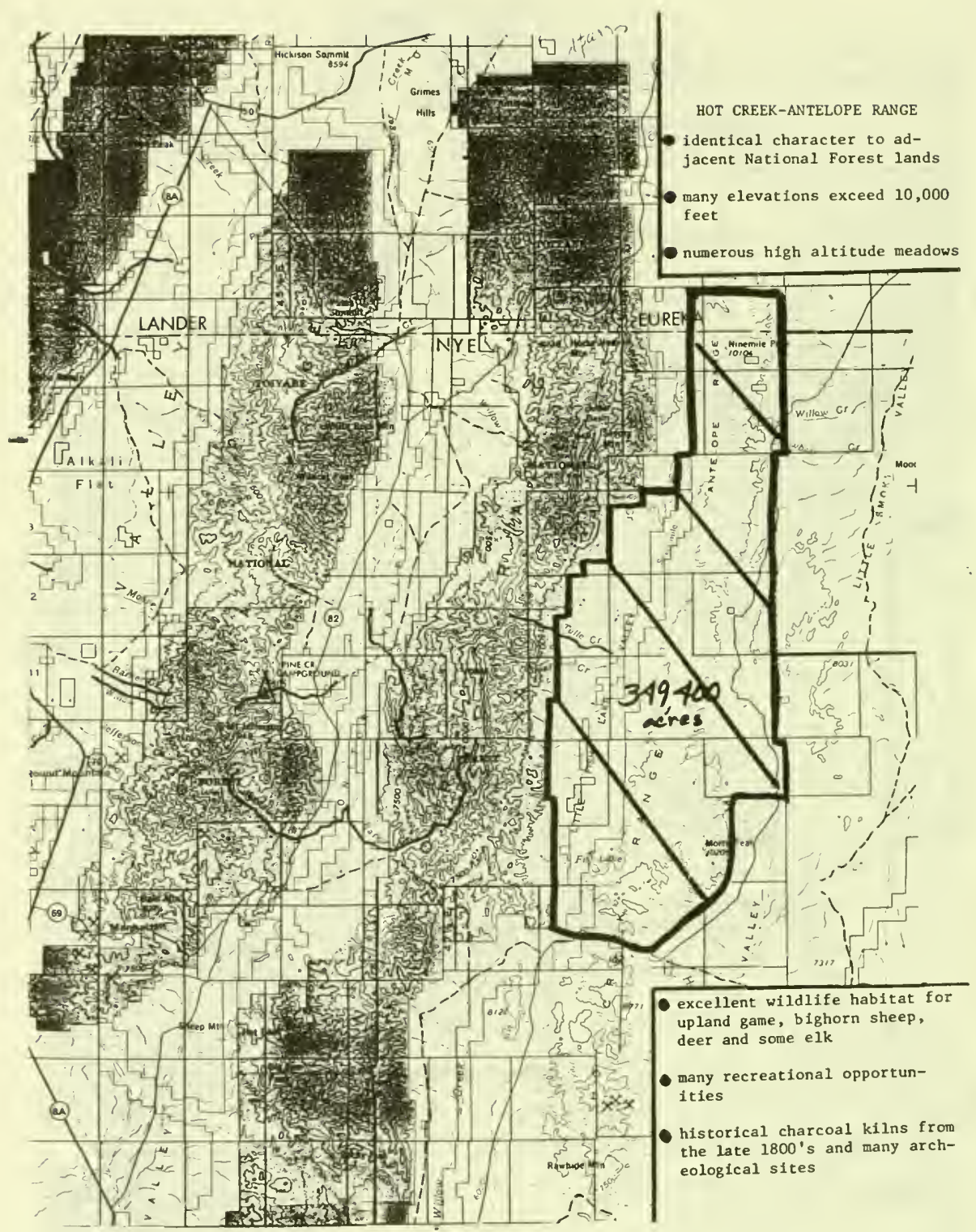



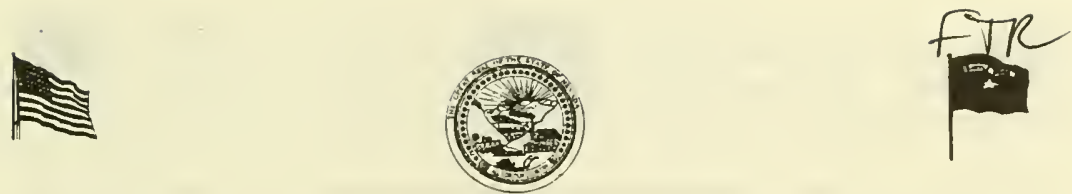

\section{LAURA KELLY SMITH CHAIRMAN}

The Democratic Party of Clark County

$$
8 \text { 고 }
$$

Committee on Energy and Natural Resources 364 SD Senate Office Bldg.

Washington, D.C. 20510

Attention: Sub Committee on Public Lands. National Parks and Forests

Dear Chairman and Sub Committee Members.

We enclose a copy of a resolution in support of Senate Bill 59 and would like this resolution made a part of the Hearing record to be held June $30,1987$.

We supported and indeed assisted the work of the National Task Force of Nevada on this issue.

\section{Sincerely,}

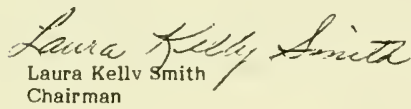

\section{LKS/ge}




\section{4}
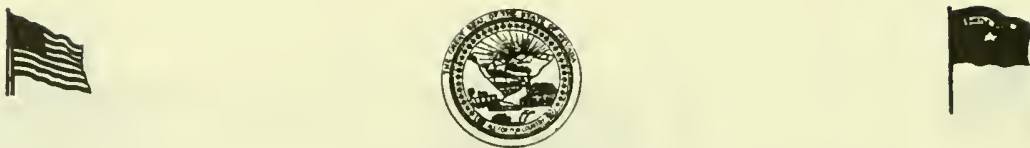

LAURA KELLY SMITH CHAIRMAN
The Democratic Party of Clark Cunnty

ग 5
GL.ORIA EDWARdS SFCRETARY

557 East Sahara. Suite 110. Lais Vegas, Nevada 89104 17021 735-1600

\section{RESOLUTION}

Whereas, in 1986, the National Forests and Public Lands of Nevada passed the U.S. House of Representatives unanimously and was on the verge of passing the U.S. Senate when the 99th Session of Congress came to an end and,

Whereas, Nevadans from all parts of the State and all walks of life have expressed support for legislation in 1986 in public hearings held in Reno, Las Vegas, and Elko and, Whereas, agreement to the Nevada proposal was reacher at a meeting in Washington D.C. on January 22, 1986 between state, local, Nevada Congressional Delegation, and officials of the Forest Service and the Bureau of Land Management.

NOW, THEREFORE, BE IT RESOlved by the Clark County Democratic Partv Central Committee that said body go on record supporting an act cited as S-59, The National Forests and Public Lands of Nevada Enhancement Act of 1987.

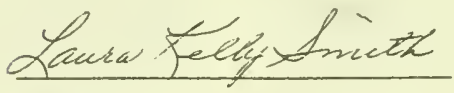

Laura Kelly Smith

Chairman 
Ms. HARRIS. I don't know what that sound is.

Senator Hecht. That's one of those things that's calling us to a vote. I can give you about five minutes and then will have to run for that vote. Then we will adjourn for about ten minutes and we'll come right back.

Ms. HARRIS. This is a document by the Forest Service which documents the groundwater resources and the springs of the Spring Mountain Range in their particular area. It is a very fragile area, and we suggest that that, along with the Hot Creek area, which is an antelope habitat-no, it is on the Antelope Range, it is an elk habitat-be added to the Forest Service and that is along the Monitor Range. A map was also included with that.

May I then progress rapidly to- -

Senator Hechт. I'll tell you, if you don't mind, I don't want to push you since you have come a long way. Why don't you let me vote and we'll take a ten minute break. I won't have to rush you, then. But I do have to vote. That is my job.

Ms. HARRIS. Oh, please vote. We appreciate your doing your job.

Senator Hеснт. We will have a ten minute recess.

[A brief recess was taken.]

Senator Неснт. The committee will come to order. Please proceed.

Ms. Harris. Basically, that I pretty well concluded my comments on the Forest Enhancement Act, except to state our concern that the wilderness study areas would be treated as national forest study areas for the wilderness, and that the water necessary to maintain and preserve the forested lands and to keep the flow of the streams would be taken care of.

And whatever water language is necessary for the western states and the national issue not be addressed in this particular issue, but that the Forest Service be given the rights and the necessary guidelines that they have always had.

The next issue of concern, of course, is the Florida-Nevada land exchange, based on an appraisal report that I find as a real estate broker to be seriously flawed. I would state that we all want to sell our land for the most possible price and buy land for the least possible price.

But Aerojet General is talking about an industrial site, every time they speak about the land in Coyote Springs. However, the appraisal carefully discussed this land as if it were nothing but marginal range land, that its highest and best use is only for range land, bad range land at that.

Now I do not see Ralph Clark in a stetson hat riding the range. I do believe he wants an industrial site. And he stated at the land hearing in Las Vegas less than two weeks ago that they had chosen the site for power, water, and access to a population center but remote enough for security.

They do have power with the power corridor. They do have access. They have two paved roads going from south to north on the east and the west boundaries. They have roads going across, at the southern end and at the northern end.

And they have water. They have the MX well, which the appraisal carefully values as if it were merely a cattle watering well, as 
worth only $\$ 10,000$. But that well is an exceptionally industrial well.

It is comparable to the well that Southwest Gas is selling 40 miles south of Lake Mead for $\$ 350,000$. It is not worth $\$ 10,000$. The land is not worth $\$ 43$ an acre. As range land, yes. As an industrial site, no.

Congress of the United States is the trustee for the owners, the people of the United States. And as such, the owe the fiduciary responsibility not to sell for less than its fair market value, or they are remiss in their responsibility as trustees.

We all know this is to be used as an industrial site. The travesty of an appraisal based as if it were worthless land, not fit for an industrial site, and so stated in the appraisal, makes a mockery of that responsibility.

We are also over the deep carbonate aquifer. That MX well was the reason that the MX was fought successfully in southern Nevada. We are an arid water-poor state, and that aquifer is a big deep aquifer, but no one knows its extent.

Now Peter Morris, the water engineer of the state, would like to stress the well to see just how much water is there. And I concur with his curiosity. But is there any assurance that Elko will not lose its water supply.

And what assurance do we have under the Transfer Act that Aerojet wants of having only a monitor once a month during business hours when they call ahead for an appointment?

We do know that a Representative from California has a welldocumented case file, Representative Matsui of California, of the Aerojet pollution of the water supply of Sacramento through an injection well that was monitored as a class one but was in reality a class four well.

What assurance do we have, and how can we protect the purity of that water? That fossil water is very pure now. Flowing out there, it is potable water.

Will there be assurance that the toxic wastes that are used, and Aerojet states in last year's testimony on the exchange bill that they wish to draw down 2 million gallons a day for their prime use.

What are they going to do with that water after it has been polluted? Will it go down into an injection well or how will they eliminate that toxic waste? We know the toxins that they have and that they plan to put into it.

But we do not know how it will be disposed of. This is a concern of the citizens of the State of Nevada who must depend on that water supply for future growth. Sixty percent of the population of the state lives in that Las Vegas valley area.

Pat Pine of the Las Vegas water district would like to tap into that aquifer. If it is polluted, it will be impossible to tap into. If it is depleted, it will be impossible to tap into.

These are concerns that an environmental impact statement should address itself with. No environmental impact statement is needed if Congress does not request it.

And we are requesting that in something of this magnitude the people of the United States be protected as to the value of the lands being given or traded, and that the people who are living in Las Vegas area and in the State of Nevada be protected for their 
water supply, for access, for mineral rights, and for the necessities of life in that state.

Thank you very much, sir.

[The prepared statement of Ms. Harris follows:] 


\section{AD HOC COMMITTEE ON AEROJET NEVADA $105 \mathrm{~Pa} 1 \mathrm{~m}$ Lane}

Las Vegas, NV 89101

June 12,1987

The Honorable Dale Bumpers, Chairman

Senate Subcommittee on Public Lands

U.S. Senate 308 Dirksen Bldg.

Washington, D.C. 20510

\section{Dear Senator Bumpers:}

We are deeply concerned about the Nevada/Florida land exchange being proposed by Aerojet General and the Department of Interior with the U.S. Fish and wildlife Service serving as the lead agency.

The proposed exchange - 51,710 acres of public land in Nevada for approximately 4,660 acres of Florida land owned by Aerojet - is now before Congress as the "Nevada-Florida Land Exchange Authorization Act of 1987," presented as identical bi11s, S.B. 854 and H.R. 1845 .

The Nevada lands involve two parcels: 8,900 acres in Garfield Flat and 42,810 acres in Coyote Springs valley. our concerns relate to the significance of the exchange to the Federal Government and to Nevada, and the impact it could have on the environmentally sensitive acreage in Coyote spring valley. We will identify the problems, as we see them, in general terms and present detailed information, photos and maps supporting these statements in separate enclosures.

(1) The appraisal of the public lands in Nevada identified for exchange is grossly under fair market value and therefore violates the value-for-value rule that the BLM is obligated to pursue in all land exchanges. We view this as an attempt to shortchange the public.

(2) The DOI and Aerojet in selecting Coyote spring Valley for a rocket assembly and testing facility picked one of the most environmentally sensitive and significant areas in southern Nevada. Such an operation would have a major impact, probably to the degree of an outright threat, to several endangered, candidate and sensitive species of wildlife, especially the desert tortoise.

(3) The handling and disposal of toxic waste has been given only superficial attention. Aerojet has said that some of the liquid waste would be sprayed on the ground after treatment. This could pose a threat to vegetation and wildlife. If any waste is injected into the ground it could contaminate the 
aquifer that supports a warm-water resort, a large dairy farm, an Indian reservation and several communities. Aerojet's long and sordid history of toxic waste mismanagement at its Sacramento plant is we 11 documented.

(4) No effort was made to identify and consider alternative sites, of which there are several in southern Nevada, that are not particularly environmentally sensitive or significant.

(5) No mitigation or compensation for Nevada's loss of these multiple-use lands has been considered or proposed except to pay for a few wildlife watering devices known as guzzlers. Indeed, an Aerojet official said "Nevada will get nothing out of it." we strongly urge Congress to stipulate that all or a major portion of the money received by the DOI from the sale of any public land in Nevada for this project be earmarked to purchase environmentally sensitive or significant private land available in the state. This then would become a part of the public domain enhancing wildlife and outdoor recreation areas open for the enjoyment of all.

(6) The details available on the evolution of the proposed exchange strongly suggest that there was collusion between the DOI and Aerojet to facilitate the exchange to assure the Environmental Report would meet the requirements for the disposal of public lands and to avoid an Environmental Impact statement and local input through public hearings. We are puzzled and believe an explanation is due congress and the public why the U.S. Fish and Wildife Service was made the lead agency and the BLM, except for the appraisal, was removed from all the procedures related to the exchange.

(7) Nevadans are losing their public lands at an alarming rate. Total military withdrawals now exceed 4 million acres and the Navy wants an additional 202,899 acres to expand bombing ranges in Churchill county. Gold mining is expanding rapidly, taking over thousands of acres. Usages based on renewing resources are being eliminated. Compounding the problem is the failure of the military to return to multiple use lands no longer used or needed, such as the 142,650 acres in the wassuk Range above Hawthorne, a prime area for deer and upland game bird hunting, camping and fishing. There is no assurance Aerojet would ever use the land. Indeed, Aerojet has said that if they do not use the land, "We will sell it. We are not in the land business." If the acreage were resold, Aerojet could reap an enormous profit and the buyer would be free to undertake development that would eliminate hunting and other outdoor recreations, as well as having a severe impact on wildife and its habitat. We suggest that whatever site is chosen that it be on a lease or buy-back basis with the DOI. 
In conclusion, we urge this subcommittee to deny favorable action on this bill and suggest it recommend the DOI be required to consider alternative sites and prepare a full Environmental Impact statement and hold scoping hearings in Las Vegas and caliente.

Sincerely,

Ad Hoc Committee on Aerojet

Members:

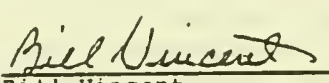

Bilvincent

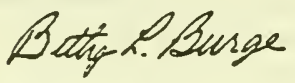

Betty Burge

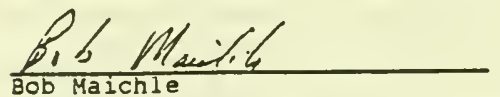

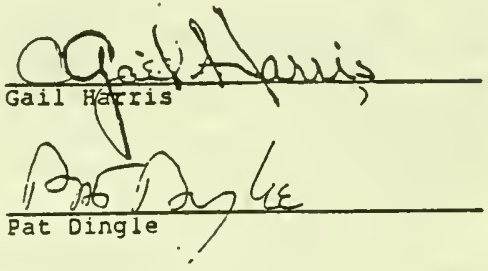

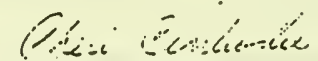

Cheri Cinkoske

P.S. Two state land advisory committees - the Nevada State Land Use Planning Advisory Council and the State Conservation Commission, in joint session as the state Multiple Use Advisory Committee on Federal Lands - adopted a resolution June 16, 1987 asking Congress to order that a full Environmental Impact statement be prepared before taking action on the Aerojet land swap proposal. The resolution said the appraisal was too low and asked that it be reviewed by an independent appraiser. The resolution also said the questions of mineral rights and access issues had not been addressed. Coyote Spring Valley is on the overthrust belt, a formation identified as having a good oil and gas potential. The resolution reinforces the suspicion that the relation of the DOI with Aerojet was not at arms-length and supports the need for an investigation by Congressional committees or the General Accounting office into all aspects of the land swap deal. 
Exhibit 1

The Appraisal

The appraisal made by the Bureau of Land Management and dated November 5, 1985 , determined the value of land in coyote Spring Valley as $\$ 45$ an acre, and that of Garfield Flat as $\$ 55$ an acre. The BLM review dated December 23, 1986, identified serious flaws in the appraisal, which will be identified in an addendum.

On November 16, 1985, 560 acres of undeveloped private land, known as the Butler Ranch, just across the state highway from Coyote spring Valley were sold for $\$ 401.79$ an acre. See attached Grant, Bargain and Sale and map.

In explaining the wide discrepancy between the appraisal of BLM land and the sale of Butler Ranch, Aerojet told Congressional groups, state legislative committees and the press that there "was a 2,200-foot lighted runway and springs of water on it" (Butler Ranch).

A dozen years ago the Butler Ranch was the site of a brothel called Sheri's. A rough landing strip for light planes was established by blading off the sparse clumps of creosote, bursage and burrobrush. A wind sock was installed on top of a 30-foot pipe. There are no lights. (See photos.) The so-called springs are no more than underground seepage - not artesian - that support some vegetation. A well which only provided enough water for domestic use was abandoned when the five brothel trailers and small adjoining building burned to the ground a number of years ago.

Aerojet further claims that the terrain of Butler Ranch differs from the rugged BLM site. However, this rugged terrain of Coyote Spring Valley provides a superior wildlife habitat to that of the Butler Ranch, thus providing a greater value to the public.

Another example highlighting the gross underevaluation is the list of BLM land sales in Lincoln and Clark Counties in 1985. Nineteen parcels totalling 166.77 acres were sold for $\$ 315,097$, an average price of just under $\$ 2,000$. A 30.38-acre industrial site in Lincoln county (see first item on the computer printout) was sold to CPC (California Portland Cement) for 514,000 or more than $\$ 450$ an acre. A Clark County 36.39-acre parcel sold for $\$ 196,500$, and 5 -acre parcels in Lincoln County went for $\$ 700$ to $\$ 1,000$ an acre. (It should be noted that coyote spring valley straddles the Clark-Lincoln County line.)

A third example of the deficient appraisal relates to the City of Mesquite. This city has applied for a public lands transfer to permit municipal expansion. A BLM appraisal has 
begun. City Manager Paul Henderson said he expected the appraisal to come in at from $\$ 300$ to $\$ 500$ an acre with the "bad lands" portion, not suitable for development, having an asking price of $\$ 100$ an acre.

Note: Garfield Flat, an isolated area with no available power, only poor access and very limited water resources received a higher appraisal (\$10 an acre more) than coyote spring Valley which has good access, a well tested at 6 cubic feet per second or 4,200 acre feet per year, and power lines running through the property. 
State panels
want studies
by Aerojet $_{\text {Jas }}$ Alu

By Mary Manning $6 / 17 / 8 \%$ i i
SUN Staff Writer

Two state land advisory committees called for Congress to order a full environmental impact' statement on Aerojet's land swap :between Nevada and Florida'Tuesday.

Although a bill has been in:" ": troduced in Congress in April to:" allow Aerojet to get $\mathbf{4 2 , 8 0 0}$ acres " in 'Coyote Springs and 8,910 acres'." in Garfield Flat near Hawthorne': for 4,650 acres of Aerojet land in: Florida, near the Everglades, both the Nevada State Land Use: Planning Council and the Statei! Multiple Use Advisory Commit-ic tee on Federal Lands approved : resolutions cailing for full EIS. studies. Since Aerojet introduced 7 the proposal through the Interior: Department, it did not need to i? conduct an EIS.

\section{Aerojet looking to Congress for land swap}

\section{Continued from Page 18}

The resolutions also call for full EIS studies for any future large project.

Both groups said Aerojet's environmental report did not address mineral rights, access to Nevada's land currentiy owned by the Bureau of Land Management, and water availability.

Bruce Tanner of Clark County's Comprehensive Planning Division said an environmental impact statement would not block Aerojet's expansion into Nevada from Sacrameato, but would help local governments with information for construction and environmental permits needed to build the rocket engine testing ground.

When asked why Aerojet came to Nevada - it is cleaning up toxic chemicals found in ground water near its facility in Sacramento, Calif. - Ralph Clark, Aerojet's project manager in $\mathrm{Ne}$ vada, replied the defense contractor wanted to attract 1,000 people to work at the facllity, access to power lines and water, roads and desolate location.

Aerojet has applied to the state engineer for a water permit for three cubic feet per second, Clark said.

If Congress approves the land swap and Aerojet builds its solid rocket fuel and testing site, 600 jobs will be available in economlcally depressed Lincoin County and 1,400 jobs become available in North Las Vegas and Las Vegas, be said.
Bill Vincent of Citizens Alert, which does not oppose Aerojet coming to Nevada, raised the is. sues of land appraisals and lack of alternate sites.

"We think they were looking for a quick answer, an easy answer, and did not look at any other sites," Vincent said.

In addition, Aerojet's appraisers settled on \$45 an acre for Coyote Springs, Vincent said. Clark noted that Aerojet hired an independent appraiser and ove taken from the Bureau of Land Managament's Ilst.

However, members of the corn. mittees sald land in Nevada rare7y went for under $\$ 300$ an acre with water, In addition, Aerojet got title to Coyote Spring's mineral rights. 


\section{Aerojet stalled on land swap}

By Chrlatopher Beell $6 / 17 / 87$
Aoview-Journal

Two state environmental committees handed Aerojet-Nevada its first significant setback Tuesday to plans for a Florida-Nevada land awap to build a solid-rocket motor assembly plant.

The two statewide advisory committees approved a resolution calling for an environmental impact statement on the project, even though federal laws do not require one and Aerojet opposes it.

The advisory committees, the state Land Use Planning Advisory Council and the atate Multiple Use Advisory Committee on Federal Lands, met all day Tuesday at the Thomas \& Mack Center to discuss various federal projects in Nevada.

Their resolution, the first govermmental opposition to Aerojet's plans for the Lincoln and Clark counties project, said a project like Aerojet' $\mathrm{B}$, which involves more than 80 square miles in Nevada, should always have a formal environmental impact statement that follows federal and state regulations.

Environmental foes of Aerojet's land swap program have argued that the environmental impact report is needed to slow the speed of the project and help a more thorough review.

Ralph Clark, general manager of Aerojet's Nevada operation, said his company believes a less formal environmental report prepared by a subcontractor for Aerojet is suffi. cient to cover any environmental concerms.

But various members of the two committees disagreed with Clark. They said concerms over access to public lands, use of water in the area, the degree of mining activity and protection of endangered apecies have not been adequately addressed by the company.

The controveryy centers on a plan that has been endorsed by all four members of Nevada's congressionnl de'egation.
To belp Aerojet develop a plant that will build solid rocket motors, officials with the U.S. Department of Interior arranged a awap of land that they hope will protect the aensitive Evergladea area of Florida.

Under the plan, which is subject to Congressional approval, about 42,800 acres in Coyote Springs Valley northeast of Las Vegas and 8,370 acres in Garfield Flats around Hawthorne would be turned over to Aerojet.

In return, Aerojet would turn Please.see AEROJET/6B

\section{Aerojet}

From 18

over to the Interior Department 4,660 scres of Florida wetlands. The department would then sell the Florida acreage to the South Forida Water Management District and use the money from the sale to buy land in a buffer zone around the wildlife refuge in the Everglades.

The members of the Nevade land use committees said Tuesday they favored the general outline of the land swap plan, commending it as a good example of economic diversification for the state.

But several members of the committees were disturbed to learn from Clark that apparently no exhaustive mineral survey of the Nevada land has been made prior to approval of the land swap.

The committee members were also concerned that plans for intense water use at the plant -2 million gallona a day - would in. crease the value of the land above the price arranged in the land swap deal.

Because of these concerns and others, the committees both voted to ask Congress to require a formal environmental impact statement.

The state Land Use Planning Advisory Council, with representa. tives from every Nevada county, added an amendment to the resolu. tion calling for an additional review of the appraisal process that led to the total acreage to be swapped in Nevada and Florida. 
Senator Hechт. Thank you very much for your indulgence with the vote. Thanks again.

Ms. HARRIS. You are welcome.

Senator Hеснт. The next panel, panel two, please come up.

Okay, we will start off with Mr. Lenard Smith, Lincoln County Commissioner from Pioche, Nevada.

\section{STATEMENT OF LENARD SMITH, COMMISSIONER, LINCOLN COUNTY, PIOCHE, NV}

Mr. Sмiтн. Thank you, Senator Hecht. It is a pleasure seeing you again.

Senator Неснт. Thank you.

Mr. Smith. I appreciate the opportunity to come here today.

I also have been a land planner for the last 35 years before I became Lincoln County Commissioner for the Soil Conservation Service, and most of it in Lincoln County. So I feel like I have had a bit of experience in this county.

I believe that this Aerojet proposal, S. 854 is one of the greatest opportunities for Lincoln County in this century, and may indeed save our county. We feel very strongly about this in the economic puddle that we are in right now.

I would like to go on with several segments of my testimony. The government without taxing authority, I and my colleagues are striving to run a government of 6.8 million acres, with a taxing authority of only about 1 percent of the area.

I ask how many governments can survive under these circumstances. This year the only way we could avoid a deficit situation was to reduce budgets of many of our departments and suspending spending last month because of a cash flow problem.

Private land and tax base is a primary ingredient to successful administration and economic growth. For economic growth, our people need jobs. And jobs, for jobs we need private land and industry.

What is a job worth? A newspaper article under the heading "Alarm" said that Nevada is getting nothing out of the Aerojet land exchange but the potential for maybe 1,000 jobs.

This statement which scoffs that jobs for people are not important is a twist of irony that their northern friends cannot comprehend. Their communities do not have a large percentage of their homes, school rooms and places of business empty.

Their children do not have to move away to find a job. A job is of course an essential part of our existence. I do not know how to measure its worth in dollars and cents, but to a family it is of great worth.

I can only tell you that from the standpoint of local government, it means less welfare, indigent, and law enforcement problems. It means a healthy society, and that is what I believe that we are all striving for.

Environment, humans, and reality. The planet we live on is being encroached by humans. Some people question and actively object to this fact of life. Rights of humans are questioned. Rights of lower forms of life are held on a pedestal and in many ways are revered in an almost fanatical frenzy. 
The frenzy causes emotionalism and turmoil and pits one way of thought against the other. The fact is that they two should work together to complement each other. Human life is precious. If it was not, why should we spend so much time and money on medical care on those who can not pay for it even.

Humans are the highest form of life created on this earth, and it was meant for them to rule over the earth and everything in it. Rule does not mean devastate or destroy. We believe that progress can be an orderly, development process in fully harmony with the sensitive environment around us.

We believe that the serious mistakes to our environment are behind us. We now have the expertise, the technical ability and laws to back this up. There is no need to stop critical progress because of those who cast aspersions, unrest, distrust, or misrepresentations.

We wonder about much of the motivations for this, and can only suspect opportunities for personal gain that goes beyond sound judgment and reasonableness.

Aerojet General is a responsible and progressive company. A year and a half or more ago I had the opportunity to visit the Aerojet plant in Sacramento with the governor of our State who was very enthusiastic about the program.

We toured the facilities, we saw the grounds, and explored with Aerojet's people the environmental problems of the past. I found that they have acted in a very responsible and diligent way to alleviate problems which occurred at their instance.

Forty million dollars worth of repentance. In some Nevada hearings I have heard a number of lies and misrepresentations of the early day Aerojet problems in Sacramento.

Regardless of the seriousness of the problem, Aerojet has acted spontaneously and progressively to alleviate the damages in every conceivable way. Their efforts have been instigated by the company without orders from the courts or any other entity.

I deeply regret such unfounded attacks and have difficulty in understanding their motivation. Aerojet has spent about $\$ 40$ million to correct the problems and will continue with much more until it is entirely right.

Biting the hands that feeds them. I witnessed in Sacramento a terrific wild flora and fauna program at the Aerojet facility. In Lincoln County, I have watched Aerojet turn every way to meet the problems and demands to make the program right.

It seems, though, that there is no solution deemed good enough short of stopping all progress in this land. We have discussed that for us to continue our way of life we must progress and grow.

We must use our land to its best and highest use. However, we see those who fight against such progress enjoying all the amenities of the affluent life that is produced by these industries. They continue to bite the hand that feeds them.

World politics is also a threat to our way of life. The only way our life can succeed is to continue to stay ahead of the enemies with our technological advances. It is only with such companies as Aerojet that we can keep out in front. 
If we lose to the communists we can forget all about our environment too. We know that they have little concern regarding such sensitive issues. We want to go on with our orderly development.

Nevada has a relatively clean environment. We cherish this, and I believe we are fortunate that the early years of this country's industrial growth bypassed Nevada when the dangers to our environment were not understood, resulting in many mistakes.

Now we have the concern, technology and the laws that will assure safety to our environment while we industrialize at this time. Most states around us do not have that advantage.

Now we can plan for and allow orderly development that is meaningful and necessary to a growing economy. We really deeply appreciate growing in this economy. I see the red light is on. I would like to say something just quickly about the outback of Nevada.

Nevada in general may be the outback of the contiguous states, but Lincoln County is the outback of Nevada. I would like to draw your attention to the map of Nevada here, showing Lincoln County in the white area.

Lincoln County is bigger than three states, New Jersey, Rhode Island and Delaware, and bigger than nine. Those three combined, but bigger than nine.

Also I would like to draw your attention to this enlarged map of Lincoln County alone. You see the little white dots there. Those little white dots are private lands. Only 1 percent of Lincoln County is private land.

These private lands of Lincoln County are like scattered islands of a great sea of public land. On islands of the sea, the people can use the resource of the sea for their needs and sustenance.

More and more, however, our people are stifled by encroaching restrictions of the bureaucracy around us, or the whim of local bureaucracy. Such laws and restrictions are placed on us by big city populations who are enamored by the wild west and manipulate us with their legislations.

We know our conditions and our plight. We need and deserve to have more voice in our life, in our livelihood, and our future.

Senator Hecht. You have got to read the next paragraph. That is the best paragraph of all.

Mr. Smith. Have you already read it? Barefoot and pregnant. Some backwoodsy ways of life have been described by the man of the family in those circumstances, bragging that they keep their womenfolk barefoot and pregnant.

More and more, our most rural counties feel that they are kept in this condition. Perhaps it is not aimed that way, but it certainly has worked out that way.

We have searched long and hard for economic survival. Every time we find an industry or a way to alleviate our problems we are knocked out of it. Thank you.

[The prepared statement of Mr. Smith follows:] 


\title{
Board of County Commissioners of Lincoln County, Nevada
}

\author{
P.O. BOX 329, PIOCHE, NEVADA 89043
}

TELEPHONE (702)962-5185

\author{
TESTIMONY OF LENARD SMTTH \\ LINCOIN COUNTY COMMISSIONER \\ CALIENTE, NEVADA \\ ON S.854 \\ BEFORE \\ SUBCOMMITIEE ON PUBLIC LANDS, NATIONAL PARKS, AND FORESTS \\ SENATE ENERGY AND NATURAL RESOURCES COMMTTIEE \\ JUNE 30, 1987
}

Mr. Chaimain and Members of the committee...

It is a great honor and rare privilege to come to this, the greatest capitol on earth, guardian of that constitution which I firmly belfeve was divinely inspired by the Almighty to lead the earth to peace and liberty.

I give my testimony today in complete sincerity of heart, knowing the plight of my people and the needs and circumstances of our area.

I believe that this Aerojet proposal is one of the greatest opportunities for Linooln county in this century, and may indeed save our county from extinction.

There are several issues to be serfously considered:

1. FEDERAL vS. PRIVATE OWNERSHIP

When Nevada was brought into the Union, it was with the agreement that it was to be on an equal footing with the other states. To make a long story short, Nevada never reallzed this goal, as you all reallze very well. We are yet dominated by $87 z$ publicly adminfstered land. Ontll the 1976 Federal Land Pollcy Act, we:were stlll operating under laws that were of the understanding that these vacant lands of Nevada were only held in a caretaker status untll such time as was right to be transferred to private or state administration. 
Testimony to the Senate Subcomittee on Public Lands, National Parks and Forests

Lenard Smith, Lincoln County, Nevada Comissionet

Page 2

The Federal Iands Policy Management Act of 1976 (FLFMA) changea that, and the land was placed under the lock and key of the Federal Govermment. It is a rare opportunity for Nevada to regain some of it's land to be used by Nevadans for the good of Nevada.

THE 'OUTBACK'

$\because$ As Nevada in general may be the outback of the contigous states Iincoln county is the OUIBACK of NEVADA. I would like to draw your attention to the map of Nevada which shows Linooln county in white, and the comparison of States SMALLER than Linooln County. Next I draw your attention to the map of Lincoln County, showing private land, which is shown by the white areas. Only slightly over $1 \%$ is private. As the parable of the Good Shepherd in St. Mathew explains, He has the ninty and nine and goes to find the one which is lost. We have the one and are searching for the ninetyISIANDS OF THE SEA nine.

These private lands of Linooln county are like scattered islands in a great sea of public land. On islands of the sea the people can use the resources of the sea for their needs and sustenance. More and more, however, our people are stifled by the encroaching restrictions of the burocracy around us or on the whim of the local burocracy. Such laws and restrictions are placed on us by big city populations who are enamoured by the 'wildwest' and manipulate us with their legislations. We know our conditions and plight. We need and deserve to have more voice in our life, livelihood and future.

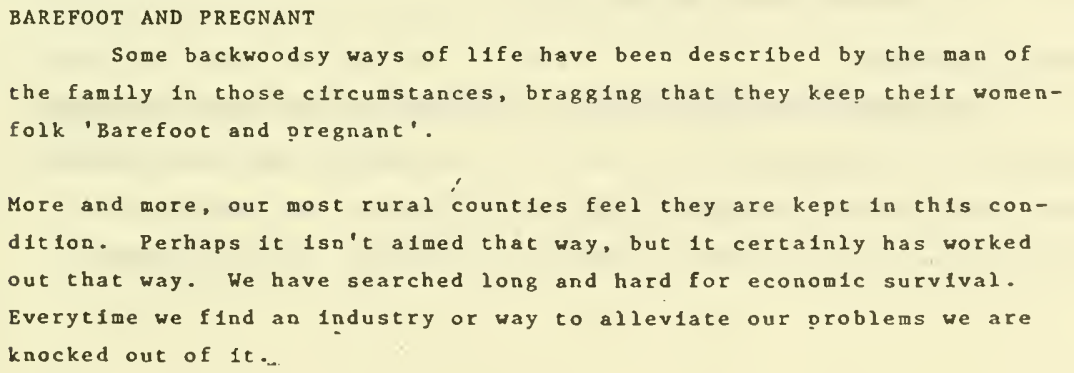




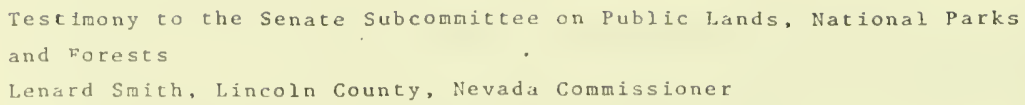

Regardless of the overwhelming odds we are working valiantly, long and hard to improve our condition. We have formed an Economic Development Task Force, led by Ms. Shelly Nadsworth, who is with me today to help explain the economics of Lincoln County.

\section{GOVERNMENT WITHOUT TAXTIG AITHORTIY}

I and my colleagues are striving to nun a government of $6,800,000$ acres with a taxing authority over anly about 18 of the area. I ask how many governments can survive under those circumstances? This year the only way we could avoid a deficit situation was to recusce budgets of many departments and spending the last month because of a cash-flow problem. Private land and a tax base is a primary ingredient to sucoessful administration and ecanomic growth. For ecanamic growth our people need jobs. For jobs we need private land and industry.

WHAT IS A JOB WORTH?

A newspaper article under the heading of "ALARM" said that "Nevada's getting nothing out of it (the Aerojet Land Exchange) but the potential for maybe a thousand jabs." This statement, which scoffs that jabs for people are not important, is a twist of irony that their northern friends cannot comprehend. Their commmities do 
Testimony to the senate Subcomittee on Public Lands, National Parks and Forests

Lenard Smith, Lincoln County, Nevada Commissioner

Page 4

not have a large percentage of their homes, schoolrooms and places of business empty. Their children don't have to move away to find a job.

A jab is, of course an essential part of our existence. I don't know how to measure its worth in dollars and cents, but to a family it is of great worth.

I can anily tell you that from the standpoint of local goverment it means less welfare indigent and law enforcement problems. It mean's a healthy society - and thats what I believe we all are striving for.

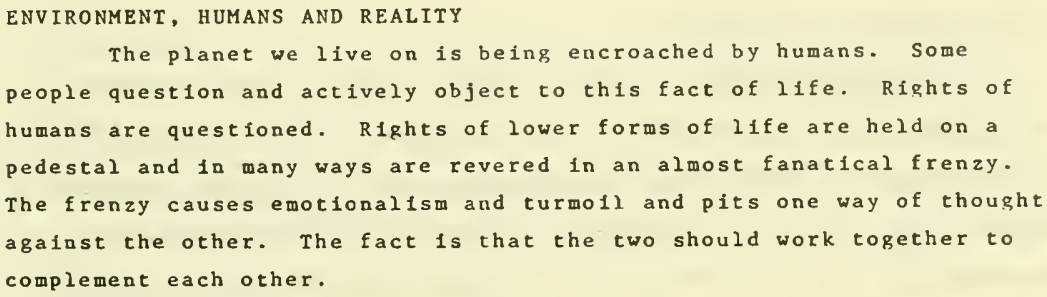

Human Iffe is precious - if it wasn't, why do we spend so much an medical care - even for those who can't pay for it? Hmans are the highest form of life created on this earth and it was meant for them to rule over the earth and everything in it. Rule doesn't mean devastate or destroy. We believe that progress can be an orderly development process in full hanmony with the sensitive enviroment around us. We believe that the serious mistakes to our enviroment are behind us. We now have the expertise, technical ability and laws to back this up. There is no need to stop critical progress because of those who cast aspersions, unrest, distrust or misrepresentations. We wonder about much of the motivation for this and can only suspect opportumities for personal gain. It goes beyond sound judgement and resonableness. 
Testimony to the senate Subcomittee on Public Lands, National Parks and Forests

Lenard Smith, Lincoln County, Nevada Commissioner

Pase 5

AEROJEI GENERAI - A RESPONSIBLE AND PROGRESSIVE COMPANY

A year and a half ago I had the opportunity to visit the Aerojet plant in Sacramento with the Governor of our state, who was very enthusastic about the program. We toured the facilities, and saw the ground and explored with Aerojet's people the $\because$ erviommental problems of the past. I found that they have acted in a very responsible and diligent way to alleviate problems which occured at their instance.

\section{\$4O MILIIONS WORIH OF REPENTENCE}

In some Nevada hearings I've heard a number of lies and misrepresentations of the early-day Aerojet problems in Sacramento. Regardless of the seriousness of the problem, Aerojet has acted spantaneously and progressively to alleviate the damages in every concievable way. Their efforts have been instigated by the ocmpary without orders from the courts or any other entity. I deeply regret such unfounded attacks and have difficulty in understanding their motivation. Aerojet has spent about 40 million to correct the problems and will contimue with much more until it is entirely right.

BITING THE HAND THAT FEEDS TMEM

I witnessed in Sacramento a terrific wild flora and fauma program at the Aerojet facility. In Iinooln county I have watched serojet tum every way to meet the problems and demands to make the program right. 'It seems though, that there is no solution deemed good enough, short of stopping all progress in this land. we have discussed that for us to contimue our way of life, we must progress and grow. We must use our land to it's best and highest use. However, we see those who fight against such progress, enjoying all the amenities of the affluent life that is producod by the industries. They continue to bite the hand that feeds them. 
Testimony to the Senate Subcomitcee on Public Lands, National Parks and Forests

Lenard Smith, Lincoln County, Nevada Commissioner

Page 6

WORLD POLTTICS

World politics is also a threat to our way of life. the only way our way of life can succeod is to continue to stay ahead of the enemies with our technological advances. It is only with such campanies as Aerojet that we can keep out in front. If we lose to the cammunists we can forget about our envirorment too! We lnow that they have little concern regarding such sensitive issues.

\section{ORDERLY DEVELOPMENT}

Nevada has a relatively clean environment. We cherish this and I believe we are fortunate that the early years of this country's industrial growth by-passed Nevada when the dangers to our environment were not understood, resulting in many mistakes. Now we have the concern, technology and the laws that will assure safety to our environment while we industrialize at this time. Most states around us do not have that advantage. Now we can plan for and allow orderly development that is meaningful and necessary to a growing economy.

We deeply appreciate living in this great country and have falth that our petitions will be heard and that decislons will be made for what is right and best for all.

Thank you. 

here.

Senator HEchт. Thank you very much for taking the trip over

Shelley, how are you?

STATEMENT OF SHELLEY WADSWORTH, EXECUTIVE SECRETARY, ECONOMIC DEVELOPMENT TASK FORCE, LINCOLN COUNTY, NV

Ms. WADSWORTH. I am very well. Thank you.

Senator Неснт. Nice to see you in Washington after seeing you in Carson City.

Ms. Wadsworth. And it is nice seeing you again. We look forward to having you back in Lincoln County.

Senator Hecht. Thank you. Next month, August.

Ms. W Adsworth. Mr. Chairman, Members of the committee, ladies and gentlemen, my name is Shelley Wadsworth, I am the executive secretary to the Lincoln County Economic Development Task Force.

It is an honor to be here in the Nation's capital to testify on behalf of the Aerojet Nevada land exchange. I am a Nevadan and I have been for 30 years.

I have grown up, lived, and worked in Lincoln County. I am biased, I know, but we have the best place in the country to live and raise our children. We have clean air, water, and a beautiful countryside. The only think we lack is jobs.

Aerojet Nevada's land exchange alone would increase our land base tax base half again. In our county, which in size is larger than nine states, we have only 1.2 percent of the land as a tax base. The rest is Federal or state owned.

The minimal tax base poses serious budget problems. If you read the Washington Post this morning, you may have seen an article regarding the crunch many local government's face because of cutbacks in revenue-sharing.

It is the history of the state and Federal government in the last few years to pass laws, rules, and regulations which increase demands on local government while the Federal government at the same time cuts revenue-sharing, reducing payment in lieu of taxes, et cetera.

The Federal government in making these demands greatly burdens local governments, in some instances forcing local governments near bankruptcy, such as our own county is. Laws, regulations, and especially court pronouncements have added 50 percent to the cost of staffing local jails.

The courts can say, because you lack five square feet to give this poor, unfortunate, humane conditions, we will soak you $\$ 1$ million. But never a word is said about where to get the money to add space to a jailhouse built over 50 years ago.

The Health Department of the United States mandates procedures for cleaning up the environment or enforcing child support, adding 20 percent to costs of the local district attorneys, but nothing but match grants are offered to offset additional costs.

Sound local governments are in a budget-busting position to come up with matching funds, yet are faced with sure court action if they do not spend money they do not have. One big help the Fed- 
eral government can offer us is to give land that industry can build on, thus broadening our tax base and providing badly needed jobs.

As I have said before, Lincoln County is 98.8 percent Federal land. As a rancher and miner's daughter, I can tell you of many battles with state and Federal agencies just in trying to carve a living from our land.

When your private land is surrounded and sometimes it is at seige by the Federal lands, you face many difficulties not encountered by other property owners in the United States. I use "at seige" because ranchers and miners and other public lands users are constantly under the gun.

Here in the east you can raise 40 cattle to the acre. You can hardly imagine an area which is considered fairly fruitful for Nevada, needing 15 acres a month to support one animal unit.

I can make this point because so many huge tracts of land are being grabbed in the West with no concern for the impact on the local people. Our lands are not as productive as the lands in the east, therefore we need much more land to simply survive.

It is unnerving to have to deal with the fact that your life and livelihood would be sacrificed, because even though you are an American, you are expendable because you lack votes, therefore political clout.

The arbitrary land grab of the Groom Mountains of 80,000 acres in the southern area negatively affected the land users there. No concern for their plight was shown. Seven ranchers and miners in the area near the national park were seriously affected by that acquisition.

The wilderness areas picked always seem to go after prime mineral deposits and grazing lands. Why? My theories are not appropriate here. But I am gravely concerned for rural Nevada.

We not only face losing our access to the lands that support us, but we also face the constant threat of the state park system condemnation proceedings, because our family ranch of over 100 years would be a nice addition to a huge, largely unused park system in Lincoln County. We are in double jeopardy, and that is supposed to be unconstitutional.

Rural Nevadans face economic hard times. We have been in decline for 20 years and when we think we have reached the lowest point, we find that there are lower points. Ranching, mining and the railroad once were booming industries in our county.

Now, within five years, all three are all but gone. Agricultural lands are out of production. Only 10 percent are producing and they all face bankruptcy. All mines are shut down and the railroad pulled out.

Lincoln County faces extinction in a very real sense of the word. Our organization was once the Economic Survival Task Force. It was named so because of the severe economic hard times we faced and were in and because of the determination we have to survive.

The sad fact is, though, all the determination in the world cannot save a dying county without government help instead of hindrance. Land values in Lincoln County have dropped 50 percent in 10 years.

You will find the land value analysis done by a master appraiser at financial designs. You will note the drop of land values of 11 
percent overall since 1985 . Pioche and Alamo experienced minimal growth because low income retired people are moving in more and more.

The current total assessed value of the country is $\$ 46$ million, down from $\$ 49$ million over a year ago. Aerojet's land exchange would increase our county's acreage by half again.

Once the project is complete, our tax base could triple and then some. Our county assessor stressed that these are low figures. He estimates the project could improve our net worth to $\$ 205$ million. This does not include all the new housing, sister industry, and growth of local businesses in our communities.

Can you imagine the impact of increasing our budget 2.5 times? A county which was forced to go to our state legislature to ask for $\$ 600,000$ to allow our local government to exist.

Our land values are dropping. I lived and worked on a ranch in the northern half of the county, which is now bankrupt. This place has been for sale for four years going on five.

The asking price four years ago was $\$ 4.5$ million. Today it is going for over $\$ 2.5$ million. Two million dollars cash would buy you a ranch with 1,300,000 acres of public grazing, 9,000 acres in private land, over 30 livestock and irrigation wells, over 100 natural springs, three hot springs, three reservoirs, four sets of apartments, 10 homes, a huge shop, numerous corrals, a 1,000 head capacity feed lot, an outdoor and indoor arena, stables for horses, and a beautiful natural pasture at headquarters.

All in a beautiful high desert setting, with Mount Wheeler to the north, and all for $\$ 54$ an acre. A beautiful place with improvements, water, fishing, hunting, and all for $\$ 54$ an acre?

My first thought when I asked the asking price for Aerojet's Coyote Springs land was that they were overcharged. The conservation district gives land ratings by agricultural value on a scale of one to eight, one being the very best.

Coyote Springs is a very low eight. The soil is skeletal and acres of water would not make it suddenly fertile again. The acreage is desolate. The Federal Land Bank estimates land values in the West by how many head of stock can be supported by a tract of land.

The highest rate given is $\$ 1,000$ per head. Geyser, with all its beauty and water and forage, can support 4,000 head of cattle. It should be worth more than $\$ 2$ million, at the lowest at least $\$ 250$ an acre, and it goes for $\$ 54$ an acre.

The Aerojet land can support 40 head of cattle for only 30 days every four to 10 years, making it worth less than $\$ 3,40030$ days every four to 10 years. The BLM says that this land is rarely used because it rarely has forage that lasts any longer than 30 days.

The highest possible use for Coyote Springs is what Aerojet proposes. The good to Nevada and Lincoln County is immeasurable. It is funny that the Federal Land Bank charges $\$ 1,000$ per animal unit while the Federal government charges $\$ 60,000$ per animal unit. I wish Geyser could sell so well.

Coyote Springs Valley is north of Las Vegas, 57 miles in the middle of a vast rubble desert. The plant life is hostile and wildlife is minimal. I feel secure in my concerns for the environment, that Aerojet is a responsible and effective addition to the environment. 
I think the champions of the tortoise grossly underestimate the adaptability of the tortoise and its intelligence and ability to survive.

Do you realize that only 2 percent of the endangered and extinct animals became so in the last few thousand years? The other 98 percent became extinct before man was on earth.

Aerojet will protect and preserve the wildlife while enhancing their environment. In rural Nevada the small town, isolated from the mainstream U.S., faces a slow and sure extinction.

It would be a terrible loss to Americana if all rural American fades to ghost towns because human quality of life took a back seat to reptile lifestyle.

We are forced to raise our children to look to the city for employment because at present no jobs with a future exist. Our unemployment rate looks deceptively low because when a person loses their job they move.

They nothing exists to replace the lost jobs. Lincoln County lost 318 residents last year. This is a population of 4,000 people. Business licenses in one town are down over 30 percent this year.

Our own state legislature denied us one safe clean industry this year. I hope my Congress will not deny us Aerojet as well. We are proud. We want to help ourselves by economic diversification. But we need your help.

I strongly urge you to pass the Aerojet land exchange. The addition to our tax base alone could help relieve the severe budget deficit in our local government and open the doors to a strong economy.

Thank you.

[The prepared statement of Ms. Wadsworth follows:] 


\section{TESTIMONY OF SHELLEY WADSWORTH}

EXECUTIVE SECRETARY, ECONOMIC DEVELOPMENT TASK FORCE LINCOLN COUNTY, NEVADA

ON S.854

BEFORE

SUBCOMMITTEE ON PUBLIC LANDS, NATIONAL PARKS, AND FORESTS SENATE ENERGY AND NATURAL RESOURCES COMMITTEE

JUNE 30,1987

Mr. Chairman, Members of the Committee, Ladies and Gentlemen-my name is Shelley Wadsworth. I am the Executive Secretary to Lincoln County's Economic Development Task Force.

It is an honor to be here in the Nation's Capital to testify on behalf of the Aerojet Nevada Land Exchange.

I am a Nevadan and have been so for 30 years. I have grown up, lived and worked in Lincoln county. I'm biased I know, but we have the best place in the country to live and raise our children. We have clean air, water and a beautiful countryside-the only thing we lack is jobs.

Aerojet Nevada's Land Exchange alone would increase our land tax base $1 / 2$ again. In our county, which in size is larger than nine states, we only have 1.28 of the land as a tax base. The rest is Federal or state owned. The minimal tax base poses serious budget problems. If you read the Washington Post this morning, you may have seen an article regarding the crunch many local governments face because of cutbacks on revenue sharing.

It is the history of State and Federal Government the last few years to pass laws, rules and regulations which increase demands on local government, while the Federal Government at the same time, cuts revenue sharing, reducing payment in lieu of taxes, etc.

The Federal Government in making these demands, greatly burdens local governments, in some instances forcing local government near bankruptcy, such as our county is.

Laws, regulations and especially court prouncements have added $50 \%$ to the costs of staffing local jails. The courts can say "Because you lack 5 square feet to give this poor unfortunate humane conditions, we'll soak you \$l Million dollars!" But never a word is said about where to get the money to add the space to a jail-house built over 50 years ago!

The Health Department of the United States mandates procedures for cleaning up the environment or enforcing 
child support adding 208 to costs of local Distric Attorneys but nothing but match grants are offered to offset additional costs. Sound local governments are in a budget busting position to come up with matching funds yet are faced with sure court action if they don't spend this money they simply don't have!

one big help the Federal Government can offer is to give land that industry can build on, thus broadening our tax base and providing badly needed jobs.

$\ddot{A}$ S I have said before, Lincoln county is $98.8 \%$ Federal land. As a rancher and miner's daughter. I could tell you of many? battles with state and federal agencies just in trying to carve a living from our land. When your private land is surrounded and sometime at siege by the Federal lands, you face many difficulties not encountered by other property owners in the United State.

I use "at siege" because ranchers and miners and other public lands users are constantly under the gun. Here, in the East where you can raise 40 cattle to the acre, you can hardly imagine an area which is considered fairly fruitful for Nevada--needing 15 acres a month to support 1 head of cattle. I make this point because so many huge tracts of land are being grabbed in the west with no concern for the impact on the local people! Our lands are not as productive as the lands in the East, therefore, we need much more land to simply survive! It is unnerving to have to deal with the fact that your life and livelihood are to be sacrificed because even though you are American, you are expendable because you lack votes, therefore political clout. The arbitrary land grab of the Groom Mountains of 80,000 acres in the southern area negatively affected the land users there; no concern for their plight was shown. Seven ranchers and miners in the area near the National Park are seriously affected by that acquisition. The wilderness areas picked always seem to go after prime mineral deposits and grazing lands-why? My theories are not appropriate here, but I am gravely concerned for rural Nevada. We not only face losing our access to the lands that support us, but we also face constant threat of the state park system coming after the minimal local private lands through condemnation proceedings, because our family ranch of over 100 years would be a nice addition to a huge, largely unused park system in Lincoln County.

We are in double jeopardy! And that is supposed to unconstitutional!

Rural Nevadans face economic hard times. We've been in decline for 20 years. When we think we've reached the lowest point we find there are lower ones. Ranching, mining 
and the railroad once were booming industries in the county. Now within 5 years all 3 are all but gone.

Agricultural lands are out of production. Only $10 \%$ are producing and they all face bankrupcy. All mines are shut down and the railroad pulled out. Lincoln County faces extinction in a very real sense of the word.

Our organization was once the Economic Survival Task Force. It was named so because of the severe economic hard times we were in and because of the determination we have to servive.

The sad fact is though all the determination in the world ; cannot save a dying county without government help instead of hindrance.

Land values in Lincoln County have dropped 508 in 10 years. You will find a land value analysis done by a master appraiser at $F$ inancial Designs. You will note the drop of land values of 118 overall since 1985. Pioche and Alamo experienced mimimal growth because low income retired people are moving in more and more.

The current total assessed value of the county is 46 million--down from our 49 million a year ago. Aerojet's Land Exchange would increase our county's acreage 1/2 again. Once the projects are complete our tax base could triple and then some!

Our County Assessor, Bill Lloyd, stressed that these are low figures. He estimates the project could improve our net worth to 205 million dollars. This doesn't include all the new housing, sister industry and growth of local business in our communities.

Can you imagine the impact of increasing our budget $21 / 2$ times? A county which was forced to go to our state legislature to ask for $\$ 600,000$ to allow our local government to continue to exist!

Our land values are dropping--I lived and worked on a ranch in the Northern half of the county which is now bankrupt. This place has been for sale for 4 years, going on 5 . The asking price 4 years ago was 4.5 million dollars. Today, it is going for 2.5 million dollars. Two million cash would buy you a ranch with $1,333,230$ acres public grazing, 9,212 acres in private land, over 30 livestock and irrigation wells, over 100 natural spings, 3 hot springs, 3 reservoirs, 4 sets of apartments, 10 homes, a huge shop, numerous corrals, a 1000 head capacity feedlot, an outdoor and indoor arena, stables for horses, and beautiful natural pastures at headquarters--all in a beautiful high desert setting with Mount Wheeler to the North, and all for $\$ 54$ an acre. 
A beautiful place with improvements, water, fishing, hunting, and all for $\$ 54$ an acre. My first thought when I heard the asking price for Aerojet's Coyote springs land was they were over-charged!

The conservation district gives land ratings by agricultural value on a scale of $1-8--1$ being best. Coyote springs valley is a low 8 . The soil is skeletal and acres of water would not make it suddenly fertile.

This acreage is desolate!

The Federal Land Bank estimates land values in the West by how many head of stock can be supported by the tract of land. The highest rate given is $\$ 1000$ per head. Geyser-with all it's beauty and water and forage--can support 4,000 head of cattle. It should be worth even more than 2 miliion dollars, lowest at least $\$ 250$ dollars an acre and it goes for $\$ 54$.

The Aerojet land can support 40 head of cattle for only 30 days every 4-10 years, making it worth less than 40,000 for 30 days every 4-10 years. The BLM says rarely is it used because rarely is there forage and that lasts no longer than 30 days.

The highest possible use for coyote springs is what Aerojet proposes. The good to Nevada and Lincoln County is immeasureable. It is funny that Federal Land Bank charges $\$ 1000$ per head of cattle, while the Federal Government charges $\$ 60,000$ a head. I wish Geyser could net so well!

Coyote springs Valley is North of Las Vegas--57 miles in the middle of a vast rubble desert. The plant life is hostile and wildlife minimal.

I feel secure in my concerns for the environment that Aerojet is a responsible and effective addition to the environment. I think the champion of the tortoise grossly underestimates the adaptability of the tortoise and it's intelligence and ability to survive.

Do you realize that only $2 \%$ of the endangered and extinct animals bacame so in the last few thousand years?

Aerojet will protect and preserve the wildlife while enhancing their environment.

In rural Nevada the small town, isolated from mainstream U.S.A., faces slow and sure extinction. It would be a terrible loss to America if all rural America fades to ghost towns because human quality of life took a back seat to reptile lifestyle. 
We are forced to raise our children to look to the city for employment because at present no jobs with a future exist. our unemployment rate looks desceptively low because when a person loses their job, they move. They know nothing exists to replace the lost job. Lincoln county lost 318 residents last year. Business lincenses in one town were down $30 \%$ this year.

Our own state Legislature denied us one safe, clean industry this year. I hope my Congress won't deny us Aerojet as well.

We are proud. We want to help ourselves by economic diversification, but we need your help. I strongly urge you to pass the Aerojet Land Exchange. The addition to our tax rolls alone would help relive a severe budget deficit in our local government and opens the doors to a strong economy.

Thank you for your time. 
:H 1 SER RANCH

$1,333,216$ Acres

30 Irrigation Wells

100 Springs

3 Culinary wells -

Supports 3,000 head mother cows year-round

\section{Apartments}

10 Homes

1 Mechanic's Shop

10 Corrals

1 Indoor Arena and Stable

2 Natural hot Springs

2,000 Acres Natural Pastures

Asking Price $\$ 54.00$ per acre
COYOTE SPRING IALLEY

45,000 icres

None

None

one

Supports Less than 50 Cattle 1 month every $4-10$ years

None

None

None

None

None

None

None

Asking Price $\$ 45.00$ per acre

wildlife abounds at Geyser, there is deer hunting, elk hunting, fishing for native brown trout, bass in the hot springs, and rainbow trout in the mountain streams nearby. Multitudes of other wildlife are present on the ranch property.

Tortoise, lizards, and snakes plus jack rabbits and the occasional coyote are supported by the coyote spring valley. Deer do not range there; the big horn sheep are over the mountain. Aerojet's facility in california is a wildife paratise. They re-introduced species of flora and fauna that had been eliminated in the area. The ground looks like a wildiffe preserve. The addition of management can only enhance the lives of the wildife at the proposed Aerojet land exchange. 
TABLE OF ASSESSED VALUE

$\begin{array}{lcr}\text { Geyser Ranch Assessed Value } & 1982 & 4.5 \text { Million } \\ \text { Geyser Ranch Assessed Value } & 1987 & 2.5 \text { Million } \\ \begin{array}{l}\text { Lincoln County Assessed Value } \\ \text { Lincoln County Assessed Value }\end{array} & 1986-87 & 49,593,268 \\ \text { Value (Approximate) of Land In Exchange } & 1987-88 & 46,216,419 \\ \begin{array}{l}\text { Value (Approximate) of Improvements - } \\ \text { Est. 300 Million }\end{array} & 105,000,000 \\ \text { Value of Proposed Incinerator } & 4,600,000 \\ & \\ \text { Project Total County Value When Both } & \\ \text { Projects Are Completed }\end{array}$

This represents a 250 percent improvement in value of county and would increase county budgets 21 times! 


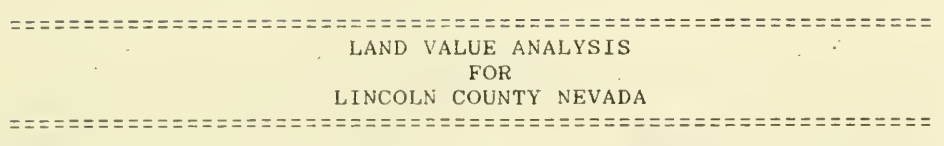

The figures used in this analysis have come from Lincoln County Realty and the appraisal files of Financial Designs. They are based on the average cost for a two and three bedroom home that is between. 15 and 35 years old. The dwellings are located on typical city lots.

The analysis covered a period of time from 1979 to the present. Alamo and pioche were the exceptions as there was insufficient data for the years 79 and 80 .

ALAMO

The property values in Alamo have decreased approximately 9 percent from 1985 to the present. The property values in Alamo peaked in 1982 and declined until 1986. They are now experiencing an upswing which may be due in part to speculation about Aerojet.

\section{CALIENTE}

The property values in Caliente have decreased approximately 20 percent from 1985 to the present. The property values in Caliente peaked in 1985. They have since been declining.

\section{PANACA}

The property values in Panaca have decreased approximately 26 percent from 1985 to the present. The property values in Panaca are now what they were in 1979. The property values peaked in the years of 81 and 82 and have declined from that time to the present.

\section{PIOCHE}

The property values in Pioche have increased approximately 11 percent from 1985 to the present. The property values in Pioche have experienced a recent increase in value. This can be attributable to the influx of retired individuals who have income and like the beauty and quiet that is unique to Pioche. 


\section{6}

\section{ADDENDUM III}

Page 2 of 7

GENERAL

Historically, Lincoln County has been tied to the mining industry. As the values in precious metals fluctuated so also did the population base. Increases and decreases in the population directly effect the value of land through the law of supply and demand.

Virtually all of Lincoln County has experienced a decline in property values over the past two years. On a county wide average, land values have decreased approximately 11 percent from 1985 to the present. Land values have not kept pace with inflation. These figures are alarming to county and City leaders as well as the business sector. Through less dependence on mining and the state government agencies that employ a large number of people and an increased effort for economic diversification, land values will have a basis to increase. An increase in land values is a good indication of a strong economy.

Figures were compiled by Gordon L Wadsworth, CFP, MRA, MFLA, a certified appraiser. 
ADDENDUM III

Page 3 of $7=$

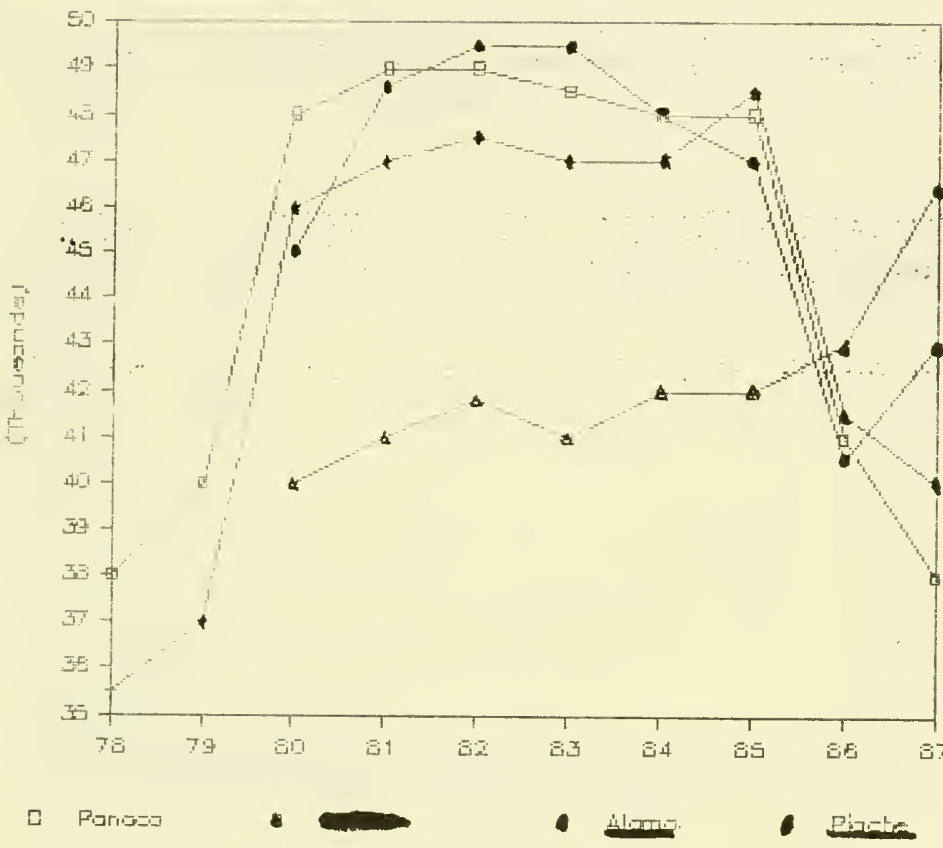




\section{8}

ADDENDUM III

Page 4 of 7

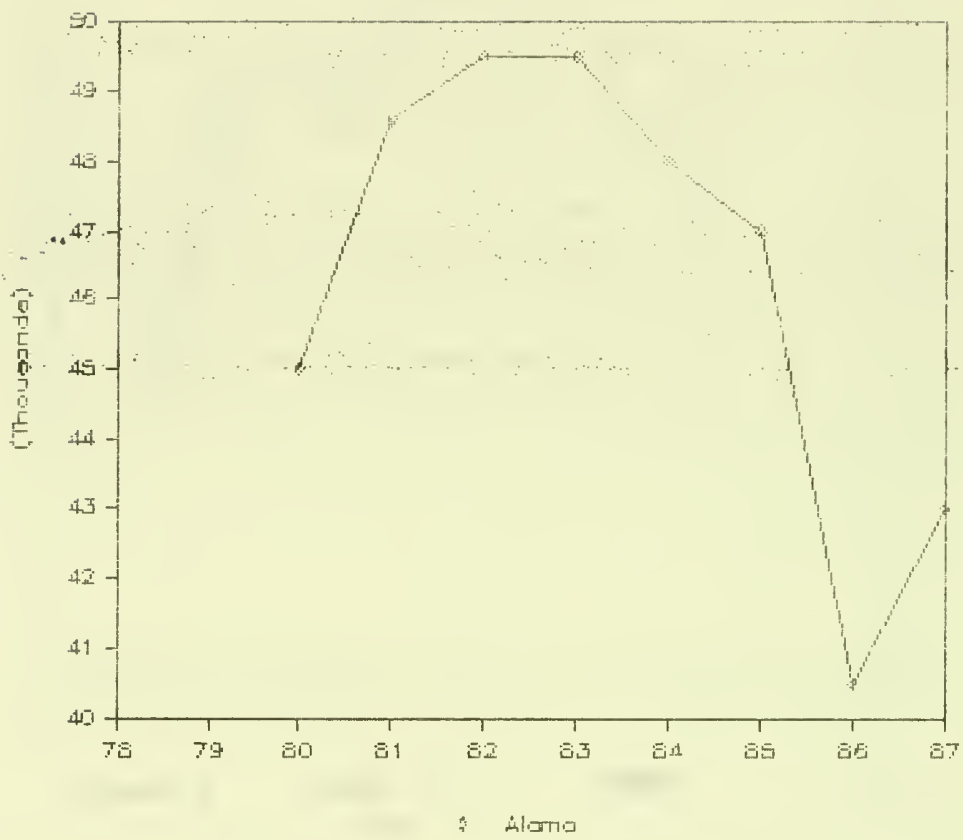


ADDENDUM III

Page 5 of 7

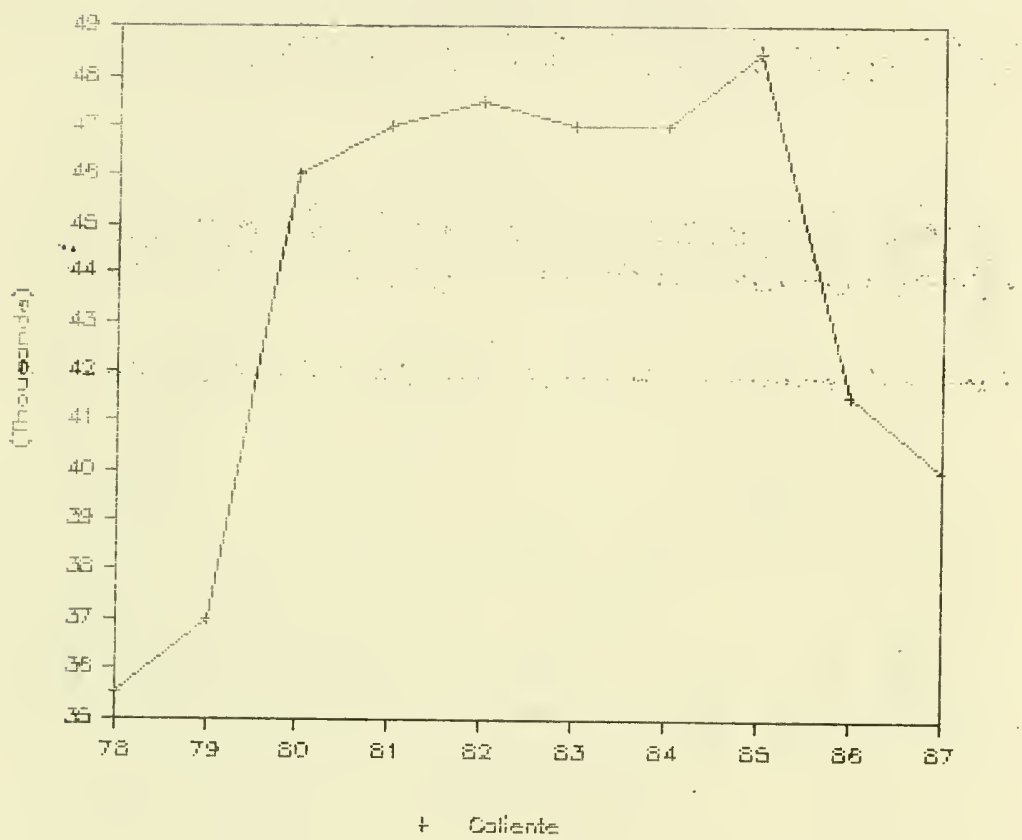


ADDENDUM III

Page 6 of 7

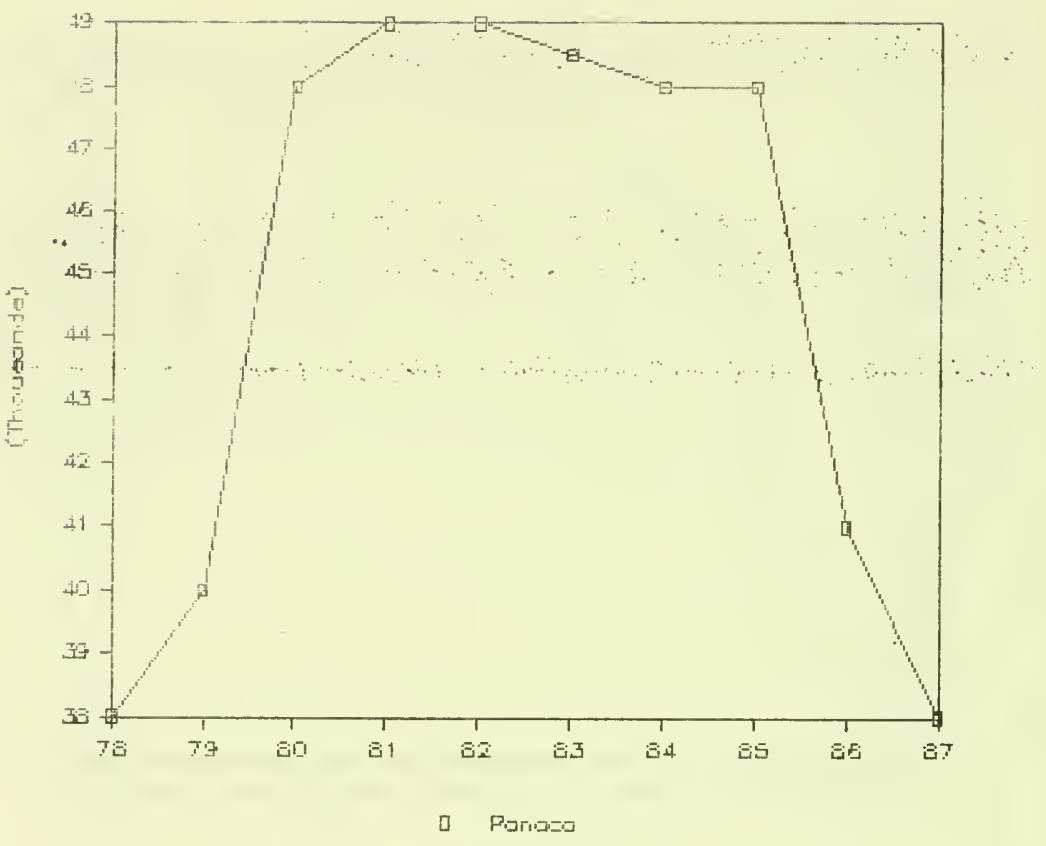


ADDENDUM III

Page 7 of 7

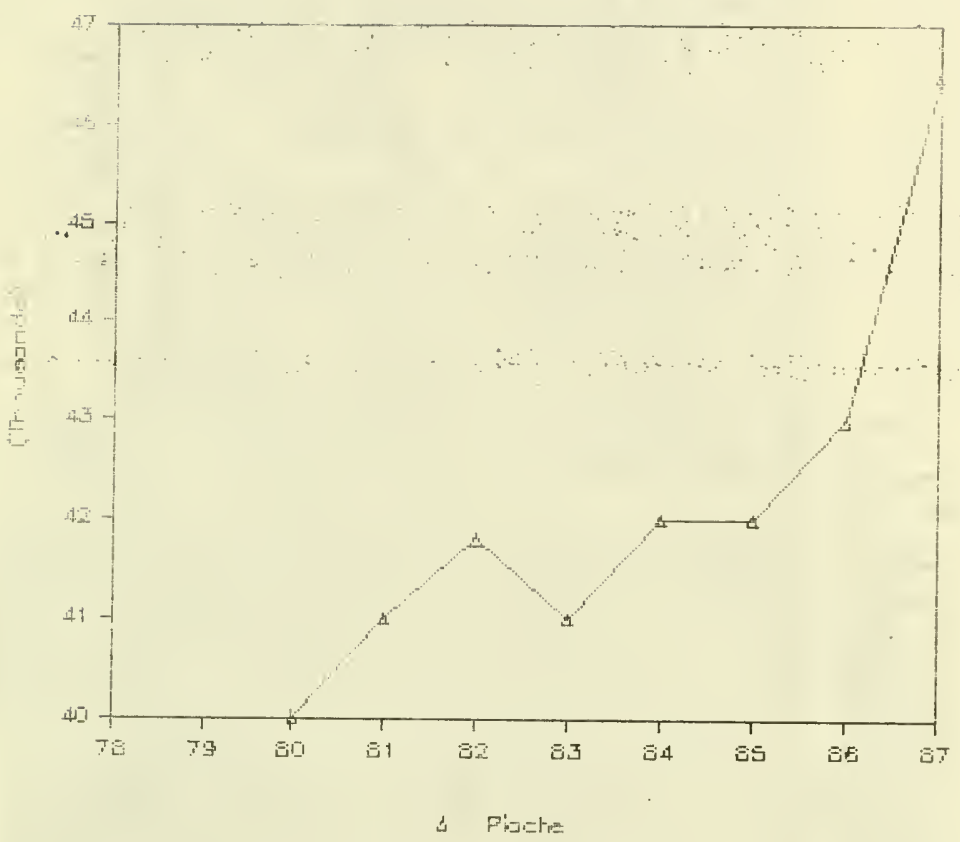




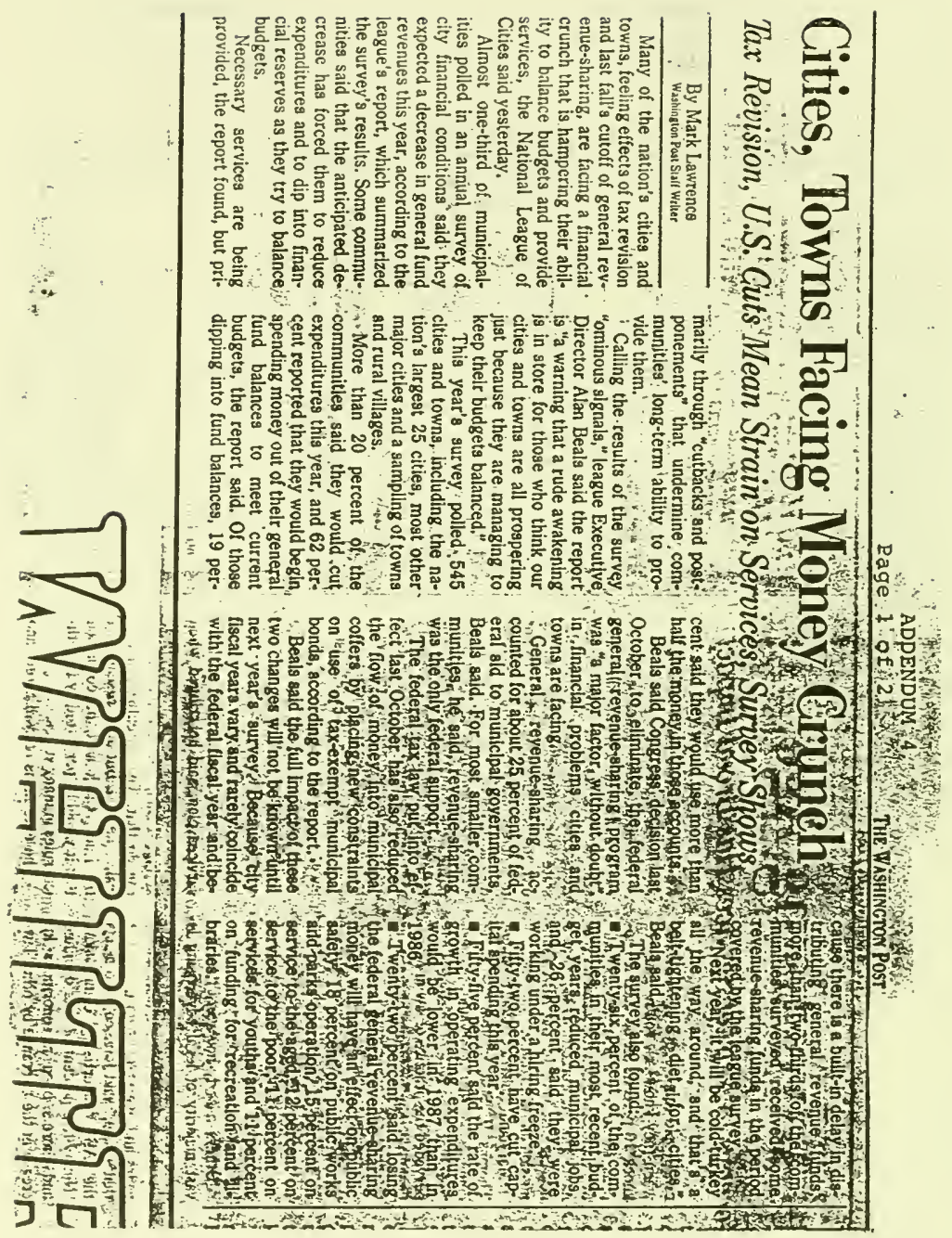




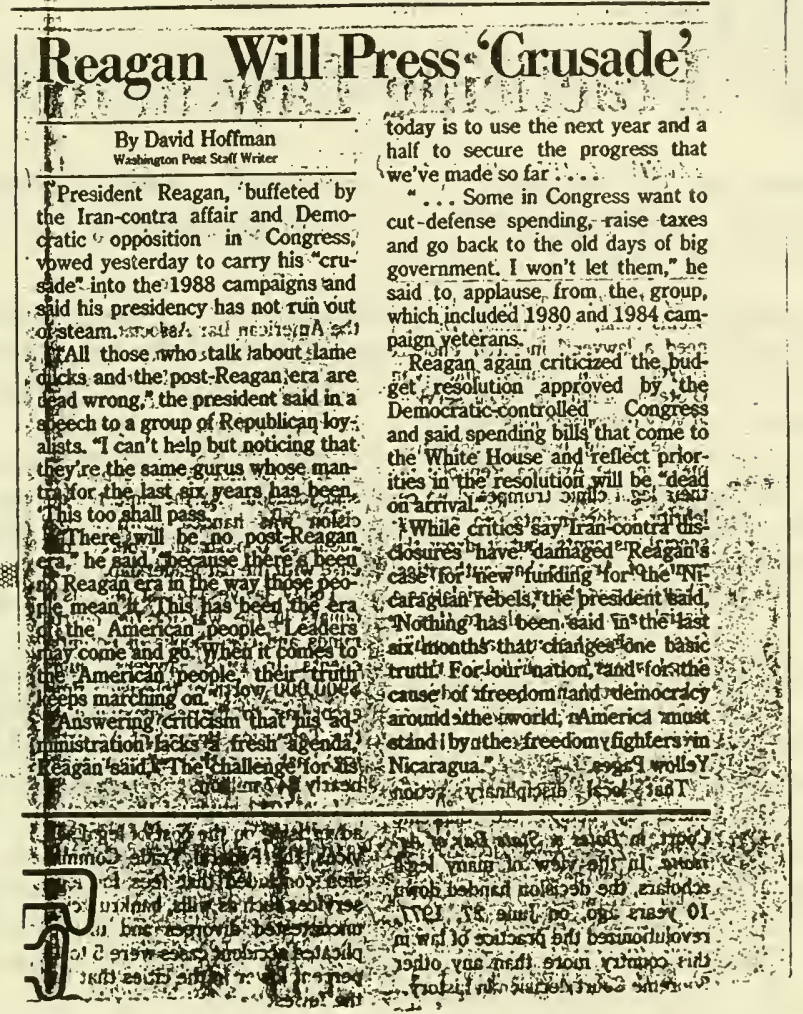


Senator Hechт. I need about 10 minutes of your indulgence, and I will be right back.

[Recess taken.]

Senator Hecht. Thank you very much. Dennis Bechtel, Coordinator, Department of Comprehensive Planning, Clark County, Nevada.

\section{STATEMENT OF DENNIS A. BECHTEL, COORDINATOR, CLARK COUNTY DEPARTMENT OF COMPREHENSIVE PLANNING, CLARK COUNTY, NV}

Mr. Bechtel. Thank you, Senator Hecht. I really appreciate the opportunity to be here. My name is Dennis Bechtel, planning coordinator for Clark County Department of Comprehensive Planning, located in Las Vegas, Nevada.

I appreciate the opportunity to testify this morning on two bills of importance to the citizens of Clark County and southern Nevada. Senate bill 854, the Nevada-Florida Land Exchange Authorization Act of 1987, proposing the exchange of land in the States of Nevada and Florida for the Aerojet General testing facility.

Senate bill 59, introduced by Senator Hecht, and its House equivalent, H.R. 267, introduced by Representative Vucanovich of Nevada, both known as the National Forest and Public Lands of Nevada Enhancement Act of 1987, propose the transfer of land between the Bureau of Land Management and the U.S. Forest Service of Nevada to further protect areas of scenic beauty.

Clark County, which encompasses the city of Las Vegas, includes a portion of the Aerojet General test facility proposed in S. 854, and a number of the administrative and other operations which will be located in metropolitan Las Vegas.

With regard to S. 59, land adjacent to Mt. Charleston, the most obvious reference point, some 40 miles from Las Vegas, an important recreational resource currently under control of the Bureau of Land Management, is being considered for transfer to the Forest Service.

Among the responsibilities of the Department of Comprehensive Planning is the evaluation of the potential impact of projects such as the proposed Aerojet facility on our local environment and citizens.

Staff has subsequently examined the potential consequences of the proposed bills on our area of governmental responsibility and have the following comments.

With regard to S. 854, the Nevada-Florida Land Exchange. The Clark County Department of Comprehensive Planning supports S. 854.

S. 854 proposes the transfer of 4,650 acres of land located in the sensitive wetlands area of Florida for 51,710 acres of public land currently under the Bureau of Land Management administration in the Coyote Springs and Garfield Flat areas in Nevada's Lincoln and Clark counties.

The transfer of land can assist in protecting sensitive wetlands in southern Florida and also enable the important defense needs of 
the Nation to be met by providing the land for the construction of the test facility in southern Nevada.

The area in Nevada being considered is almost completely unpopulated, and with proper planning will offer minimal impact to the public and the environment. The location of the site with regard to metropolitan Las Vegas is illustrated in Map 1 which I have attached at the end of my testimony.

Staff also supports S. 854 for the potential economic benefits to southern Nevada. The project is especially important to the citizens of Lincoln County. The project would provide relief for the current economic difficulties being experienced in Lincoln County.

Likewise, the project will also assist in meeting the economic diversification needs of Clark County. The Aerojet project would complement the defense-related activities currently taking place in southern Nevada. We feel that the passage of the bill is important for the economic health of Nevada.

Clark County, it should be noted for the record, has a number of environmental and safety concerns associated with the proposed Aerojet General project.

Among these are the routing and handling of materials employed in the testing of rocket motors, the source and use of water at the site, and the presence of particularly sensitive habitat on the site for the desert tortoise, a threatened species in Nevada.

We have conveyed these concerns to Aerojet General personnel. To allay our concerns, for example, relative to the transport and handling of hazardous materials, we have noted to Aerojet General of the need to work closely with the Clark County Fire Department to insure that the provisions of the Clark County Hazardous Materials Transportation Act are met, and also to work with the state on their recently-enacted legislation on hazardous materials.

Because of the preliminary scope of the project, it is difficult to determine the complete range of impacts from the project at this time. We are certain, however, that the concerns expressed by Clark County and local environmental groups can be resolved.

We are especially gratified that Aerojet General has decided to set aside a number of acres of land as habitat for the desert tortoise within the project area. This will assist in protecting this important species.

In our meetings with Aerojet General staff, we have been impressed by the sensitivity shown with respect to local problems. Aerojet has also demonstrated an understanding of the issues as documented in the Draft Environmental Assessment FloridaNevada Land Exchange, produced by the firm.

The lines of communication between Aerojet and government is southern Nevada have been open and discussions constructive. Aerojet General personnel are working closely with county staff to mitigate any potential adverse effects of the project to Clark County.

We would urge the Subcommittee on Public Lands, National Parks, and Forests to support approval of S. 854. This project is important to the economy of Nevada and to the defense needs of the Nation. 
Now I would like to go and do S. 59, National Forests and Public Lands of Nevada Enhancement Act of 1987. S. 59 is also important to the citizens of Clark County and Nevada.

This bill and its companion bill, H.R. 267, are the result of a proposal by the Federal government in 1985 to transfer control of all public lands in Nevada, including those located in the Toiyabe and Humboldt National Forests to the BLM.

Opposition to the transfer of Forest Service land to the BLM resulted in a controversial multistate bill and a separate 1986 bill for Nevada, which subsequently died in committee.

S. 59 addresses and rectifies many of the concerns expressed by the citizens and elected officials of Nevada under earlier legislation. The Clark County Board of County Commissioners has not taken formal action on the proposed bill, but it has a resolution of support on its July 7, 1987 board meeting agenda.

This we will submit to the board, should it be approved, and I have every feeling to believe that it will.

Staff comments to the proposed legislation are the following. S. 59 proposes to transfer some 511,000 acres of land currently administered by BLM in northern Nevada and in the Spring Mountain Range, to the Humboldt and Toiyabe National Forests.

Map 2, which is attached to the rear of my testimony, illustrates the lands to be transferred in southern Nevada. The lands to be transferred to the Forest Service are coterminous with the existing national forest lands, are of scenic beauty, and should be included within the administration of the Forest Service.

In many cases, the lands included in the transfer are, as an example, part of the same watersheds. It is, therefore, logical and would be more efficient if they are managed by the same agency.

The public lands transferred by the act contain valuable natural resources, which will be afforded the opportunity of management by the professional expertise of the Forest Service.

Tourism is, of course, a major sector of Nevada's economy. Much of Nevada's tax revenues are derived from tourist dollars. In addition to Nevada's casinos, visitors also flock to Nevada to take advantage of the camping, boating, wilderness opportunities available.

The change in designation of the forest lands to BLM may, in fact, eliminate the public's consideration of these lands as vacation opportunities and subsequently reduce the revenues from this source.

These revenues are especially important to rural communities that often have little other source of income. Expanding the boundaries of the national forest land, as well as maintaining its control under the auspices of the National Forest Service will assist in maintaining this important tourist function for the State of Nevada.

To summarize, staff urges the subcommittee to support S. 59, as well as S. 854 described earlier. Both bills are extremely important to the citizens of Nevada. Thank you.

[The prepared statement of Mr. Bechtel follows:] 
TESTIMONY OF

DENNIS A BECHTEL, COORDINATOR

CLARK COUNTY OEPARTMENT OF COMPREHENSIVE PLANNING

CLARK COUNTY (LAS VEGAS), NEVADA

ON

S. 854 ON NEVADA/FLORIDA LAND EXCHANGE

AUTHORIZATION ACT OF 1987

AND

S. 59 AND H.R. 267

NATIONAL FOREST AND PUBLIC LANDS

OF NEVADA ENHANCEMENT ACT OF 1987

BEFORE THE PUBLIC LANDS

NATURAL PARKS AND FORESTS SUBCOMMITTEE

OF THE

SENATE COMMITTEE ON ENERGY AND NATURAL RESOURCES

WASHINGTON, D.C.

JUNE 30,1987 
I am Dennis Bechtel, Planning Coordinator for the Clark County Department of Comprehensive Planning in Las Vegas, Nevada. I appreciate the opportunity to testify this morning on two bills of importance to the citizens of Clark County and southern Nevada.

Senate Bill 854, "The Nevada/Florida Land Exchange Authorization Act of 1987," proposes the exchange of land in the states of Nevada and Florida for the Aerojet General testing facility. Senate Bill 59, introduced by Senator Hecht and its House equivalent H.R. 267, introduced by Representative Vucanovich of Nevada, and both known as the "National Forest and Public Lands of Nevada Enhancement Act of 1987", proposes the transfer of land between the Bureau of Land Management and the U.S. Forest Service in Nevada to further protect areas of scenic beauty.

Clark County, which encompasses the city of Las Vegas, includes a portion of the Aerojet General test facility proposed in S. 854 and many of the administrative offices which will be located in metropolitan Las Vegas. With regard to S. 59/H.R. 267, land adjacent to Mt. Charleston, some 40 miles from Las Vegas and an important recreational resource currently under control of the Bureau of Land Management is being considered for transfer to the Forest Service.

Among the responsibilities of the Department of Comprehensive Planning is the evaluation of the potential impact of projects such as the proposed Aerojet facility on our local environment and citizens. Staff has subsequently examined the potential consequences of the proposed bills on our area of governmental responsibility and have the following comments. 
S. 854

\section{NEVADA/FLORIDA LAND EXCHANGE}

AUTHORIZATION ACT OF 1987

The Clark County Department of Comprehensive Planning supports S. 854 .

S. 854 proposes the transfer of 4,650 acres of land located in a sensitive wet lands area of Florida for 51,710 acres of public land currently under Bureau of Land Management administration in the Coyote Springs and Garfield flat areas in Nevada's Lincoln and Clark Counties. The transfer of land should protect sensitive wetlands in southern Florida and also enable the important defense needs of the nation to be met by providing the land for the construction of the test facility in southern Nevada. The area in Nevada being considered is almost completely unpopulated and with proper planning will offer minimal impact to the public and environment. The location of the site with regard to metropolitan Las Vegas is illustrated in Map 1.

Staff also supports the project for the potential economic benefits to southern Nevada. The project is especially important to the citizens of Lincoln county. The project would provide relief for the current economic difficulties being experienced in Lincoln County. Likewise, the project will also assist in meeting the economic diversification needs of Clark County. The Aerojet project would complement the defense-related activities currently taking place in Nevada.

Clark County, it should be noted, has a number of environmental and safety concerns associated with the project. Among these are the routing and handling of materials employed in the testing of the rocket motors, the 
source and use of water at the site and the presence of particularly sensitive habitat on the site for the desert tortoise, a threatened species in Nevada. We have conveyed these concerns to Aerojet General personnel. Because of the preliminary scope of the project, it is difficult to determine the complete range of impacts from the project at this time. We're certain, however, that the concerns expressed by Clark County and local environmental groups can be resolved. In our meetings with Aerojet General staff, we have been impressed by the sensitivity shown with respect to local problems. Aerojet has also demonstrated an understanding of the issues as documented in the "Draft Environmental Assessment Florida-Nevada Land Exchange" produced by the firm. The lines of communication between Aerojet and government in southern Nevada have been open and discussions constructive. Aerojet General personnel are working closely with County staff to mitigate potential adverse effects of the project.

We would urge the Subcommittee on Public Lands, National Parks and Forests to support approval of S. 854 . This project is important to the economy of Nevada and to the defense needs of the nation.

S. $59 /$ H.R. 267

"NATIONAL FORESTS AND PUBLIC LANDS OF NEVADA ENHANCEMENT ACT OF $1987 "$

S. 59/H.R. 267 are also of importance to citizens of Clark County and Nevada. These bills are the result of a proposal by the federal government in 1985 to transfer control of all public lands in Clark County including those located in the Toiyabe National Forest to the Bureau of Land Management (BLM). 
Opposition to the transfer of Forest Service land to the BLM resulted in a controversial multistate bill and a separate 1986 bill for Nevada which subsequently died in committee.

S. 59/H.R. 267 addresses and rectifies many of the concerns expressed by the citizens and elected officials of Nevada under earlier legislation. The Clark County Board of County Comissioners has not taken formal action on the proposed bills but has a resolution of support on its July 7, 1987 Board meeting agenda.

Staff comments to the proposed legislation are the following:

S. 59/H.R. 267 proposes to transfer some 511,000 acres of land currently administered by BLM in northern Nevada and in the Spring Mountain Range, north of Las Vegas, to the Humboldt and Toiyabe National Forests. Map 2 illustrates the lands to be transferred in southern Nevada. 23,000 acres of forest land will conversely be transferred to BLM in Mineral County. The lands to be transferred to the Forest Service are coterminous with existing national forest lands, are of scenic beauty and should be included within the administration of the Forest Service. In many cases, the lands included in the transfer are, as an example, part of the same watersheds. It is, therefore, logical and would be more efficient if they are managed by the same agency. The public lands transferred by the Act contain valuable natural resources which will be afforded the opportunity of management by the professional expertise of the Forest Service.

Tourism is, of course, a major sector of Nevada's economy. Much of Nevada's tax revenues are derived from tourist dollars. In addition to 
Nevada's casinos, visitors also flock to Nevada to take advantage of the camping, boating and wilderness opportunities available. The change in designation of forest lands to BLM may, in fact, eliminate the public's consideration of these lands as vacation opportunities and subsequently reduce the revenues from this source. These revenues are especially important to rural communities that often have little other source of income.

Staff urges the subcommittee to support S. 59/H.R. 267 as well as S. 854 described earlier. Both bills are extremely important to the citizens of Nevada. 


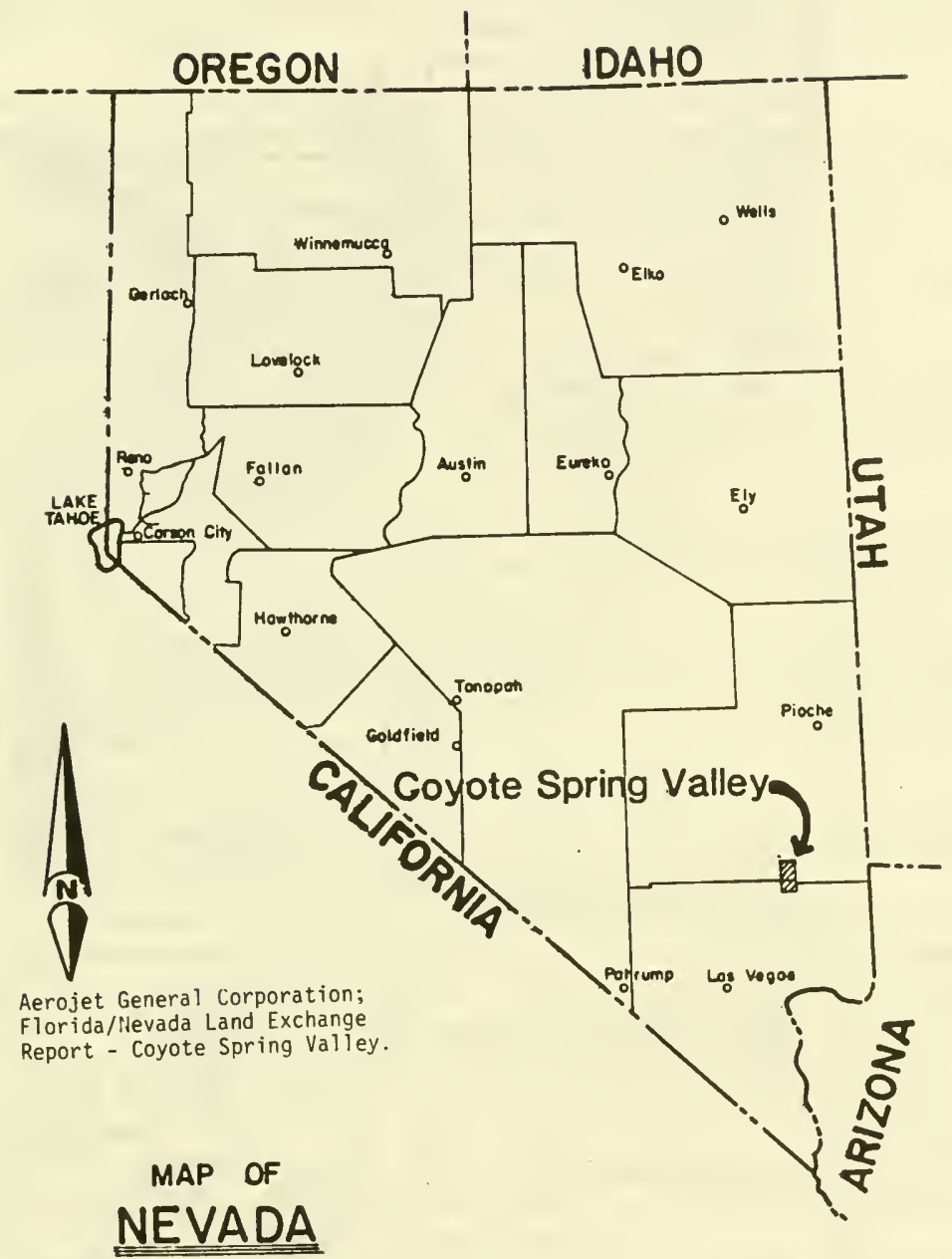

FIGURE 2.1 
MAP 2

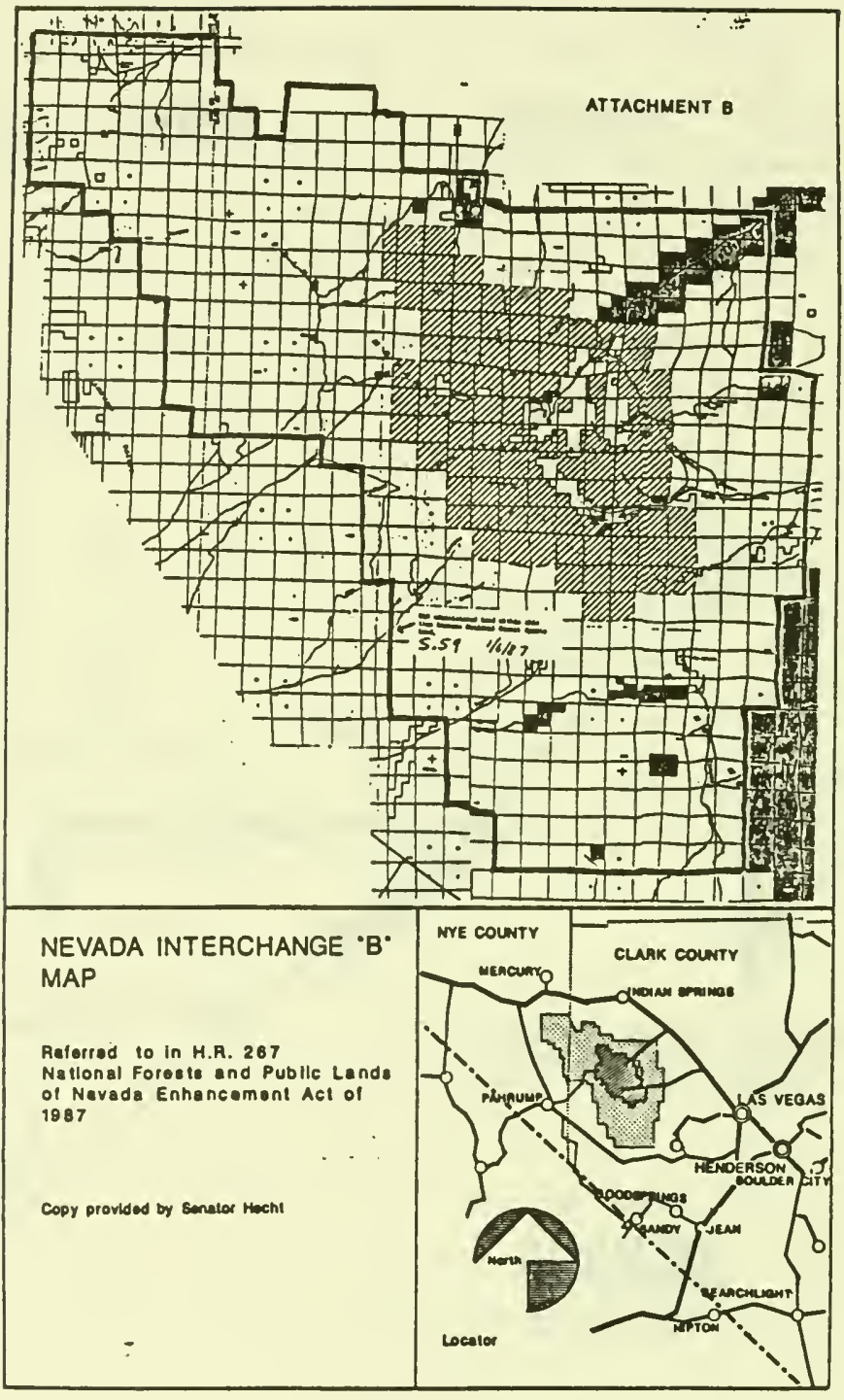


Senator Hechт. Thank you very much. Okay, Fred Wright?

\section{STATEMENT OF FRED WRIGHT, LEGISLATIVE AND ISSUES REP- RESENTATIVE, NEVADA WILDLIFE FEDERATION, INC., RENO, NV}

Mr. Wright. Thank you, Senator. Nice to see you again.

Senator Hecht. Good to see you. Thank you for coming.

Mr. Wright. I would like to thank you and Chairman Bumpers for holding this forum. I would like to address both bills.

Senator Неснт. OK.

Mr. Wright. And I am going to read a statement that I have shortened in deference to time.

Senator Hechт. Good.

Mr. Wright. For the record, I am Fred Wright, legislative and issues representative of the Nevada Wildlife Federation, a statewide sports and conservation organization and affiliate of the $\mathrm{Na}$ tional Wildlife Federation.

We are here today to discuss the wildlife issue. We are not taking up the issues of land values or the method of performing the transfer, should it occur.

In each debate over the Aerojet exchange that I have attended, wildlife is a controversial concern, that includes claims of dire impact. The issues that we will briefly cover are the national and Nevada wildlife ramification, the tradeoffs of economic diversification, and we have several recommendations to offer.

Concerning the national aspects, wildlife resources in Florida should benefit in that the Fish and Wildlife Service will ultimately be able to add to the National Wildlife Refuge System.

Our organization knows that as one of the fastest-growing states, percentage-wise, and being predominantly a public lands state, with minimum acreages on the tax roll, the change has to occur.

Further, we recognize Nevada's emphasis on economic diversification. Our mission, therefore, is to see that the wildlife resources receive a fair consideration as we move in that economic direction.

The actions that Aerojet agrees to take or will permit to be taken will result in reasonable mitigation and enhancement of wildlife values. Bighorn sheep, upland game birds, and their watering devices on-site and off-site have been addressed.

Extraction of ground water and its possible impacts upon wildlife, particularly endangered fish, and other water interests is the responsibility of the State Engineer first, and it falls under the state water laws for administration.

The primary loss from our point of interest is no further public use of the 42,000 plus acres of Coyote Spring Valley. The tradeoff will be economic benefit to Lincoln and Clark County, and hopefully new employment opportunities for Lincoln County residents.

The desert tortoise stands to gain under the proposal. While Nevada does not consider the tortoise to be threatened or endangered, some populations are in decline. Factors bearing upon the species are human encroachment on their habitat, livestock grazing, abusive off-road vehicle use, highway mortalities, collecting and holding reptiles as pets. 
Exhibit F, section 9 provides for setting aside 17,000 plus acres to enable and encourage continued study and observation of the desert tortoise. The area selected for the set-aside holds the higher populations of the general area and are considered as critical habitat in this vicinity by wildlife specialists.

By phasing out grazing, posting and patrolling the area for Aerojet security, and fencing the reduced vehicle mortality means the population will not be subject to the present random, indiscriminate uses and will benefit from reduced man-caused hazards.

In reality, a reserve is being created in Nevada for these reptiles, something that government has not yet done. The net effect would seem to be wildlife enhancement.

We have heard Aerojet testimony before the Nevada legislature in which the 17,000 plus acres set aside was described as a conservation reserve, with the declaration that it is to be in perpetuity as a property deed restriction.

How long the conservation reserve would exist and the prospects of future sale of the property have been contentious issues. Therefore, we suggest several strengthening amendments to section 9 , and they are detailed in our attachment $\mathrm{A}$.

Those amendments would do the following. Formally classify the set-aside as conservation reserve. Two, direct that the area description be recorded as a deed restriction upon successors in interest.

Three, remove the questionable need for an initial 20 year period. Four, directs that activities conducted within the conservation reserve be accomplished with minimum impacts on tortoise habitat. And five, use of the reserve for other than those stated will be guided and approved by a conservation reserve board.

In closing, while I am not in a position as representative of the Nevada Wildlife Federation to say that we support the exchange, neither do I say that we oppose it. This is due to our longstanding position of objecting to the removal of public lands from general use.

The tradeoffs are reasonable in this case, and balance and enhancement will occur. We have encouraged Aerojet to go beyond the stipulation of Exhibit $F$ that provides for an employee education program to heighten their awareness of the desert tortoise by their conducting a public relations program that adopts this critter, that has survived virtually unchanged for over some 17 million years, as their Nevada site mascot, and use the characterization of the tortoise as a logo and foster interest in this relic of the past.

The Department of Wildlife also has an opportunity to work with the utilities that will use the power corridor by doing so in a manner in which it respects the desert tortoise habitat and their needs.

Finally, our second recommendation to you is that a public hearing of some Congressional level be held in southern Nevada on the exchange program, and we understand that will be forthcoming.

Senator HECHT. That is correct.

Mr. Wright. And just briefly, in regard to S. 59-

Senator Heснт. Please summarize. You are over quite a bit right now. I do not want to cut you off. I have not cut off anyone else. But please summarize. 
Mr. Wright. I am a member of the Nevada Tas $k$ Force and also representing the Nevada Wildlife Federation. And we support S. 59 , with the one exception and one area where we feel the issue is moot.

We concur with the findings and the purpose of the act. The exception is the elimination of the BLM lands on and around Peavine Mountain, Washoe County, lands that were included in the 1986 act.

I feel the Federation would also support the addition of lands in southern Nevada that meet with the findings and purpose of the act. In our opinion, the highest and best use of those Peavine lands are watershed protection, recreation, and scenic background.

Mining would continue under the transfer as a legitimate use. Being in close proximity to the metropolitan Truckee Meadows area and the valley communities north of Peavine, there is a need for a more intense management of all activities than they have been receiving.

Mining on the site, therefore, needs to be better administered to be compatible with the other uses, thus minimizing hazardous sites close to the urban population.

We feel mining interest objections to more diligent surface management, and certainly any objections to bonding requiring reasonable reclamation of the site, should be considered secondary to the greater public benefit that would come from placing the area under the Forest Service jurisdiction.

The concern that miners will lose their one-stop shopping, that is having to deal with the Forest Service in addition to BLM, should be set aside in lieu of greater concern over how well the public lands are being administered.

In supporting S. 59, we want it understand that we recognize that the BLM professionals are concerned and diligent in their management efforts. But as an agency, they are so structured that they are more vulnerable to pressures of the commercial public land users.

While the proposed BLM Forest Service interchange was bad for Nevada, it produced a positive result. It brought out the generally held public belief that the Forest Service had a better reputation of natural resource protection and management.

It has a larger budget and is less subject to political pressure than BLM. Therefore, adding the lands to the forests in Nevada follows that public concept. We have actively encouraged local governments in Washoe County to support S. 59, with the inclusion of Peavine Mountain. To date, Washoe County commissioners and the Spark city council have each adopted a resolution in support.

In regard to the issue that we feel is moot from Nevada's perspective is reserve water, for all the reasons that you have heard. And we would hope that S. 59 does not become burdened with a national water issue.

Thank you for your time.

[The prepared statements of Mr. Wright follow:] 


\section{Nevada Wildlife Federation, Inc.}

An Affiliste of the National Wildlife Federation

Post Office Box 71238

Reno, Nevada 89570

\section{TESTIMONY OF FRED WRIGHT}

REPRESENTING THE NEVADA WILDLIFE FEDERATION, INC.

ON S. 59 (THE NEVADA NATIONAL FORESTS AND PUBLIC LANDS ENHANCEMENT

$$
\text { ACT OF 1987) }
$$

TO THE SUBCOMMITTEE ON PUBLIC LANDS AND-FORESTS IN

THE SENATE COMMITTEE ON ENERGY AND NATURAL RESOURCES

$$
\text { JUNE } 30,1987
$$

Good afternoon. My name is Fred Wright and I'm the Legislative and Issues Representative of the Nevada Wildlife Federation. The Nevada Wildlife Federation is the largest conservation organization in Nevada representing some 1,500 sportsmen and conservationists and 25 sportsmen's organizations. We are also the official state affiliate of the National wildlife Federation.

The Nevada Wildlife Federation is in support of the National Forest and Public Lands of Nevada Enhancement Act of 1987, as is evidenced by the passage of Resolution 14 on January 31,1987 , at our annual meeting in Las Vegas. However, our support of the Act has several exceptions. One of those exceptions deals with reserved water, which we understand caused Congressional objection to the 1986 Enhancement Act. 


\section{9}

TESTIMONY OF FRED WRIGHT, NEVADA WILDLIFE FEDERATION, JUne 30,1987

The Nevada Wildlife Federation feels the issue of reserved water is moot as it relates to this Act, due to Nevada's circumstance whereby the Truckee, Carson, and walker rivers which rise on National Forest lands are fully adjudicated. Due to the physical location of most of the lands to be transferred to the National Forest (downstream of existing forest land), the Act should be silent on that issue, rather than set a presumed precedence for other states ' Enhancement Acts.

Our other concern is the exclusion of most of the BLM lands around Peavine Mountain, Washoe County, just north of Verdi-Truckee Meadows. This area was Included in the 1986 proposed Act. Based upon the boundary associated with $\mathrm{S} .59$, only one half of one section is to go to the USFS. While this is an important one-half section that includes the head of Bull Ranch Creek and associated riparian areas containing a good stand of aspen and some white fir, it raises the serious question of why the rest of the BLM. lands were excluded in the 1987 Enhancement Act.

We have to assume that a request for exclusion was made by several local patented mine claim holders on the east side of Peavine Mountain. Several gentlemen having mining interests there appeared last fall before the Washoe County Planning Commission to express concern over the Reno Ranch Resort project that would develop approximately 460 acress of its 7,000-plus acre holdings around Peavine Mountain. They pointed out that a proposal in Congress (the 
TESTIMONY OF FRED WRIGHT, NEVADA WILDLIFE FEDERATION, June 30, 1987

1986 Enhancement ACt) would place everything west of U.S. 395 under the USFS and they said, "There's a lot of difference between the Forest Service and the BLM. If this proposal (1986 Enhancement Act) passes, it might affect some of the thinking regarding this project and might cause some problems for the applicant." The project was approved by the Planning Commission and by the Board of county Commissioners. Over 90 percent of the 7,000 acres will be retained in open space.

During the BLM/USFS Interchange hearings in Nevada, the common thread of input was that the USFS was more effective in the administration of its land than the BLM. Not because the professionals were not as concerned or as diligent in the BLM, but because the BLM is more vulnerable to political pressures of the commercial users of our public lands, a situation only congress can rectify. We, therefore, feel that concern over more active management of the Peavine Mountain area is what caused a request for exclusion.

Our support for the Forest and Public Lands Enhancement proposal is based upon the premise that changing administrative roles for the lands involved brings with in enhancement of professional multiple-use management by the respective agencies and results in improved

efficiency and more cost-effective management. That premise applies to the land around Peavine Mountain, only much more so due to its proximity to urban areas.

Peavine Mountain and environs is highly important to the adjacent urban areas for its watershed, scenic background, and recreational 
TESTIMONY OF FRED WRIGHT, NEVADA WILDLIFE FEDERATION, June 30,1987

use. With regard to mining, there are approximately 560 acres of patented mining claims held mostly by nonresidents, the us Government, and the primary developer in the McQueen Planning Area. There are approximately 150 unpatented mining claims on the BLM lands, some now adjacent to residential developments. The patented mining claims will not be affected by an administrative change were it to occur. New mining ventures on public land would come under stricter surface control and bonding requirements to assure site reclamation if the USFS were administering the area. Because there is interest in mining in the area, we feel that the stricter management measures required by the USFS are highly justified, considering the heavy use the area receives from the public.

Recreational use of the public and private (presently posted) land includes sightseeing, picnicing, participation in snow sports, off-road vehicle driving, and deer huting, among others. The general area is used by wintering deer, with the highest numbers in the key. wintering area.

Peavine Mountain is home to a resident population of $100-200$ deer and a wintering population of up to 2,000 animals depending upon the overall size of the Loyalton-Truckee interstate deer herd and the severity of the winters in California. Washoe County is adopting the Verdi Area Plan which recognizes the value of retaining views, scenic features, and wildife habitat in conjunction with development on private lands. The north Peavine watershed is being evaluated to 
TESTIMONY OF FRED WRIGHT, NEVADA WILDLIFE FEDERATION, June 30,1987 determine how the runoff may be used to recharge north valley area ground water.

Due to the area's many values to washoe county citizens, it deserves more attention, management-wise, and that attention can be devoted by the U.S. Forest Service, along with local government involvement. As previously stated, we feel the highest and best management of the area is for watershed protection, scenic background, and recreational uses.

Mining under the USFS can continue as a legitimate use of the national forest lands as mandated by lar. The only difference would be more responsible reclamation of new claims. Existing patented mining claims and access to them will not be affected. Therefore, we respectfully request that the proposed boundary in the 1987 Act remain as it was in the 1986 Act--all lands west of U.S. 395 from the state line through Reno.

I would like to thank you for your consideration and would be happy to answer any questions that you might have. 


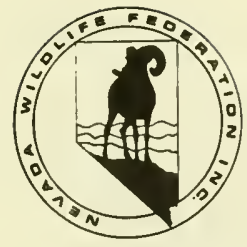

\section{Nevada Wildlife Federation, Inc.}

An Affitiate of the Notional Wildifte Federation

Post Orfice Box 71238

Reno, Nevada 89570

REPRESENTING THE NEVADA WILDLIFE PEDERATION, INC.

CN S.854 (NEVADA-PLORIDA LAND EXCHANGE AUTHCRIZATION ACT OP 1987)

TO THE SUBCOMMITTEE ON PUBLIC LANDS AND FCRESTS IN

THE SENATE CCMNITTEE ON ENERGY AND NATURAL RESOURCES

JUNE 30,1987

My name,for the record, is Fred Wright, Legislative and Issues Representative of the Nevada Wildlife Federation, a statewide sportsmen-conservation organization and an affiliate of the National Wildlife Federation. We are here today to discuss the wildlife issues that will result from the passage of 5854 . In each debate over the Aerojet exchange that I have attended, wildlife is of controversial concern and includes claims of dire impacts. The issues we will briefly cover are the national and Nevada wildlife ramifications and the trade-offs of econoric diversification and development versus loss of public use of the BLM lands. Finally, we have several recommendations to offer.

Concerning the national aspects of S854, we understand that wildlife resources in Florida will benefit in that the Fish and wildife Service will ultimately be able to purchase non-public lands to add to the National Wildife Refuge System in Plorida due to the exchange. For Nevada, we find that the wildlife issues have been adequately addressed as covered under Exhibt $P$ of the land exchange agreement referenced in S854. We will however be offering a strengthening amendment.

Cur organization knows that as one of the fastest growing states, percentage wise, and being predominately a public land state with minimum acreage on the tax rolls, that change has to occur. Further, we recognize that Nevada's emphasis is on economic diversification. cur mission therefore is to see that wildlife resources receive fair 
TESTIMONY OP PRED WIGHT, NEVADA WILDLIFE FEDERATION, June 30, 1987

consideration as we move in that economic direction. The actions that Aerojet agrees to take or will permit to be taken will result in reasonable mitigation and enhancement of wildlife values. Bighorn sheep, upland game birds and their watering devices on site and off site (guzzlers) have been addressed. Extraction of ground water and its possible impacts upon wildlife particularly endangered fish, and other water interests is the responsibility of the State Engineer and fall under state water law for administration.

The primary loss from our point of interest that will occur if S854 becomes law is no further public use of the 42,800 acres of Coyote spring valley and reduced access opportunity to west side of the Meadow Valley Mountains. The trade-off will be economic benefit to Lincoln County and Clark County and hopefully employment opportunities for Lincoln County residents to help offset the swings in mining boom and bust and reduced railroad employment.

The desert tortoise stands to gain under the proposal. While Nevada does not consider the tortoise to be threatened or endangered, some populations are in decline. Pactors bearing upon the species are human encroachment on their habitat, livestock grazing, abusive off-road vehicle use, highway mortalities, collection and holding the reptiles as pets which is illegal. The provisions in Exhibit $F$, Section 9 (pgs.3-4) provides for setting aside 17,885 acres to "enable and encourage continued study and observation of the desert tortoise." The area selected for set-aside holds higher populations in the genera? area and are considered as critical habitat by wildlife specialists. By phasing out grazing, posting and patrolling the area for Aerojet security and fencing to reduce vehicle mortality means the population will not be subject to the present random-indiscriminate uses and will benefit from reduced man-caused hazards. In reality, a reserve is being created in Nevada for these reptiles, something that government has yet done. The net effect would seem to be wildife enhancement.

We have heard Aero jet testimony before the Nevada Legislature's Senate and Assembly Committees that deal with natural resources in which the 17,885 acre set-aside was described as a "Conservation Reserve" with the declaration that it is to be in perpetuity as a 
TESTIMONY OF FRED WRIGHT, NEVADA WILDLIFE FEDERATION, JUne 30, 1987

property deed restriction. As the length of existence of the Conservation Reserve and the prospects of future sale of the property have been contentious issues, we suggest several strengthening amendments to section 9 (pgs. 3-4) of Exhibit $\mathrm{F}$ and embodied in our attachment $A$. Those amendments do the following:

1) Formally classify the set-aside as Conservation Reserve

2) Direct that the area description be recorded as a deed restriction upon successors in interest

3) Removes the questionable need for an inital 20 year period

4) Directs that activities conducted within the Conservation Reserve will be accomplished with minimum impact on tortoise habitat

5) Use of the reserve for other than those stated will be guided and approved by a Conservation Reserve Board anytime Aerojet has a need

In closing, while I am not in a position as representative of the Nevada Wildlife Federation to say that we support the exchange, neither do I say we oppose it. This is due to our long standing position of objecting to the removal of public lands from general use. The tradeoffs in this instance seem to be balanced and enhancement will occur. We have encouraged Aerojet to go beyond the stipulation in Exhibit $F$ that provides for an employee education program to heighten their awareness of the desert tortoise by conducting a public relations program that adopts this critter that has survived virtually unchanged over some 27 million years as their Nevada Site mascot, use a characterization of the tortoise as a logo and foster interest in this relict of the past.

Finally, our second recommendation to you is that a public hearing of some Congressional level be held in southern Nevada on the exchange proposal.

Thank you for this opportunity. 
Attachment (A) Proposed amendment to Exhibit F paragraph 9, pgs. 3 and 4 a part of the Land Exchange Agreement Between Aerojet General Corporation and the United States of America (Note: Brackets are deletions, underling is new text)

9. For the purpose of enabling and encouraging continued study and observation of desert tortoises located on Aerojet property, Aerojet agrees to set aside an area of the Coyote Spring Land, to be known as "Conservation Reserve" consisting of approximately 17,885 acres, specifically described in Attachment (1) to this Exhibit $F$ and shall be recorded by Aerojet as a deed restriction \#pon successors in interest to the land. [for a period of twenty (20) years from the date on which Aerojet acquires the Coyote spring Land. During such 20-year period] Aerojet agrees that the reserved acreage shall be used only for the installation of roads, water wells, utilities, facility signs or [other] wildlife protective measures agreed to in this Agreement. Further, it is agreed that activities conducted on the Conservation Reserve will be done in a manner that will minimize disturbance of the desert tortoise habitat.

[At anytime after such 20-year period has elapsed, Aerojet agrees that it shal] Use of the reserved acreage for any reasons other than those stated above [unless its propsed use is] shall be approve in advance by a majority of a seven-member conservation Reserve Board which shall consist of persons holding the following positions or by their designated representatives:

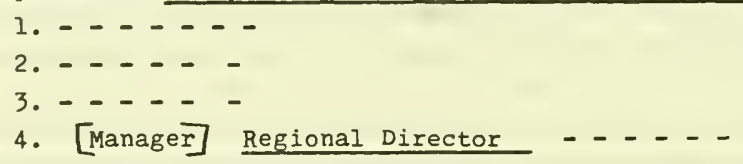

No further amendments suggested. 
Senator Hecht. Thank you very much. Ralph Clark, executive vice president and general manager, Aerojet General, North Las Vegas, Nevada.

\section{STATEMENT OF RALPH E. CLARK, EXECUTIVE VICE PRESIDENT}

AND GENERAL MANAGER, AEROJET NEVADA, NORTH LAS VEGAS, NV

Mr. Clark. Senator, thank you very much. For the record, my name is Ralph Clark. I am executive vice president and general manager of Aerojet Nevada.

Aerojet Nevada has its offices in North Las Vegas. And with your permission, Senator, I will paraphrase, because I think everybody has been sitting here too long. But I will try to hit the high points and certainly have written testimony.

Senator Hechr. Well, people have traveled a long distance and I just did not feel it was right to cut them off.

Mr. Clark. Oh, I am not arguing.

Senator HECHT. I agree with you.

Mr. Clark. Yes, sir. I would like to make a point that Aerojet has been working on this land exchange now, studying it in many aspects now for a bit over two years.

It has been my personal responsibility to direct that activity. In so doing we believe that we have addressed all of the issues that are proper to be addressed.

We have had numerous meetings with the Bureau of Land Management, the Department of Interior people, U.S. Fish and Wildlife, Nevada Department of Wildlife, Clark County Comprehensive Planning, local BLM agencies, local government people, and so on.

We have done, I think, just about everything that we can to display to various people what our plans are and what is behind them. I think we have been successful in some cases and obviously less successful in others.

I would like to make a comment that it is hard to coordinate with people when you can not find them. Together with my written testimony, I am including a list of organizations that we have sent environmental reports and preliminary drafts to, which we are still waiting to hear from.

I do not mean to say I do not hear from a grand forum such as this. But we do have a bit of trouble trying to iron out what may be things that can be ironed out, when I can not have specific comments and am not able to meet face to face to try to iron these things out.

We think again that we have done a good job with this, and have worked very hard to coordinate it. I would like, although I am sure you have seen it many times, Senator, for the benefit of others you will see on the easel up here a large picture of Coyote Spring Valley.

I do not know that I can add anything to the picture itself. If you look at the picture that is underneath it, and Rob, if you would that bottom one over one flip.

What you see on this map, Senator, is a satellite photo of south Florida. The red line is the boundary of the Everglades National Park. The portion west and south of that line is Everglades. 
If you see then, immediately adjacent to that, some green lines on there, they represent the Aerojet lands that are included in the land exchange, the so-called 4,650 acres.

The portion that is in yellow is an existing Aerojet plant site, which we are offering as an option to the State of Florida, for them to buy at today's price, the same $\$ 5.25$ an acre they are paying for the wetlands that are in green, providing Aerojet does not start using that site within seven years for national defense purposes.

We are in the finalization of that documented agreement with the south Florida water district. We have an agreement in principle now, and are working out those details.

You will notice a bit north of some of the green on the map some little checkered squares. Those are tomato farms. A number of people have suggested that tomato farms are involved in the land exchange.

I would like to say for the record, that is not true. South Florida, I think, believes they know what they want, and I am surely not going to second guess them. But they are not buying tomato farms.

There has been a great deal of talk about a conservation reserve. I would like to say that Aerojet offered that in its land exchange because we thought it was the right thing to do.

I think it was one of the number of many mitigations that we believe are right for this site. Mr. Fred Wright's comments that he just made about revising the words in it I agree with, and we will be working with the committee during markup, I hope, to cause that to happen in that manner.

I think at this point, Senator, again, recognizing that we are running out of time, if I can answer any questions you may have, I would be pleased to.

[The prepared statement of Mr. Clark follows:] 
TESTIMONY OF RALPH E. CLARK

EXECUTIVE VICE PRESIDENT AND GENERAL MANAGER

AEROJET NEVADA

ON S. 854

BEFORE

SUBCOMMITTEE ON PUBLIC LANDS, NATIONAL PARKS, AND FORESTS SENATE ENERGY AND NATURAL RESOURCES COMMITTEE JUNE 30,1987

Mr. Chairman and Members of the committee...

I appreciate very much the opportunity to appear before this committee today to discuss the proposed Nevada-Florida Land Exchange Authorization Act of 1987, s854. For the record, my name is Ralph Clark, and I am Executive Vice President and General Manager of Aerojet Nevada, which has its offices in North Las Vegas. Aerojet Nevada is a division of Aerojet General, which in turn is a wholly-owned subsidiary of GenCorp, a Fortune 500 company headquartered in Akron, Ohio.

With your permission, Mr. Chairman, I would like to make a short statement, and then answer any questions you may have.

At the outset, let me say how much we appreciate the support given this land exchange by members of the Nevada and Florida congressional delegations. The members and their staffs have gone out of their way to work on this project and we are sincerely grateful for their efforts.

Aerojet has been working on this land exchange proposal for more than two years, and it has been my personal

responsibility to direct this activity. The effort is part of Aerojet's long term strategic business plan, which forecasts the need for additional land to support Aerojet's growing business beyond land currently available at existing Aerojet facilities.

What has developed over the past years of extensive work by a variety of local, state and Federal agencies and Aerojet, is a plan which I strongly believe is a well thought out program which provides a multitude of benefits. In baseball, they say the best trade is one which definitely helps each team, and in this case I think we have exactly that situation.

Under this proposed exchange, the State of Florida acquires land which it would like to have to protect critical water flows through the Everglades and additional wildlife refuge lands in the area. The state of Nevada will be able to put some of its vast acreage to use for a commercial venture which will bring additional jobs and tax revenue to the state. The United States has increased options for its 
Testimony of R. E. Clark Continued:

future defense and aerospace work. Finally, Aerojet has the opportunity to accommodate its future growth requirements well into the next century.

Aerojet is one of the nation's leading aerospace and defense contractors. We have been in business for 45 years. We have made major contributions to programs such as Titan, Minuteman and Polaris missiles, the Titan as a space launch booster, and the Gemini, Apollo and the space shuttle manned programs. We also have been key participants in a number of highly successful secret programs.

Aerojet operates in three principal business areas--rocket propulsion, defense electronics and ordnance systems. Among the major programs where we are now contributing vital technology are the National Aerospace Plane, strategic Defense Initiative, Small ICBM, and SADARM--the very cost efficient anti-armor program.

If Aerojet is to continue to contribute to major space and defense programs in the coming years, we will need additional facilities. As we began to look for possible sites for these facilities, the proposed land exchange made eminent sense. Since we had some wetlands in Florida surplus to our needs and since Nevada is close to many of our current operations in the West, it seemed logical to try to arrange for this type of land exchange.

When we began our initial conversations with the Department of the Interior, it was made clear by both sides from the outset that any proposed exchange had to be equitable from a financial standpoint--that is, the land we were giving up in Florida had to be of equal value to the land which we would be acquiring in Nevada. That was not open to debate by either us or the Department of the Interior.

The state of Florida appraised the land which we were proposing to give up in this exchange, and at the same time we had professional appraisers--who were approved by the Bureau of Land Management--document land of approximate equal value in the State of Nevada. After these parcels were identified, the Bureau of Land Management reviewed the Nevada appraisal and agreed it was appropriate.

I wish to make it absolutely clear that Aerojet did not determine the land prices involved here. That was done by independent professional appraisers under instructions provided by the Bureau of Land Management.

After the parcels of land were selected which made sense for the land exchange, Aerojet invested more than a half of a million dollars in land studies, environmental surveys and economic studies on the proposed Nevada site. Complete environmental reports on the proposed exchange lands in 
Testimony of R. E. Clark Continued:

Nevada were provided to the Department of the Interior where they were reviewed and their findings agreed with. Those findings are documented in the Department's Resource Assertainment Report. With your permission, I would like to make the environmental report a part of the record at this point.

Throughout this process, we have attempted to meet with every conceivable group of interested individuals in both the State of Florida and the state of Nevada. We have circulated our environmental report to all of the major national and local environmental groups. We sought their reviews and input. Mr Chairman, I have here a list of the meetings which we have held with interested parties as we prepared this exchange as well as a list of those groups which have received copies of our environmental report. Both of these lists can be found in the addenda to my written testimony.

Obviously, it was not possible to respond positively to everyone from whom we received input. For example, the offroad vehicle enthusiasts wanted more open land, while the Desert Tortoise supporters asked for more land off limits. clearly, we cannot do both, and frankly the status quo will not permit both. However, we believe we have reached a beneficial decision.

A major issue we have been sensitive to since the outset of this exchange proposal has been the need to provide adequate protection for the wildlife resources within the exchange area in Nevada. As a result of these concerns, we have agreed to set aside some 29,000 acres within the coyote springs Valley in Nevada as areas which are restricted in use. This represents $70 \%$ of the entire coyote springs Valley exchange area. It is comprised of roughly 11,000 acres for a utility corridor and another 18,000 acres which will be reserved to protect the wildlife resources in the area--particulary the Desert Tortoise. As a result of these reservations, we feel we have an excellent blend of environmental protection and commercial land usage in a solidly compatible manner.

Mr. Chairman, we strongly believe Desert Tortoise will be better off under this proposed land exchange than they are now. The tortoise, which has been faced with a 50 percent "die-off" mortality rate in other parts of Nevada through poaching and other activities, will be protected on our property since the land will be posted and patrolled and tortoise will have ample area to survive. We are sincerely grateful to the help we have received from the Desert Tortoise council in commenting on our plans.

All in all, se have agreed to 11 stipulations with the Department of the Interior which both we and Interior 
Testimony of R. E. Clark Continued:

believe will fully mitigate any impact this exchange might have on the wildlife and cultural resources within the exchange area. Included in these stipulations is one which will provide increased protection to endangered fish which are located outside the exchange area.

I would also like to make it clear that Aerojet fully intends to use the land we may acquire under this legislation for aerospace and defense projects. We are not in the real estate acquisition and development business. We look at this as a project of the same significance as happened in the 1950s when we expanded from Southern california to a large facility outside of sacramento. We now have 4,000 employees working on a wide variety of aerospace and defense projects there.

In conclusion, let me repeat that we believe the exchange plan which has been developed through a cooperation effort among Aerojet, the various government agencies involved and concerned citizens will be beneficial and I urge this committee to positively consider these actions in your deliberations.

Mr. Chairman, we appreciate the consideration you are giving to this proposal, and we respectfully urge its passage. Again, I appreciate the opportunity to testify today, and would be happy to answer any questions.

Thank you. 


\author{
ADDENDUM I \\ TO : \\ TESTIMONY OF RALPH E. CLARK \\ EXECUTIVE VICE PRESIDENT AND GENERAL MANAGER \\ AEROJET NEVADA \\ ON $S .854$ \\ BEFORE \\ SUBCOMMITTEE ON PUBLIC LANDS, NATIONAL PARKS, AND FORESTS \\ SENATE ENERGY AND NATURAL RESOURCES COMMITTEE \\ JUNE 30,1987
}

\title{
SOME KEY ENVIRONMENTAL ISSUES ADDRESSED IN ENVIRONMENTAL REPORTS ( 1 )
}

At this time, I wish to introduce you to some of the specifics of the two environmental reports on coyote spring Valley and Garfield Flats. But before I do that, I think that I should advise you of Aerojet's basic goals. First, we realized once we set forth in this project, that all perceived environmental issues must be properly mitigated and these mitigation measures be designed to create and maintain conditions under which man and nature can exist in productive harmony. Second, we desired to establish a mechanism that would ensure these mitigation measures would be maintained for future generations of Americans. These Environmental Reports identify the issues suggested by federal and state agencies and environmental groups and the measures are identified in the stipulations of the proposed exchange agreement which set forth the mechanism to ensure future maintenance of these mitigation measures.

Let me first describe to you the Garfield Flat Environmental Report and several of the specific issues and mitigation measures addressed.

\section{GRAZING}

Presently, a Rancher (the Sweetwater Ranch) grazes his cattle on the area for three months a year. This grazing operation also utilizes several water sources and water distribution facilities for the site. We realized the socio and economic impact of our receiving ownership of this property and the rancher's if access was denied. Therefore,

(1) Full text of the environmental reports may be obtained from Mr. T. P. Griffin in Washington, DC at 202-828-6868 or Mr. R. E. Clark at 702-399-6411 in Las Vegas, NV. 
Aerojet and the Ranchers recently entered into a

lease agreement that provides for their continued access to the water and site for grazing purposes for the next ten years. The agreement will be renegotiated at that time.

\section{MINERAL CLAIMS}

Numerous mineral claims have been filed on the site by miners. In an effort to accommodate these claims, Aerojet is accepting ownership with the claims in place.

\section{WILD HORSES}

A historical wild horse herd use area has been identified on the site. Aerojet has no objections to their continued use of the site recognized by the fact the site will not be fenced. Additionally, we have offered as a mitigation measure to enter into a MOA with BLM which provides for their continued management of the herd.

Let me now address the Coyote Spring Valley Environmental Report.

\section{DESERT TORTOISE}

The tortoise is a species that we have been aware of and sensitive to since the beginning of this project. It resides on the site in varying degrees of densities identified as "low", "medium" and "high" tortoise habitat. As a result of this presence and the concerns expressed by the Desert Tortoise Council, we have recommended as a mitigation measure to establish an 18,000 acre conservation reserve within the medium and high density tortoise habitat. This preserve and other measures will provide a safe sanctuary for the future propagation and maintenance of the tortoise.

\section{WILDLIFE GUZZLERS}

The Nevada Department of Wildlife (NDOW) has constructed ten watersources called guzzlers on the site. The NDOW expressed concerns about the cost of guzzler construction and of access to the property for management of the wildife resources and maintenance of the guzzlers. We recognized these concerns and offered to reimburse NDOw for the cost of the guzzlers and to utilize an MOA as a mechanism that allows them future access for guzzler maintenance and wildlife management.

\section{DESERT BIGHORN SHEEP}

A desert bighorn sheep migration route borders on the Southeast corner of the site. The NDOW has expressed 
concerns about the location of future fences that may interrupt this historic route. In order to mitigate this concern, Aerojet has offered to consult with the NDOW prior to the siting and construction of any security fences in this area.

\section{LISTED ENDANGERED SPECIES}

Several 1 isted endangered aquatic species reside in springs 20 miles to the North and South of Coyote spring Valley. These species and their relationship to our search for water has been brought to my attention by the U.S. Fish and wildlife service in their section 7 consultation. These concerns are mitigated by Nevada Water Law which will establish any Aerojet water right as a junior right to the senior rights that exist presently in these springs. The state Engineer has indicated that any decrease in water quantity in these springs will require Aerojet to reduce or eliminate their use of the water. Additionally, we have agreed to jointly petition the state Engineer to determine the cause of any reduction in spring flows and reduce water use if Aerojet is the determined cause. 


\section{6}

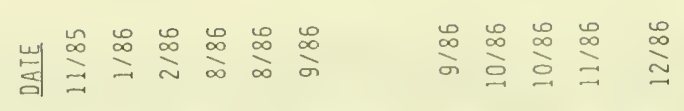
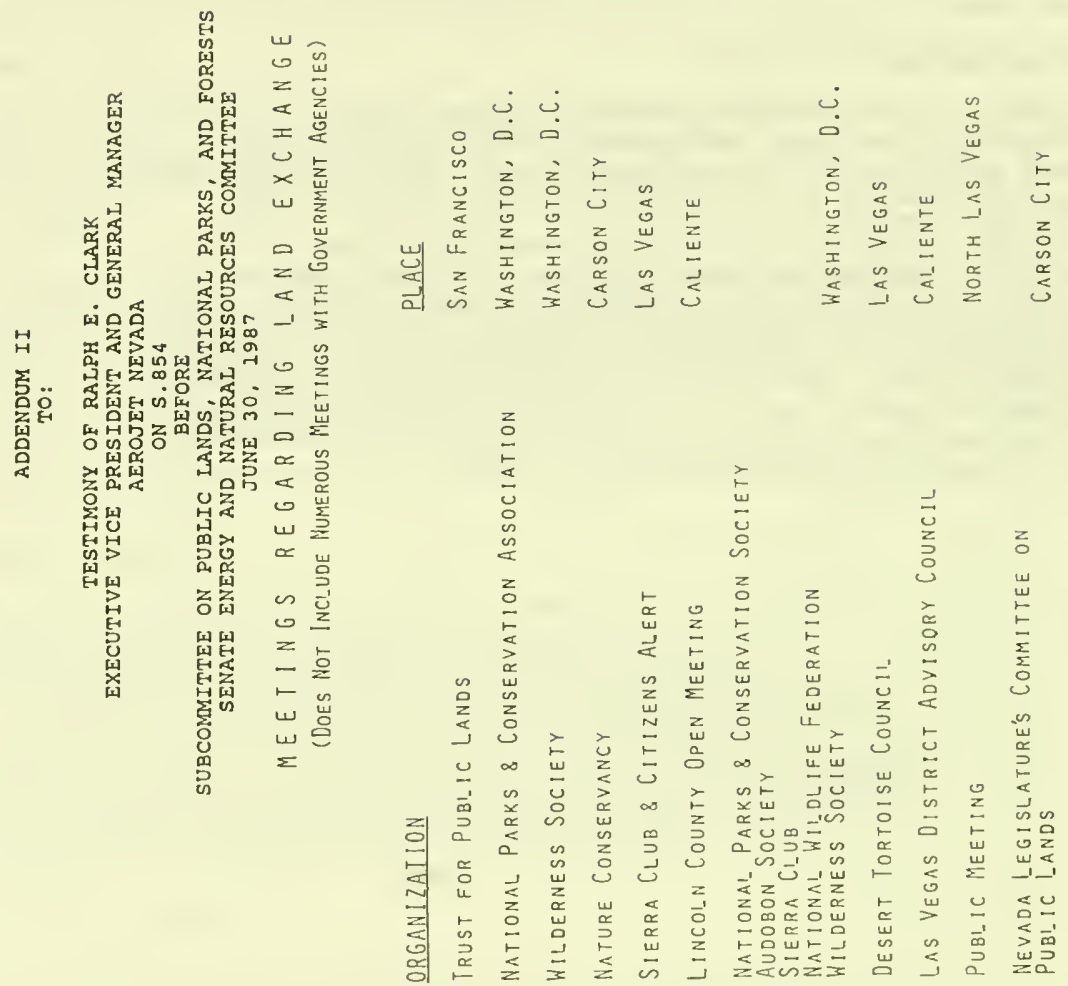


\section{7}

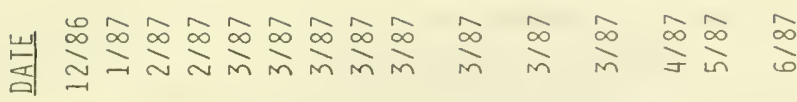

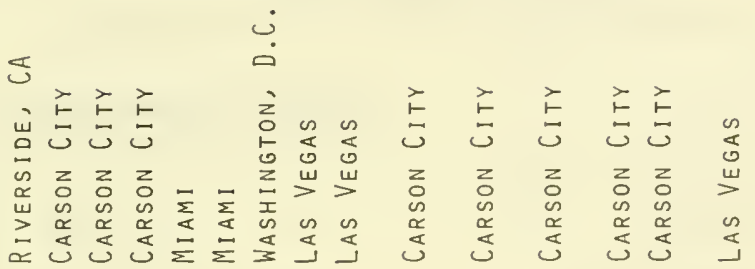

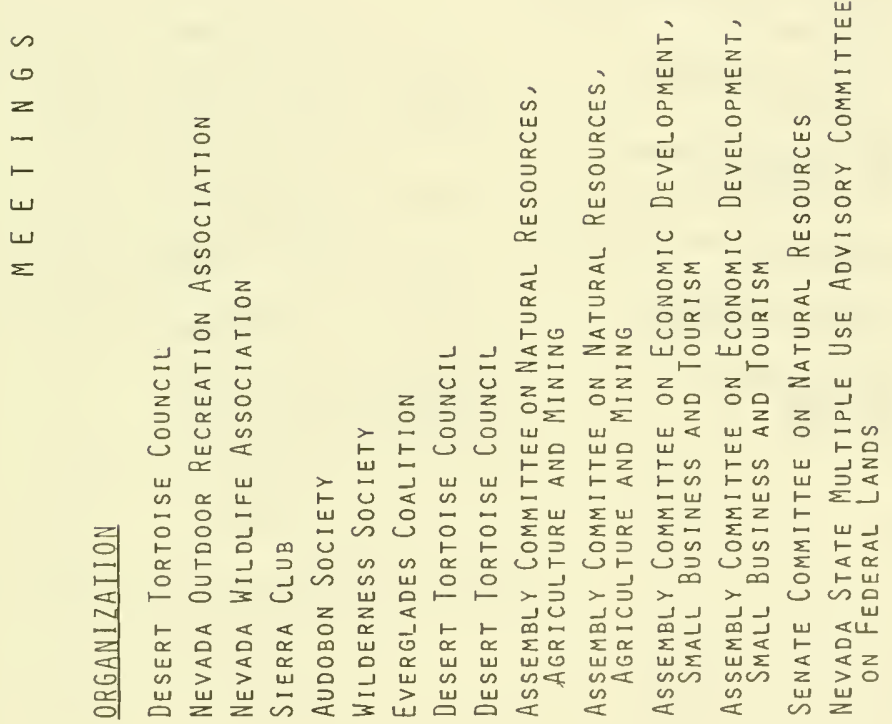


ADDENDUM III

TESTIMONY OF RALPH E. CLARK

ON S.854 BEFORE

SUBCOMMITTEE ON PUBLIC LANDS, NATIONAL PARKS, AND FORESTS

SENATE ENERGY AND NATURAL RESOURCES COMIITTEE

JUNE 30, 1987

PRELIMINARY DRAFT ENVIRONMENTATL ASSESSMENT

SENT TO ENVIRONMENTAL GROUPS

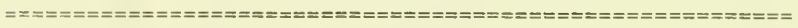

\begin{tabular}{|c|c|c|c|}
\hline Date: & Sent to: & $\begin{array}{l}\text { Telephone or Letter } \\
\text { Follow-up }\end{array}$ & $\begin{array}{l}\text { Commen } \\
\text { by Rec }\end{array}$ \\
\hline $12 / 10 / 86$ & $\begin{array}{l}\text { Desert Tortoise Council } \\
\text { (K. Berry) } \\
\text { Riverside, CA }\end{array}$ & No & Yes \\
\hline $12 / 16 / 86$ & $\begin{array}{l}\text { Citizens' Alert } \\
\text { Carson City, NV }\end{array}$ & Yes & None \\
\hline $12 / 18 / 86$ & $\begin{array}{l}\text { Nevada Outdoor Recreation Assoc. } \\
\text { (NORA) } \\
\text { Carson City, NV }\end{array}$ & Yes & None \\
\hline $12 / 23 / 86$ & $\begin{array}{l}\text { Red Rock Audobon Society } \\
\text { Las Vegas, NV }\end{array}$ & Yes & None \\
\hline $1 / 20 / 87$ & $\begin{array}{l}\text { National Parks \& Conserva- } \\
\text { tion Association } \\
\text { Washington, D.C. } \\
\text { Sierra Club/Washington office } \\
\text { Washington, D.C. } \\
\text { National Audobon Society } \\
\text { Washington, D.C. } \\
\text { Wilderness Society } \\
\text { (W. Butler) } \\
\text { Washington, D.C. }\end{array}$ & Yes & None \\
\hline
\end{tabular}




\begin{tabular}{|c|c|c|c|}
\hline Date: & Sent to: & $\begin{array}{l}\text { Telephone or Letter } \\
\text { Follow-up }\end{array}$ & $\begin{array}{l}\text { Comments provided } \\
\text { by Recipient }\end{array}$ \\
\hline \multirow[t]{2}{*}{$3 / 30 / 87$} & Audobon Society & & \\
\hline & Las Vegas, NV & Yes & None \\
\hline \multirow[t]{2}{*}{$3 / 30 / 87$} & $\begin{array}{l}\text { Desert Tortoise Council } \\
\text { (G. Stewart) }\end{array}$ & & \\
\hline & Long Beach, CA & Yes & None \\
\hline \multirow[t]{2}{*}{$3 / 30 / 87$} & $\begin{array}{l}\text { Desert Tortoise Council } \\
\text { (B. Burge) }\end{array}$ & & \\
\hline & Long Beach, CA & Yes & None \\
\hline \multirow[t]{2}{*}{$3 / 30 / 87$} & $\begin{array}{l}\text { Sierra Club of Nevada } \\
\text { (J. Van Ee) }\end{array}$ & & \\
\hline & Las Vegas, NV & Yes & None \\
\hline \multirow[t]{2}{*}{$3 / 30 / 87$} & Citizens' Alert & & \\
\hline & Las Vegas, NV & Yes & None \\
\hline \multirow[t]{2}{*}{$3 / 30 / 87$} & $\begin{array}{l}\text { Desert Tortoise Council } \\
\text { (K. Berry) }\end{array}$ & & \\
\hline & Long Beach, CA & Yes & None \\
\hline \multirow[t]{2}{*}{$3 / 30 / 87$} & $\begin{array}{l}\text { Defenders of Wildlife } \\
\text { (S. Johnson) }\end{array}$ & & \\
\hline & Las Vegas, NV & Yes & None \\
\hline \multirow[t]{2}{*}{$4 / 3 / 87$} & Defenders of wildlife & & \\
\hline & Sacramento, CA & Yes & None \\
\hline \multirow[t]{2}{*}{$4 / 3 / 87$} & $\begin{array}{l}\text { National Public Lands Task } \\
\text { Force and Nevada Outdoor } \\
\text { Recreation Association }\end{array}$ & & \\
\hline & Carson City, NV & Yes & None \\
\hline \multirow[t]{2}{*}{$4 / 3 / 87$} & Lahontan Audobon Society & & \\
\hline & Carson City, NV & Yes & None \\
\hline \multirow[t]{2}{*}{$4 / 22 / 87$} & $\begin{array}{l}\text { National Parks and Conserv- } \\
\text { ation Association }\end{array}$ & & \\
\hline & Washington, D.C. & Yes & None \\
\hline $4 / 22 / 87$ & $\begin{array}{l}\text { Sierra Club } \\
\text { Washington, D.C. }\end{array}$ & Yes & None \\
\hline
\end{tabular}


Environmental Report And Draft (cont'd)

Date:

Sent to:

Telephone or Letter

Follow-up

Comments provided by Recipient

$4 / 22 / 87$

National Audubon Society Washington, D.C.

Yes

None

$4 / 22 / 87$

Wilderness Society

Washington, D.C.

(S. Whitney)

Yes

None

$4 / 22 / 87$

Wilderness Society

Washington, D.C

(M. Fishel)

Yes

None 
ENVIRONMENTAL REPORT AND DRAFT LAND EXCHANGE AGREEMENT

Date: $3 / 2 / 87$

Governor Richara Bryan

State of Nevada

Date: $3 / 30 / 87$

Lenard Smith

Caliente, NV

Michael Dyal

City Manager

North Las Vegas, NV

Mary Manning

Las Vegas Sun Newspaper, NV

Christopher Beall

Las Vegas Review Journal, NV

Pat Shalmy

Clark County Manager

Nevada

Ben Collins

Bureau of Land Management

Las Vegas, NV
Richard Holmes

Clark County Comprehensive Planning

Nevada

U.S. Fish \& Wildlife Service Desert National Wildlife Range Las Vegas, NV

Nevada Department of Wildife Las Vegas, NV

Date: $4 / 3 / 87$

John Walker

State Clearing House

office of Community Services Nevada

Fred Wright

Nevada Board of Wildlife Commissioners

Randy MCNat

U.S. Fish \& Wildlife Service

Great Basin Complex

Reno, NV
Ed Spang

State Director/BLM

Reno, NV

Bob McQuivey

Nevada Department of Wildlife Reno, NV

Pete Morros

State Engineer

Division of Water Resources

Carson City, NV 
INDIVIDUALS/AGENCIES (cont'd)

\section{Date: $4 / 3 / 87$}

\section{Lew Dodgion}

Administrator

Division of Environmental protection

Carson City, NV

Pam Wilcox

Administrator

Division of State Lands

Nevada

\section{Date: $4 / 7 / 87$}

Commissioner Fred Schmidt

Nevada Public Services Commission
Jim Schofielo

State Assemblyman

Nevada 
ADVISEMENT OF BILL INTRODUCTION AND HEARINGS UPDATE

SENT TO INDIVIDUALS/AGENCIES

Date: $5 / 20 / 87$

Bob McQuivey

Nevada Department of Wildife

Lew Dodgion

Division of Environmental Protection

Nevada

Pete Morros

State Engineer

Division of Water Resources

Nevada

Ed Spang

State Director/BLM

Nevada

Jim Schofield

State Assemblyman

Nevada
Randy McNat

U.S. Fish \& Wildlife Service

Great Basin Complex

Nevada

Fred Wright

Nevada Board of Wildlife Commission

John walker

State Clearing House

office of Community services

Nevada

Pam Wilcox

Administrator

Division of State Lands

Nevada 
ADVISEMENT OF BILL INTRODUCTION AND HEARINGS UPDATE

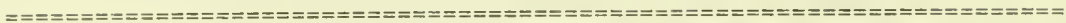

SENT TO ENVIRONMENTAL GROUPS

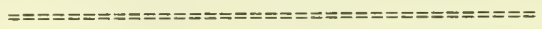

Date: $5 / 20 / 87$

Lahontan Audobon Society

Carson City, NV

National public Lands Task Force

Nevada Outdoor Recreational Association

Carson City, NV

\section{Date: $5 / 27 / 87$}

\section{te: $5 / 27 / 87$}

Desert Tortoise Council

(K. Berry)

Long Beach, CA

A

\author{
Audobon Society \\ Las Vegas, NV \\ Desert Tortoise Council \\ (G. Stewart) \\ Long Beach, CA
}

\section{Defenders of Wildlife Sacramento, CA}

Desert Tortoise Council

(B. Burge)

Long Beach, CA

\author{
Sierra Club \\ Las Vegas, NV \\ Citizens' Alert \\ Las Vegas, NV
}


Senator Hecht. Mr. Wallace Cavanaugh, with Crown Development and Mining, Wellington, Nevada.

\section{STATEMENT OF WALLACE J. CAVANAUGH, CROWN DEVELOPMENT \& MINING CO., WELLINGTON, NV}

Mr. Cavanaugh. I thought I would be speaking to Senator Bumpers when I made this next statement. I am going to carefully read it because since it involves you.

Last year a similar bill as S. 59 was submitted in the 99 th Congress, but it failed to get out of committee because of certain deficiencies which have since been corrected by this bill.

I am particularly appreciative of Senator Hecht's action to withhold a decision on last year's bill until these deficiencies could be addressed. I am aware he did so in spite of severe criticism from the Nevada press and other supporters of the bill.

The result of his efforts is an improved bill, one that I can support rather than oppose. The people of Nevada are indeed fortunate to have a person with such foresight and political fortitude as Senator Hecht to represent their interests in the United States Senate.

Senator Hecht. You can have all the time you want.

Mr. Cavanaugh. Thank you. I thought that might help a little bit. I am going to try to paraphrase the rest of the information I have.

I have been developing a group of mines for many years, actually 29 years to be exact, in the Pine Grove district of Lyon County, Nevada. This is all within the Toiyabe National Forest. The BLM land in question borders on this forest area known as the Pine Grove flats.

Recent advances in cyanide processing technology has made gold production a very productive operation, and has made the possibility of Pine Grove being a productive operation as well.

The Forest Service in that area has opposed the chemical milling process because of the sensitive nature of the environmental issues inherent in the use of cyanide. The State of Nevada agencies which have jurisdiction over the controls have given full approval for the project.

The problem I have had with the Forest Service, I just brought along because I hope to talk to the Forest Service this week, they have taken exception to the process and they prolonged the application procedures for about three years on this project, and there is nearly 500 pages of personal correspondence and another 350 pages of legal correspondence that has really held up the project.

For example, off the record here, you are talking about in this Aerojet thing about $\$ 40$ to $\$ 400$ evaluation. The Forest Service is requiring bonds that amount to $\$ 500,000$ to $\$ 100,000$ per acre evaluation.

Now this is not realistic. It is a form of intimidation to keep me from mining. As a matter of fact, after about three years in a lot of this nonsense, I am wondering why I am in the business. But I got the idea that maybe they really did not want me in their forest with the cyanide operation. 
So I started looking at BLM land, which is adjacent to the forest. I applied to the BLM earlier this year. The same application that I applied three years earlier. I got a one-page answer in two weeks time, with the same requirements, the basic same reclamation requirements, short of the inhibitation of bonding requirements.

In two weeks time I got a full approval for the operation. If you look at this, it is a real good paragraph. BLM has a good program for reclamation. They do not have some of the requirements for bonding that might prohibit an operation. But essentially, it is there.

These are in the record. Well, this document is in the record, and I have a summary in the record, attachment 1 , that summarizes my problem with the Forest Service, and I will not bother to read that at this point in time.

I might mention that my problem is not an exception. There is also a letter in here from Mr. Robert Warren, from the Nevada Mining Association, that outlines some of these problems, and addresses some of the reasons why this existed.

So we do have a problem. Now comes the bill from last year that proposed to include the land that I was going to move to, the BLM land, to be included in last year's bill. Fortunately it has been removed from this year's bill, so that should solve my problem.

But obviously a small miner can do with this, he can not do with this or the inhibitions that go along with a multi-buck process to even get into business there. So that is my problem.

Actually, through correspondence with your office I have proposed exclusion of certain areas, and I have outlined them into four basic areas. I will not go into detail. Essentially, the 1,700 acres that you included in the legislation as exclusions from the bill, and another for an enlarged area of 2,900 acres for a total 4,600 acres that I would really like to have addressed and looked at for full inclusion for a large-scale operation.

There is a potential here for a 30 million ton operation, which takes lots of room, lots of water, and lots of space. We are talking about flat desert ground, sagebrush-covered ground, the same kind of area that they are talking of in the other.

It is very low-cost and it is not very expensive to reclaim. Not in the degree that has been exposed to the Forest Service. So I have a kind of backhanded approach here.

I am really approving, or supporting the bill, but I would like to have it supported with this exclusion. We all in Nevada, and I from California, we support the effort to make Nevada a little greener with the Forest Service, as long as the government is willing to pay the additional cost and additional service.

But we do not want to spend any money like this for prohibiting business operations in areas that we can get into. That is why I appreciate your support on the further exclusion of the 4,600 acres.

[The prepared statement of Mr. Cavanaugh follows:] 
CROWN DEVELOFUENT AND NINING COMFANY

\author{
P. 0. Box 31 \\ wellington, Nevada 89444
}

Wallace J. Cavanaugh

8497 Carlton biay

Los Angeles, CA 90069

June 30,1987

To: The Honorable Dale Bumpers, Chairman

Sub-Committee on Fublic Lands, National Parks and Forests of the Committee on Energy and Natural Resources

Subject, Public hearing comments in support of $\mathrm{S}$. 59, a bill entitled "National Forests and Public Lands of Nevada Enhancement Act of $1987 "$

I wish to thank the Sub-Committee for allowing me the opportunity to present an oral and written statement in support of the bill.

Last year a similar bill was submitted to the 99 th Congress, but it failed to get out of committee because of certain deficiencies which have since been corrected in this bill. I am particularly appreciative of Senator Hecht's action to withhold a decision on last year's bill until these deficiencies could be addressed. I am aware he did so in spite of severe criticism from the Nevada press and other supporters of the bill. The result of his efforts is an improved bill, one that I can support rather than oppose. The people of Nevada are indeed fortunate to have a person with such foresight and political fortitude as Senator Hecht to represent their interests in the United States Congress.

My problem with the bill became critical when certain public lands now managed by the BLM were proposed to be transferred to the adjacent National Forest. I have been developing a group of mining claims for many years in the Pine Grove Nining District of Iyon County, Nevada, all within the Toiyabe National Forest. The BIM land in question borders this forest.

Recent advances in cyanide processing technology has made the commercial production of gold a favorable economic possibility for this property. The Forest Service has opposed the chemical milling process in this area because of the sensitive nature of the environmental issues inherent in the use of cyanides. The State of Nevada agencies, which have jurisdiction over environmental controls, have given their approval for the project.

The local Forest Service personnel have prolonged the application procedures for over three years in an attempt to prohibit the mill in this location. This has required nearly 500 pages of negotiation correspondence and the additional generation of 350 pages of legal documents by our attorneys. The government filed 
page 2 - S. 59 Lands Hearing

a civil lawsuit in 1984 for damages and injunctive relief when I exercised my right to perform annual assessment work while the dispute was pending. See Attachment No. I entitled "Overregulation of Mining in National Forests" for more details on the legal issues.

It became apparent that I would have to move the milling operation onto the adjacent BLM land if $I$ were to avoid a further dispute with the Forest Service. Application was made to the Department of the Interior for the identical process to be undertaken on the BIN managed land. They reviewed the application and returned a favorable approval within two weeks. They generally required the same reclamation requirements as the Forest Service but without the inhibiting restrictions. See Attachment No. 2 for more details on the BLM approval.

The BIM has historically shown a more knowledgeable capacity for management of the surface resources of mining property in Nevada. My problem with the Forest Service is not an isolated case. Attachment No. 3 is a letter to Senator Hecht from the Executive Director of the Nevada Mining Association, Mr. Robert E. Warren. It will elaborate on the subject and explain in more detail the circumstances which have caused the problem.

It would appear the only means available to ensure a successful milling operation will be to mill the ore outside of the forest boundary. Now comes the land interchange bill which originally proposed inclusion of the required BIM land within the Forest System. I am requesting Congress to exclude this area from the interchange in order that I may avoid the hardship of a renewed conflict with the Forest Service over the mill location.

The Pine Grove project includes four stages of heap leach milling. These stages are dependant on the availability of the ore reserves and the appropriate space for processing. They may be listed as follows with the item numbers indicated on the Attachment No. 4 map as alternate milling locations:
1. 500 ton pilot heap leach for test purposes.
2. 100,000 ton heap leach of proven dump ore.
3. 1,000,000 ton heap leach of indicated reserves.
4. $30,000,000$ to automated plant for possible reserves.

I understand Senator Hecht has already proposed exclusion from S. 59 the 1,700 acres of land which will be needed to mill those items of ore that may be transported by existing roads. I am hereby requesting an additional amount of 2,900 acres to allow for a future large-scale expansion as described by Item No. 4 . It would be more cost effective to locate the milling operation for this large amount of ore where the transpotation could be handled in a straight line gravity flow from source to destination. The additional area will also be used to transport water from other sources. 
page 3 - S. 59 Lands Hearing

I would appreciate favorable action by the Sub-Committee and the Nembers of Congress to exclude the entire referenced 4,600 acres from the S. 59 legislation.

Respectfully submitted,

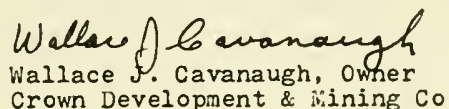


Attachment No. I

Overzealeous interpretation of the Surface Use Regulations ( 36 CFR 228) by U.S. Forest Service personnel has resulted in unreasonable inhibition of the legitimate activities of many prospectors and miners. This abuse of authority is particularly damaging to the small miner who does not have the financial resources to cope with the cost of increased restrictions. It also has a negative impact on those companies who can absorb the cost. Any increase in the cost of mining tends to limit the grade of ore that is economical to mine regardless of the operator's financial capability.

Part of the problem is a direct result of Forest Service policies which impose reclamation requirements in excess of those allowed by the regulations. These involve such items as cosmetic contouring to improve visual appearance, reseeding of all disturbed surfaces and bonding for cleanup after cessation of operations. These practices have been resisted by one small operator who feels the excess requirements are not reasonable and if allowed, there would be a steady escalation of similar restrictions which would eventually orive him out of business.

In 1984 the operator applied for a plan of operation to conduct a small cyanide heap leach operation to test the feasibility of leaching gold from mine dumps in a previously mined district of Lyon County, Nevada. An environmental assessment was conducted to evaluate the impact on the environment. It was determined (by the Forest Service) through the EA process that this was not a major Federal action that would significantly affect the quality of the human environment; therefore an Environmental Impact Statement was not required. There are no floodplains or wetlands and the work is outside of any Roadless Areas as previously inventoried.

The District Forest Ranger then imposed a series of reclamation requirements (cosmetic contouring, reseeding, etc.) which were to improve the visual appearance of the area after completion of the project. The operator reasoned that the required reclamation had nothing to do with protection of the land from erosion or landslides as prescribed in the regulation. The area is relatively flat and is covered with sage brush of no economic value. It is located at an elevation of 6600 feet where the natural reseeding of vegetation is more than adequate to allow the disturbed surface to recover in a reasonable period of time. Negotiation on this issue was not productive. The Ranger held firm to his decision. An approval of the Plan of operation was conditioned on the receipt of a bond to assure compliance with his demands. 
The situation was further complicated because the mining claim in question was supposed to be exempt from government jurisdiction of the surface resources. The claim was located in 1944 and was therefore protected from the restrictions of the Multiple Surface Use Act of July 23, 1955 (30 USC 601-615). The operator had applied for exemption under the "grandfather" clause of the Act. The mining claim was then validated by the Department of the Interior and affirmed in a document dated June 10, 1960. Forest Service personnel and their legal counsel claim the regulation has jurisdiction over all unpatented mining claims even when there is encroachment upon other statuatory rights.

The reclamation, bonding and jurisdiction issues were submitted to the administrative appeal process by the operator. The Forest Supervisor and the Regional Forester upheld the decision of the District Ranger. They also denied all Requests for Stay which would have allowed work to continue during the appeal. The operator then had a choice to go ahead with annual assessment work or lose the claims by default unless he were to submit to the bond requirement which would then establish a precedent for future imposition of similar restrictions.

Assessment work was undertaken and completed just in time to meet the deadline for that requirement. The government promptly filed a civil lawsuit to obtain an injunction and recover damages. See U.S. V. Cavanaugh, CV-R-84-422-BRT. A decision is still pending after two years of legal maneuvering by both sides.

The government has intended this to be a "test case" to establish their authority to administer the regulations in accordance with the agency interpretation of the requirements. This operator was targeted because he was a small miner with limited financial resources. He would be more likely to lose by default or otherwise than if a similar issue were made with a larger company.

The operator is equally dedicated to test the reasonableness of the regulations in a court of law and in effect to challenge the authority of the government to engage in this unnecessary interference with a legitimate mining operation.

The District Court in Reno, Nevada has scheduled a hearing on a motion for summary judgement on the jurisdiction issue for May 16, 1986 at which time a date will be set for the trial. More information will be provided to interested persons after these legal issues have been addressed. 
Attachment No. 2

S. 59 Lands Hearing

\section{United States Department of the Interior}

\section{BUREAU OF LAND MANAGEMENT \\ CARSON CITY DISTRICT OFFICE \\ 1539 Hot Spring Rd., Ste. 300 \\ Carson City, Nevada 89701}

Mr. Wallace J. Cavanaugh

8497 Carlton way

Los Angeles, CA 90069

Dear Mr. Cavanaugh:

We have received and reviewed the Notice you submitted for proposed precious-metal extraction activities on public lands described as T. 10 N., R. $26 \mathrm{E}$., Section $27(\mathrm{Nl} / 2)$. This Notice has been assigned the number NV-37-87-14(N) and it would be helpful if you would reference that number in any subsequent correspondence.

We note that you have elected to use the broad reclamation statement from the surface management regulations rather than to spell out the reclamation steps you plan. While this is an acceptable practice, I want to make clear at this juncture that, depending upon our evaluation of the project at its conclusion, we may, at a minimum, require physical shaping of the imported material or excavated material, neutralizing of anr cyanide-contaminated materials or areas, general site cleanup, and reseeding. Some of these anticipated measures may ultimately be deleted or modified after coordination with the state Division of Environmental Protection.

With the foregoing understood, your Notice is hereby accepted. You must notify us when the project is terminated and any necessary rehsbilitation accomplished so we can arrange the final field inspection.

Periodically throughout the life of your operation, we will perform site inspections to assure compliance with the accepted terms of the Notice.

You should contact Ron Buder of my staff if you have any questions or should you wish to discuss any facet of your project with us.

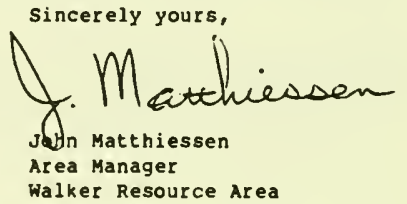


CROYN DEVELOPIENT AND WINING COMPANY

P. 0. Box 31

rellington, Nevada 89444

Vallace J. Cavanaugh

8497 Carlton Way

Los Angeles, CA 90069

January 28,1987

Bureau of Land ilanagement

Department of the Interior

1535 Hot Springs Road. Suite 300

Carson City, Nevada 89701

Certified ilail Number

F 243600407

Return Receipt Requested

Att'n: Mr. Ronald K. Buder

Dear Mr. Buder,

Re: Notice of Disturbance in Sect. 27, TION, R26E, IMDBN

This letter is written pursuant to the regulation 43 CFR 3609.1-3 to provide the required notice of the subject disturbance of the public lands.

(1) I am both the mining claimant and the operator. I am also the owner of the above named company. I operate seasonally from my field office (and residence) in tiellington, Nevada. Flease address any formal correspondence to my permanent home address in Los Angeles, California.

(2) The name of the mining claim to be disturbed is the PGF Millsite. It is a 5 acre unpatented millsite as shown on the attached map. It will be used to process ore from various mining claims located in Sect. 31, TION, R26E, NiDBM. The BLM claim numbers for the millsite are not yet available.

(3) A zero discharge closed circuit cyanide heap leach process will be used to extract minerals from the ore. The carbon adsorption system will be used to remove gold and silver from the cyanide solutions. Final recovery of the metallics from the carbon will be accomplished off-site. Oversize rock will be screened out at the mine with the fines (minus $1 / 2$ ) being hauled to the millsite by truck. The existing road will be adequate for this purpose. No new roads will be constructed. This disturbance is scheduled to start as early as April. 1987.

(4) Reclamation of all areas disturbed will be completed to the standard described in regulation 43 CFR $3809.1-3(d)$. Reasonable measures will be taken to prevent unnecessary or undue degradation of federal lands during operations.

\section{Sincerely,}

Attachment: Map

Hallace J. Cavanaugh 
304

Map Attachment for BLM Notice of Disturbance Dated January 28, 1987
PINE GROVE HILLS QUADRANGLE NEYADA-LYON CO 15 MINUTE SERIES (TOPOGRAPHIC) 323360000 FEE $1190^{\circ} 00^{\circ}$

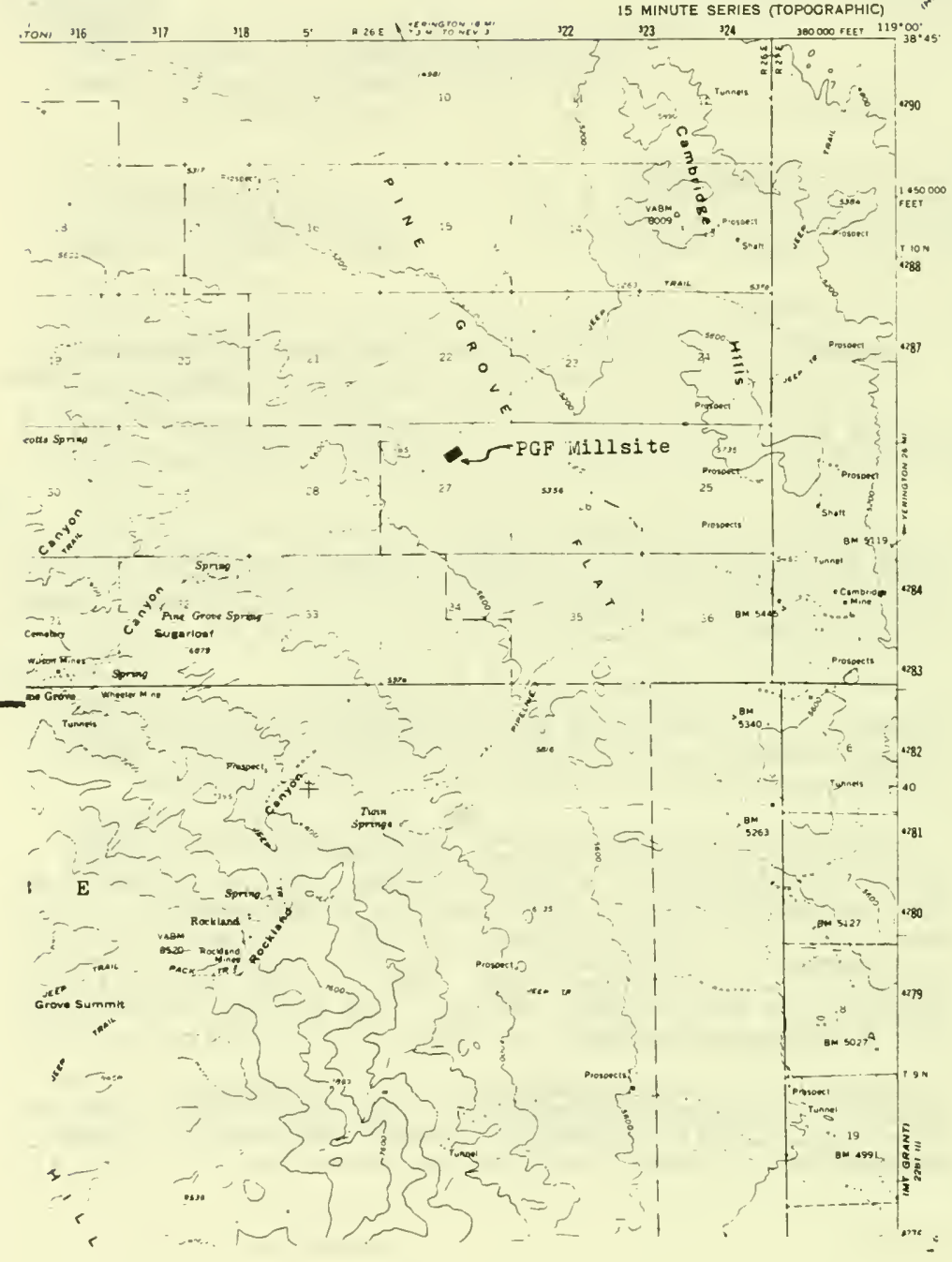




\title{
NEVADA MINING ASSOCIATION. INC. POST OFFICE BOX 2498 \\ RENO, NEVADA 89505.2498
}

\author{
ROBERT E WARREN \\ Eneculive Director \\ W. HOWARD WINN \\ Consulton!
}

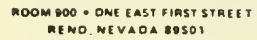

\section{nOABD OI DIRECTOR}

Richard a SUmit. Pretident OSEDM W MUlikR Y. Is, tce Presiden M. DAN MARPVD, 2nd Vice President V.V. DOTS

JAMES CASHMAN III LFONARD 1. ELLIOT MLAN J. KENNE DY CHN S. LTVEROSO DE: DT martine? REX L. OUTZEN DONATO L SIMPTON DONA.D L SIMPSON ALISN YOUNG ROBERTI, ZERGA

\author{
Honorable Chic Hecht \\ United States Senator for Nevada \\ 302 Hart Building, Suite 14 \\ Washington, D.C. 10510
}

\section{Re: Proposed BLM/Forest Service Land transfer - Letter from} Wallace J. Cavanaugh.

\section{Dear Chic:}

You have been contacted by Wallace J. Cavanaugh (September B) alerting you to his problem with the proposed transfer of certain lands from the Bureau of Land Management to the Forest Service (5. 2698).

Mr. Cavanaugh has advised he is developing a potentially large open-pit gold mine in the Pine Grove Mining District of the Toiyabe National Forest. (See map.) The transfer contains BLM lands on which his proposed heap-leach and milling facility would be located. Mr. Cavanaugh, based upon several years of Foresi Service delays and excessive regulatory zeal, predicts his proposed heap-leach and milling operations would experience additional costly delays and unnecessary and expensive additional regulatory requirements.

Unfortunately, the Nevada Mining Association is forced to agree that in too many instances of late the Forest Service has used its stepped-up "high intensity" management of surface resources to overwhelm mine exploration and proposed mining operations. We're being burdened by 100 much paper shuffling, excessive administrative requirements (sometimes whims of Forest Service employees), excessive regulations and excessive bonding. I should stress this "over kill" is not a problem within all units of the Forest Service in Nevada; but certain jurisdictions are generating heavy complaints from the mining industry.

We are now being informed that the new forest Service management program has become so restrictive that some major and small mining companies have incurred heavy expenses and have lost many months in attempting to respond to unrealistic and sometimes impossible requirements for use of the surface. In particular, small miners are being squeezed out of the exploration and mining business by the mandatory requirements for bonding. (Bonds are 
HONORABLE CHIC HECHT - SEPTEMBER 9, 1986 - PAGE 2.

usually not available for small miner projects. Thus, cash is required.) By way of contrast, our experience has shown that should the land remain under BLM jurisdiction, Mr. Cavanaugh can expect more knowledgeable management of the mineral resources both for exploration and production. BLM has a much larger staff of minerals experts and over the years has demonstrated a better understanding of the land management problems associated with mining on the public domain. BLM annually spends much more on minerals management than does the Forest Service.

We understand your office has been (or will be) contacted by other mining and ranching interests, which are, likewise, concerned about transfer of BLM Iands to the Forest Service.

During the Nevada hearings on the original nation-wide land-swap bill, the pro-Forest Service enthusiasts completely dominated and steam rollered the testimony and the media on this matter - even to the point of defaming BLM's management abilities.

The Nevada Mining Association recognizes that BLM is equally capable of managing the public lands - and in the instance of minerals, a more skilled and helpful agency.

We seek your support to oppose these land transfers which will create hardships for the mining and ranching industries.

Cordially,

Robert E. Warren

REW:V

Enclosure: Map

cc: Senator Paul Laxalt and Nevada Staff

Congressmn Barbara F. Vucanovich and Nevada Staff

NMA Board of Directors

NMA Gold and Silver Operations

Nevada Department of Minerals

Nevada Commission on Mineral Resources

NevadaAssemblyman Joseph Dini

Nevada Cattlemen's Association

Mr. E. A. Hollingsworth

Mr. M. Douglas Miller

Mr. Wallace J. Cavanaugh

with enclosure: Map 


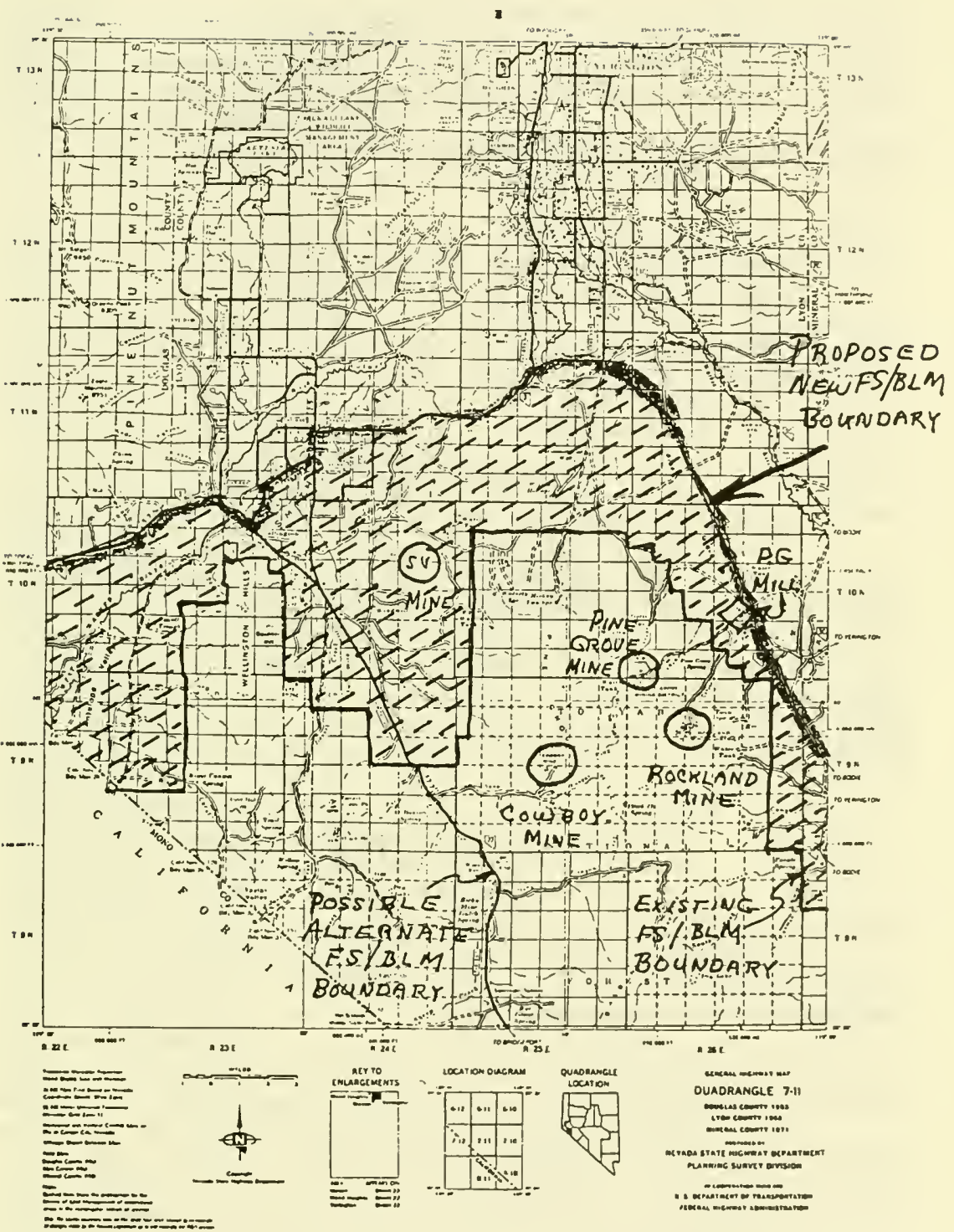


Attachment No. 4

S. 59 Lands Hearing

PINE GROVE HILLS QUADRANGLE

NEVADA - LYON CO

15 MINUTE SERIES (TOPOGRAPHIC)

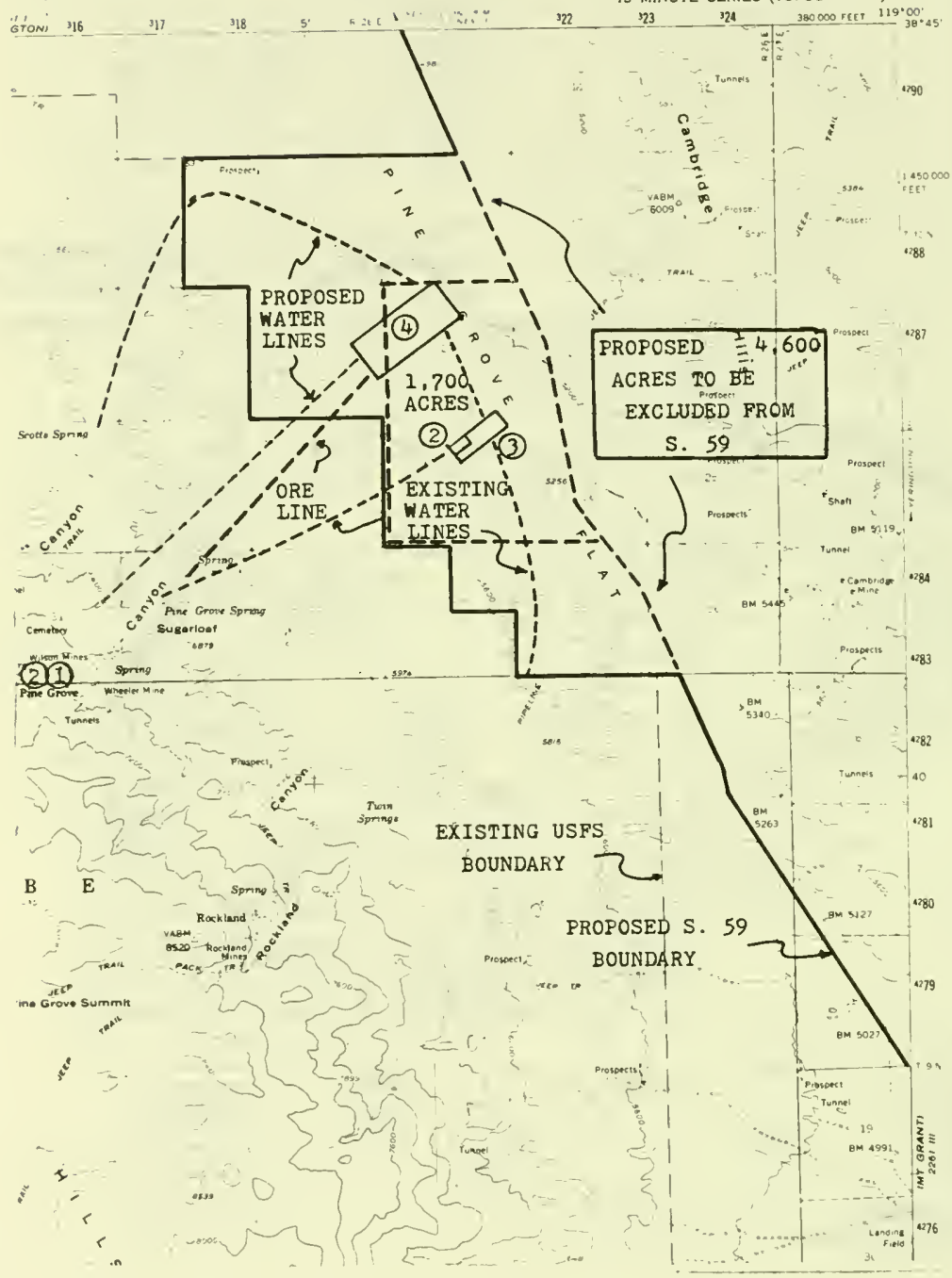


Senator Hecht. Thank you for coming out and testifying. Just a couple of questions for Mr. Clark.

During the testimony, it has been alleged that Nevada lands have been undervalued. Please describe the process used to arrive at their appraisal for this bill.

Mr. Clark. Yes, sir. We met with the Reno office of the Bureau of Land Management and had identified with them the land we have an interest in.

They told us effectively they did not have a budget to do the appraisals, but they did give us a list of appraisers who had been acceptable to them, and gave us a list of appraisal instructions.

We hired a company on that list, gave them the appraisal instructions and paid his bill. He did his appraisal, which was provided to us, and we subsequently, like immediately, that is, provided it to the Bureau of Land Management.

Senator Hecht. Was it MAI appraiser?

Mr. Clark. Yes, sir, it was. In fact, it was a former appraiser for the Bureau of Land Management.

Senator Неснт. And the same way in Florida. MAI, right?

Mr. Clakk. I beg your pardon?

Senator Hеснт. In Florida, you had an MAI

Mr. Clark. Actually, we had two appraisers in Florida. In fact, the same two that we looked at in Nevada.

But the practical matter is, the State of Florida determined the price in Florida, and our appraisers judgment did not matter to them. They knew what they were willing to pay.

Senator Hеснт. Who was higher? The State of Florida, or your appraisers?

Mr. Clark. We were higher.

Senator Hechт. Your appraisers were higher?

Mr. Clark. Yes, they were.

Senator Hecht. How about in Nevada?

Mr. Clark. In Nevada we hired two appraisers. I mentioned the one who was acceptable to the Bureau of Land Management.

The other one was a large national company called Landour. We hired them actually for our own purposes to look for verification, and their prices were nearly the same. Very close.

Senator Hecht. Okay. I assume that you are aware of the land adjacent to the exchange area known as the Butler Ranch. I understand the Butler Ranch was sold for $\$ 401.79$ an acre.

Can you address the discrepancy between this price and the value set on the Coyote Spring Valley land?

Mr. Clark. Yes, sir. I can certainly try to. The Butler Ranch $\$ 400$ price was brought to my attention a few months ago.

At that time I contacted the party who had purchased it and explained that we had an appraisal on the Coyote Spring Valley property of $\$ 45$ an acre, and said, if you do not mind, why do you not tell me why you paid $\$ 400$ for it.

I got a letter from him a few days later that identified his reasoning. I think I am quite sure that that data has been made available to the committee under separate cover, Senator.

Senator Hechт. What basically was his reason?

Mr. Clark. His reason was it had a lighted runway on it. I have seen photographs of the site within the last month or so and I did 
not see any lights. I do not know if they are there or not. Others have said they are not there.

He said it was 85 percent farmable. I believe there is fair proof that that is true. He states that there is a well on the property. He states that there are some running springs on the property. And he also states that there are vested water rights that go with that roughly 560 acres of land.

I quite frankly did not go any further in my own personal investigations. But I did contact a real estate appraiser in Reno, and one in Las Vegas. Once again, described what I will say is this discrepancy.

And I have a letter from each of them that I will be glad to submit in testimony that says that in their judgment there cannot be a valid comparison between the Butler Ranch and the Coyote Spring Valley property that are involved in the land exchange. The size differences alone, in their judgment, are far too big.

Separately, another document that I hope to be able to submit to the committee, I would think, within a week is an actual appraisal from the Butler Ranch, of the Butler Ranch property.

I have a verbal report now by an appraiser who says he thinks it was worth $\$ 400$ when they paid $\$ 400$ for it. He also said, he does not think that has anything to do with our property.

Senator Hecht. And you say there is a runway on the property. Mr. Clark. Yes, sir. But it looked like, his letter said there is a lighted runway.

I saw a photograph of the site, an aerial photograph, and it looks to me like what it is is somebody took a bulldozer with a blade or a scraper and scraped off the dirt. It sure did not look like it was paved or anything of the kind. If there were lights, I did not see them.

Senator Неснт. One other point that I think you ought to have a chance to repudiate or agree to are references made to your company's activities in California and the Superfund issue out there.

Would you care to comment on this?

Mr. Clark. Yes, I very much would, as a matter of fact. There is contamination in the ground water and and near our Sacramento site.

It was identified in 1979. Since that time my corporation has spent roughly $\$ 39$ million to clean that up. There has not been one single penny of Superfund money spent there.

We are in negotiations, and very near reaching a consent order with the various Federal and state agencies. I think we have acted in a very responsible manner in correcting problems that existed because of generally accepted practices and people in business such as ours.

You will find a number of sites in the Sacramento area, which have very similar problems to ours, and they are not rocket motor producers like me. They are other installations.

I believe we have been quite responsible.

Senator Hecht. Okay. It is 5 p.m. and that is the witching hour here. So we got in under the wire.

I want to thank everyone for coming out. The record will be open for two weeks. If you get home and you decide you want to put 
something in the record in addition to what you have spoken about, feel free. It will be put in at the proper spot.

The hearing is adjourned.

[Whereupon, at 5 p.m., the hearing was adjourned.]

[COMMITTEE NOTE.-Due to the voluminous nature of materials submitted for the record all additional statements and letters have been retained in subcommittee files.] 







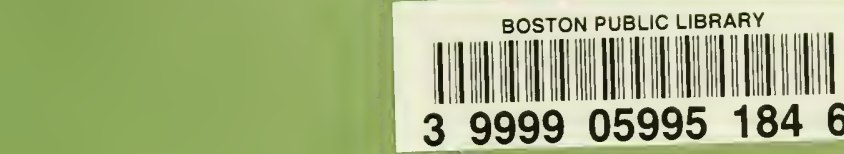
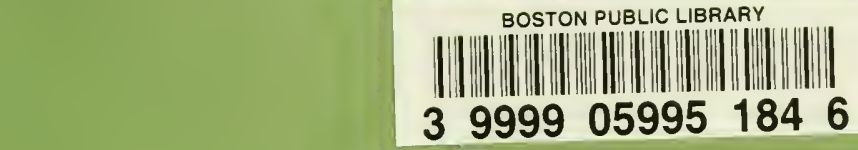

.

\section{3}


